Juliê Rosemberg Sartoretto

\title{
Histórico de Atividade Antrópica no Sistema Estuarino Santos e São Vicente
}

Dissertação apresentada ao Instituto Oceanográfico da Universidade de São Paulo, como parte dos requisitos para obtenção do título de Mestre em Ciências, área de Oceanografia Química.

Orientador: Prof. Dr. Rubens Cesar Lopes Figueira 
Universidade de São Paulo

Instituto Oceanográfico

Histórico de Atividade Antrópica no Sistema Estuarino

Santos e São Vicente

Versão corrigida

Juliê Rosemberg Sartoretto

Dissertação apresentada ao Instituto Oceanográfico da Universidade de São Paulo como parte dos requisitos para obtenção do título de Mestre em Ciências, Programa de Oceanografia, área de Oceanografia Química

Julgada em ____________

Prof(a). Dr(a).

Conceito

Prof(a). Dr(a).

Conceito

Prof(a). Dr(a).

Conceito 


\section{Sumário}

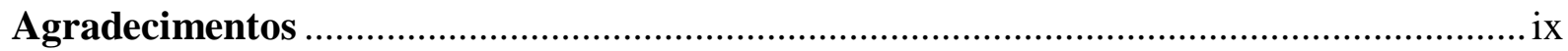

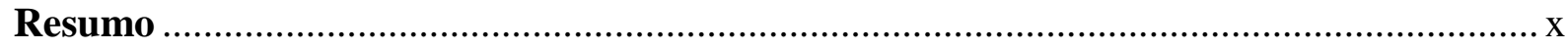

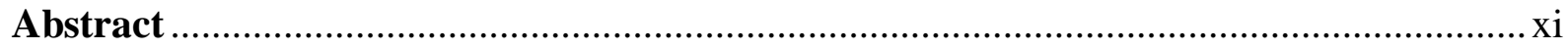

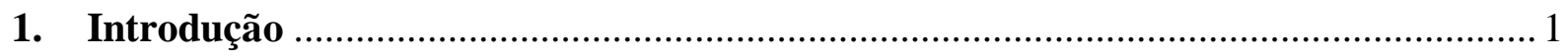

1.1. A Ocupação da zona litorânea e influência antrópica em estuários ........................... 1

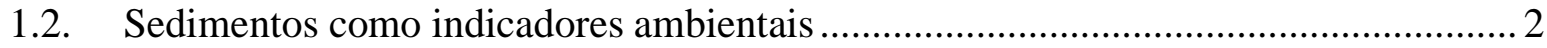

1.3. Contaminação por metais em estuários ..................................................................... 3

1.4. A Situação da Baixada Santista ................................................................................... 5

1.5. Estudos anteriores de metais pesados na região de Santos ...................................... 8

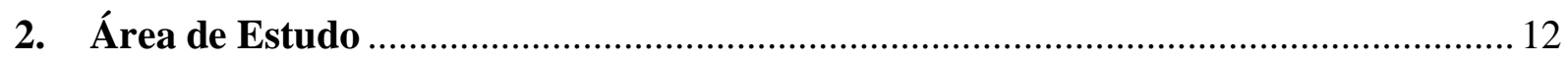

2.1. Hidrodinâmica e sedimentação no Estuário de Santos e São Vicente........................ 13

2.2. Hidrodinâmica e sedimentação do Canal de Bertioga ............................................. 15

3. Objetivos .................................................................................................................................................... 17

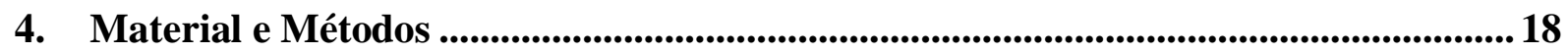

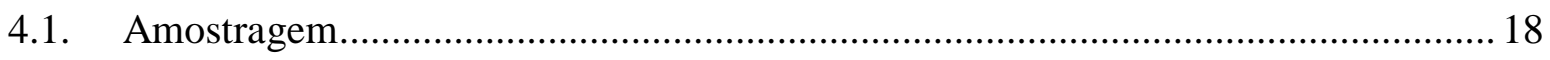

4.2. Datação dos testemunhos e cálculo da Taxa de Sedimentação ................................. 19

4.3. Análise granulométrica de sedimentos finos .......................................................... 19

4.4. Análise da Variação da Suscetibilidade Magnética.................................................. 20

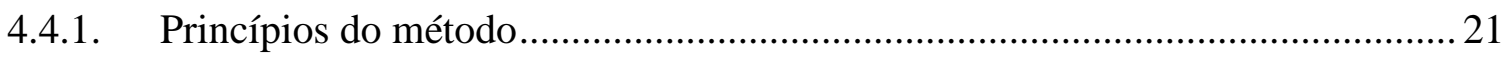

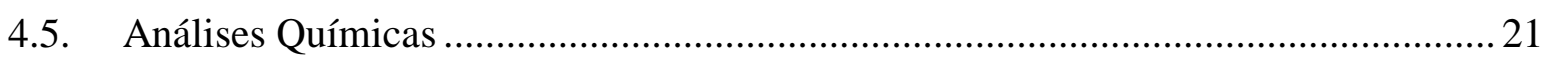

4.5.1. Digestão parcial de sedimento para a análise de metais e semimetais ............... 21

4.5.2. Determinação de mercúrio $(\mathrm{Hg})$ por geração de vapor ....................................... 22

4.5.3. Digestão total dos sedimentos da base dos testemunhos.................................. 23

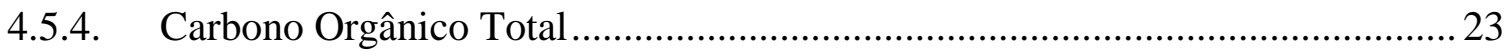

4.5.5. Limites de detecção do equipamento (LDE) ................................................. 24

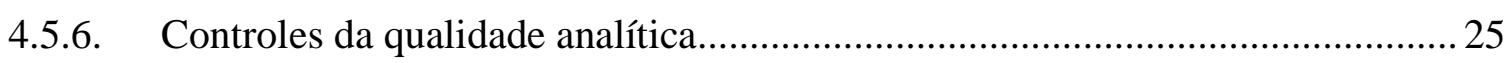

4.6. Avaliação dos níveis de metais por índices e parâmetros de poluição ...................... 26

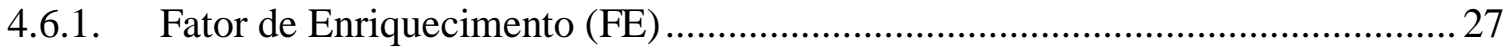

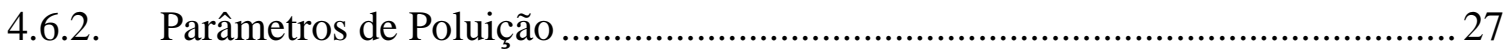


5. Análise de Resultados e Discussão Preliminar .................................................................. 30

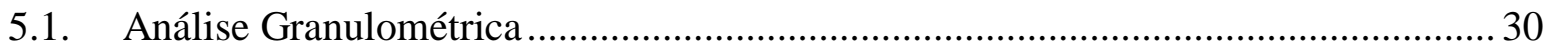

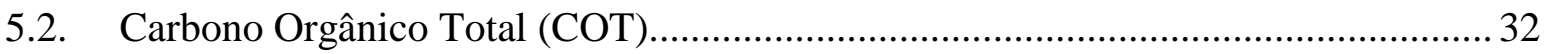

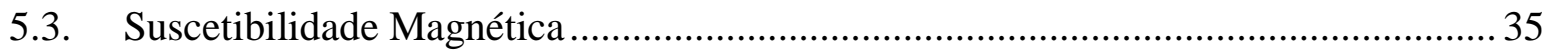

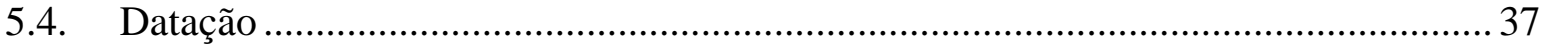

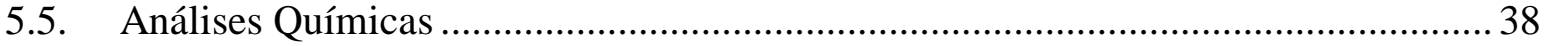

5.5.1. Digestão parcial de sedimento para a análise de metais e semimetais ............... 38

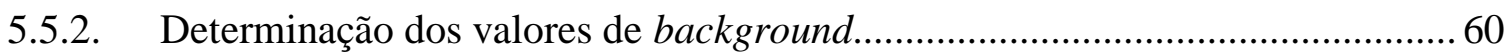

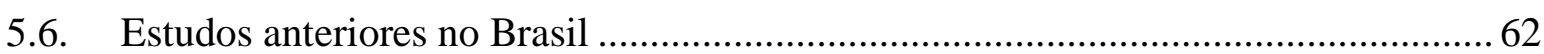

6. Discussão: reconstrução histórica a partir de testemunhos ........................................ 65

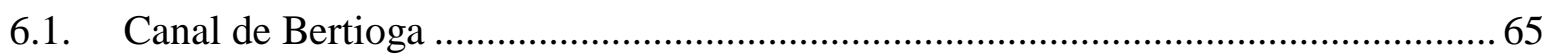

6.1.1. Arsênio e metais contaminantes no Canal de Bertioga ....................................... 65

6.1.2. A análise de contaminação dos sedimentos como reflexo do histórico ambiental

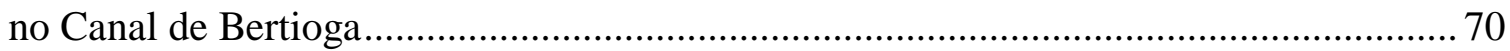

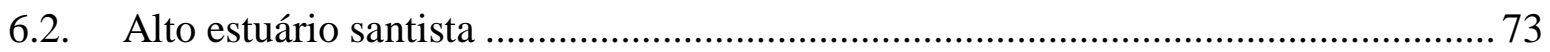

6.2.1. Metais contaminantes no alto estuário santista ............................................. 73

6.2.2. A análise de contaminação dos sedimentos como reflexo do histórico ambiental

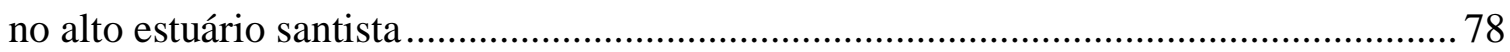

7. Considerações Finais e Conclusão .................................................................... 85

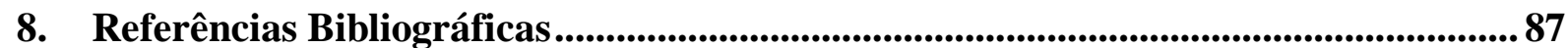

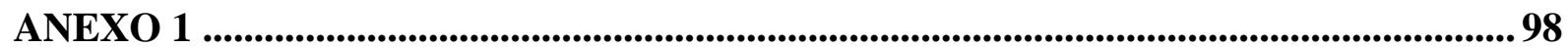

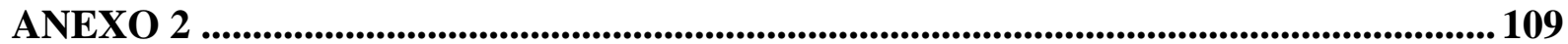

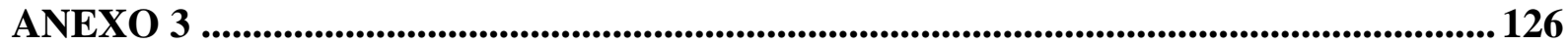




\section{Índice de Figuras}

Figura 1. Localização das indústrias e terminais da Baixada Santista em 1999. Fonte: Cetesb, 2001.

Figura 2. Localização das fontes de poluição associadas ao saneamento básico na Baixada Santista em 1999. Fonte: Cetesb, 2001.

Figura 3. Sistema Estuarino Santos-São Vicente.

Figura 4. Esquema geral da circulação no interior do Canal de Santos. (modificada de Kutner, 1976). 14

Figura 5. Localização dos testemunhos coletados ao longo do Estuário Santos e São Vicente.

Figura 6. Teores de sedimentos finos nos testemunhos localizados no Canal de Bertioga .... 31

Figura 7. Teores de sedimentos finos nos testemunhos localizados em Santos. 32

Figura 8. Valores de Carbono Orgânico Total (COT) para os testemunhos localizados no Canal de Bertioga. .33

Figura 9. Valores de Carbono Orgânico Total (COT) para os testemunhos localizados em Santos. 34

Figura 10. Perfil de Susceptibilidade Magnética para os testemunhos de Bertioga. 36

Figura 11. Perfil de Susceptibilidade Magnética para os testemunhos de Santos. 37

Figura 12. Valores de concentração de As $(\mathrm{mg} / \mathrm{kg})$ para os testemunhos localizados no Canal de Bertioga.

Figura 13. Valores de concentração de As $(\mathrm{mg} / \mathrm{kg})$ para os testemunhos localizados em Santos. .43

Figura 14. Valores de concentração de $\mathrm{Cr}(\mathrm{mg} / \mathrm{kg})$ para os testemunhos localizados no Canal de Bertioga. .45

Figura 15. Valores de concentração de $\mathrm{Cr}(\mathrm{mg} / \mathrm{kg})$ para os testemunhos localizados em Santos. 46

Figura 16. Valores de concentração de $\mathrm{Cu}(\mathrm{mg} / \mathrm{kg})$ para os testemunhos localizados no Canal de Bertioga. 47

Figura 17. Valores de concentração de $\mathrm{Cu}(\mathrm{mg} / \mathrm{kg})$ para os testemunhos localizados em Santos. .49 
Figura 18. Valores de concentração de $\mathrm{Hg}(\mathrm{mg} / \mathrm{kg})$ para os testemunhos localizados no Canal de Bertioga.

Figura 19. Valores de concentração de $\mathrm{Hg}(\mathrm{mg} / \mathrm{kg})$ para os testemunhos localizados em Santos. .52

Figura 20. Valores de concentração de $\mathrm{Ni}(\mathrm{mg} / \mathrm{kg})$ para os testemunhos localizados no Canal de Bertioga. .54

Figura 21. Valores de concentração de $\mathrm{Ni}(\mathrm{mg} / \mathrm{kg})$ para os testemunhos localizados em Santos. .55

Figura 22. Valores de concentração de $\mathrm{Pb}(\mathrm{mg} / \mathrm{kg})$ para os testemunhos localizados no Canal de Bertioga. 56

Figura 23. Valores de concentração de $\mathrm{Pb}(\mathrm{mg} / \mathrm{kg})$ para os testemunhos localizados em Santos. .57

Figura 24.Valores de concentração de $\mathrm{Zn}(\mathrm{mg} / \mathrm{kg})$ para os testemunhos localizados no Canal de Bertioga. .58

Figura 25. Valores de concentração de $\mathrm{Zn}(\mathrm{mg} / \mathrm{kg})$ para os testemunhos localizados em Santos. .59

Figura 26. Perfis de fator de enriquecimento para As nos testemunhos Bertioga 2, 3, 4 e $5 . .66$

Figura 27. Perfis de fator de enriquecimento para $\mathrm{Cu}$ nos testemunhos Bertioga 2, 3 e $5 . \ldots 67$

Figura 28. Perfis de fator de enriquecimento para $\mathrm{Pb}$ nos testemunhos Bertioga 2, 3 e 5..... 68

Figura 29. Perfis de fator de enriquecimento para $\mathrm{Zn}$ nos testemunhos Bertioga 2, 3 e $5 \ldots . . .69$

Figura 30. Perfis de fator de enriquecimento para $\mathrm{Hg}$ nos testemunhos Bertioga 2, 3 e $5 . . .70$

Figura 31. Valores de PLI para o testemunho Bertioga 5 ................................................ 71

Figura 32. Valores de RI para os testemunhos Bertioga 2, 4 e 5 ...................................... 72

Figura 33. Perfis de fator de enriquecimento para $\mathrm{Cu}$ nos testemunhos Santos 1, 2 e 8........ 74

Figura 34. Perfis de fator de enriquecimento para $\mathrm{Pb}$ nos testemunhos Santos 1,2 e 8........ 75

Figura 35. Perfis de fator de enriquecimento para $\mathrm{Hg}$ nos testemunhos Santos 1,2 e 8....... 77

Figura 36. Perfis de fator de enriquecimento para $\mathrm{Zn}$ nos testemunhos Santos 1,2 e 8........ 78

Figura 37. Valores de PLI para os testemunhos Santos 2 e Santos 8.................................... 79

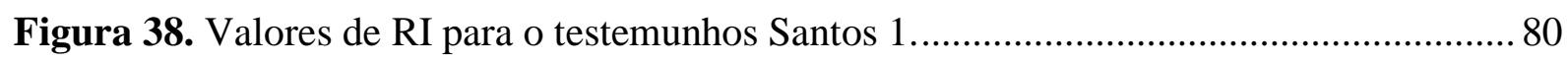

Figura 39. Imagens históricas da região a qual está inserida o testemunho Santos 1 ............ 80

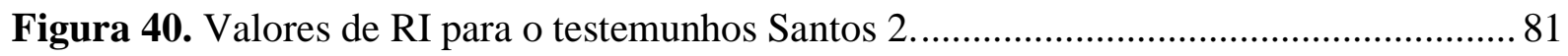

Figura 41. Imagens históricas da região a qual está inserida o testemunho Santos 2 ............ 82

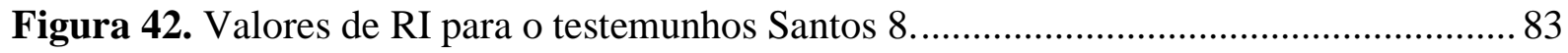


Figura 43. Imagens históricas da região a qual está inserida o testemunho Santos 8 . 84 


\section{Índice de Tabelas}

Tabela 1. Coordenadas e comprimento aproximado dos testemunhos coletados no Canal de Bertioga.

Tabela 2. Valores de limite de detecção para os metais analisados.

Tabela 3. Resultados do material de referência certificado SS-1. 25

Tabela 4. Resultados do material de referência certificado SS-2. .26

Tabela 5. Taxas de sedimentação baseadas no modelo CIC para os testemunhos estudados. 38

Tabela 6. Valores de concentração orientadores $(\mathrm{em} \mathrm{mg} / \mathrm{kg}$ ) para metais e As. 39

Tabela 7. Valores de concentração para amostras da base dos testemunhos, localizados no Canal de Bertioga, analisados a partir da digestão total do sedimento.

Tabela 8. Valores de concentração para amostras da base dos testemunhos, localizados em

Santos, analisados a partir da digestão total do sedimento. 62

Tabela 9. Valores máximos e mínimos de As e metais $(\mathrm{mg} / \mathrm{kg})$ em diferentes estudos e regiões do Brasil 


\section{Agradecimentos}

Agradeço primeiramente a Deus, por ter me dado saúde e seguir me iluminando.

Ao meu orientador Prof. Dr. Rubens Cesar Lopes Figueira pela paciência, dedicação de sempre, e principalmente pela oportunidade de mais uma parceria.

À minha família: meus pais e meu irmão que me ensinam todos os dias a não desistir dos meus sonhos e o significado do amor incondicional. Obrigada pela paciência e apoio nas fases difíceis.

Ao Felipe, por estar ao meu lado em todos os momentos e escolhas da minha vida. Obrigada por me fazer acreditar que tudo é possível.

À minha Vózinha querida, que me é motivo de inspiração. Obrigada por todas as rezas, palavras carinhosas e ensinamentos. A senhora é o amor da minha vida!

Aos meus colegas de laboratório, que tornaram meus dias mais divertidos. Agradeço as parcerias que se formaram e o companheirismo que vai de almoços a problemas com o ICP.

Aos amigos, que me aguentam nos momentos de nervosismo com paciênciae doses de ânimo: Bianca, Edgar, Carolzinha, Flávia, Dé, Dante e Borelli.

Agradeço todos da CPEA, que me deram força durante todo o último ano: Cristina, Clarice, Daniel, Edson, Fabinho e Viviane.

Ao Conselho Nacional de Desenvolvimento Científico e Tecnológico pelo suporte fornecido durante o período de execução deste trabalho.

A todos os professores que permitiam que meu sonho se realizasse e que fizeram crescer o meu amor por essa profissão.

Agradeço todos os funcionários do IO, que gentilmente sempre me auxiliaram, em especial as meninas da Secretaria de Pós Graduação, que sempre me atenderam com paciência e gentileza. 


\section{Resumo}

A Baixada Santista é um dos locais mais amplamente povoados e explorados do estado de São Paulo. Nas últimas décadas, devido à intensa industrialização, a Baixada Santista vem sofrendo um acentuado processo de degradação ambiental. Deste contexto, os metais se apresentam de suma importância, podendo refletir a influência do homem no meio ambiente. O presente trabalho tem como principal objetivo a reconstrução ambiental do Estuário de Santos e São Vicente no âmbito da poluição da região, avaliada a partir da análise de metais no sedimento. Para isso, foram analisados nove testemunhos, que permitiram uma visão histórica do reflexo da antropização nesse ambiente costeiro. Distinguiram-se a partir dos resultados dois ambientes distintos: Canal de Bertioga e Alto Estuário Santista. Os testemunhos localizados no Canal de Bertioga apresentaram acúmulos metais mais recentes de metais, com destaque para $\mathrm{As}, \mathrm{Cu}, \mathrm{Pb}, \mathrm{Zn}$ e $\mathrm{Hg}$. Os aumentos significativos de concentração nesse ambiente, possivelmente estiveram associados a alguns acidentes ambientais, como o incêndio na Vila de Socó, na década de 1980. Os testemunhos localizados no Alto Estuário Santista apresentaram concentrações elevadas de alguns metais, como é o caso de $\mathrm{Cu}, \mathrm{Pb}, \mathrm{Zn}$ e $\mathrm{Hg}$. Destacaram-se os valores de $\mathrm{Hg}$, que indicaram ambientes contaminados. A concentração de metais nessa região foi coerente com o crescimento industrial e urbano da região.

Palavras chave: metais; Canal de Bertioga; Alto Estuário Santista; testemunhos; contaminação; ICP-OES 


\begin{abstract}
The Baixada Santista is an important economic region of Sao Paulo State, strongly urbanized and populated, where environmental pressures are increasing due to the local industrialization development. As heavy metal concentrations may indicate human influences in the environment, this study aimed to reconstruct the spatial and temporal trends of pollution in Santos e São Vicente through the last decades, using the concentration of heavy metals and As from nine sliced sediment cores analyzed with ICP-OES. The results pointed two regions of distinct chemical patterns: Bertioga Channel and Santos Estuary. The former presented recent accumulations, mainly of $\mathrm{As}, \mathrm{Cu}, \mathrm{Pb}, \mathrm{Zn}$ and $\mathrm{Hg}$, possibly due to environmental incidents as the Vila Socó fire in the 1980s. The latter presented high concentrations of $\mathrm{Cu}$, $\mathrm{Pb}, \mathrm{Zn}$ and especially $\mathrm{Hg}$, indicating contamination in this region. The concentration of metals in the study area was consistent with the local industrial growth.
\end{abstract}

Key words: metals; Bertioga Channel; Santos Estuary; sediment cores; contamination; ICPOES 


\section{Introdução}

\subsection{A Ocupação da zona litorânea e influência antrópica em estuários}

Historicamente a atratividade das regiões costeiras condicionou o estabelecimento das primeiras aglomerações humanas nessas áreas, as quais evoluíram em geral de maneira não planejada. Segundo Oliveira (2009), estas aglomerações levaram a formação de grandes metrópoles regionais e mundiais, estabelecendo condições de grande demanda dos recursos naturais. Este processo faz com que estes ambientes tornem-se locais estratégicos para o desenvolvimento ocupacional e de atividades industriais. No entanto, a utilização inadequada de tais recursos tem gerado alterações no equilíbrio desses ecossistemas, comprometendo o ciclo natural dos seus componentes e aumentando sua vulnerabilidade.

No ambiente costeiro, os estuários desempenham ainda papel fundamental no ciclo hidrológico, sendo responsáveis pela ligação entre o ambiente terrestre e oceânico além de controlar a transferência dos contaminantes presentes na drenagem continental para as águas marinhas. São ecossistemas complexos e extremamente dinâmicos devido aos expressivos gradientes de salinidade, $\mathrm{pH}$, variações nas propriedades químicas da água, grandes variações de material em suspensão e inúmeros processos hidrodinâmicos controlados por marés, ventos e ondas. Ocupando a área de interface terra-mar, os estuários são, muitas vezes, a conexão mais importante na transferência de materiais para o oceano (Solomons e Forstner, 1984).

Sob o ponto de vista ambiental, as regiões estuarinas contribuem na disponibilização de grande diversidade de ambientes potencialmente disponíveis para colonização, refúgio e criadouro de espécies economicamente importantes. Em consequência desta intrínseca diversidade, possuem uma complexa trama trófica, com energia suficiente para sustentar os grandes ambientes costeiros. Devido à forte ocupação das áreas litorâneas, regiões estuarinas são receptáculos de substâncias e produtos antrópicos, os quais podem ocasionar a degradação da qualidade da água (Knoppers et al., 1999).

Neste âmbito, a introdução direta ou indireta de substâncias e de energia pelo homem podem atingir níveis de concentração que causam a contaminação do estuário, com efeitos nocivos aos recursos vivos, riscos à saúde humana, obstáculos para as atividades marinhas e de pesca, deterioração da qualidade da água e redução de seus atrativos naturais. Uma importante função da região estuarina consiste ainda na formação de barreiras biogeoquímicas 
ao transporte de metais pesados, sendo que as propriedades de retenção destes compostos podem ser afetadas por atividades naturais ou antropogênicas, contribuindo para a complexidade do sistema (Gesamp, 1995).

Aproximadamente dois terços da humanidade habitam zonas costeiras, sendo que a maior parte das metrópoles contemporâneas situa-se próximo aos mares. Os litorais abrigam, portanto, um contingente populacional elevado que apresenta grande concentração de atividades industriais e domésticas, as quais produzem elevados volumes de dejetos por unidade de tempo. O perfil concentrado da ocupação costeira emerge, portanto, como uma preocupação comum às civilizações atuais e reforça a necessidade imediata de evolução no conhecimento científico que contribua para ações efetivas de preservação, monitoramento e remediação de áreas impactadas.

\subsection{Sedimentos como indicadores ambientais}

De acordo com Lacerda et al. (1994), os metais podem atingir os ecossistemas aquáticos por fontes diversas como, por exemplo, do resultado do intemperismo de rochas constituintes da bacia hidrográfica, do escoamento superficial de áreas agrícolas e urbanas, de águas subterrâneas contaminadas, da remobilização sedimentar, da disposição de material dragado e deposição atmosférica e de fontes pontuais como descargas de efluentes industriais e urbanos. A descarga fluvial é a principal transportadora de metais de origem continental para as áreas costeiras, estabelecendo uma relação essencial para o conhecimento das variações geoquímicas no ambiente.

Quando em contato com as águas dos rios, os metais são carreados para as regiões costeiras na fase dissolvida ou associados ao material particulado em suspensão. Ao atingir o ambiente marinho, grande parte do material particulado em suspensão presente nas águas dos rios é depositada nos sedimentos fazendo com que as áreas costeiras atuem como barreiras geoquímicas ao transporte de metais para o oceano (Lacerda, 1994; Cardoso et al., 2001). Desta forma, os sedimentos têm sido amplamente utilizados como indicadores ambientais, porque possuem grande capacidade de incorporar e acumular elementos contaminantes. Neste contexto, como os sedimentos são levados pelos rios para outro curso de água ou para o mar, as análises dos sedimentos em vários pontos de uma região de interesse servem para rastrear 
fontes de contaminação, além de tornar possível nortear o monitoramento destas substâncias em áreas de controle (Pereira et al, 1998).

A ocorrência de variações nas características físicas e químicas do meio (como pH, salinidade, conteúdo de compostos orgânicos, entre outras) pode liberar um poluente incorporado ao sedimento, implicando que mudanças nas condições ambientais e dragagens podem transformar os sedimentos em fontes de contaminação (Soares et al., 1999). Ao refletirem a qualidade do sistema e o desenvolvimento histórico de parâmetros hidrológicos e químicos (Salomons e Förstner, 1984) são particularmente úteis na identificação, monitoramento e no controle de fontes de poluição.

\subsection{Contaminação por metais em estuários}

A análise de sedimento de testemunhos é de suma importância na avaliação histórica de poluentes. Os sedimentos funcionam como indicadores a longo e médio prazo do fluxo de metais em ambientes industrializados, ajudam a melhorar as estratégias de gestão, assim como são eficientes para avaliar o sucesso dos controles recentes de poluição. O estudo de colunas sedimentares fornece o registro histórico da acumulação de metais no sistema aquático, indicando tanto os níveis de basais de metais como fontes antrópicas (Ravichandran et al., 1995).

Mahiques et al. (2013) analisaram as concentrações de $\mathrm{Cr}, \mathrm{Cu}, \mathrm{Pb}$ e $\mathrm{Zn}$ em quatro testemunhos coletados no sistema estuarino lagunar Cananéia-Iguape (São Paulo), visando determinar as propriedades químicas da coluna sedimentar. As concentrações encontradas de $\mathrm{Pb}$ indicaram valores superiores que os sedimentos da Baixada Santista, concluindo que a entrada de metais pesados na região, principalmente o chumbo, foram associados com a atividades mineradoras atuaram na região do Rio Ribeira de 1945 até 1995, e que a entrada desses elementos pode ocorrer devido ao desgaste das pilhas de resíduos armazenadas nas áreas marginais locais.

Carvalho Gomes et al. (2009) analisaram os metais Cd, Cr, Ga, K, Mn, Rb, Sr Ti, V e Zn em quatro testemunhos localizados na Baía do Ribeira e três na Baía de Sepetiba, Rio de Janeiro. Os autores buscaram uma comparação entre os resultados obtidos nos dois ambientes. Concluiu-se que as baías em questão apresentaram valores semelhantes para a maioria dos metais, sugerindo uma fonte semelhante desses para os sedimentos. Os elementos $\mathrm{Cd}$ e $\mathrm{Zn}$ apresentaram teores característicos de regiões contaminadas. Na Baía de Sepetiba, os valores 
de Cd alcançaram valores próximos a $5,0 \mathrm{mg} / \mathrm{kg}$, já Zn atingiu concentrações máximas em torno de $800 \mathrm{mg} / \mathrm{kg}$. Assim como a Baixada Santista, a Baía de Sepetiba sofreu grandes alterações ambientais devido ao crescimento industrial e urbano desenfreado. Os valores de metais nessa região são superiores aos encontrados na Baixada Santista.

Kumar e Edward (2008) avaliaram Cd, Cr, Cu, Ni, Co, Pb e Zn em três testemunhos localizados no estuário de Manukady, costa sudoeste da Índia. Foram estudadas as concentrações dos elementos citados, assim como os índices Igeo (Índice de geoacumulação), Fator de Concentração e Pollution Load Index (PLI). De maneira geral, os valores apresentados indicaram sedimentos com uma boa qualidade ambiental, com poucos pontos característicos de uma contaminação moderada. A concentração dos metais foram inferiores às encontradas na Baixada Santista.

Borges et al. (2007) analisaram $\mathrm{Fe}, \mathrm{Cu}$ e $\mathrm{Pb}$ em três testemunhos em regiões de mangue na Baia de Guanabara. Um dos testemunhos se localizava em uma região onde a vegetação havia sido desmatada há 20 anos, a segunda onde a vegetação havia sido desmatada há dois anos e a terceira com uma vegetação remanescente. As concentrações obtidas de $\mathrm{Cu}$ e $\mathrm{Pb}$ foram superiores àquelas apresentadas na Baixada Santista. Relaciona-se esse aporte a crescente influência industrial na região, somada à degradação do manguezal, que acaba por afetar a origem da matéria orgânica nos sedimentos.

Liu et al. (2003) estudaram $\mathrm{Co}, \mathrm{Cu}, \mathrm{Ni}, \mathrm{Pb}$ e $\mathrm{Zn}$ em 19 testemunhos localizados no Estuário do Rio Pearl, China. Todos os metais estudados apresentaram concentrações superiores às observadas na Baixada Santista. Devido ao processo de industrialização acelerado e muitas vezes descontrolado, a China enfrenta hoje diversos problemas ambientais. No estudo em questão, observou-se um aumento na concentração dos metais nos 20 anos anteriores ao estudo. Os maiores valores foram observados para $\mathrm{Cu}$ e $\mathrm{Zn}$, que puderam ser justificados pela industrialização da região.

Tanner et al. (2000) pesquisaram os metais: $\mathrm{Cr}, \mathrm{Cu}, \mathrm{Mn}, \mathrm{Ni}, \mathrm{Pb}, \mathrm{Zn}$ em cinco testemunhos de Hong Kong, China. As amostras foram analisadas em um ICP-AES. Assim como o estuário santista, encontra-se na área de estudo uma grande região portuária. A influência da industrialização e do porto no meio ambiente é claramente notada na análise de metais. $\mathrm{O}$ poluente mais crítico foi o $\mathrm{Cu}$, que apresentou valores de fator de enriquecimento entre 2,8 e 312 em sedimentos localizados em Typhoon Shelter, valores estes muito superiores aos encontrados na Baixada Santista. Observou-se, de maneira geral, poluições de $\mathrm{Cu}$, Ni e Cr datadas do período pós-industrial (após 1950), já os elemetos Zb e Pb apresentam 
contaminações mais antigas, justificadas pelo histórico de construção, manutenção e ancoragens de navios na região.

\subsection{A Situação da Baixada Santista}

O litoral paulista desde os primórdios da ocupação foi um dos locais mais amplamente povoados e explorados do estado. A Baixada Santista, que compreende o espaço costeiro delimitado politicamente entre os municípios de Bertioga e Praia Grande, é uma das regiões economicamente mais importantes do Brasil. Esta significativa ocupação ocorreu, principalmente, devido ao grande desenvolvimento econômico da região durante o século XX, com melhorias na estrutura portuária de Santos, a implantação do polo petroquímico de Cubatão e a construção de rodovias ligando a capital ao litoral. Como consequência, intensas interferências no ambiente costeiro devido ao despejo de resíduos industriais e os dejetos domésticos geraram mudanças nas áreas estuarinas.

O intenso processo de urbanização e industrialização da Baixada Santista acabou por afetar diretamente seus equilíbrios naturais. O resultado mais notável desse cenário são as mudanças físicas do meio, como a aceleração no uso e ocupação do solo. Nos últimos anos, construções de rodovias, ferrovias e núcleos habitacionais nas encostas da Serra do Mar foram crescentes. Observa-se a eliminação da vegetação em áreas da planície costeira. Reflexos, talvez menos visíveis, dessas mudanças são as alterações das condições químicas das águas superficiais. Lançamentos de resíduos industriais e domésticos alteram, não só a composição das águas, como a deposição de sedimentos finos (Fukumoto, 2007).

A busca pelo avanço tecnológico e desenvolvimento gerou preocupações com o ambiente marinho. Nas últimas décadas, devido à intensa industrialização, a Baixada Santista vem sofrendo um intenso processo de degradação ambiental. O aporte de resíduos de origem natural e antropogênica pode atingir os oceanos através das bacias de drenagem ou pela deposição atmosférica (Lacerda e Marins, 2006). A concentração elevada de metais denota uma preocupação ambiental relevante para a gestão dos ambientes costeiros.

Diversos fatores favoráveis, como a proximidade da região metropolitana de São Paulo e a construção de uma desenvolvida infraestrutura de transporte (rodoviário, ferroviário e portuário) levaram, a partir da década de 50, à implantação de diversas indústrias de base em Cubatão. 
A região contempla: indústrias siderúrgicas com potencial de emissão dos elementos metálicos $\mathrm{Cu}, \mathrm{Mn}, \mathrm{Ni}$, e $\mathrm{Zn}$, refinarias de petróleo com potenciais de emissão de $\mathrm{Cu}, \mathrm{Cr}$, $\mathrm{Ni}$, $\mathrm{Hg}$ e $\mathrm{Zn}$, indústrias químicas e petroquímicas com potenciais de emissão de $\mathrm{Cd}, \mathrm{Cu}, \mathrm{Cr}, \mathrm{Mn}$, $\mathrm{Ni}, \mathrm{Pb}, \mathrm{Zn}$ e $\mathrm{Hg}$ e indústrias de fertilizantes com potenciais de emissão de $\mathrm{Pb}, \mathrm{Ni}$ e $\mathrm{Zn}$. Esta atividade industrial, de alto potencial poluidor, faz do Sistema Estuarino de Santos e São Vicente um grande receptor de metais (Cetesb, 2001). A localização das principais indústrias da região é apresentada na Figura 1.

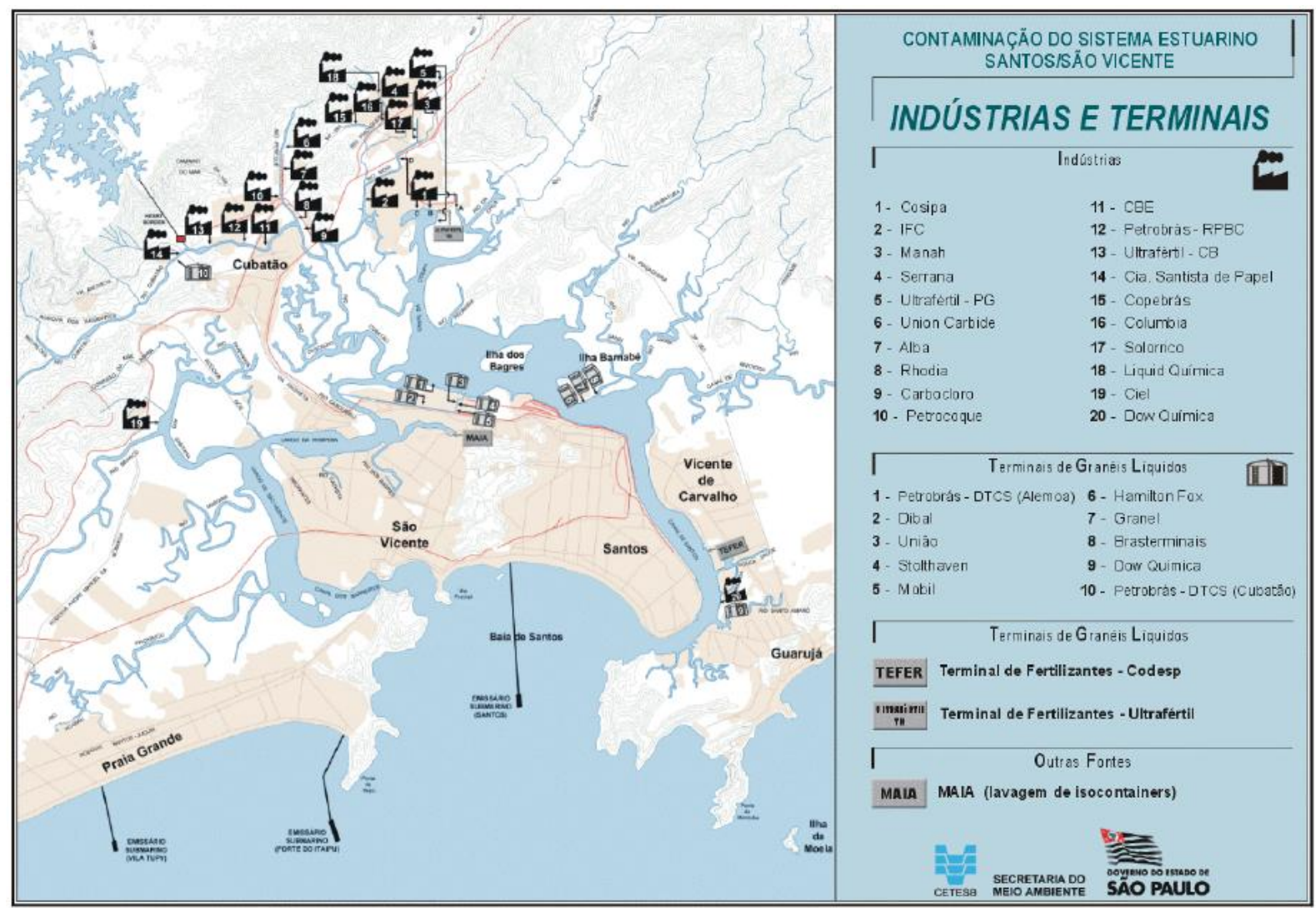

Figura 1. Localização das indústrias e terminais da Baixada Santista em 1999. Fonte: Cetesb, 2001.

Está localizado nesse sistema, o maior porto da América Latina. Possui uma extensão de cerca de $10 \mathrm{~km}$ a partir da Baía de Santos, possui largura entre 200 e $300 \mathrm{~m}$ e profundidade mínima variando de 5 a $14 \mathrm{~m}$. Nas áreas portuárias, possíveis fontes de contaminação estão ligadas ao armazenamento de mercadorias, às operações de limpezas de tanques, lavagens de porões, despejos de navios atracados e as perdas de substâncias nas operações de carga e descarga (Cetesb, 2001). 
Outro problema ambiental decorrente das atividades portuárias é a dragagem. Para permitir o tráfego de navios de grande porte é realizada a dragagem no Canal do Porto e no Canal de Piaçanguera. Segundo a Companhia Docas do Estado de São Paulo (CODESP), nas dragagens de aprofundamento estão previstas em projeto profundidades de até $17 \mathrm{~m}$. A atividade de dragagem e a disposição do material dragado são motivos de discussão, uma vez que podem alterar significativamente tanto o ambiente dragado quanto o local de deposição do sedimento dragado (Fukumoto, 2007).

Importante fonte de contaminação para as águas da região, o sistema de deposição de esgoto de Santos e São Vicente opera desde 1978 à vazão máxima de 7000 L/s (Fukumoto, 2007). O sistema é composto por uma estação de pré-condicionamento (EPC) e um emissário submarino. A maior parte do esgoto doméstico de Santos e São Vicente é lançada ao mar pelo emissário submarino, mas há um aporte de esgoto clandestino e de materiais provenientes de ocupações irregulares ao longo da orla marinha (Abessa, 2002). Os principais locais de despejo de esgoto domésticos podem ser visualizados na Figura 2.

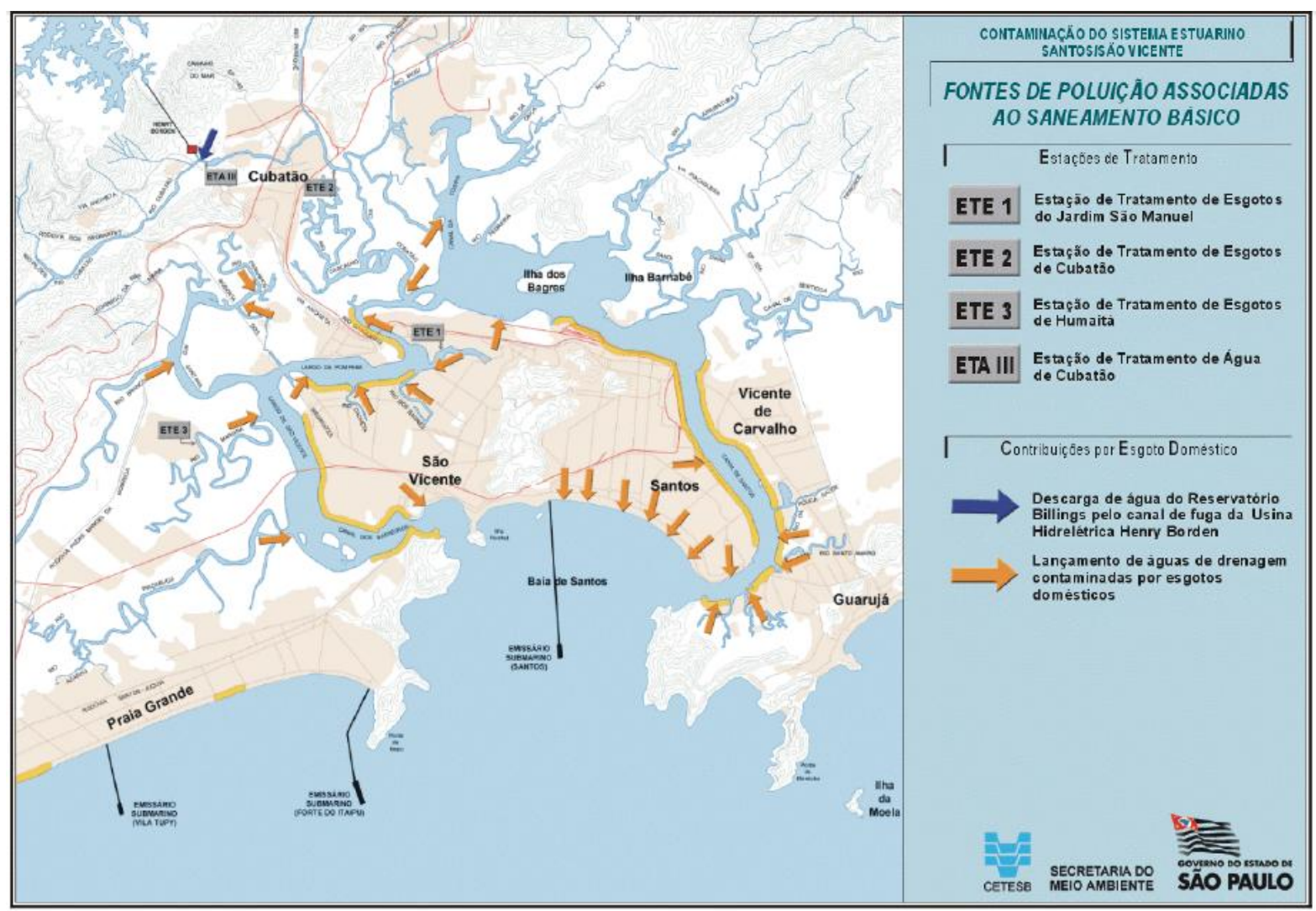

Figura 2. Localização das fontes de poluição associadas ao saneamento básico na Baixada Santista em 1999. Fonte: Cetesb, 2001. 
Estima-se que na Baixada Santista, 75\% do esgoto é coletado, sendo apenas $19 \%$ deste tratado. Quando analisados os municípios separadamente, Santos possui $98 \%$ do seu esgoto coletado, não havendo tratamento para estes. Os principais corpos receptores dessa carga poluidora são a Baía de Santos e o canal de São Jorge. Cubatão apresenta $70 \%$ de seu esgoto coletado, sendo $100 \%$ deste tratado, o corpo receptor desse material é o rio Cubatão. Bertioga tem $70 \%$ de esgoto coletado, sua totalidade recebe tratamento antes de ser despejado no rio Itapanhaú. São Vicente possui $74 \%$ de seu esgoto coletado, sendo apenas $18 \%$ deste tratado. Os principais corpos receptores são: Rio Mariana, Rio Branco e Estuário de Santos. (Cetesb, 2013).

Segundo relatórios da Cetesb, na década de 80, cerca de $90 \%$ do lixo recolhido pelas prefeituras da Baixada Santista era disposto em aterros recobertos por sedimento ou em lixões a céu aberto. Atualmente, devido a Política Nacional dos Resíduos Sólidos, o lixo recolhido na Baixada Santista é encaminhado para o aterro sanitário terceirizado do Sítio das Neves. Os aterros sanitários e principalmente os lixões, somados ao material gerado pelo porto, foram considerados fontes de alto risco que contribuem para a contaminação do sistema estuarino. A parte não recolhida dos resíduos é lançada diretamente no ambiente ou incinerada (Cetesb, 2001; Cetesb 2013).

\subsection{Estudos anteriores de metais pesados na região de Santos}

Devido à grande industrialização e urbanização da região, há uma grande variedade de estudos na Baixada Santista. A contaminação do Sistema Estuarino de Santos e São Vicente por elementos e compostos químicos provenientes de fontes antrópicas vem sendo estudada desde a década de 70, com a criação da Cetesb (Companhia de Tecnologia e Saneamento Ambiental do Estado de São Paulo).

Siqueira et al. (2001) fizeram uma avaliação dos metais $\mathrm{Pb}, \mathrm{Cu}$ e $\mathrm{Cr}$ total e determinaram a especiação do Fe na forma férrica, ferrosa e total, na água de superfície, de fundo, e no sedimento, em situações de marés de quadratura e sizígia. Os teores de $\mathrm{Pb}, \mathrm{Cu}, \mathrm{Cr}$ e Fe na forma total encontraram-se acima dos valores sugeridos na literatura especializada em todos os pontos estudados.

Ferrer e Hypolito (2001) realizaram estudo abordando a geoquímica do $\mathrm{Hg}$ no estuário de Cubatão. Para esses autores, as condições de Eh e pH das águas, quando correlacionadas com o sedimento e lodo, além de indicar um ambiente favorável para a 
ocorrência de $\mathrm{Hg}$ dissolvido, também mostraram que este elemento pode precipitar pela reação com sulfeto ou se ionizar, ligando-se a partículas sólidas. Verificou-se que no sedimento, com aumento da quantidade de matéria orgânica, houve um incremento no teor de $\mathrm{Hg}$ retido, e no lodo o mercúrio variou com pequenas alterações em função dos teores de matéria orgânica.

Estudo realizado pela Cetesb (2001) analisou a contaminação da água, sedimento e organismos aquáticos no Estuário de Santos e São Vicente. Concluiu que esta pôde estar relacionada com as fontes potenciais de poluentes existentes na região. Os dados caracterizaram uma região impactada por metais pesados e outros compostos.

Siqueira e Braga (2002) estudaram a biodisponibilidade de $\mathrm{Pb}, \mathrm{Zn}$ e $\mathrm{Cu}$ nos sedimentos e avaliaram a distribuição desses metais em função da sazonalidade. Os teores dos metais associados à fração mobilizável apresentaram altas concentrações para a biota.

Abessa (2002) avaliou a qualidade dos sedimentos do Sistema Estuarino de Santos, encontrando os maiores níveis de metais no interior do estuário, próximo ao emissário submarino de Santos e no leste da Baía de Santos.

Siqueira et al. (2003) fizeram uma avaliação geoquímica ambiental, em função do aporte de matéria orgânica (carbono orgânico) e contaminantes inorgânicos (Hg e As) associados aos sedimentos de fundo dessa região. Este estudo evidenciou que há uma tendência do $\mathrm{Hg}$ e do As serem adsorvidos pela matéria orgânica, formando assim complexos organo-metálicos, segundo as correlações determinadas. Ainda para esses autores, a distribuição desses elementos químicos nos sedimentos de fundo da região parece ser influenciada pelos efluentes locais, pela circulação de água no sistema e pelos parâmetros físíco-químicos.

Siqueira et al. (2004) analisou Hg, As e matéria orgânica em sedimentos de fundo do sistema estuarino de Santos. Os resultados analíticos revelaram contaminação antrópica para alguns setores da região estuarina, estando suas fontes atribuídas ao parque industrial de Cubatão, aos efluentes da COSIPA (hoje USIMINAS) e à descarga de efluentes lançada pelo emissário submarino localizado na baía de Santos.

Aguiar (2005) avaliou o Sistema Estuarino de Santos e São Vicente quanto a características biogeoquímicas, processos de remoção e absorção de fósforo inorgânico dissolvido, teores de $\mathrm{Pb}$ dissolvido e sedimentar, transporte de propriedades e variação espacial e temporal. Para tanto, foram analisados coluna d'água e sedimentos de superfície de 
fundo. Os teores de $\mathrm{Pb}$ encontrados no sedimento estavam abaixo do limite máximo permitido pela legislação de proteção ambiental brasileira.

Hortellani et al. (2005) analisaram as concentrações de Hg em 31 amostras de sedimentos localizadas no sistema estuarino de Santos e São Vicente. Os valores obtidos de $\mathrm{Hg}$ variaram de 0,04 a 1,19 $\mathrm{\mu g} / \mathrm{g}$, sendo que cerca de 90\% das amostras apresentaram concentrações superiores ao primeiro nível sugerido pela agência ambiental canadense a partir do qual pode-se encontrar efeito adverso à biota (TEL). Entre estas, cerca de $35 \%$ possui teor de $\mathrm{Hg}>0,70 \mu \mathrm{g} / \mathrm{g}$, provável nível de ocorrência de efeito adverso à comunidade biológica (PEL), indicando um aumento devido às atividades industriais, portuárias e urbanas.

Quináglia (2006) analisou metais em sedimentos superficiais no Canal de Bertioga a fim de estabelecer níveis basais de concentrações na Baixada Santista. Fukumoto (2007) estudou histórico da contaminação do estuário santista por metais pesados e a avaliação da aplicabilidade da suscetibilidade magnética. Foram analisados os metais $\mathrm{Pb}, \mathrm{Cu}, \mathrm{Cr}$ e $\mathrm{Zn}$ em três testemunhos. Os teores de $\mathrm{Pb}, \mathrm{Cu}, \mathrm{Cr}$ e $\mathrm{Zn}$ apresentaram uma tendência de aumento em direção ao topo dos testemunhos.

Hortellani et al. (2008) aplicaram três abordagens para avaliar a contaminação por metais em 41 amostras de sedimentos do Sistema Estuarino de Santos e São Vicente: normalização com o elemento conservativo Al, análise estatística e avaliação a partir de guias de qualidade de sedimentos. Os resultados mostraram aumento nas concentrações de $\mathrm{Zn}, \mathrm{Ni}$, $\mathrm{Pb}, \mathrm{Cd}, \mathrm{Cr}$ e $\mathrm{Hg}$, que possivelmente está associado a atividades humanas. Os níveis de Al, Fe e Co provavelmente foram associados com material crustal ou processos de intemperismo natural. Cerca de $45 \%$ das amostras apresentaram concentrações superior a TEL, os níveis ocasionalmente associado a efeitos biológicos adversos. Quatro dessas amostras apresentaram concentrações acima PEL, os níveis frequentemente associadas com efeitos biológicos adversos.

Silva et al. (2008) registraram o histórico da contaminação e as fontes de 38 elementos em sedimentos do sistema estuarino de Santos-Cubatão (SE do Brasil), para tal analisou um testemunho localizado no estuário do rio Morrão. Elementos contaminantes como $\mathrm{Cr}, \mathrm{Mn}, \mathrm{Ni}, \mathrm{Zn}, \mathrm{Ga}, \mathrm{Ag}, \mathrm{Cd}, \mathrm{Sn}, \mathrm{Sb}, \mathrm{Pb}$ e $\mathrm{Bi}$ foram associados ao $\mathrm{Fe}$, derivados de atividades siderúrgicas, enquanto $\mathrm{Be}, \mathrm{Ca}, \mathrm{Sc}, \mathrm{Co}, \mathrm{Cu}, \mathrm{Sr}, \mathrm{Y}, \mathrm{Zr}, \mathrm{Nb}, \mathrm{Hf}$, Ta, Th e U estiveram associados ao $\mathrm{P}$, relacionados ao processo produtivo de fertilizantes.

Carmo et al. (2011) analisaram os metais $\mathrm{Fe}, \mathrm{Cr}, \mathrm{Ni}, \mathrm{Zn}, \mathrm{Mn}$ e $\mathrm{Cu}$ em águas, sedimentos e peixes coletados no estuário de São Vicente. As concentrações médias de $\mathrm{Cr}$, Ni 
e Zn nas águas estiveram acima dos limites estabelecidos pela legislação brasileira para águas salobras. Nos sedimentos, as maiores concentrações ultrapassaram os valores orientadores propostos pela legislação internacional: $\mathrm{Cu}, \mathrm{Ni}$ e Zn ultrapassam os limiares de efeito tóxico TEL, enquanto para o Cr, o nível de efeito provável - PEL, foi ultrapassado. Nos tecidos dos peixes, $\mathrm{Fe}, \mathrm{Cr}$ e $\mathrm{Ni}$ apresentaram maior acúmulo nas brânquias, enquanto $\mathrm{Zn}, \mathrm{Mn}$ e $\mathrm{Cu}$ ocorreram em maiores concentrações nos fígados.

Buruaem (2013) analisou a concentração de metais em sedimentos localizados em 5 diferentes regiões do Porto de Santos. Os valores obtidos indicaram contaminação para $\mathrm{Hg}$ e $\mathrm{Zn}$.

Metais desempenham um importante papel no funcionamento da vida em nosso planeta, em pequenas quantidades fazem parte da constituição dos organismos marinhos e alguns são extremamente essenciais, mas dependendo da sua concentração, são altamente tóxicos (Bryan, 1971; Templeton et al., 2000). Os estudos desses elementos são de suma importância para análise da contaminação ambiental. Dessa forma, o presente trabalho busca entender a acumulação dos metais ao longo dos anos na Baixada Santista, a fim de estimar a possível influência antrópica na região. 


\section{2. Área de Estudo}

O presente estudo foi realizado no Complexo Estuarino Santos e São Vicente (Figura 3), no litoral de São Paulo. A área de estudo está situada entre as latitudes $23^{\circ} 90^{\prime} \mathrm{S}$ e $24^{\circ}$ $00^{\prime} \mathrm{S}$ e as longitudes de $46^{\circ} 30^{\prime} \mathrm{W}$ e $46^{\circ} 50^{\prime} \mathrm{W}$. O sistema estuarino, inserido na Baixada Santista, é formado por rios, entre os quais, Cubatão, Perequê, Mogi-Piaçaguera e Itapanhaú.

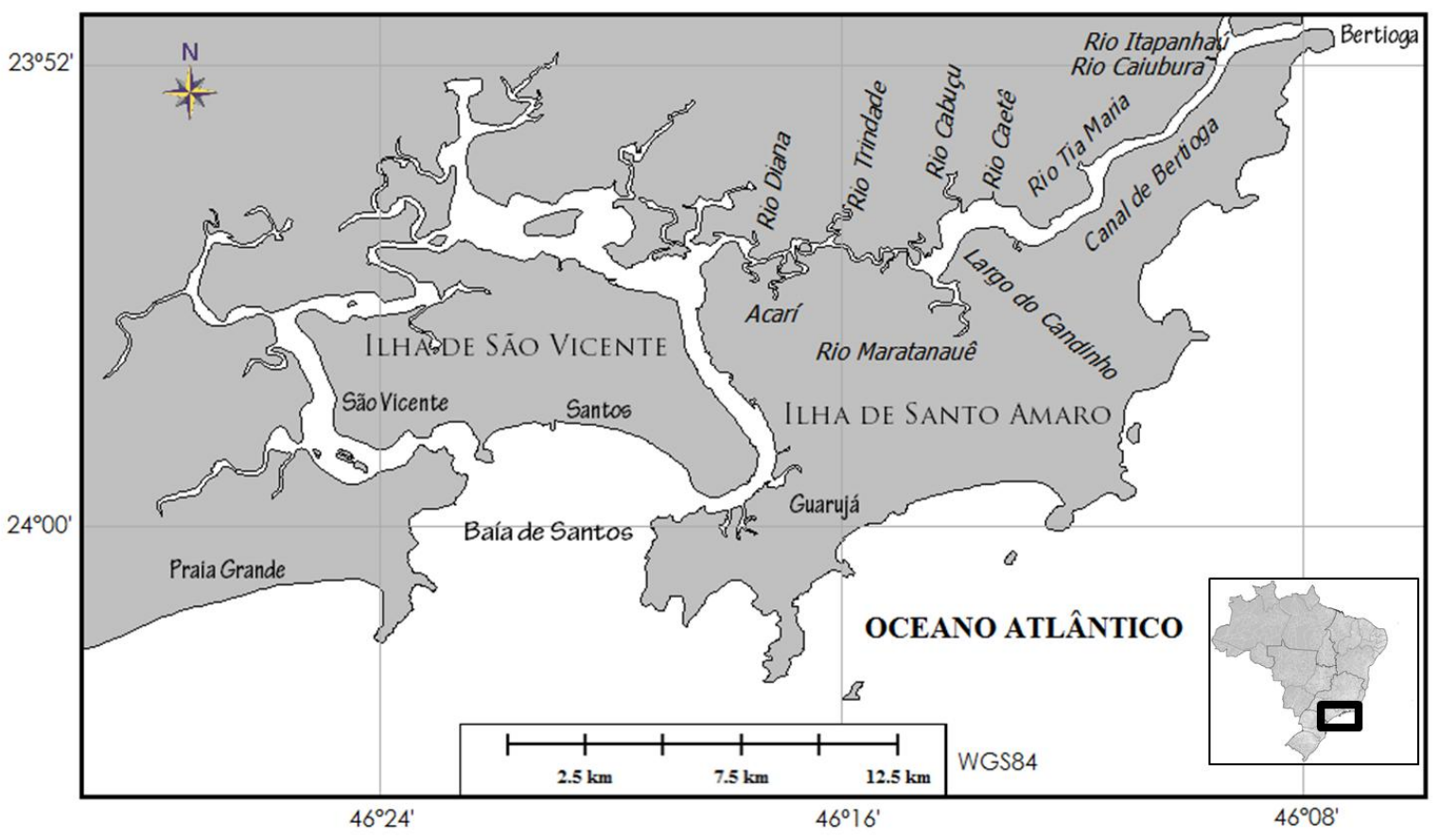

Figura 3. Sistema Estuarino Santos-São Vicente.

Suguio e Martin (1978) dividiram o litoral paulista em quatro grandes unidades (Cananéia-Iguape, Itanhaém-Santos, Bertioga, Ilha de São Sebastião e Ilha de São SebastiãoSerra de Paratí), cujos limites naturais são dados pela presença de pontões do embasamento pré-cambriano. A Baixada Santista está localizada no domínio da Província Costeira (IPT, 1981), inserida no compartimento geológico litorâneo, limitada a oeste pela falha de Cubatão, e a leste pela falha de Santos, compondo-se de rochas do Complexo Costeiro e da Suite Granítica Indiferenciada. O domínio da Província Costeira subdivide-se nas subzonas Serra do Mar e Baixada Litorânea (Almeida e Carneiro, 1998).

A subzona Serra do Mar apresenta relevo abrupto formado predominantemente por escarpas fastonadas, com desníveis totais da ordem de 800 a 1200 metros entre as bordas do Planalto Atlântico e as baixadas litorâneas. A subzona das baixadas litorâneas apresenta 
relevo de terrenos baixos, predominantemente planos, com baixa densidade de drenagem, de padrão meandrante, e com altitudes pouco elevadas em relação ao nível do mar atual. (IPT, 1981).

A planície costeira de Santos tem a forma de um crescente de $40 \mathrm{~km}$ de extensão por $15 \mathrm{~km}$ de largura máxima, sendo delimitada nas suas extremidades, pela serra de Mongaguá, ao sul, e pela parte rochosa da ilha de Santo Amaro ao norte. Na parte central e nordeste a planície é drenada por uma rede de lagunas e canais de maré que delimitam as ilhas de São Vicente e Santo Amaro.

\subsection{Hidrodinâmica e sedimentação no Estuário de Santos e São Vicente}

Em relação à circulação, o Sistema Estuarino de Santos e São Vicente é constituído por quatro compartimentos determinados em função do padrão de circulação existente: Baía de Santos, Canal de Santos, Canal de São Vicente e Canal de Bertioga. A onda de maré é semidiurna e se propaga simultaneamente pelos canais de Santos e São Vicente e pelo Canal de Bertioga. As amplitudes médias variam de $27 \mathrm{~cm}$ na quadratura a $123 \mathrm{~cm}$ na sizígia (Harari et al., 1990).

O processo básico que ocorre na circulação estuarina é a mistura de água doce oriunda da drenagem continental com a água salgada do oceano. Os fatores essenciais que controlam esse processo são as marés e as correntes fluviais residuais, com efeito de ondas e diferenças de salinidade e, consequentemente, densidade causadas pela mistura entre águas fluviais e as advindas do oceano adjacente.

O estuário Santista não se enquadra num modelo simples de circulação estuarina, possuindo transições entre diversos tipos; no Canal do Porto tem-se uma circulação do tipo cunha salina com transição para uma circulação de estuário, não restrito, de contato misto (Fulfaro e Ponçano, 1976). Na circulação de um estuário misto, a forçante predominante consiste na variação periódica do nível do mar, sendo que o fluxo de água doce pode ocorrer na camada superior ou inferior, além de se misturar com a água salgada (Fulfaro e Ponçano, 1976).

Na região do Alto Estuário, as águas dos rios provenientes da Serra do Mar adentram o sistema, originando um predomínio de fluxo unidirecional que se propagam em direção à baía (Harari et al., 1990). Este padrão é corroborado por Fulfaro e Ponçano (1976), que indicam que essa característica é notada principalmente no Canal do Porto. Na parte centro- 
oriental da baía, o fluxo resultante unidirecional segue em direção à Ponta da Munduba, saído para o mar aberto entre as Ilhas da Moela e de Santo Amaro

Nos canais estreitos do Estuário Santista, a maré vazante implica a predominância de água doce, enquanto a maré enchente atua em favorecer a manutenção de águas salobras nesta região, definindo uma circulação estuarina homogênea. Nos largos (Pombeba e São Vicente) ocorrem efeitos mínimos dos fluxos fluviais residuais, havendo circulação predominantemente por correntes de marés, constituindo-se em zonas de baixa energia. $\mathrm{O}$ mesmo ocorre no Canal de Bertioga, que mostra áreas de influência de correntes de maré junto à cidade de Bertioga, mas de pouca penetração em direção à desembocadura do Rio Sandi, local em que ocorre barras mais arenosas que dificultam o transporte de fundo no sentido Bertioga-Canal do Porto.

A Figura 4 (modificada de Kutner, 1976) mostra um esquema geral de circulação no interior do Canal de Santos. Tommasi (1979) discutiu com base nesta circulação a existência de uma área de assoreamento em frente ao cais do Valongo e de Paquetá e, entre o primeiro e a Ilha de Barnabé. Isso leva a tendência de formação de um giro de água no largo, em rente ao Canal de Bertioga, Ilha de Barnabé, Ilha de São Vicente e Ilha de Santo Amaro.

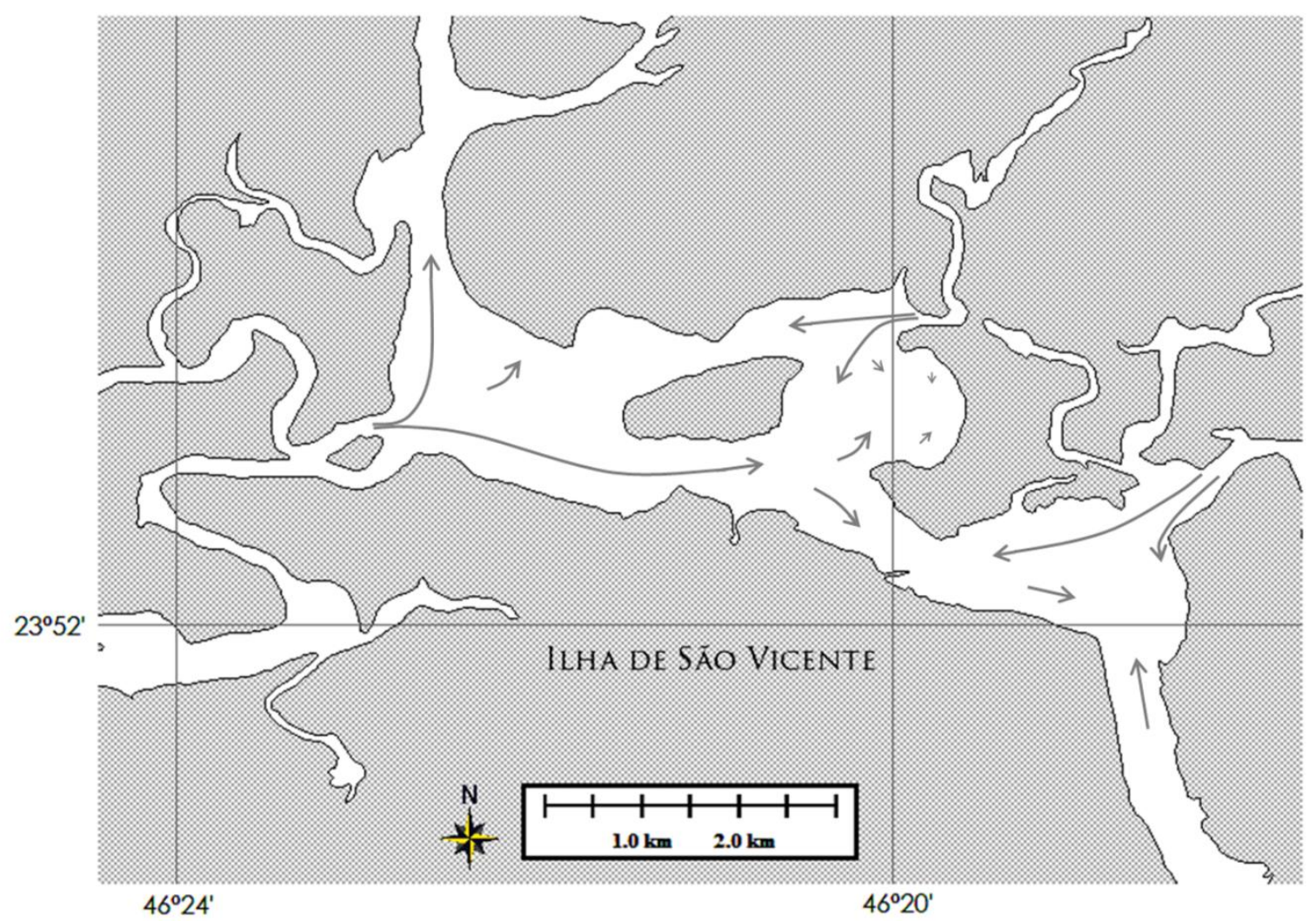

Figura 4. Esquema geral da circulação no interior do Canal de Santos. (modificada de Kutner, 1976). 
O Estuário de Santos apresenta a predominância de depósitos de silte fino, passando pelas gradações de silte até areia muito fina, configurando-o como ambiente de sedimentação caracterizado por baixa energia e baixa taxa de floculação. Segundo Fulfaro e Ponçano (1976), o Sistema Estuarino de Santos e São Vicente apresenta como característica uma taxa de sedimentação equilibrada. Taxas elevadas ocorrem apenas localmente, destacando-se as extremidades sul dos canais de São Vicente e do Porto, junto à desembocadura da baía, o Canal de Bertioga e o Largo do Canéu.

\subsection{Hidrodinâmica e sedimentação do Canal de Bertioga}

No Canal se encontra a foz do rio Itapanhaú, que constitui a principal bacia hidrográfica da área e a principal fonte potencial de sedimentos, cuja descarga ocorre a apenas 2,5 km da desembocadura do Canal. Possui $25 \mathrm{~km}$ de extensão e largura média de $460 \mathrm{~m}$, com profundidade que variam entre 3 a 15 metros (Schaeffer-Novelli, 1986).

A composição sedimentar do Canal é de sedimentos finos, principalmente lama com altos teores de carbono, nitrogênio e enxofre nas regiões mais internas. Já as regiões mais externas (desembocaduras do canal) apresentam sedimentos arenosos com baixos teores de material orgânico (Eichler, 2001).

Entre as áreas do continente e a Ilha de Santo Amaro, ocorre uma mistura de águas continentais de desembocaduras de rios e águas marinhas, favorecendo a formação de condições estuarinas. Por ser uma região de baixa energia e zona de mistura entre água salgada e água doce com temperaturas relativamente altas, propicia também o desenvolvimento do manguezal (Tognella, 1995). Além da presença do manguezal, são encontrados também ambientes como restinga, mata atlântica, praias, rios e zona estuarina (Soares, 1997).

De acordo com o DHN (1997), o Canal de Bertioga possui regime de micromarés e o sistema de meandramento de canais possui grande influência na circulação estuarina e no comportamento das marés. As marés mistas são predominantemente semidiurnas com desigualdades diurnas, de amplitude moderada em torno de 0,73m (Miranda e Castro, 1991).

As áreas de maior influência das correntes de maré podem ser observadas junto à cidade de Bertioga, na desembocadura do Canal, com um pequeno decréscimo desta 
influência na região nas proximidades da confluência do Canal de Bertioga com o Canal do Porto, em Santos (Miranda e Castro, 1991).

Os rios que desembocam no Canal da Bertioga parecem ter a sua carga sedimentar depositada pela ação das correntes de maré devido à propagação em sentido oposto da desembocadura. Este fato resulta em uma movimentação das correntes de fundo em velocidades inferiores à velocidade crítica de transporte, eliminando o transporte de fundo. Isto caracteriza o Canal da Bertioga como um corredor onde predomina o transporte de sedimentos finos em suspensão. Estes sedimentos são depositados, preferencialmente, junto à área de confluência de correntes de maré junto ao largo do Candinho. Esta região corresponde a uma das raras áreas do estuário santista em que se depositam predominantemente sedimentos argilosos, com alta porcentagem de matéria orgânica (Miranda e Castro, 1991). 


\section{Objetivos}

O presente trabalho tem como principal objetivo a reconstrução ambiental do Estuário de Santos e São Vicente no âmbito da poluição da região. Para isso, foram analisados nove testemunhos, que permitiram uma visão histórica do reflexo da antropização nesse ambiente costeiro.

A partir desse objetivo principal foram estabelecidas as seguintes etapas de trabalho:

- Determinar os níveis de $\mathrm{Al}, \mathrm{As}, \mathrm{Cr}, \mathrm{Cu}, \mathrm{Fe}, \mathrm{Hg}, \mathrm{Mn}, \mathrm{Ni}, \mathrm{Pb}, \mathrm{Sc}, \mathrm{V}$, e $\mathrm{Zn}$ em amostras de nove testemunhos localizados no Canal da Bertioga - SP e Alto Estuário Santista;

- Determinação dos valores naturais ou basais da região (background);

- Estimar parâmetros importantes na avaliação de metais em sedimentos tais como: fator de enriquecimento e parâmetros de poluição. 


\section{Material e Métodos}

\subsection{Amostragem}

Em fevereiro de 2010 foram realizadas cinco coletas de testemunhos longos (entre 150 e $220 \mathrm{~cm}$ ) ao longo do Canal de Bertioga, como parte do projeto Fapesp (2009/01211-0) "Histórico da atividade antrópica no Canal de Bertioga, SP. Níveis de metais, semimetais e sedimentação recente em coluna sedimentares". Em abril de 2012 foram coletados quatro testemunhos longos distribuídos ao longo do estuário santista, como parte do projeto Fapesp (2011/50581-4) "Susceptibilidade e resiliência de sistemas estuarinos urbanos a mudanças globais: balanço hidro-sedimentar; elevação do nível do mar; resposta a eventos extremos)". A localização dos nove testemunhos pode ser observada na Figura 5. A Tabela 1 apresenta as coordenadas e o comprimento aproximado dos testemunhos amostrados.

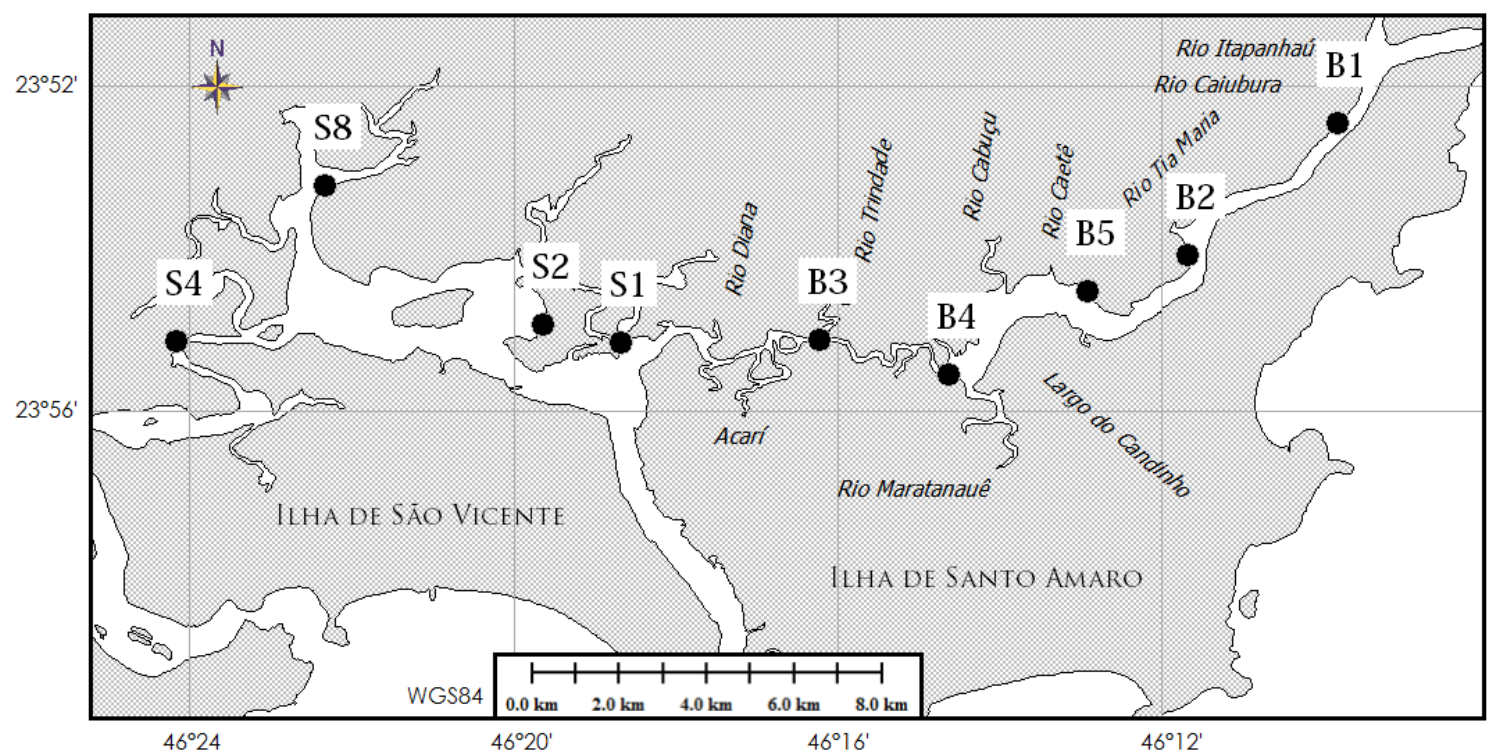

Figura 5. Localização dos testemunhos coletados ao longo do Estuário Santos e São Vicente.

Em laboratório, os testemunhos foram descritos segundo alguns critérios, como coloração, presença de conchas, presença de bioturbações, estimativa da granulometria entre outros. Em seguida, fez-se a amostragem da coluna sedimentar a cada $2 \mathrm{~cm}$. 
Tabela 1. Coordenadas e comprimento aproximado dos testemunhos coletados no Canal de Bertioga.

\begin{tabular}{|c|c|c|c|}
\hline Testemunho & Latitude & Longitude & Comprimento (cm) \\
\hline Santos 1 (S1) & $23^{\circ} 55,152^{\prime}$ & $46^{\circ} 18,658^{\prime}$ & 148 \\
\hline Santos 2 (S2) & $23^{\circ} 54,859^{\prime}$ & $46^{\circ} 19,874^{\prime}$ & 172 \\
\hline Santos 4 (S4) & $23^{\circ} 55,088^{\prime}$ & $46^{\circ} 24,344^{\prime}$ & 192 \\
Santos 8 (S8) & $23^{\circ} 53,176^{\prime}$ & $46^{\circ} 22,219^{\prime}$ & 176 \\
\hline Bertioga 1 (B1) & $23^{\circ} 52,428^{\prime}$ & $46^{\circ} 09,724^{\prime}$ & 204 \\
\hline Bertioga 2 (B2) & $23^{\circ} 54,079^{\prime}$ & $46^{\circ} 11,656^{\prime}$ & 202 \\
\hline Bertioga 3 (B3) & $23^{\circ} 55,127^{\prime}$ & $46^{\circ} 16,233^{\prime}$ & 150 \\
Bertioga 4 (B4) & $23^{\circ} 55,553^{\prime}$ & $46^{\circ} 14,578$ & 156 \\
Bertioga 5 (B5) & $23^{\circ} 54,537^{\prime}$ & $46^{\circ} 12,920^{\prime}$ & 188 \\
\hline
\end{tabular}

Como parte da preparação das amostras, elas foram submetidas a uma liofilização. Esse processo permite que seja retirada toda a água presente na amostra sem que os grãos de sedimento sejam danificados.

\subsection{Datação dos testemunhos e cálculo da Taxa de Sedimentação}

Para a espectrometria gama, os testemunhos abertos foram caracterizados e fatiados a cada 1 ou $2 \mathrm{~cm}$. As amostras fatiadas foram inicialmente liofilizadas e, em seguida, moídas e colocadas em potes plásticos adequados à espectrometria gama, aproximadamente entre $15 \mathrm{e}$ $25 \mathrm{~g}$ de amostra foram necessários para a análise. A metodologia de determinação do radionuclídeo ${ }^{210} \mathrm{~Pb}$ foi estabelecidas em nosso laboratório e estão descritas detalhadamente em Figueira et al. (1998) e Saito et al. (2001).

Os valores de datação e taxa de sedimentação foram calculados a partir do princípio da determinação de ${ }^{210} \mathrm{~Pb}$ estabelecidos por Appleby e Oldfield (1978) a partir da medida da emissão de seus raios gama. Os resultados foram obtidos a partir do trabalho de Ferreira (2014), também parte dos projetos citados anteriormente.

\subsection{Análise granulométrica de sedimentos finos}


O termo granulometria significa medida de tamanho dos grãos, sendo uma de suas características físicas fundamentais. A análise, que permite estabelecer uma expressão quantitativa da distribuição granulométrica é conhecida como análise ganulométrica (Suguio, 1973). Ela possibilita a quantificação dos componentes, areia, silte e argila, expressos em percentagem de cada fração granulométrica.

Optou-se por determinar nas amostras de sedimento deste estudo apenas a porcentagem da fração fina (silte + argila) que é fração menor do que 0,062 mm, isso devido a maior parte dos contaminantes serem adsorvidas nos grãos finos, onde a superfície de contato é maior (Förstner e Salomons, 1980). Variações nas concentrações dos elementos em função da granulometria do sedimento são atribuídas a diferenças no seu potencial de adsorção sobre minerais argilosos, óxidos metálicos e matéria orgânica, os quais tendem a estar concentrados em agregados menores (Kersten e Förstner, 1995).

A determinação de silte e argila foi feita por peneiramento úmido passando-se uma alíquota da amostra ( $10 \mathrm{~g}$ de sedimento seco) pela peneira de $0,062 \mathrm{~mm}$. O material que ficou retido na peneira foi seco em estufa a $60{ }^{\circ} \mathrm{C}$ e pesado novamente para determinação do teor de areia $(>0,062 \mathrm{~mm})$. A diferença da massa inicial menos a massa de areia é a fração fina $(<0,062 \mathrm{~mm})$ que corresponde às frações silte mais argila, aquelas as quais são importantes para o estudo dos metais.

\subsection{Análise da Variação da Suscetibilidade Magnética}

A suscetibilidade magnética pode ser utilizada como método alternativo rápido e efetivo para estimar a situação ecológica e para mapear as principais fontes de poluição por metais. Pode-se utilizar essa metodologia para complementar as investigações geoquímicas, que acabam por consumir um grande tempo (Oldfield, 1991; Verosub e Roberts, 1995; Dekkers, 1997).

Muitas emissões antrópicas contêm finas partículas altamente magnéticas. Assim, a suscetibilidade magnética pode fornecer uma visão geral do grau de poluição. Alguns estudos demonstraram a aplicabilidade das medidas de suscetibilidade magnética para estimar o grau de poluição dos solos por metais pesados em áreas industriais de diferentes regiões como Nulman e Meshcheryakov (1994), Georgeaud et al. (1994) e Hanesch e Scholger (2002). 


\subsubsection{Princípios do método}

A suscetibilidade magnética volumétrica $\kappa$, adotada no resente estudo, é adimensional, e expressa em "SI". Seu cálculo dá-se segundo a equação:

$$
\kappa=\frac{\mathrm{J}}{\mathrm{H}}
$$

onde:

- $\quad \kappa$ é a suscetibilidade magnética volumétrica;

- $\quad J$ é o momento magnético dipolar por volume unitário;

- $\quad H$ é a intensidade do campo magnético aplicado.

A suscetibilidade magnética de massa $\chi$ é expressa e $\mathrm{m}^{3} \cdot \mathrm{kg}^{-1}$, e pode ser calculada segundo a equação (Correia, 1994):

$$
\chi=\frac{\kappa}{\rho}
$$

onde:

- $\quad \chi$ é a suscetibilidade magnética de massa;

- $\quad \kappa$ é a suscetibilidade magnética volumétrica;

- $\quad \rho$ é a densidade do material.

Após a coleta, os testemunhos foram analisados quanto à variação da suscetibilidade magnética, utilizando-se um perfilador Bartington MS2C, numa frequência de 0,565 kHz. O tempo de leitura para cada subamostra de $2 \mathrm{~cm}$ foi de 10 segundos.

\subsection{Análises Químicas}

\subsubsection{Digestão parcial de sedimento para a análise de metais e semimetais}

Para analisar a disponibilidade no ambiente, a abertura das amostras foi realizada mediante lixiviação por ataque ácido, segundo método SW 846 US EPA 3050B (USEPA, 1996). Este método consiste em uma digestão ácida capaz de dissolver a maior parte dos 
elementos de origem antrópica. Os elementos ligados a estruturas silicáticas não são dissolvidos por este procedimento. O equipamento utilizado foi um ICP-OES, marca Varian, modelo 710-ES (Vista MPX).

Para isso, $2 \mathrm{~g}$ de sedimento seco foi digerido com $10 \mathrm{~mL}$ de $\mathrm{HNO}_{3}$ (1:1) sob aquecimento a $95^{\circ} \mathrm{C}$ por 15 minutos. Adicionou-se $5 \mathrm{~mL}$ de $\mathrm{HNO}_{3}$ concentrado e o aquecimento continuou por mais 30 minutos. Adicionou-se $5 \mathrm{~mL}$ de $\mathrm{HNO}_{3}$ concentrado até a completa oxidação da amostra, verificada pela ausência de vapores marrons, continuando o aquecimento por mais 1 hora e 30 minutos. A solução foi resfriada, adicionou-se então $2 \mathrm{~mL}$ de água e $3 \mathrm{~mL}$ de $\mathrm{H}_{2} \mathrm{O}_{2} 30 \%$, sob aquecimento. O procedimento continuou com a adição de 1 $\mathrm{mL}$ de $\mathrm{H}_{2} \mathrm{O}_{2} 30 \%$, até a completa eliminação da matéria orgânica. Adicionou-se, enfim, $10 \mathrm{ml}$ de $\mathrm{HCl}$ concentrado. A solução foi filtrada em papel de filtro faixa lenta e, a seguir, foi diluída para 100 mL em balão volumétrico, procedendo-se então a análise por ICP-OES.

Analisaram-se os metais e semimetais: alumínio (Al), arsênio (As), cromo (Cr), cobre $(\mathrm{Cu})$, ferro $(\mathrm{Fe})$, manganês $(\mathrm{Mn})$, níquel $(\mathrm{Ni})$, chumbo $(\mathrm{Pb})$, escândio $(\mathrm{Sc})$, vanádio $(\mathrm{V})$ e zinco $(\mathrm{Zn})$.

\subsubsection{Determinação de mercúrio $(\mathrm{Hg})$ por geração de vapor}

O princípio da geração de vapor possibilita a determinação de elementos metálicos, em amostras marinhas e geológicas, destacando-se o $\mathrm{Hg}$, além de outros elementos importantes do ponto de vista de impacto ambiental.

O processo de digestão do Hg foi baseado no método descrito em SW 846 US EPA 7471 A (USEPA, 1994). Nessa metodologia, pesou-se aproximadamente 0,6g de amostra seca. Foram adicionados $1,7 \mathrm{ml}$ de água mili-Q e 1,7 $\mathrm{ml}$ de água régia ( $\mathrm{HNO} 3: \mathrm{HCl})$. A solução foi aquecida por 2 minutos a $95^{\circ} \mathrm{C}$. Resfriou-se a amostra, em seguida foram adicionados 16,4 $\mathrm{ml}$ de água mili-Q e 4,9 $\mathrm{ml}$ de permanganato de potássio (KMnO4 5\%). A solução foi, em seguida, aquecida por 30 minutos a $95^{\circ} \mathrm{C}$. Esfriou-se a amostra e em seguida adicionou-se 2,0 $\mathrm{ml}$ de cloridrato de hidroxilamina $(\mathrm{NH} 2 \mathrm{OHCl} 12 \%)$ a fim de reduzir o excesso de permanganato de potássio. A solução foi filtrada em papel de filtro faixa lenta e, a seguir, foi diluída para $40 \mathrm{~mL}$ em balão volumétrico. A leitura foi efetuada por meio da técnica de geração de vapor acoplado a espectrometria de emissão ótica com plasma indutivamente acoplado (VGA-ICP-OES). 


\subsubsection{Digestão total dos sedimentos da base dos testemunhos}

Os sedimentos da base do testemunho foram digeridos totalmente para se estabelecer um "background" regional para região. Para a digestão completa das amostras de sedimento utilizou-se, com algumas modificações, o procedimento EPA 3052 (USEPA, 1996), recomendado pela Agência de Proteção Ambiental dos Estados Unidos. Este procedimento é adotado quando se deseja fazer uma digestão total da amostra de sedimento, em forno de microondas, para a determinação de metais.

Pesou-se cerca de 0,25 g de amostra em tubo de digestão de Teflon, ao qual foram adicionados $10 \mathrm{~mL}$ de $\mathrm{HNO}_{3}$ concentrado. A mistura foi levada ao forno de microondas (sistema fechado) e a digestão foi feita usando-se um programa recomendado pelo fabricante do equipamento, com 40 minutos de duração. Ao término do programa, os tubos de digestão foram abertos e adicionaram-se cerca de 2 a $5 \mathrm{~mL}$ de $\mathrm{HF} 40 \%$, para o ataque dos silicatos. Repetiu-se o programa de digestão fechada. Novamente, ao término da etapa, adicionou-se ao tubo de digestão $1 \mathrm{~mL}$ de $\mathrm{H}_{2} \mathrm{O}_{2} 30 \%$, para o ataque da matéria orgânica, e repetiu-se mais uma vez o programa de dissolução ácida fechada. A solução obtida foi, então, filtrada em papel de filtro Whatman $n^{\circ} 40$, para a retenção de eventuais partículas que estivessem em suspensão. $O$ filtrado foi transferido para um béquer de teflon, que foi levado a uma chapa de aquecimento. A solução foi evaporada à secura e retomada com $20 \mathrm{~mL}$ de solução diluída de $\mathrm{HNO}_{3}$ a $5 \%$ (v/v), por três vezes. O resíduo remanescente foi transferido para um balão de $50 \mathrm{~mL}$ com água destilada. A determinação das concentrações totais dos elementos foi feita por meio da técnica de ICP OES.

\subsubsection{Carbono Orgânico Total}

Para a análise do teor de carbono orgânico total pesou-se 1,0g de amostra. Esta foi atacada inicialmente com 2,0 mL de $\mathrm{HCl} 1 \mathrm{~mol} / \mathrm{L}$. Após 1 dia, adicionou-se algumas gotas de $\mathrm{HCl}$ concentrado afim de verificar se ainda há ocorrência de reação. Quando sim, a amostra foi novamente tratada com ácido, até que todo o carbonato fosse consumido. Finalizada a queima, a amostra passou por um processo de lavagem, até que seu $\mathrm{pH}$ se tornasse neutro.

Aproximadamente $10 \mathrm{mg}$ de sedimento foram acondicionados em cartuchos de estanho (5 x $9 \mathrm{~mm})$ e submetidos a análise elementar e isotópica no analisador elementar Costec Instruments Elemental Combustion System acoplado ao detector de espectrometria de massas com razão isotópica Thermo Scientific Delta V Advantage Isotope Ratio MS (EA- 
IRMS). A calibração para a análise isotópica de carbono foi feita através do gás de referência $\left(\mathrm{CO}_{2}-{ }^{13} \mathrm{C}-32,892 \%\right)$.

\subsubsection{Limites de detecção do equipamento (LDE)}

O limite de detecção do equipamento (LD) é a menor concentração que um analito pode ser detectado, mensurado e reportado com $99 \%$ de confiança de que a sua concentração é maior do que zero (Wade e Cantillo, 1994).

Para a determinação do limite de detecção do método (LDM) dos elementos em estudo, foi realizada a análise de sete replicatas com concentrações conhecidas, preparadas a partir de soluções padrão. A concentração conhecida era a menor que o equipamento conseguiu detectar para cada elemento, o desvio-padrão das sete medidas foi multiplicado pelo valor de t-Student $(3,143)$ para um nível de confiança de $99 \%$.

O limite de quantificação do método (LQM) foi determinado considerando cinco vezes o LDM, o fator de diluição e a massa de sedimento utilizada no método de extração.

As linhas de emissão utilizadas na determinação de cada elemento, bem como os limites de detecção do método (LDM) e o limite de quantificação do método (LQM) estão apresentados na Tabela 2.

Tabela 2. Valores de limite de detecção para os metais analisados.

\begin{tabular}{|c|c|c|c|}
\hline Elemento & $\begin{array}{c}\text { Comprimento de } \\
\text { onda (nm) }\end{array}$ & $\begin{array}{c}\text { Limite de detecção } \\
\text { do método } \\
(\mathbf{m g} / \mathbf{k g})\end{array}$ & $\begin{array}{c}\text { Limite de } \\
\text { quantificação do } \\
\text { método } \\
\text { (mg/kg) }\end{array}$ \\
\hline $\mathbf{A l}$ & 396,152 & 0,3 & 1,6 \\
$\mathbf{A s}$ & 188,980 & 0,1 & 0,4 \\
$\mathbf{C r}$ & 267,716 & 0,1 & 0,5 \\
$\mathbf{C u}$ & 327,395 & 0,07 & 0,3 \\
$\mathbf{F e}$ & 238,204 & 0,2 & 1,2 \\
$\mathbf{H g}$ & 194,164 & 0,0059 & 0,0177 \\
$\mathbf{M n}$ & 257,610 & 0,2 & 1,0 \\
$\mathbf{N i}$ & 231,604 & 0,05 & 0,3 \\
$\mathbf{P b}$ & 220,353 & 0,1 & 0,7 \\
$\mathbf{V}$ & 292,401 & 0,2 & 1,0 \\
\hline $\mathbf{Z n}$ & 213,857 & 0,4 & 2,0 \\
\hline
\end{tabular}




\subsubsection{Controles da qualidade analítica}

A fim de manter a qualidade dos resultados analíticos, alguns controles foram realizados. A cada dez amostras analisadas, uma amostra padrão, com concentração conhecida, foi medida novamente para realizar a variação do equipamento. Para certificar que não houve efeito de memória no ICP-OES, um branco foi analisado após a leitura das amostras.

Dois materiais de referência certificados de solos contaminados SS-1 e SS-2 (EnviroMAT Contaminated Soil) foram submetidos ao mesmo método de extração das amostras EPA 3050B para controle da qualidade analítica, verificando a eficiência de extração.

Foram realizados brancos de reagentes também sujeitos a mesma extração, a fim de eliminar as possibilidades de contaminações através dos mesmos.

Para verificação da eficiência de extração dos elementos do método EPA 3050B foram utilizados os materiais de referência certificados de solos contaminados. Na Tabela 3 e Tabela 4 estão apresentados os resultados obtidos das médias dos materiais de referência utilizados: SS-1 e SS-2 (n=9), bem como o valor certificado, o intervalo de tolerância e as porcentagens de recuperação.

Tabela 3. Resultados do material de referência certificado SS-1.

\begin{tabular}{|c|c|c|c|c|c|}
\hline Elemento & $\begin{array}{c}\text { Valor de } \\
\text { Referência } \\
(\mathbf{m g} / \mathbf{k g})\end{array}$ & $\begin{array}{c}\text { Intervalo de } \\
\text { Confiança } \\
(\mathbf{m g} / \mathbf{k g})\end{array}$ & $\begin{array}{c}\text { Intervalo de } \\
\text { Tolerância } \\
(\mathbf{m g} / \mathbf{k g})\end{array}$ & $\begin{array}{c}\text { Média SS-1 } \\
(\mathbf{n = 9 )} \\
(\mathbf{m g} / \mathbf{k g})\end{array}$ & $\begin{array}{c}\text { Taxa de } \\
\text { recuperação } \\
(\mathbf{\%})\end{array}$ \\
\hline $\mathbf{A l}$ & 9518 & $8417-10619$ & $3276-15760$ & 9795,22 & 102,91 \\
$\mathbf{A s}$ & 18 & $17-19$ & $13-23$ & 17,16 & 95,33 \\
$\mathbf{C d}$ & 34 & $32-36$ & $24-44$ & 27,05 & 79,56 \\
$\mathbf{C r}$ & 64 & $55-73$ & $13-115$ & 48,98 & 76,53 \\
$\mathbf{C u}$ & 690 & $657-723$ & $503-877$ & 558,87 & 81,00 \\
$\mathbf{F e}$ & 20406 & $19037-21775$ & $12645-28167$ & 22578,04 & 110,64 \\
$\mathbf{M n}$ & 425 & $406-444$ & $317-533$ & 461,98 & 108,70 \\
$\mathbf{N i}$ & 231 & $218-244$ & $157-305$ & 196,40 & 85,02 \\
$\mathbf{P b}$ & 233 & $219-247$ & $152-314$ & 177,01 & 75,97 \\
$\mathbf{V}$ & 19 & $17-21$ & $8-30$ & 18,35 & 96,60 \\
$\mathbf{Z n}$ & 6775 & $6467-7083$ & $5066-8484$ & 6723,44 & 99,24 \\
\hline
\end{tabular}


Tabela 4. Resultados do material de referência certificado SS-2.

\begin{tabular}{|c|c|c|c|c|c|}
\hline Elemento & $\begin{array}{c}\text { Valor de } \\
\text { Referência } \\
(\mathbf{m g} / \mathbf{k g})\end{array}$ & $\begin{array}{c}\text { Intervalo de } \\
\text { Confiança } \\
(\mathbf{m g} / \mathbf{k g})\end{array}$ & $\begin{array}{c}\text { Intervalo de } \\
\text { Tolerância } \\
(\mathbf{m g} / \mathbf{k g})\end{array}$ & $\begin{array}{c}\text { Média SS-2 } \\
(\mathbf{n = 9}) \\
(\mathbf{m g} / \mathbf{k g})\end{array}$ & $\begin{array}{c}\text { Taxa de } \\
\text { recuperação } \\
(\mathbf{\%})\end{array}$ \\
\hline $\mathbf{A l}$ & 13265 & $12114-14416$ & $6743-19787$ & 13297,93 & 100,25 \\
$\mathbf{A s}$ & 75 & $65-85$ & $25-125$ & 76,40 & 101,87 \\
$\mathbf{C d}$ & 2 & - & - & 2,06 & 102,83 \\
$\mathbf{C r}$ & 34 & $30-38$ & $14-54$ & 29,58 & 87,00 \\
$\mathbf{C u}$ & 191 & $182-200$ & $139-243$ & 172,38 & 90,25 \\
$\mathbf{F e}$ & 21046 & $19597-22495$ & $12831-29261$ & 19581,29 & 93,04 \\
$\mathbf{M n}$ & 457 & $433-481$ & $324-590$ & 503,14 & 110,10 \\
$\mathbf{N i}$ & 54 & $50-58$ & $33-75$ & 45,69 & 84,62 \\
$\mathbf{P b}$ & 126 & $116-136$ & $68-184$ & 94,58 & 75,07 \\
$\mathbf{V}$ & 34 & $31-37$ & $17-51$ & 35,45 & 104,25 \\
$\mathbf{Z n}$ & 467 & $444-490$ & $337-597$ & 421,26 & 90,20 \\
\hline
\end{tabular}

Os resultados dos valores de recuperação obtidos para os materiais de referência analisados confirmaram a eficácia do método para todos os elementos em estudo, com porcentagem de recuperação dentro da faixa recomendada pela USEPA (1996) entre 75 e 125 $\%$.

A fim de eliminar as possíveis fontes de contaminação da amostra, foi realizado um branco de reagentes. Nele os reagentes utilizados nas análises foram submetidos ao mesmo método de extração. O resultado do branco analítico demonstrou que não houve contaminações por conta dos reagentes utilizados durante as solubilizações.

\subsection{Avaliação dos níveis de metais por índices e parâmetros de poluição}

Vários fatores podem alterar a acumulação de metais no sedimento, os métodos de normalização buscam, de certa forma, minimizar esse erro. Alguns métodos de normalização têm sido muito utilizados a fim de detectar as concentrações dos elementos no sedimento. Segundo Clark et al. (2000) os procedimentos podem ser divididos em cinco grupos principais: normalização por tamanho das partículas (grunulometria); extrapolação da curva de regressão; correção com mineral inerte; fração quimicamente móvel e comparação com elemento conservativo (fator de enriquecimento). Todos os métodos apresentam vantagens e desvantagens. Segundo Hortellani et al. (2008), a melhor forma de minimizar esses erros é a 
combinação de métodos diferentes. Optou-se no presente trabalho pela utilização do Fator de Enriquecimento e dos parâmetros de poluição: Pollution Load Index (PLI) e Ecological Risk Index (RI).

\subsubsection{Fator de Enriquecimento (FE)}

O fator de enriquecimento (Szefer et al., 1998) é muito utilizado no tratamento de dados de metais. Ele propicia a análise da contribuição de alguns metais para a coluna sedimentar e função do tempo. Para tal, utiliza-se um elemento normalizador, o que permite uma uniformização dos dados. O cálculo do fator de enriquecimento é feito baseado na seguinte equação:

$$
F E=\frac{\left(\frac{M}{X}\right)_{\text {amostra }}}{\left(\frac{M}{X}\right)_{\text {referência }}}
$$

onde $\mathrm{M}$ é o metal analisado e X é o elemento normalizador.

Nesse caso, foi utilizado como elemento normalizador o Sc. Como valor de referência optou-se por utilizar aqueles obtidos nas amostras de base do testemunho a partir da digestão total. Valores de FE abaixo de 2 são considerados normais, ou seja, provenientes principalmente de fontes geogênicas (composição geológica). Valores entre 2 e 5 representam uma contaminação moderada. Os valores entre 5 e 20 são característicos de uma poluição considerada significativa. Valores encontrados entre 20 e 40 caracterizam uma poluição alta. Por fim, valores encontrados acima de 40 indicam um local extremamente poluído (Andrews e Sutherland, 2004).

\subsubsection{Parâmetros de Poluição}

\section{Pollution Load Index (PLI)}

A fim de melhor compreender o comportamento dos metais ao longo dos testemunhos foram utilizados outros dois índices, o primeiro é o Pollution Load Index (PLI), 
desenvolvido por Tomlinson et al. (1980) e utilizado para calcular o grau de poluição em diferentes sistemas estuarinos (Caeiro et al., 2005; Harikumar et al., 2009). O PLI foi calculado pela seguinte expressão:

$$
\mathrm{PLI}=\sqrt[n]{F C_{1} \times F C_{2} \times F C_{3} \times \ldots \times F C_{n}}
$$

sendo FC o fator de concentração para cada elemento analisado, este foi calculado pela seguinte expressão:

$$
F C=\frac{[\text { elemento }]_{i}}{[\text { elemento }]_{\text {base }}}
$$

sendo:

[elemento $_{i}$ a concentração do elemento na fatia $i$ do sedimento;

[elemento] $]_{\text {base }}$ a concentração do elemento na base do sedimento.

Quando o valor de PLI é igual a zero, caracteriza uma região não contaminada, valores de 0 a 1 indicam uma região com uma baixa poluição, para valores acima de 1 indicam uma proa deterioração do estuário (Tomlinson et al, 1980).

\section{Ecological Risk Index (RI)}

O Ecological Risk Index (RI) é um índice proposto por Hakanson (1980), utilizado para quantificar o potencial risco ecológico dos sedimentos, utilizando como base a toxicidade dos metais pesados. Foi criado norteado por pesquisas nos domínios de toxicidade biológica, química ambiental e ecologia. Os parâmetros são calculados de acordo com as equações:

$$
\begin{gathered}
E_{r i}=T_{r i} \times F C \\
R I=\sum_{i=1}^{n} E_{r i}
\end{gathered}
$$

onde: 
- $\quad F C$ é o Fator de Concentração da amostra;

- $\quad E_{r i}$ é o monômio do potencial fator de risco para cada metal;

- $\quad T_{r i}$ é o peso tóxico do metal.

$\mathrm{O}$ valor de $\mathrm{T}_{\text {ri }}$ é igual a 1 para $\mathrm{Zn}$, igual a 2 para $\mathrm{Cr}$, de 5 para $\mathrm{Cu}, \mathrm{Ni}$ e $\mathrm{Pb}$, igual a 10 para As e é de 40 para $\mathrm{Hg}$.

Os valores de RI e suas respectivas classificações são: RI inferiores a 150 correspondem a sedimentos com baixo risco ecológico, de 150 a 300 sedimentos com um risco moderado, de 300 a 600 sedimentos com risco considerável, acima de 600 os sedimentos são considerados de risco ecológico muito alto. 


\section{Análise de Resultados e Discussão Preliminar}

Serão apresentados nesse capítulo os resultados obtidos e a discussão preliminar baseadas nos parâmetros de qualidade dos sedimentos.

\subsection{Análise Granulométrica}

O testemunho Bertioga 1 apresentou uma coluna sedimentar homogênea com relação ao teor dos sedimento finos, com valores que oscilaram em torno de $65 \%$, como notou-se na Figura 6. Devido à dinâmica da região, o testemunho Bertioga 2 demonstrou os menores teores de sedimentos finos. Observa-se que os testemunhos Bertioga 3 e Bertioga 4 foram constituídos basicamente de sedimentos finos, com valores médios ao longo da coluna sedimentar em torno de $99 \%$.

Pôde-se notar uma grande acumulação de sedimentos finos no testemunho Bertioga 5, fato tal justificado pela sua localização. Observando a Figura 6, notou-se que o teor de sedimentos menores do que $0,062 \mathrm{~mm}$ diminuem gradativamente ao longo dos anos, com os menores valores (cerca de 77\%) presentes nas porções mais recentes do presente testemunho.

Os testemunhos Santos 1 e Santos 2, exemplificados na Figura 7, expressaram valores bastante semelhantes, fato tal que pôde ser explicado pela proximidade destes. De maneira geral, estes apresentaram teores elevados de sedimentos finos, podendo ser regiões propícias para o acúmulo de metais. Os testemunhos Santos 4 e Santos 8 mostraram valores intermediários de teores de sedimentos finos, com médias variando em torno de $50 \%$. Observando os gráficos, notou-se uma grande variação ao longo da coluna sedimentar. 

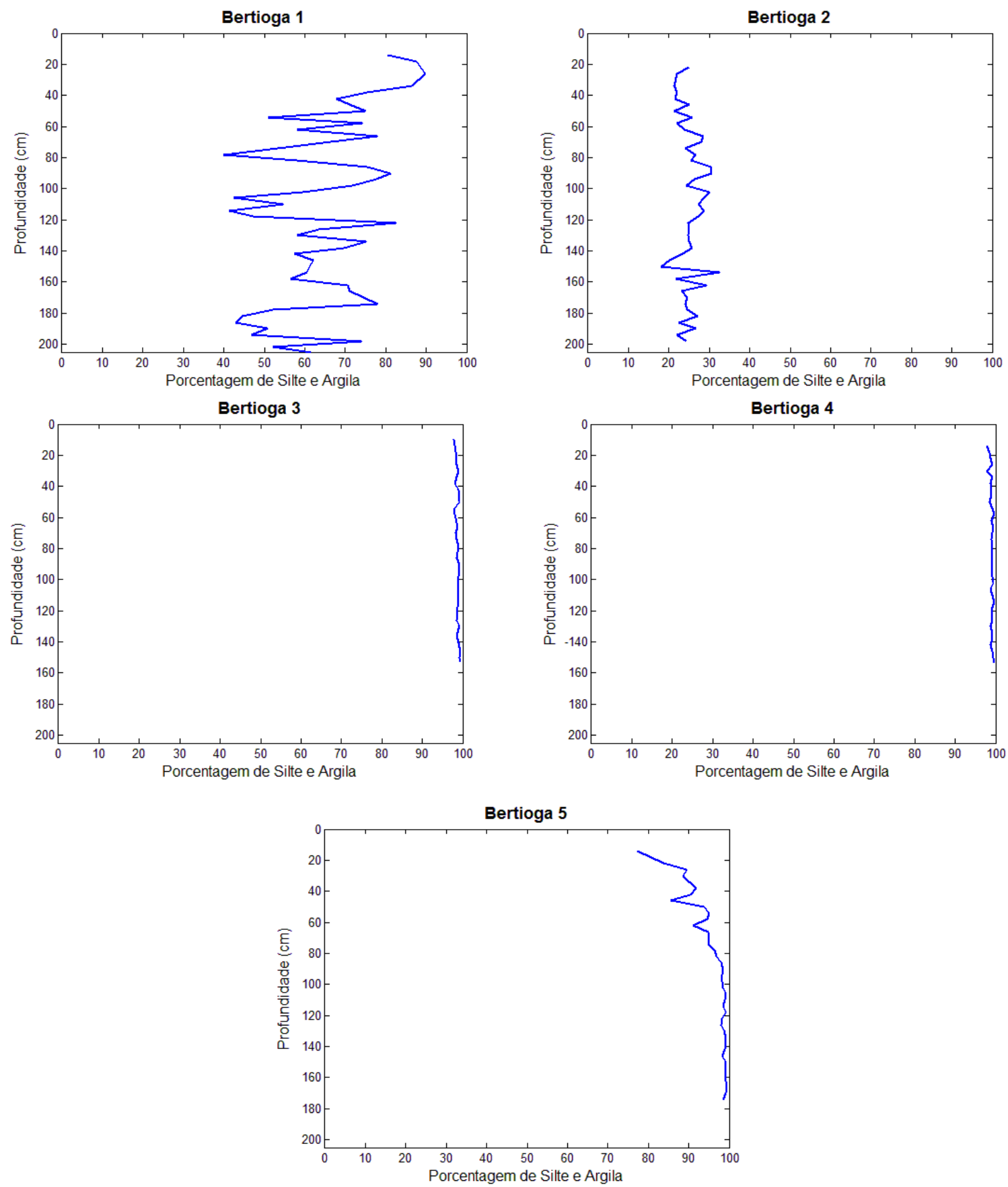

Figura 6. Teores de sedimentos finos nos testemunhos localizados no Canal de Bertioga 

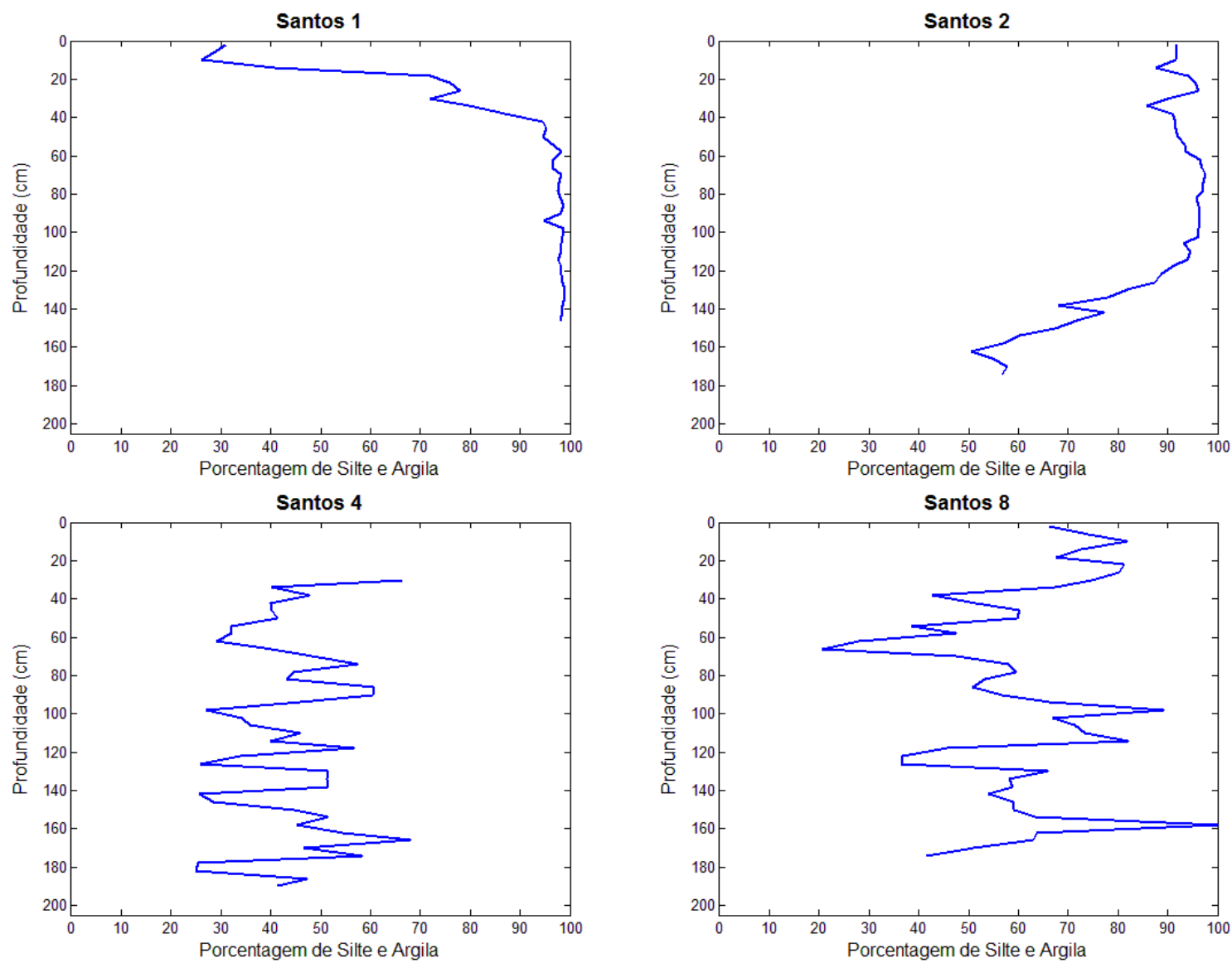

Figura 7. Teores de sedimentos finos nos testemunhos localizados em Santos.

\subsection{Carbono Orgânico Total (COT)}

Os valores de carbono orgânico (COT) total foram analisados para os primeiros 100 $\mathrm{cm}$ dos nove testemunhos estudados. Como observado na Figura 8, os perfis sedimentares Bertioga 2, Bertioga 3 e Bertioga 4 foram bastante semelhantes em relação ao teor de COT no sedimento. 

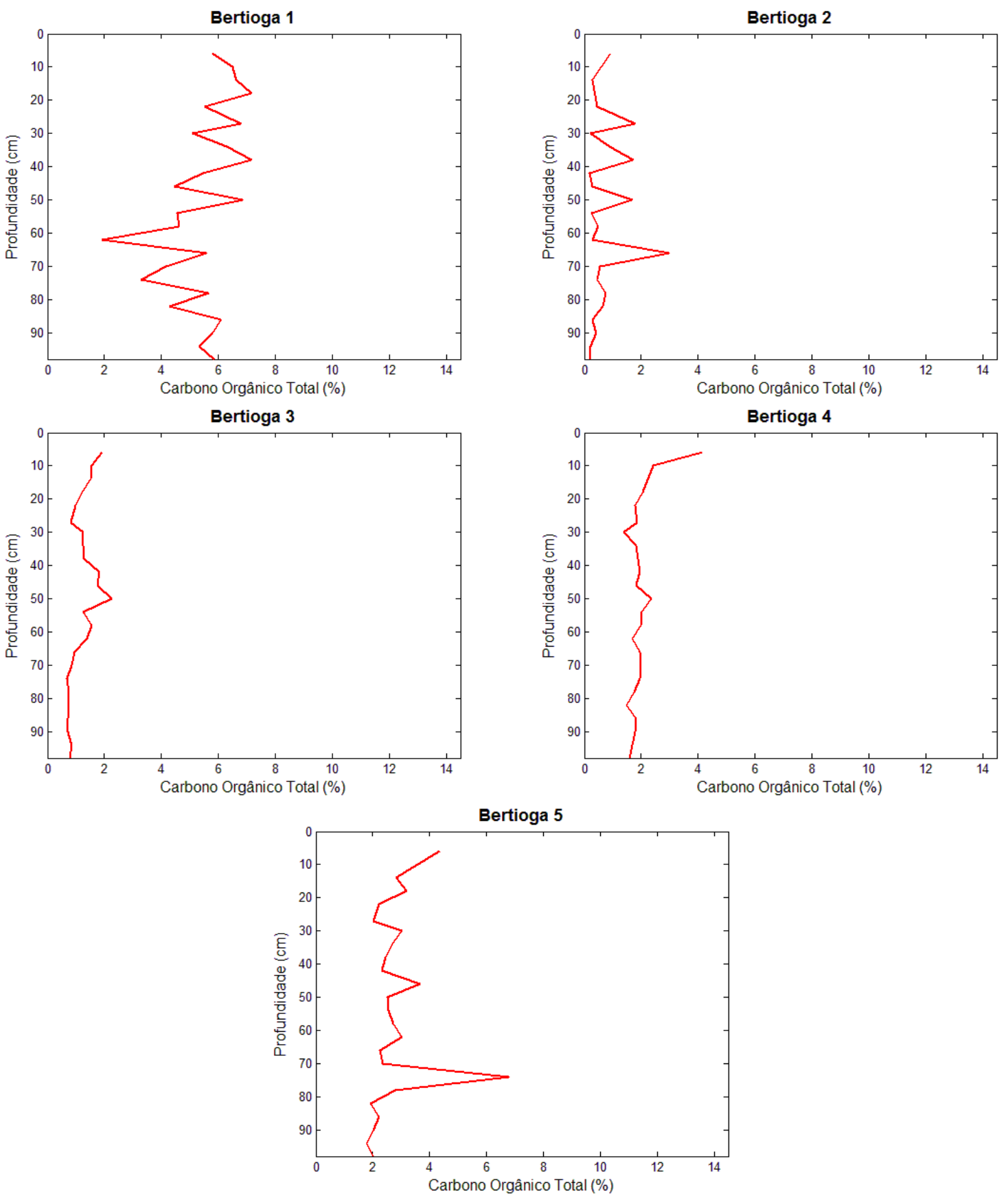

Figura 8. Valores de Carbono Orgânico Total (COT) para os testemunhos localizados no Canal de Bertioga.

O testemunho Bertioga 1 apresentou os maiores valores de COT dentre aqueles localizados no Canal de Bertioga. Já Bertioga 5, expressou uma coluna sedimentar homogênea, com valores em torno de $2 \%$.

Os testemunhos localizados no estuário santista, demonstrados na Figura 9, apresentaram um comportamento semelhante aos localizados no Canal de Bertioga. Santos 1 e Santos 2 expressou valores homogêneos ao longo da coluna sedimentar. O primeiro 
demonstrou valores médios de 1,6\%, já o segundo apresentou valores médios de 4,4\%. Santos 8 , embora tenha expressado pequenas variações ao longo da coluna sedimentar, possui valores médios de $3,84 \%$.

O testemunho Santos 4 apresentou um grande crescimento no teor de COT a partir da profundidade de $50 \mathrm{~cm}$. Os valores próximos ao topo alcançaram valores de 14,1\%. Esse significativo aumento nos últimos anos pôde ser explicado pelo crescente despejo de esgotos in natura no estuário. Na região a qual se localiza Santos 4, encontrou-se uma grande quantidade de palafitas, que acabam por contribuir como fonte de esgoto doméstico para o sistema.
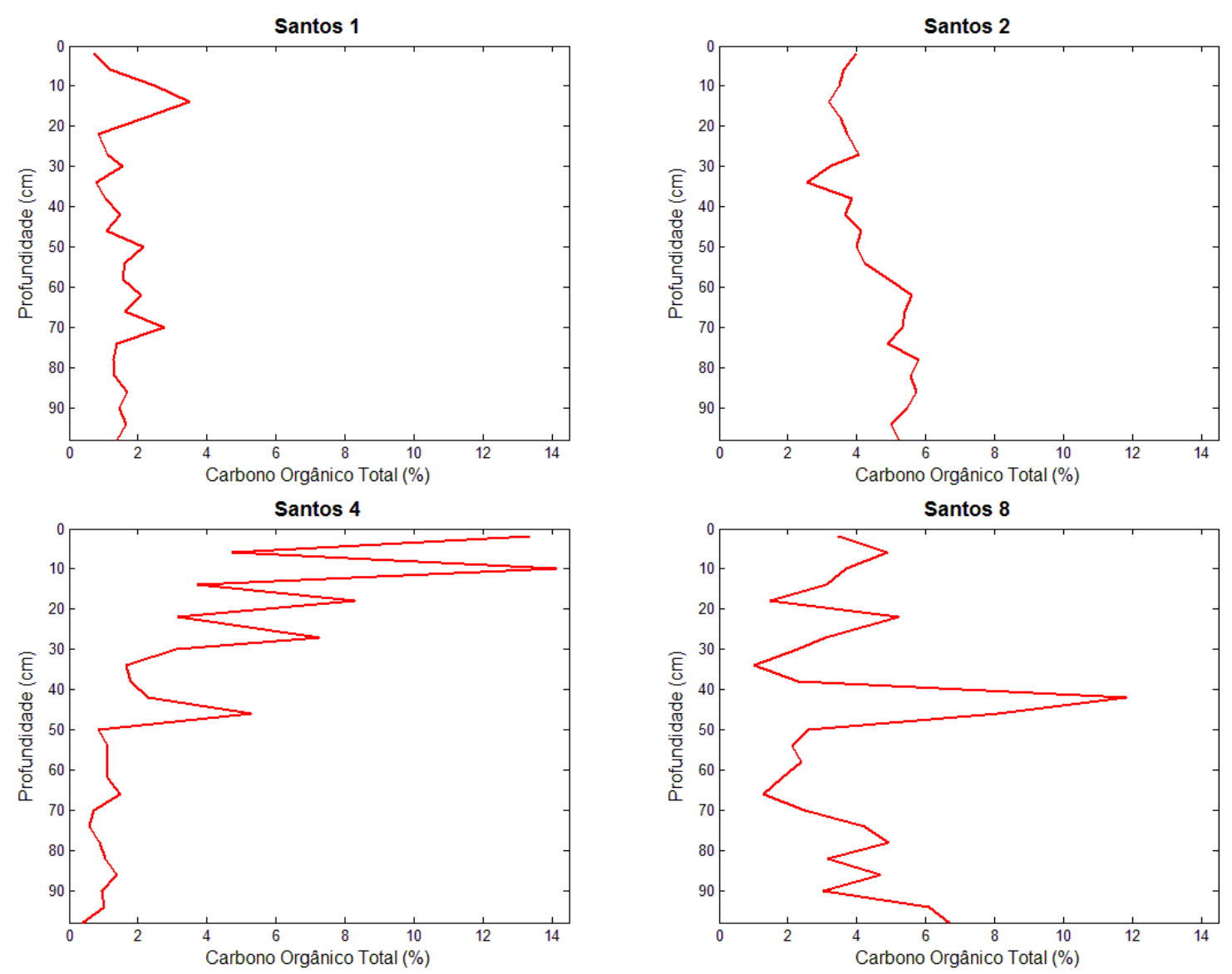

Figura 9. Valores de Carbono Orgânico Total (COT) para os testemunhos localizados em Santos.

Diversos trabalhos avaliaram o carbono orgânico no sedimento. Martins (2005) estudou carbono orgânico total em testemunhos localizados no estuário de Santos e São Vicente. Os valores obtidos se assemelharam aos encontrados no presente trabalho. Em um testemunho próximo à localização de Santos 2 encontraram-se valores próximos a 3,3\%, com 
máximos de 3,93\%. Siqueira et al. (2004) analisou carbono orgânico total no sedimento de fundo do estuário santista. Os valores médios obtidos foram de 3,0\% para o canal de Santos e 2,8\% para o canal de São Vicente. Quináglia (2006) avaliou os teores de COT em sedimentos de fundo do Canal de Bertioga. Os valores obtidos foram inferiores a $2 \%$.

\subsection{Suscetibilidade Magnética}

Os perfis de suscetibilidade magnética podem ser observados na Figura 10 e Figura 11. De maneira geral, os testemunhos localizados no Canal de Bertioga apresentaram valores de suscetibilidade magnética semelhantes, variando próximos a 4 .

Os testemunhos localizados em Santos demonstraram um padrão distinto dos anteriores, como nota-se na Figura 11. Santos 1 e Santos 4 expressaram características semelhantes, sendo homogêneos ao longo da coluna sedimentar. Santos 2 possuiu um grande aumento na porção próxima a superfície, com valores próximos a 20. 

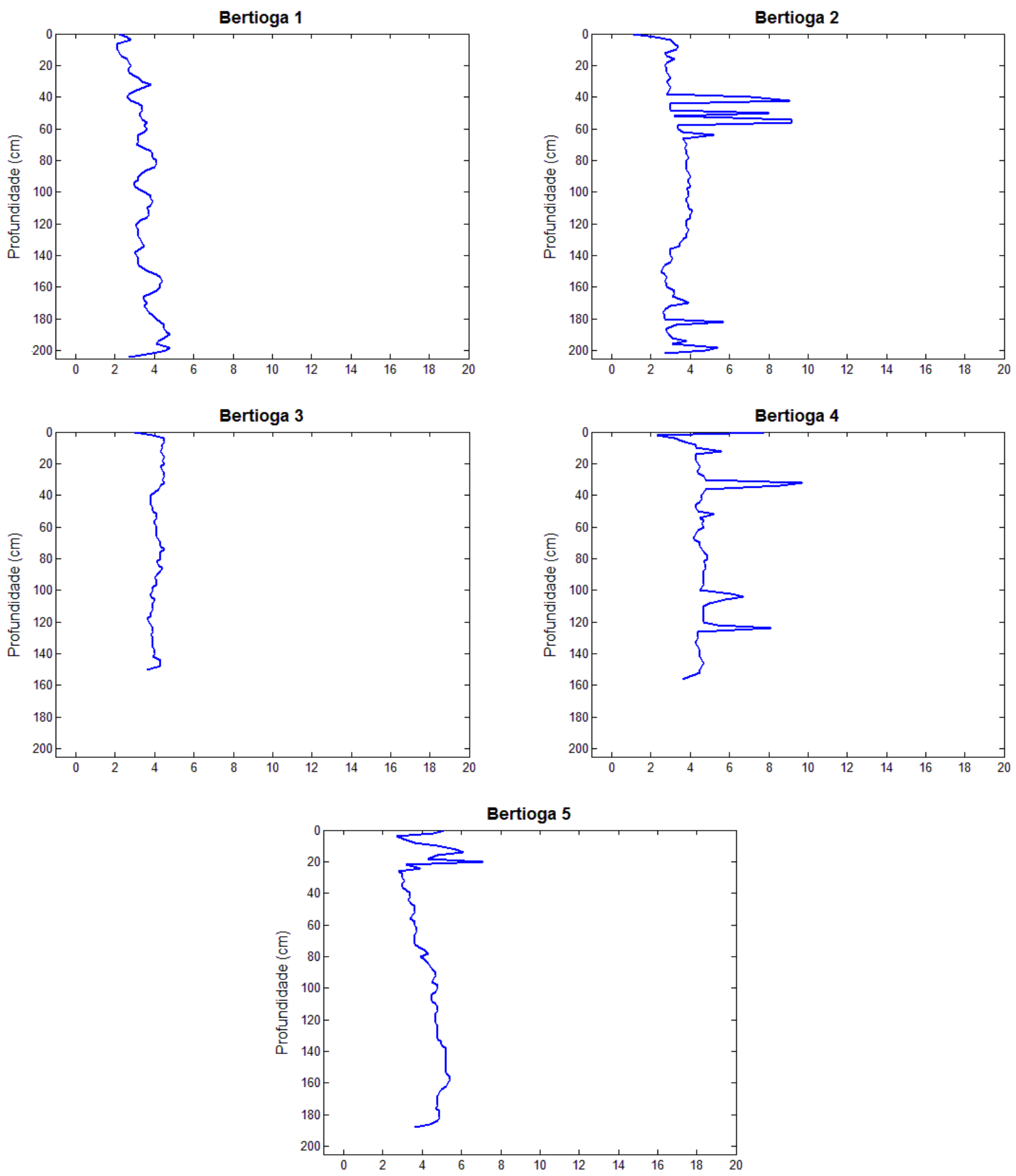

Figura 10. Perfil de Susceptibilidade Magnética para os testemunhos de Bertioga.

Santos 8 demonstrou características peculiares. Como observado na Figura 11, houve um grande aumento na porção superior da coluna sedimentar, acima dos primeiros $20 \mathrm{~cm}$. Os valores obtidos nessa porção foram aproximadamente vinte vezes maiores do que aqueles encontrados nas demais colunas sedimentares, podendo indicar um grande acúmulo de metais nessas camadas. 
Foi possível notar uma tendência de acúmulo de metais, na porção superficial para os testemunhos Santos 2 e Santos 8. Os demais não apresentaram padrão visível. Analisando os valores obtidos, Santos 8 tendeu a apresentar as maiores concentrações de metais.

Comparando os perfis de suscetibilidade magnética com os de teores de sedimentos finos, apresentados na seção 6.1, notamos que houve uma grande semelhança entre eles. Esse padrão não é observado para os testemunhos Santos 2 e Santos 8. Estes, por sua vez, expressaram as maiores concentrações de metais. O perfil de suscetibilidade magnética para esses foi bastante similar aos perfis de concentração de metais observados.
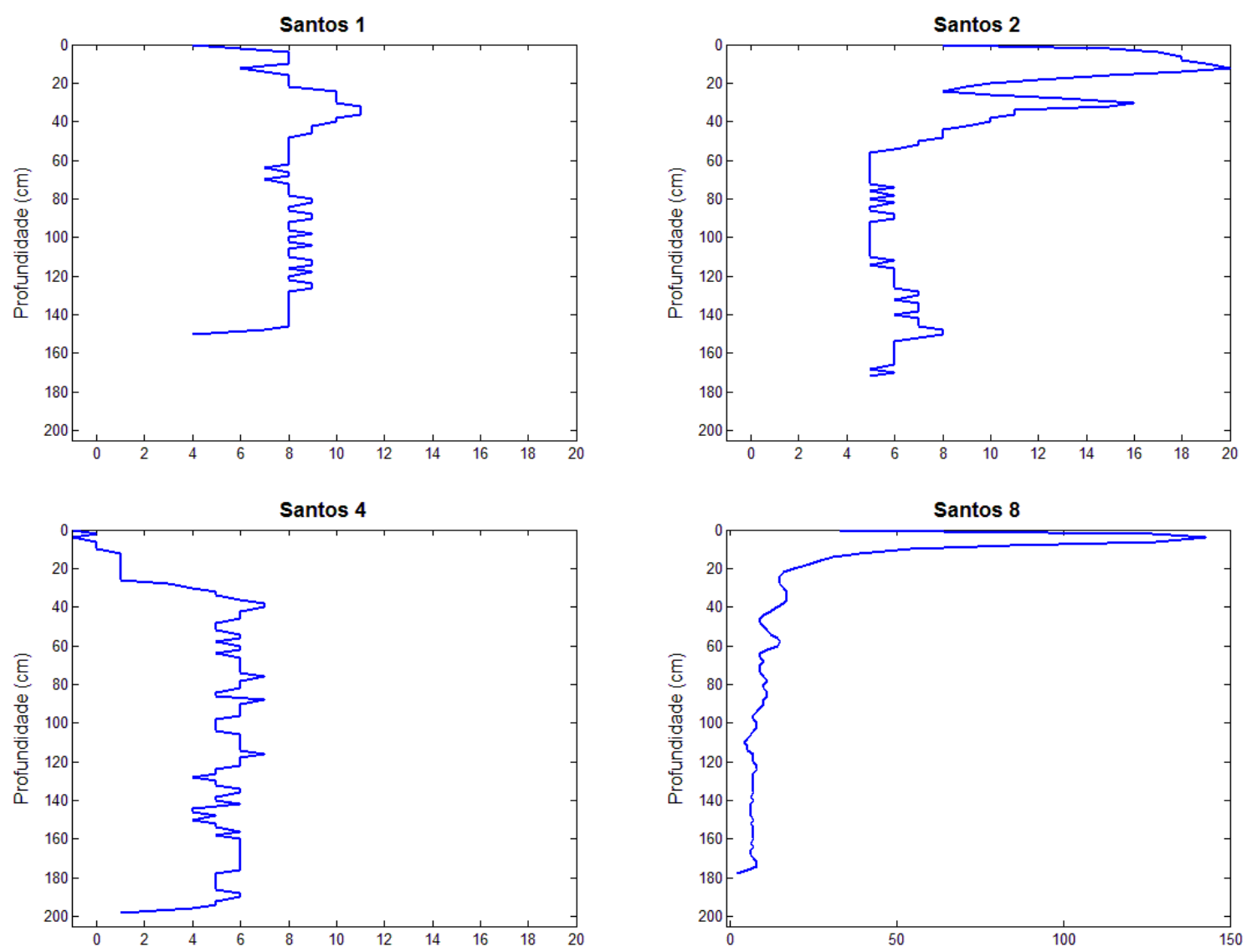

Figura 11. Perfil de Susceptibilidade Magnética para os testemunhos de Santos.

\subsection{Datação}

A fim de estimar as idades das amostras estudadas para uma possível comparação entre os resultados e eventos históricos, foram calculadas as taxas de sedimentação, apresentadas na Tabela 5. 
Tabela 5. Taxas de sedimentação baseadas no modelo CIC para os testemunhos estudados.

\begin{tabular}{l|c|} 
& Taxa sedimentação $(\mathbf{c m} / \mathbf{a n o})$ \\
\hline Bertioga 1 & $0,84 \pm 0,06$ \\
Bertioga 2 & $1,12 \pm 0,09$ \\
Bertioga 3 & $1,26 \pm 0,12$ \\
Bertioga 4 & $0,97 \pm 0,07$ \\
Bertioga 5 & $0,93 \pm 0,15$ \\
Santos 1 & $1,30 \pm 0,04$ \\
Santos 2 & $1,11 \pm 0,04$ \\
Santos 8 & $0,83 \pm 0,04$
\end{tabular}

A partir dos valores de taxas de sedimentação puderam ser estimadas as idades de cada porção da coluna sedimentar. A datação das amostras foi calculada a partir da seguinte equação:

$$
D=A_{0}-\frac{z}{v}
$$

onde:

- $\quad D$ é o ano de deposição (datação) da camada;

- $A_{0}$ corresponde ao ano de coleta do testemunho;

- $\quad z$ é a profundidade da camada;

- $\quad v$ é a taxa de sedimentação.

Os respectivos valores de datação obtidos podem ser encontrados ao longo do trabalho, apresentados nos gráficos dos perfis sedimentares descritos nas seções a seguir.

\subsection{Análises Químicas}

\subsubsection{Digestão parcial de sedimento para a análise de metais e semimetais}


O grau de contaminação química foi avaliado a partir nos valores estabelecidos pelo “Canadian Environmental Quality Guidelines” (CEQG, 2001), para metais pesados e são expressos na Tabela 6. No caso do semimetal arsênio, optou-se por orientar-se, também, nos valores estabelecidos pela Resolução Conama, 454 (2012).

Baseado nos efeitos dos elementos mencionados sob a biota, o menor limite- TEL (Threshold Effect Level) ou Nível 1- representa a concentração abaixo da qual raramente são esperados efeitos adversos para os organismos. O maior limite - PEL (Probable Effect Level) ou Nível 2 - representa a concentração acima da qual é frequentemente esperado o citado efeito adverso para os organismos. Na faixa entre TEL (Nível 1) e PEL (Nível 2) situam-se os valores onde ocasionalmente espera-se tais efeitos.

Tabela 6. Valores de concentração orientadores (em $\mathrm{mg} / \mathrm{kg}$ ) para metais e As.

\begin{tabular}{|l|c|c|c|c|}
\hline Metais e Metalóides & TEL (Nível 1) & PEL (Nível 2) $^{\mathbf{1}}$ & Nível 1 $^{\mathbf{2}}$ & Nível 2 $^{\mathbf{2}}$ \\
\hline Arsênio & 5,9 & 17 & 19 & 70 \\
Chumbo & 35 & 91,3 & 46,7 & 218 \\
Cobre & 35,7 & 197 & 34 & 270 \\
Cromo & 37,3 & 90 & 81 & 370 \\
Mercúrio & 0,17 & 0,486 & 0,3 & 1,0 \\
Níquel & 18 & 35,9 & 20,9 & 51,6 \\
Zinco & 123 & 315 & 150 & 410 \\
\hline
\end{tabular}
1. Valores estabelecidos pelo “Canadian Environmental Quality Guidelines”.

2. Valores estabelecidos na Resolução Conama, $n^{\circ} 454,2012$.

\section{Alumínio (Al), Ferro (Fe), Manganês (Mn), Escândio (Sc) e Vanádio (V)}

Os elementos $\mathrm{Al}, \mathrm{Fe}, \mathrm{Sc}$ e V apresentaram comportamento semelhante aos perfis de teor de sedimentos finos, indicando uma forte associação entre os metais em questão e o parâmetro físico granulometria. Já o elemento Mn, por não ser considerado um contaminante, não foi discutido. Os gráficos de concentração desses elementos são apresentados no Anexo 1 .

\section{Arsênio (As)}

O arsênio apresenta características muito peculiares na costa brasileira. As legislações internacionais apresentam baixos limites para esse semimetal. Até o ano de 2012, todas as legislações vigentes no Brasil, baseadas em valores internacionais, possuíam limites baixos para esse elemento. Baseadas em estudos de As na costa brasileira, a Resolução 
Conama 454, foi aprovada em 2012, levando em considerações limites de As coerentes com os valores de background observados.

Serão aqui avaliados os valores de As baseados em duas legislações: os valores de agência ambiental canadense de TEL e PEL, e a Resolução Conama 454 (2012). A Figura 12 e Figura 13 apresentam os perfis de As observados nos nove testemunhos estudados, contrapostos com os valores das duas legislações.

Bertioga 1 apresentou valores variando em torno de $9 \mathrm{mg} / \mathrm{kg}$. Observou-se uma homogeneidade ao longo da coluna sedimentar, não sendo evidenciadas camadas de acréscimo ou decréscimo de concentrações. Com relação aos valores de legislação, notou-se que o testemunho como um todo, expressou valores superiores ao limite TEL- Nível 1 estabelecido pela agência ambiental canadense. No entanto, esses valores encontraram-se muito abaixo dos limites de PEL-Nível 2 e de Nível 1 da Resolução Conama 454.

O testemunho Bertioga 2 apresentou os menores valores de concentração de As. Esse fato pôde ser justificado pela granulometria das amostras. Essa coluna sedimentar apresentou ou menores teores de sedimentos finos com relação a todos os testemunhos estudados. Assim como em Bertioga 1, a coluna sedimentar demonstrou-se homogênea em toda sua extensão. Seus valores oscilaram em torno de $6 \mathrm{mg} / \mathrm{kg}$.

Bertioga 3 demonstrou valores de concentração de As mais próximos ao segundo limiar da legislação da agência ambiental canadense, não chegando a ultrapassá-los, assim como o primeiro valor da Resolução Conama 454. Não foi possível se observar períodos de aumento na concentração ao longo da coluna sedimentar, tendendo a um padrão homogêneo de distribuição.

O testemunho Bertioga 4 apresentou características semelhantes ao anterior. Os valores médios de concentração oscilaram em torno de $14 \mathrm{mg} / \mathrm{kg}$. No entanto, observou-se próximo à superfície um leve aumento nas concentrações, com valores de topo superiores ao PEL, porém inferiores ao Nível 1 da Resolução Conama 454.

Bertioga 5 demonstrou os maiores valores de As dentre os testemunhos estudados. Observou-se um padrão de concentração em toda a coluna sedimentar diferente dos demais testemunhos. O perfil demonstrou concentrações com crescimento continuo da base ao topo do testemunho. As concentrações encontraram-se nos primeiros $60 \mathrm{~cm}$ (período estimado: 1940-2010) acima do limite PEL, estando, em alguns pontos, acima do Nível 1 da Resolução Conama anteriormente citada. 

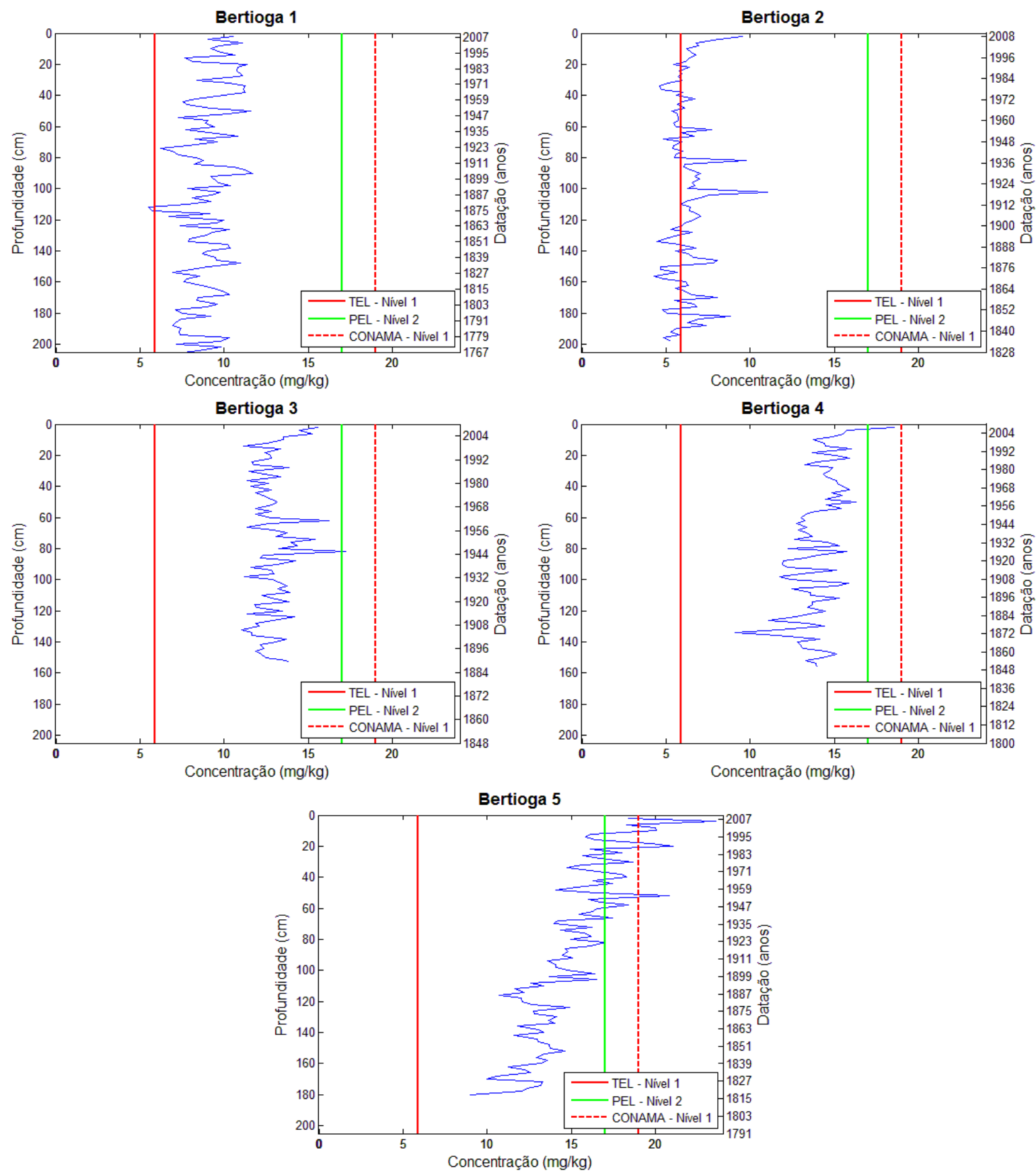

Figura 12. Valores de concentração de As ( $\mathrm{mg} / \mathrm{kg}$ ) para os testemunhos localizados no Canal de Bertioga.

Os sedimentos do testemunho Santos 1 apresentaram um aumento na concentração de As da base até os $70 \mathrm{~cm}$ de profundidade (período estimado: 1900 -1945), Há uma homogeneidade das amostras na camada de 35 a 70cm (período estimado: 1945-1990), sofrendo uma grande queda nos primeiros $35 \mathrm{~cm}$. O grande decréscimo na porção superficial possivelmente esteve relacionado aos baixos teores de sedimentos finos nessas camadas. 
Santos 2 expressou valores de concentração de As variando em torno de $12 \mathrm{mg} / \mathrm{kg}$. Notou-se, observando a Figura 13, um decréscimo do teor do semimetal ao longo dos últimos anos, evidenciado a partir da profundidade de $40 \mathrm{~cm}$ (data estimada: 1978), em direção ao topo. Os $80 \mathrm{~cm}$ que se seguem abaixo dessa profundidade (até aproximadamente $120 \mathrm{~cm}$, data estimada: 1905) sofreram também queda mais atenuada na concentração. Comparando os valores obtidos com as legislações vigentes, observou-se que todos os pontos encontraram-se acima de TEL-Nivel 1. No entanto, ainda estão abaixo do PEL-Nível 2 e Nivel 1 da Resolução Conama.

O testemunho Santos 4, embora tenha apresentado as menores concentrações de As entre aqueles amostrados em Santos, demonstrou um aumento significativo nos primeiros 60 $\mathrm{cm}$ da coluna sedimentar. Os valores apresentados oscilam, em sua maioria, em torno de 6 $\mathrm{mg} / \mathrm{kg}$, estando parte abaixo e parte acima do TEL-Nível 1, não chegando a atingir PEL-Nível 2 em nenhum ponto.

Santos 8 apresenta pequenas variações ao longo da coluna sedimentar. Observou-se uma camada de mínimas concentrações próximas à profundidade de $60 \mathrm{~cm}$ (data estimada: 1940), acima desta houve um aumento em direção ao topo, abaixo notou-se um acréscimo nos teores de As em direção à base do testemunho. Comparando o perfil de concentração de As com os teores de sedimentos finos (seção 5.1), notou-se grande semelhança, podendo indicar uma forte associação entre o teor de silte e argila e a acumulação do semimetal em questão. A análise de correlação entre os dois parâmetros apresentaram valores de 'p' inferiores a 0,05 , indicando correlação significativa entre eles. 

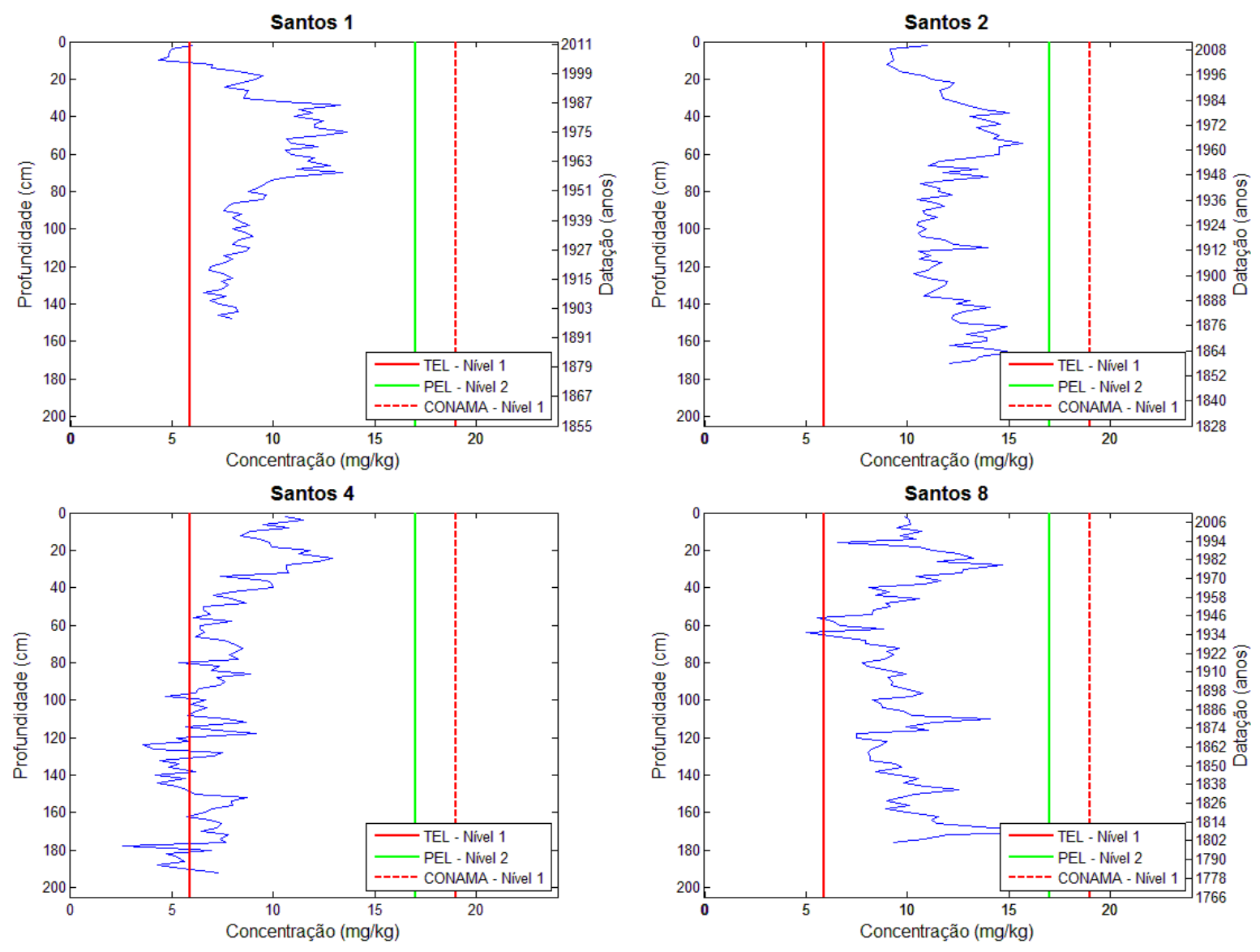

Figura 13. Valores de concentração de As (mg/kg) para os testemunhos localizados em Santos.

\section{Cromo (Cr)}

A Figura 14 e Figura 15 apresentam os valores de concentração de Cr entre os testemunhos estudados. Não houve grandes variações entre os padrões aparentes das colunas sedimentares localizadas no Canal de Bertioga e daquelas localizadas em Santos.

O testemunho Bertioga 1 apresentou concentrações homogêneas ao longo da coluna sedimentar. Pôde-se observar um pequeno acréscimo nas porções mais recentes. As concentrações variaram entre 20 e $35 \mathrm{mg} / \mathrm{kg}$, estando abaixo do limiar o qual se prevê efeitos adversos a biota.

Bertioga 2 apresentou as menores concentrações de $\mathrm{Cr}$ dentre os testemunhos estudados. Os teores do metal variaram entre 10 e $15 \mathrm{mg} / \mathrm{kg}$ na maior parte da coluna sedimentar. Houve um pequeno decréscimo dos valores nas camadas abaixo dos $140 \mathrm{~cm}$, variando em torno de $9 \mathrm{mg} / \mathrm{kg}$.

Os valores de $\mathrm{Cr}$ do testemunho Bertioga 3 foram um pouco mais elevados do que os descritos anteriormente. As concentrações oscilaram em torno de $37 \mathrm{mg} / \mathrm{kg}$ em grande parte 
da coluna sedimentar. Sabendo que o valor de Nível 1 estabelecido em legislação é de 37,3 $\mathrm{mg} / \mathrm{kg}$, observou-se que boa parte das amostras ocasionalmente ofereceria efeito adverso à biota local. Houve uma queda na concentração nos primeiros $40 \mathrm{~cm}$ da coluna sedimentar (período estimado: 1980-2010).

Bertioga 4 demonstrou pequenas variações ao longo da coluna sedimentar. Houve um acréscimo na concentração de $\mathrm{Cr}$ do topo até a profundidade de $80 \mathrm{~cm}$ (data estimada: 1932). Os valores nessa porção do testemunho variaram de 30 a $45 \mathrm{mg} / \mathrm{kg}$. Grande parte das amostras nesse intervalo encontraram-se acima do Nível 1 da legislação. Houve uma queda nas concentrações entre as profundidades de 90 e $120 \mathrm{~cm}$ (datas estimadas: 1890 - 1915), aumentando novamente desse ponto em direção à base do testemunho.

Novamente, o testemunho Bertioga 5 apresentou um perfil de concentração de $\mathrm{Cr}$ semelhante àquele apresentado em Bertioga 3. No entanto, as concentrações observadas no primeiro foram mais elevadas daquelas notadas no segundo. Foi possível observar um acréscimo nas concentrações abaixo da profundidade de $10 \mathrm{~cm}$ (data estimada: 2001). Todas as amostras abaixo desta data encontraram-se acima do primeiro limite da legislação vigente.

Santos 1 expressou como característica um decréscimo nas concentrações em direção ao topo do testemunho. As concentrações nesse ponto oscilaram de 11 a $34 \mathrm{mg} / \mathrm{kg}$, estando abaixo do Nível 1 em toda a extensão da coluna sedimentar. Observando os valores de sedimentos finos apresentados na seção 6.1, notou-se que houve grande semelhança entre os dois perfis, indício de que esse metal possa estar associado à esse parâmetro.

O testemunho Santos 2 apresentou pequena variação com relação à concentração de Cr. Os valores obtidos variaram próximos ao limiar acima do qual observa-se ocasionalmente efeitos adversos à biota. Notou-se um pequeno acréscimo nas porções mais superficiais do testemunho, estando estas acima do Nível 1 da legislação.

Santos 4 demonstrou um padrão semelhante ao observado para os teores de sedimentos finos. Houve uma grande oscilação ao longo da coluna sedimentar (os valores oscilaram entre 10 e 30 mg/kg), no entanto, não observou-se um padrão aparente indicando acréscimo ou decréscimo das concentrações ao longo dos anos.

Santos 8 apresentou claramente um ponto de inflexão próximo à profundidade de 64 cm (data estimada: 1935). Houve um acréscimo nas concentrações de $\mathrm{Cr}$ deste ponto em direção ao topo do testemunho, da mesma forma que ocorreu um acréscimo nas concentrações em direção à base do testemunho, até aproximadamente $98 \mathrm{~cm}$ de profundidade (data 
estimada: 1894). Abaixo desta profundidade aconteceu novamente um decréscimo nos teores de $\mathrm{Cr}$ em direção à base do testemunho.
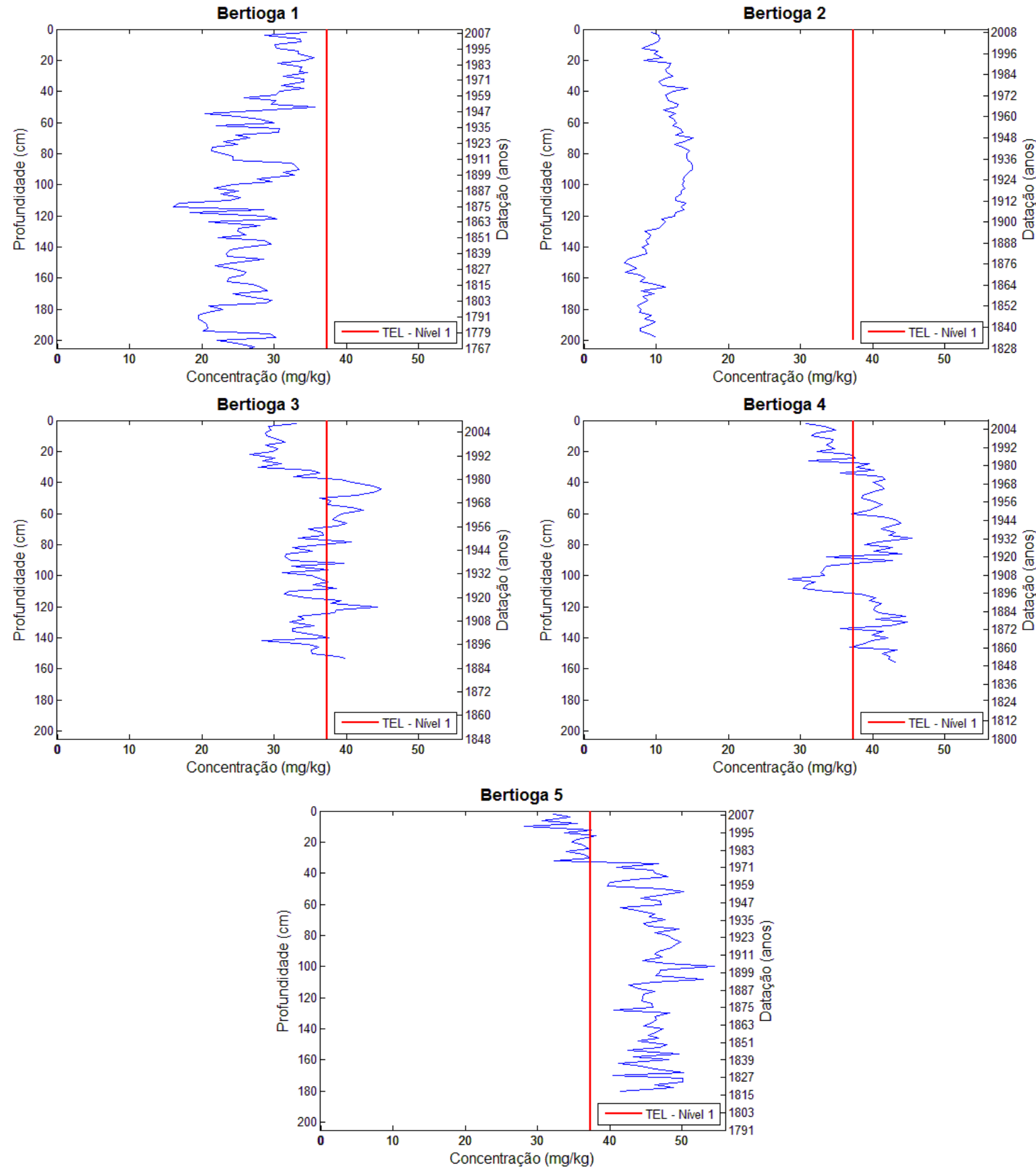

Figura 14. Valores de concentração de Cr ( $\mathrm{mg} / \mathrm{kg})$ para os testemunhos localizados no Canal de Bertioga. 

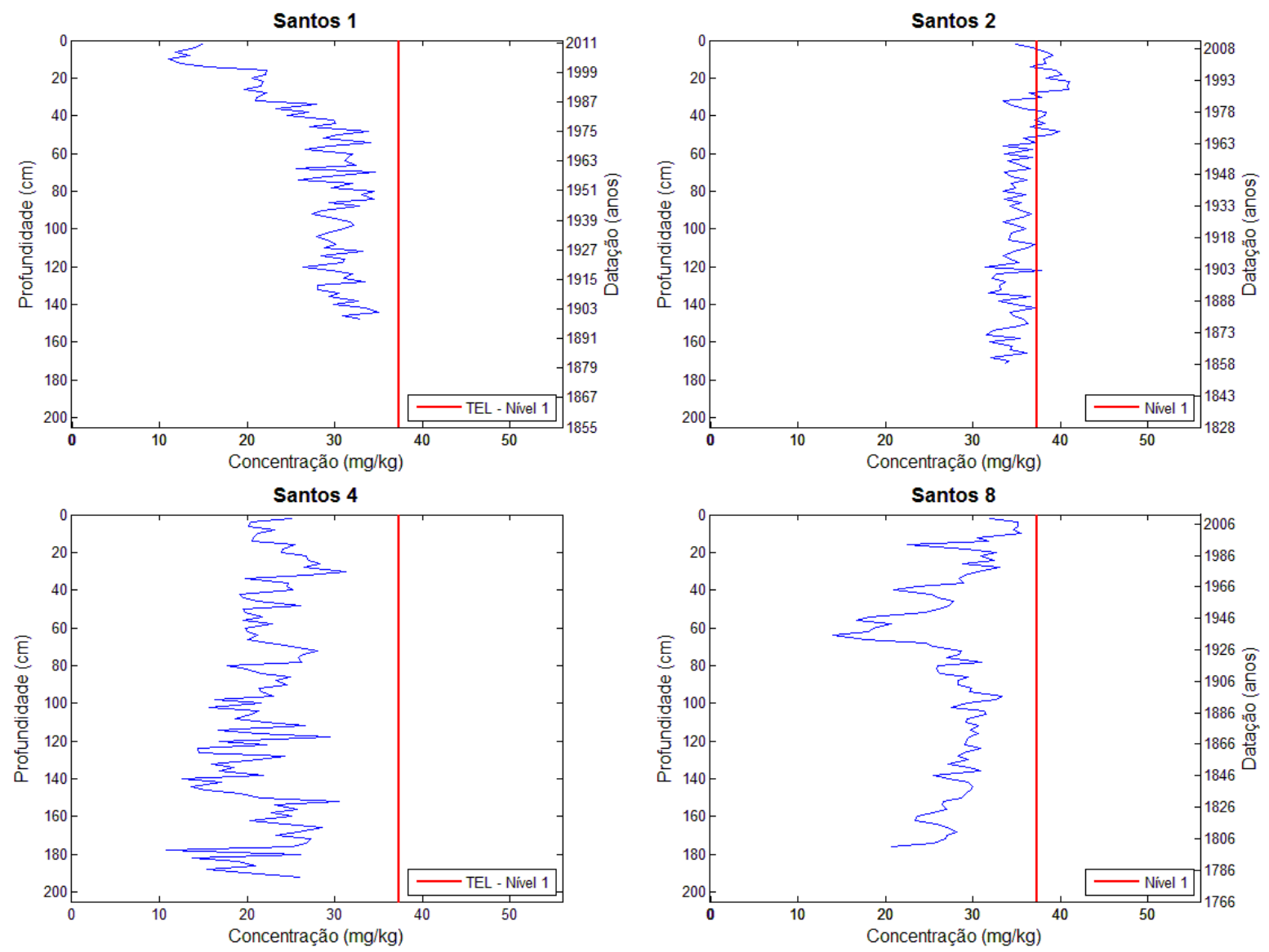

Figura 15. Valores de concentração de Cr $(\mathrm{mg} / \mathrm{kg})$ para os testemunhos localizados em Santos.

\section{Cobre (Cu)}

A Figura 16 e Figura 17 apresentam os valores de concentração de $\mathrm{Cu}$ para as colunas sedimentares estudadas. De maneira geral, os valores de $\mathrm{Cu}$ apresentados para os testemunhos localizados no Canal de Bertioga expressaram concentrações inferiores àquelas observadas em Santos. Comparando os valores obtidos com os valores legisladores, notou-se que os testemunhos estudados demonstraram baixas concentrações desse elemento.

Os testemunhos localizados no Canal de Bertioga apresentaram valores homogêneos ao longo da coluna sedimentar. Variando entre si apenas no que se diz respeito às médias das concentrações. Entre eles, os maiores valores foram observados em Bertioga 5, com médias de 9,5 mg/kg, seguidos por Bertioga 4, que apresentou concentrações médias de 9,0 mg/kg. Os testemunhos Bertioga 1 e Bertioga 3 demonstraram padrões semelhantes, com concentrações médias de 7,2 mg/kg e 7,7 mg/kg, respectivamente. Os menores valores de $\mathrm{Cu}$ foram encontrados no testemunho Bertioga 2, com valores médios de 2,5 mg/kg 

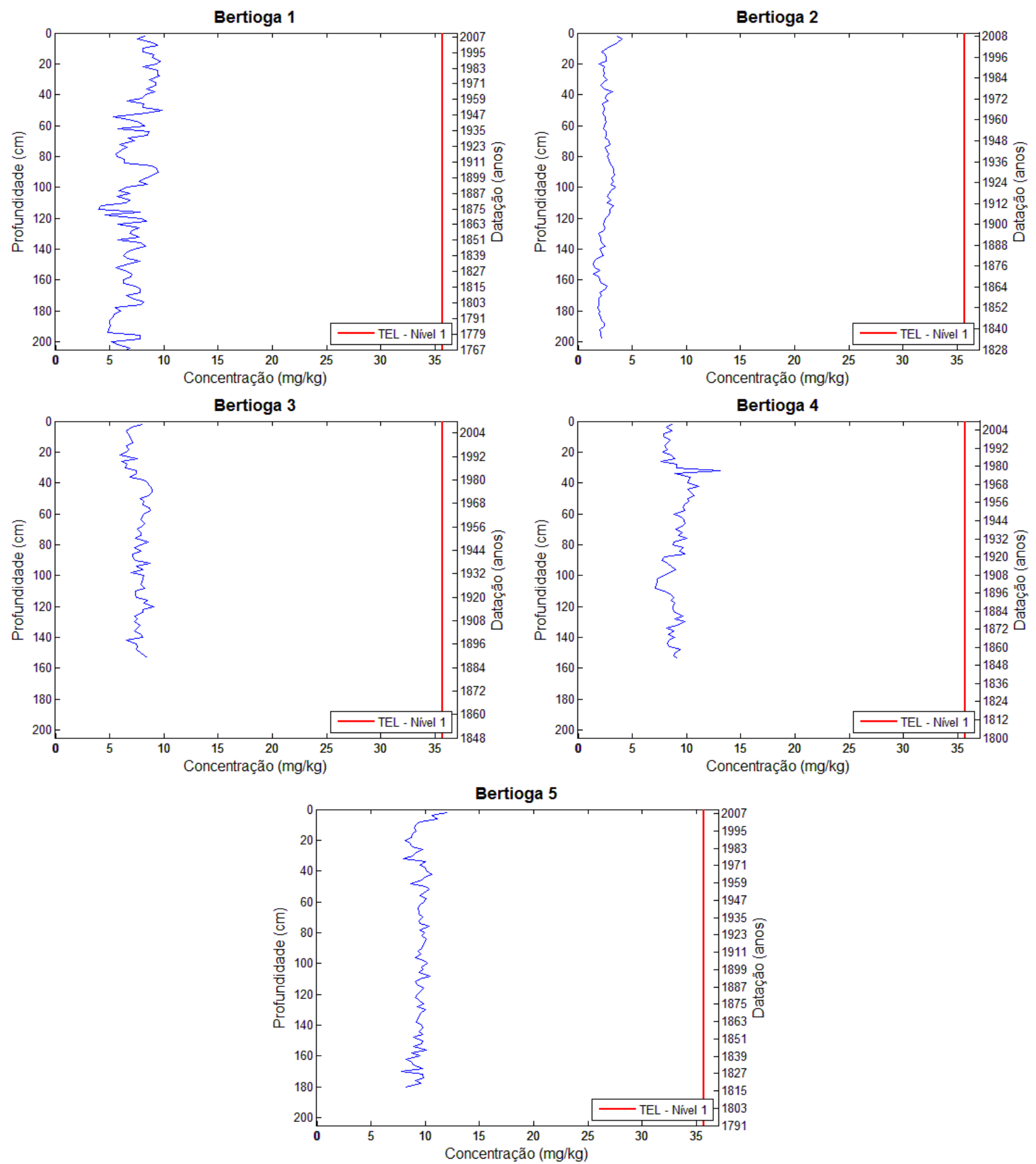

Figura 16. Valores de concentração de $\mathrm{Cu}(\mathrm{mg} / \mathrm{kg})$ para os testemunhos localizados no Canal de Bertioga.

Embora os teores de $\mathrm{Cu}$ no testemunho Santos 1 tenham apresentado valores similares ao longo da coluna sedimentar, observou-se um pico de baixas concentrações entre 20 e $40 \mathrm{~cm}$ de profundidade (período estimada: 1983 -1998). O valor mínimo pôde ser observado na profundidade de $28 \mathrm{~cm}$ (data estimada: 1992). Os valores médios expressos em toda coluna sedimentar variam em torno de $7,6 \mathrm{mg} / \mathrm{kg}$. 
O testemunho Santos 2 apresentou concentrações de $\mathrm{Cu}$ mais elevadas, com relação aos demais analisados. $\mathrm{O}$ perfil sedimentar demonstrou um elevado aumento do teor de $\mathrm{Cu}$ nas camadas entre 10 e $60 \mathrm{~cm}$ de profundidade (período estimado:1958 -2005), sofrendo um pequeno decréscimo nos últimos $10 \mathrm{~cm}$. Embora o crescimento tenha sido bastante significativo, não atingiu o valor de TEL-Nível 1. Observando os teores de sedimentos finos, notou-se que houve uma baixa relação entre a concentração de $\mathrm{Cu}$ e esse parâmetro. Esse fato, somado à data a partir da qual o crescimento é observado (que coincide com o início da industrialização da região), sugeriu que o aumento nas concentrações foram reflexos da influência humana no ambiente.

Santos 4 apresentou características muito semelhantes àquelas observadas nos testemunhos localizados no Canal de Bertioga, no entanto, constatou-se uma pequena tendência de aumento nas concentrações de $\mathrm{Cu}$ nas porções mais próximas ao topo (a partir dos $40 \mathrm{~cm}$ de profundidade). Embora esse ponto esteja um pouco mais afastado dos grandes potenciais focos de contaminação do estuário santista, esse aumento pôde indicar uma leve influencia antrópica na região. Os valores médios de $\mathrm{Cu}$ nesse testemunho variaram em torno de $5,8 \mathrm{mg} / \mathrm{kg}$.

Semelhante ao testemunho Santos 2, Santos 8 evidenciou um grande aumento nas concentrações de $\mathrm{Cu}$ a partir da profundidade de $60 \mathrm{~cm}$ (data estimada: 1940). Devido à proximidade desse ponto com o polo industrial de Cubatão, esse significativo aumento pôde ser reflexo da industrialização da região. 

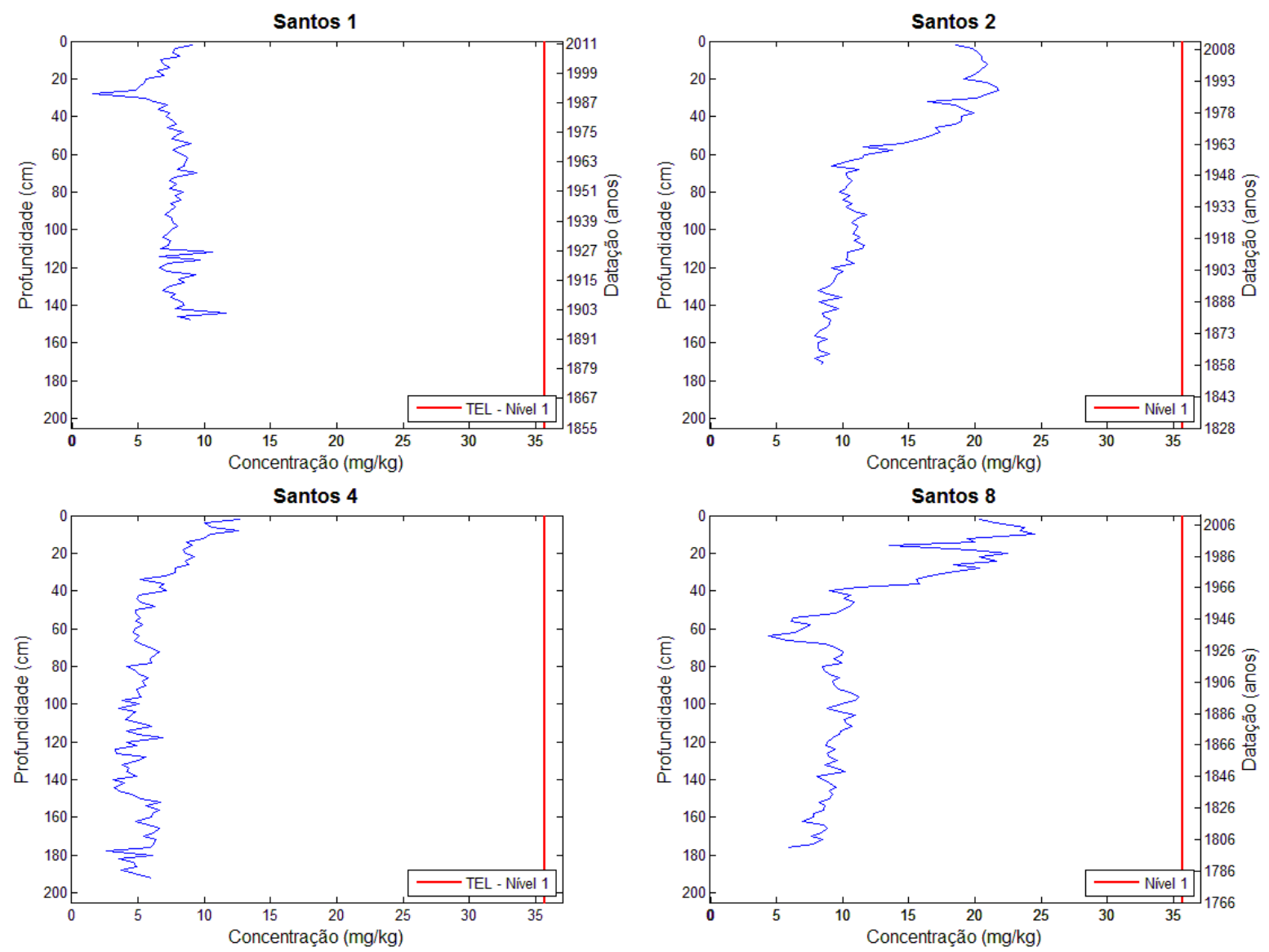

Figura 17. Valores de concentração de Cu $(\mathrm{mg} / \mathrm{kg})$ para os testemunhos localizados em Santos.

\section{Mercúrio (Hg)}

As Figura 18 e Figura 19 apresentaram os valores de $\mathrm{Hg}$ nas colunas sedimentares localizadas no Canal de Bertioga e Santos. Observou-se claramente a diferença entre os dois ambientes. Aqueles localizados no Canal de Bertioga evidenciaram baixos valores quando comparados aos testemunhos de Santos.

Bertioga 1 apresentou valores homogêneos de concentração de $\mathrm{Hg}$ ao longo da coluna sedimentar. Seus valores médios oscilaram em torno de $0,027 \mathrm{mg} / \mathrm{kg}$. Toda a coluna sedimentar demonstrou valores abaixo dos valores de legislação. O mesmo ocorreu para Bertioga 2, o testemunho expressou valores médios em torno de 0,021 mg/kg. No entanto, observou-se nesse caso um leve aumento nas porções superficiais do testemunho, acima dos $10 \mathrm{~cm}$ de profundidade (data estimada: 2003).

Bertioga 3 apresentou, assim como Bertioga 4, coluna sedimentar com pequenas variações. Notou-se, no entanto, que os valores médios de Bertioga 4 (média de concentrações de $0,027 \mathrm{mg} / \mathrm{kg}$ ) foram superiores aos de Bertioga 3 (média de concentrações de 0,017 
$\mathrm{mg} / \mathrm{kg}$ ). Diferenciou-se os dois testemunhos pelo pequeno acréscimo no teor de $\mathrm{Hg}$ na porção superficial de Bertioga 4. Ambos os testemunhos apresentaram concentrações inferiores o limite de TEL-Nível 1.

O testemunho Bertioga 5, embora tenha demonstrado baixas concentrações de $\mathrm{Hg}$, apresentou um padrão diferente das demais colunas sedimentares localizadas no Canal de Bertioga. Observou-se uma coluna sedimentar relativamente homogênea da profundidade de $18 \mathrm{~cm}$ (data estimada: 1993) até a base. No entanto, próximo ao topo houve um aumento significativo de $\mathrm{Hg}$ nos sedimentos, dando indícios de uma fonte alóctone desse metal no sistema.

Santos 1 apresentou um padrão de concentração de $\mathrm{Hg}$ diferente dos demais testemunhos. Observou-se nas primeiras porções da coluna sedimentar um grande aumento, embora não constante, na concentração de $\mathrm{Hg}$. Os teores nessa porção encontraram-se próximos aos valores de TEL-Nível 1, não os superando.

É notória a influência antrópica na região do ponto Santos 2. Observou-se na Figura 19 um crescimento acelerado na acumulação de $\mathrm{Hg}$ no sedimento a partir da profundidade de $100 \mathrm{~cm}$ (data estimada: 1920), sendo acentuado a partir da profundidade de $50 \mathrm{~cm}$ (data estimada: 1965). A partir da profundidade de $18 \mathrm{~cm}$ (data estimada:1999) as concentrações passaram a diminuir. Analisando a industrialização na baixada santista notamos a concordância dos dados com os eventos históricos. A partir da década de 1950 houve um grande desenvolvimento industrial na região, acelerado principalmente pela criação da Via Anchieta. A concentração de $\mathrm{Hg}$ assim seguiu aumentando até meados dos anos 2000 quando sofreu uma queda, possivelmente reflexo dos programas de controle ambiental liderados pela CETESB. As concentrações de $\mathrm{Hg}$ nos períodos de grande crescimento superaram os valores de PEL-Nível 2, indicando grande preocupação ambiental.

Santos 4, embora tenha apresentado baixos valores de $\mathrm{Hg}$ em porções majoritárias da coluna sedimentar, demonstrou altos crescimentos na porção mais superficial, acima da profundidade de $14 \mathrm{~cm}$. Próximos ao topo as concentrações superaram os valores de TELNível 1, podendo refletir a influência das atividades humanas nos sedimentos.

O testemunho Santos 8 apresentou um padrão semelhante àquele apresentado em Santos 2. Observou-se, a partir dos $50 \mathrm{~cm}$ de profundidade (data estimada: 1949) um aumento acentuado na concentração de Hg. Os valores superficiais superaram os valores de TEL-Nível 1, estando próximas aos valores de PEL-Nível 2. Assim como em Santos 2, o grande aumento na concentração pôde estar intimamente ligada ao crescimento na industrialização da região. 

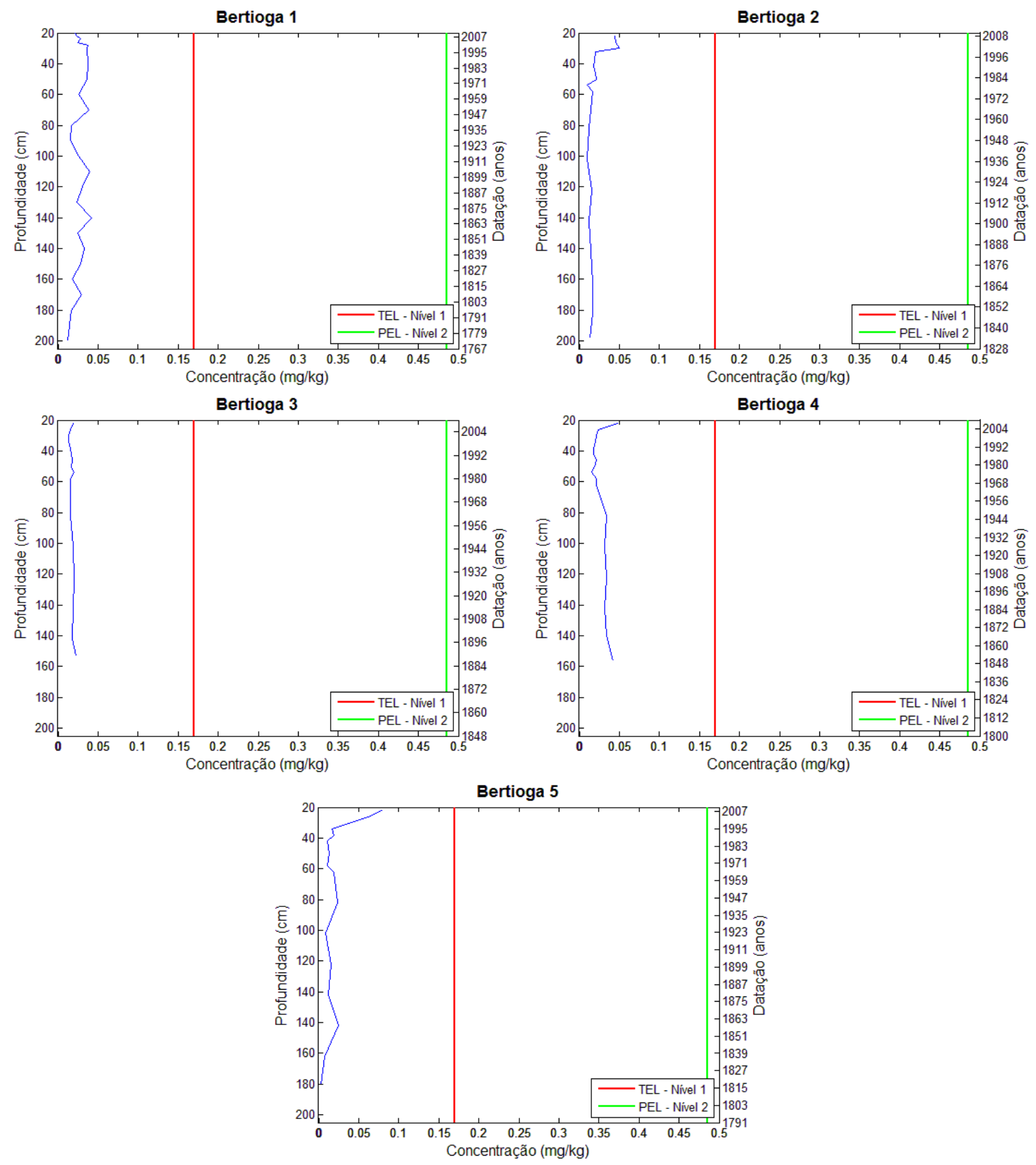

Figura 18. Valores de concentração de $\mathrm{Hg}(\mathrm{mg} / \mathrm{kg})$ para os testemunhos localizados no Canal de Bertioga. 

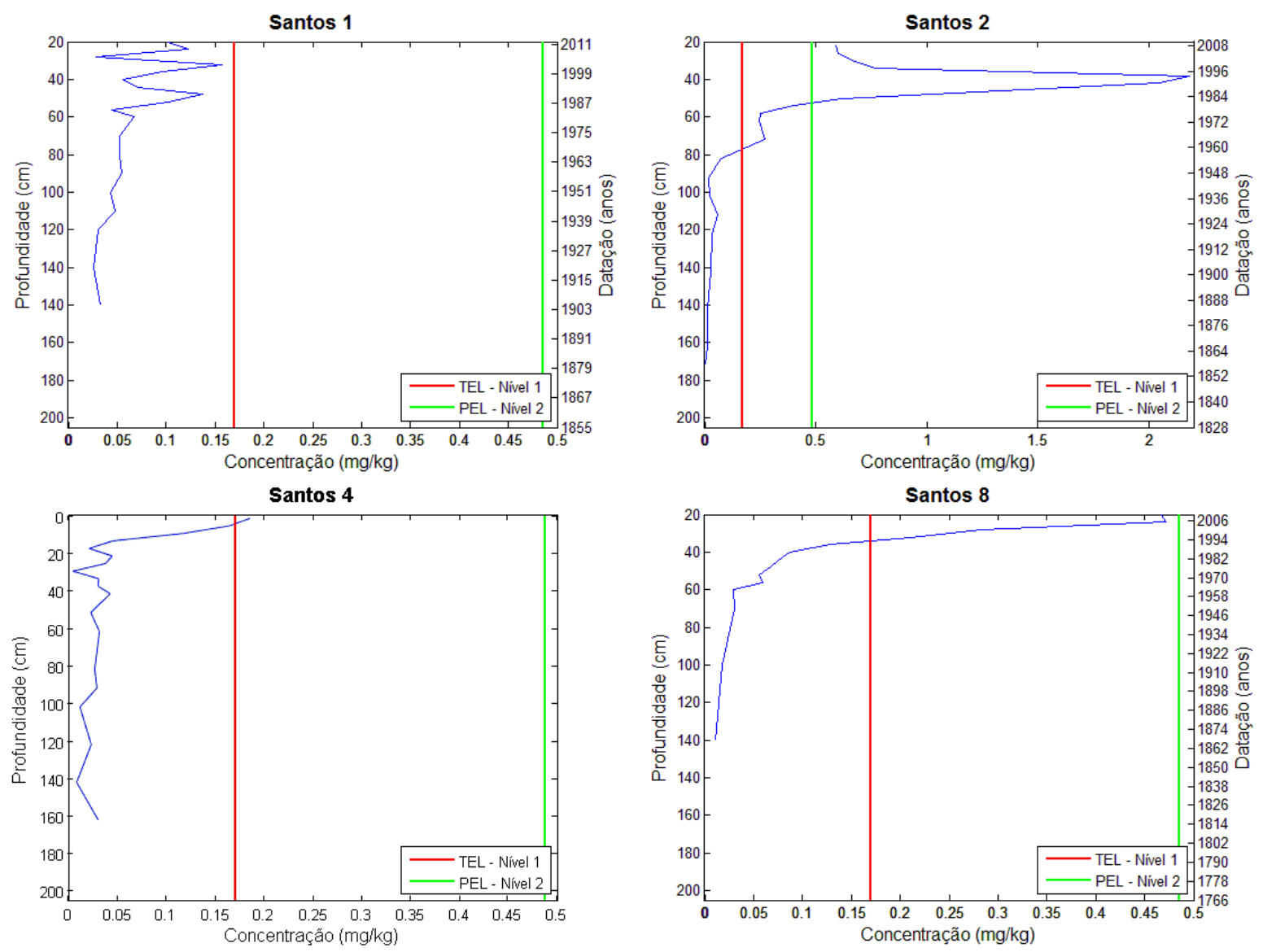

Figura 19. Valores de concentração de $\mathrm{Hg}(\mathrm{mg} / \mathrm{kg})$ para os testemunhos localizados em Santos.

\section{Níquel (Ni)}

A Figura 20 e Figura 21 apresentam os valores de Ni obtidos nos testemunhos localizados no Canal de Bertioga e Santos, respectivamente. O testemunho Bertioga 1 demonstrou valores homogêneos de $\mathrm{Ni}$ ao longo da coluna sedimentar, seus valores oscilaram em torno de $10 \mathrm{mg} / \mathrm{kg}$. Um leve acréscimo pôde ser notado nas porções superficiais do testemunho. Todo o testemunho expressou valores inferiores à TEL-Nivel 1.

Os valores de $\mathrm{Cu}$ obtidos para Bertioga 2 foram inferiores aos obtidos em Bertioga 1, observou-se pequenas variações ao longo do testemunho. O perfil sedimentar não apresentou indícios de contaminação, estando abaixo dos valores legais.

Bertioga 3 demonstrou teores homogêneos de $\mathrm{Cu}$ em toda a coluna sedimentar, sofrendo um pequena queda na porção superficial a partir dos $40 \mathrm{~cm}$ de profundidade (data estimada: 1976). Os valores médios variaram em torno de $12 \mathrm{mg} / \mathrm{kg}$.

Bertioga 4 apresentou pequenas oscilações ao longo da coluna sedimentar no que se diz respeito à concentração de Ni. De maneira geral, notou-se uma camada de baixas 
concentrações entre as profundidades de 88 e $108 \mathrm{~cm}$ (período estimado: 1901 -1921). Observou-se um novo decréscimo a partir da profundidade de $60 \mathrm{~cm}$ (data estimada: 1950) em direção ao topo.

Bertioga 5 apresentou concentrações de Ni mais elevadas do que as apresentadas nos demais testemunhos localizados no Canal de Bertioga. Os valores expressos, em quase toda coluna sedimentar encontraram-se variando próximos ao TEL-Nível 1 (18 mg/kg). Próximos à superfície, a partir da profundidade de $32 \mathrm{~cm}$ (data estimada: 1978), notou-se um decréscimo desses valores. Que puderam ser justificados pela queda nos teores de sedimentos finos (como observado na seção 5.1).

O testemunho Santos 1 expressou um decréscimo na concentração de Ni da base em direção ao topo. Esse mesmo padrão pôde ser observado no perfil correspondente ao teor de sedimentos finos na coluna sedimentar, indicando que a variação de $\mathrm{Ni}$ no testemunho possivelmente está relacionada com as variações de silte e argila.

Santos 2 apresentou valores de Ni homogêneos ao longo do testemunho. Notou-se que os valores oscilam em torno de $15 \mathrm{mg} / \mathrm{kg}$, não atingindo em nenhum ponto o valor de TEL-Nível 1. Já no testemunho Santos 4 evidenciou-se que, assim como Santos 1, seguiu o mesmo padrão daquele apresentado pelos teores finos, estando homogêneos ao longo da coluna. Os valores médios em Santos 4 oscilaram em torno de $8,7 \mathrm{mg} / \mathrm{kg}$.

Santos 8 foi o único testemunho a indicar um pequeno indicio de influência antrópica. Notou-se um aumento na concentração nas porções acima de $50 \mathrm{~cm}$ de profundidade (data estimada: 1954), chegando a superar os valores de TEL-Nível 1. Embora tenham indicado uma possível influência antrópica, os valores obtidos não demonstraram uma contaminação significativa. 

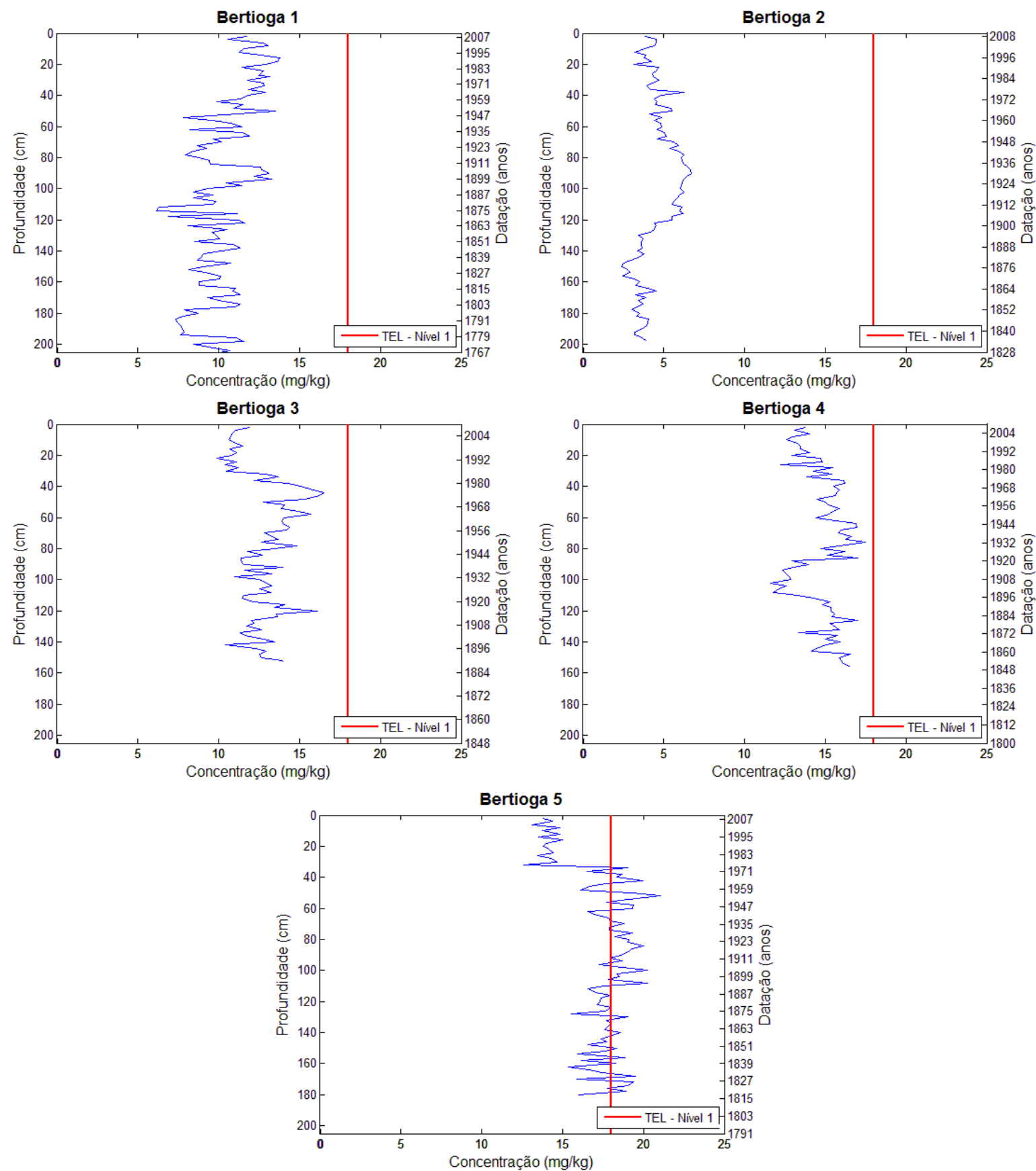

Figura 20. Valores de concentração de Ni (mg/kg) para os testemunhos localizados no Canal de Bertioga. 

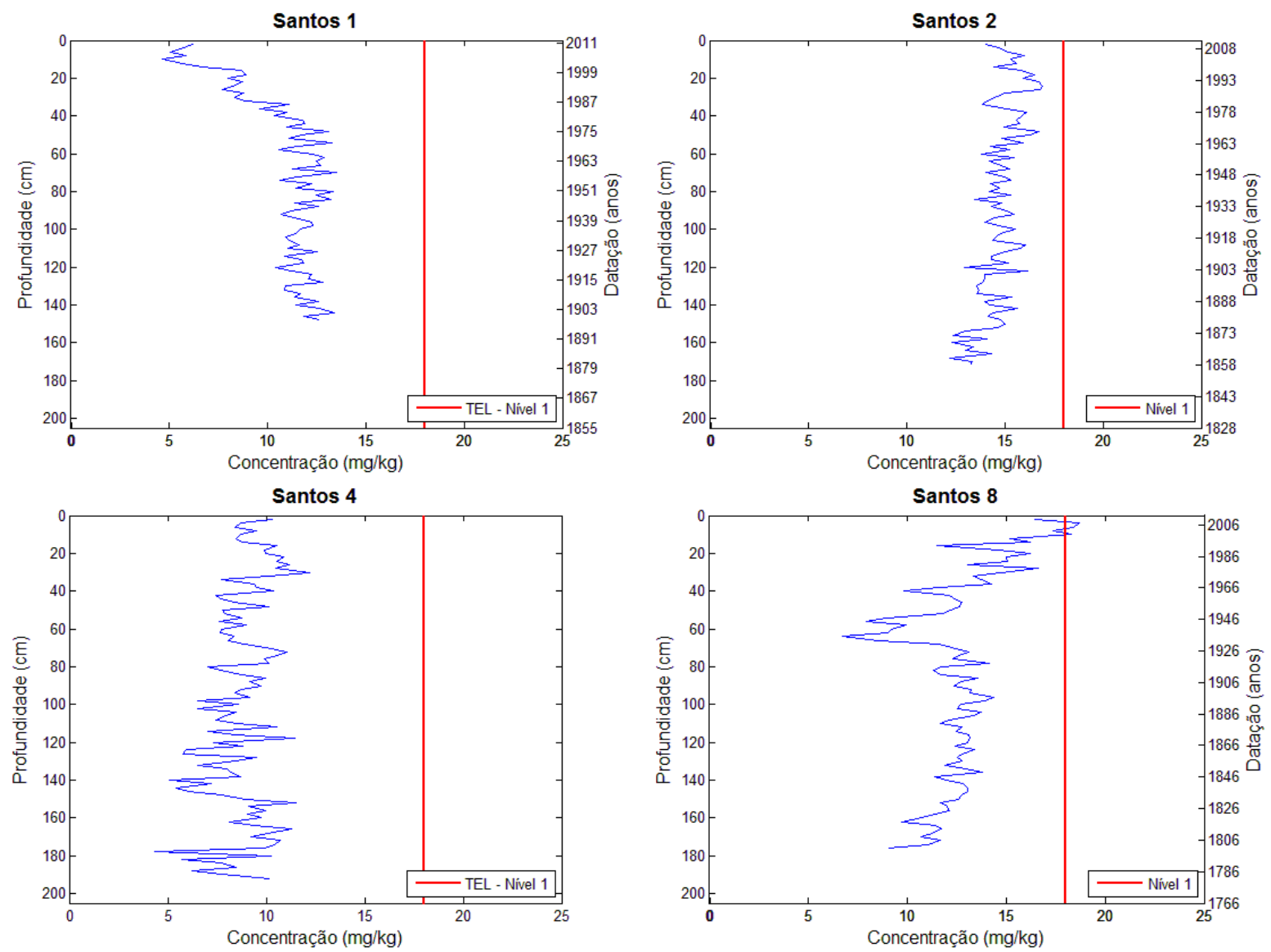

Figura 21. Valores de concentração de Ni $(\mathrm{mg} / \mathrm{kg})$ para os testemunhos localizados em Santos.

\section{Chumbo (Pb)}

Os testemunhos localizados no Canal de Bertioga, demonstrados na Figura 22 apresentaram valores homogêneos de $\mathrm{Pb}$ ao longo da coluna sedimentar. Os cinco testemunhos estudados demonstraram concentrações abaixo do limite de TEL-Nível 1, não indicando contaminações. O testemunho Bertioga 2 mostrou as menores concentrações, com valores médios em torno de 4,7 mg/kg. Os maiores valores foram encontrados em Bertioga 5, com valores médios de $16,3 \mathrm{mg} / \mathrm{kg}$, seguidos por Bertioga 4 , com valores oscilando em torno de 14,9 mg/kg e Bertioga 3 com 14,0 mg/kg. Bertioga 1 apresentou média de 10,0 mg/kg. 

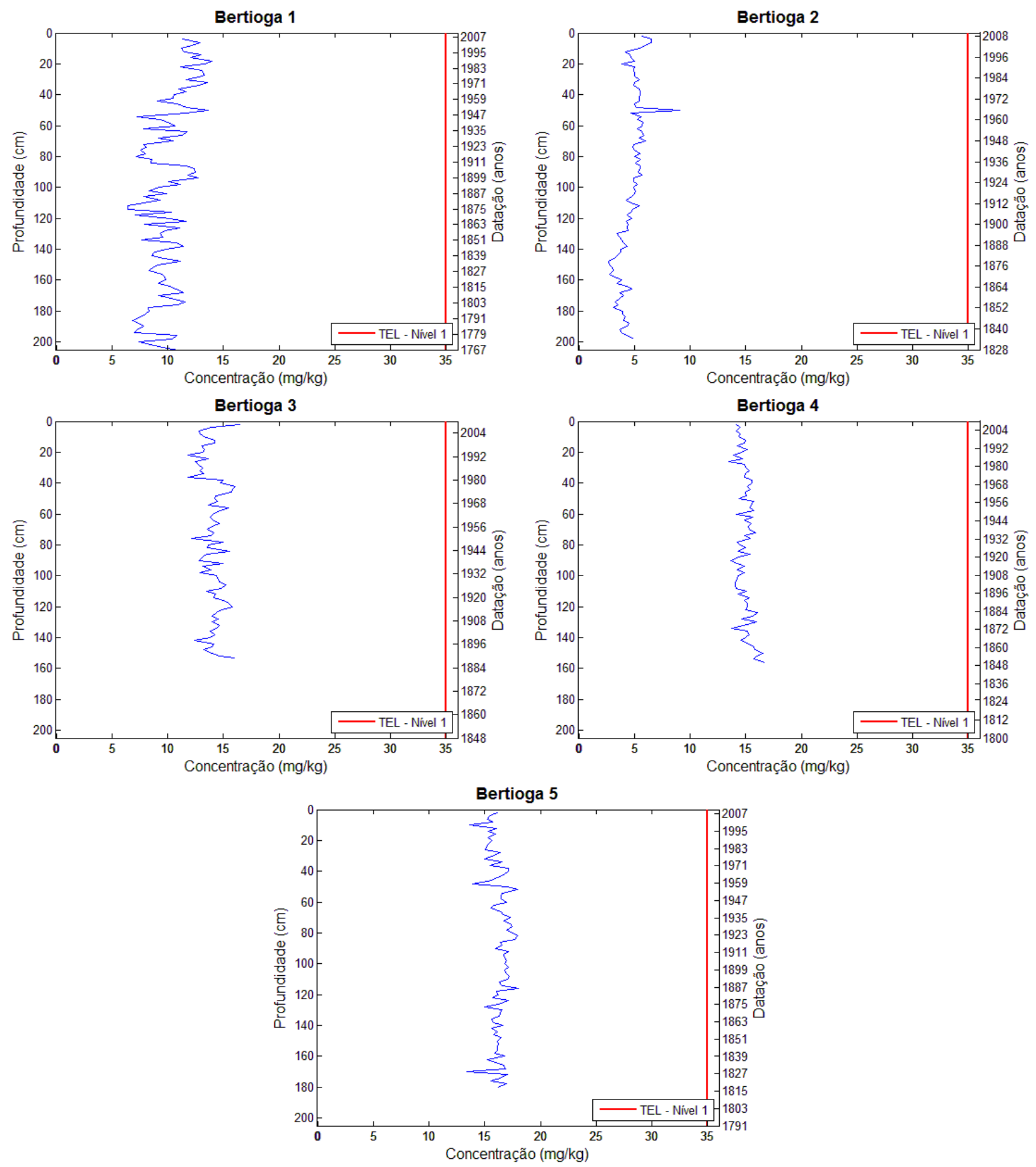

Figura 22. Valores de concentração de Pb ( $\mathrm{mg} / \mathrm{kg}$ ) para os testemunhos localizados no Canal de Bertioga.

Os testemunhos localizados em Santos, demonstrados na Figura 23, apresentaram pequenas variações ao longo da coluna sedimentar. Santos 1 apresentou, de maneira geral, valores homogêneos, com um pequeno decréscimo entre as profundidades de 10 e $36 \mathrm{~cm}$ (período estimado: 1986 - 2006), seguido por um pequeno aumento de $10 \mathrm{~cm}$ de profundidade em direção ao topo. Santos 2 apresentou um pequeno crescimento no teor de $\mathrm{Pb}$ em direção ao topo em toda a coluna sedimentar, sendo este mais abrupto a partir da 
profundidade de $60 \mathrm{~cm}$ (data estimada: 1958). Nos primeiros $22 \mathrm{~cm}$ de profundidade (data estimada: 1994), notou-se uma diminuição da concentração de $\mathrm{Pb}$. Santos 4 apresentou um padrão homogêneo ao longo da coluna sedimentar, se assemelhando aos padrões de silte e argila, indicando uma possível associação entre os dois parâmetros. Santos 8, assim como Santos 2 expressou um grande acréscimo nas concentrações de $\mathrm{Pb}$ a partir da profundidade de $58 \mathrm{~cm}$ (data estimada: 1949) com relação ao topo do testemunho. Embora os valores de concentração em Santos 8 não sejam característicos de regiões contaminadas, o grande aumento nos teores de $\mathrm{Pb}$ nos últimos 60 anos puderam indicar uma influência antrópica no meio.
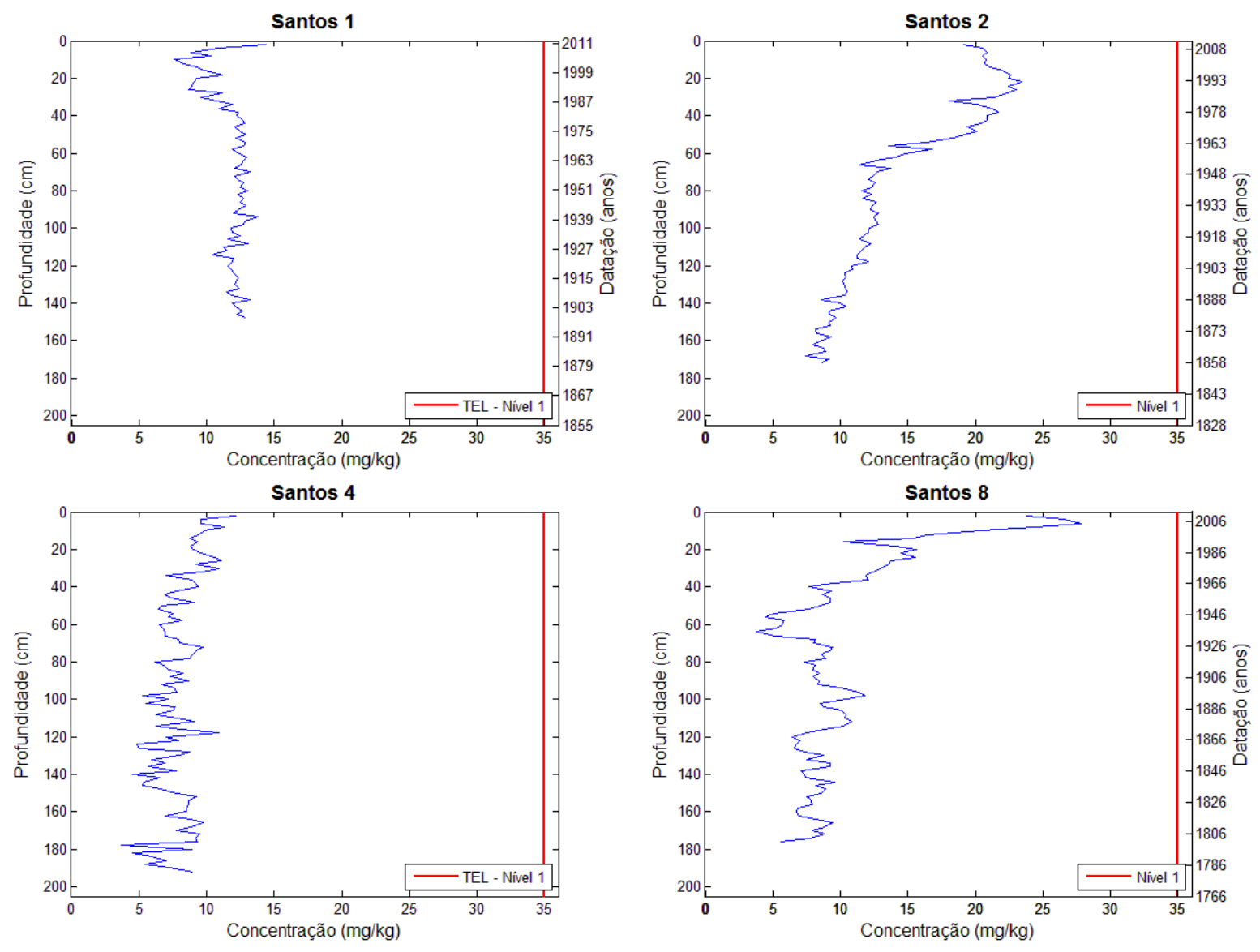

Figura 23. Valores de concentração de Pb (mg/kg) para os testemunhos localizados em Santos.

\section{$\operatorname{Zinco}(\mathbf{Z n})$}

Os testemunhos localizados no Canal de Bertioga, demonstrados na Figura 24, apresentaram concentrações de Zn homogêneas ao longo da coluna sedimentar. Os maiores valores foram observados em Bertioga 5, com valores médios em torno de 64,2 mg/kg. Em seguida observou-se Bertioga 4 com concentrações médias de 52,6 mg/kg. O testemunho 
Bertioga 3 apresentou valores de $\mathrm{Zn}$ em torno de 50,37 mg/kg. Já Bertioga 1 obteve concentrações médias próximas a 47,8 mg/kg. Os menores valores foram notados em Bertioga 2, com valores médios em torno de $22,6 \mathrm{mg} / \mathrm{kg}$. Todos os valores observados para os testemunho localizados no Canal de Bertioga estiveram muito abaixo dos valores orientadores de TEL-Nível 1, indicando possíveis níveis basais de Zn nesse sistema.
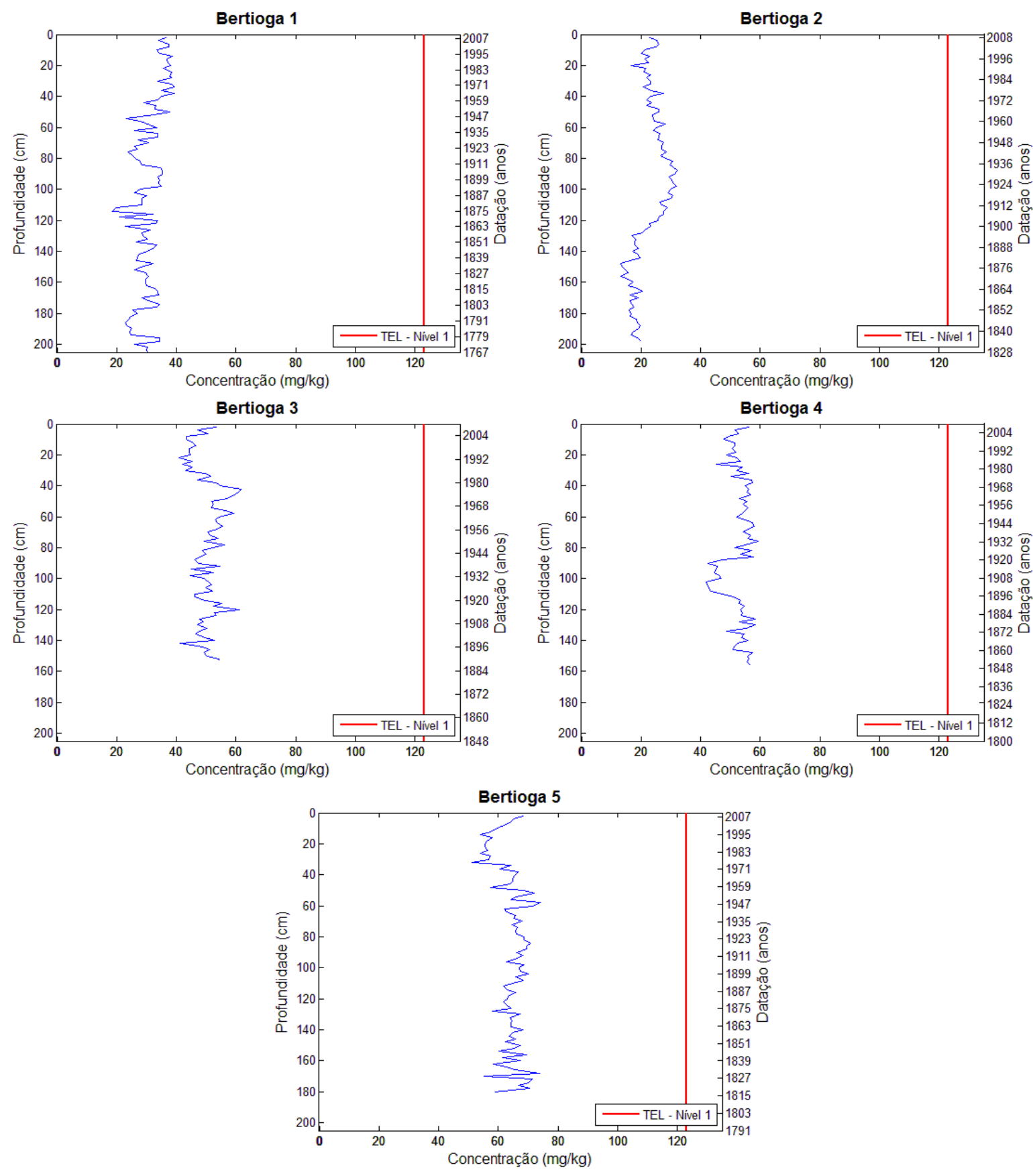

Figura 24.Valores de concentração de Zn (mg/kg) para os testemunhos localizados no Canal de Bertioga. 
Os testemunhos localizados em Santos são demonstrados na Figura 25. Santos 1 apresentou um perfil de $\mathrm{Zn}$ indicando uma diminuição de sua concentração na direção base topo. Essa característica se assemelhou ao padrão de sedimentos finos na amostra, podendo indicar uma associação entre a variação de silte e argila e a concentração de Zn no sedimento.

Santos 2 apresentou um padrão distinto dos demais apresentados. Houve um significativo aumento na concentração de $\mathrm{Zn}$ a partir da profundidade de $62 \mathrm{~cm}$ (data estimada: 1956) em direção ao topo do testemunho. As concentrações apresentadas nesse testemunho estão abaixo dos valores orientadores de TEL-Nível 1, não indicando uma contaminação de Zn nesse ponto. No entanto, o grande crescimento nas concentrações nos últimos 60 anos sugeriu uma influencia antópica na região.

O testemunho Santos 8 apresentou os valores mais críticos de $\mathrm{Zn}$ na coluna sedimentar. Observou-se um crescimento exponencial nos valores de concentração nos últimos 40 anos. Os valores apresentados para os últimos 10 anos superam os limites de TELNível 1, indicando concentrações que podem afetar a biota local.
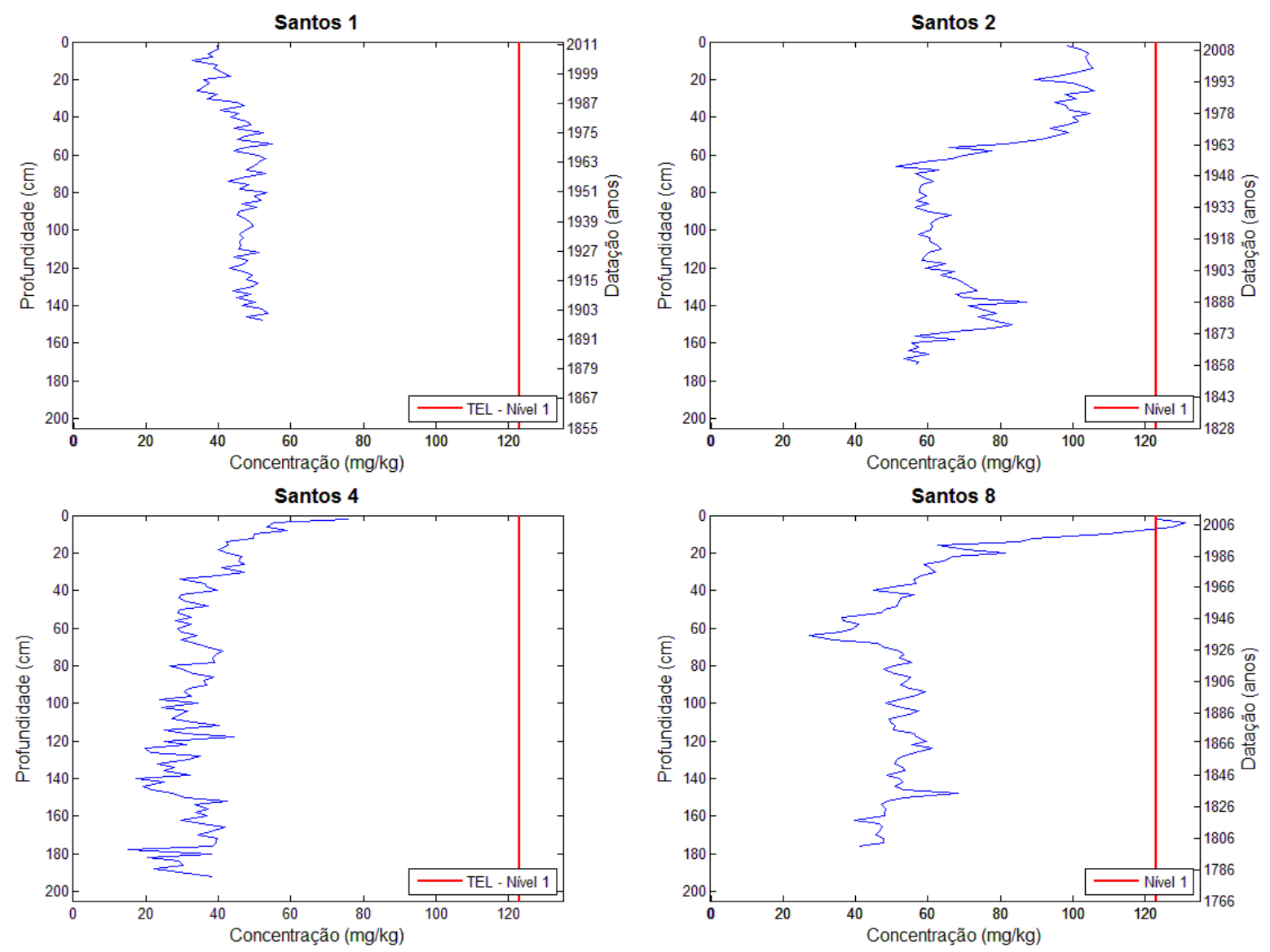

Figura 25. Valores de concentração de Zn $(\mathrm{mg} / \mathrm{kg})$ para os testemunhos localizados em Santos. 


\subsubsection{Determinação dos valores de background}

A obtenção dos valores naturais de metais nos sedimentos é uma importante informação para estabelecer valores guias, ou valores orientadores. Muitas agências ambientais pelo mundo têm utilizado esses valores para definir níveis do grau de contaminação e toxicidade dos sedimentos para fins de monitoramento, avaliação da qualidade, e em muitos casos, para fins de dragagem e consequentemente os critérios de deposição desse material ou outra finalidade regulatória (Quináglia, 2006).

O presente trabalho buscou estimar os valores de background dos metais na região de Santos e Canal de Bertioga. Esses níveis são de suma importância para a análise da contaminação por metais e semimetais nesses locais. Os níveis naturais de metais permitem a análise da influência antrópica na região em questão.

Para se estimar os níveis basais dos testemunhos realizou-se a digestão total das amostras dos últimos $5 \mathrm{~cm}$ de cada coluna sedimentar. Essa camada correspondeu, nas colunas sedimentares estudadas, a períodos anteriores a industrialização da região. A escolha da utilização dos valores obtidos a partir da digestão total das amostras deu-se pelo fato desta refletir teores de metais oriundos tanto da estrutura cristalina do sedimento quando da porção mais facilmente disponível, não tomando como referência para nível basal apenas as frações mais facilmente disponíveis para o ambiente.

As Tabela 7 e Tabela 8 apresentam os valores de concentração e seus respectivos valores estatísticos obtidos para os elementos estudados a partir da digestão total dos sedimentos. Podemos observar que os valores médios nos nove testemunhos estudados foram bastante próximos. As pequenas variações apresentadas puderam ser justificadas pelas diferenças granulométricas. 
Tabela 7. Valores de concentração (em $\mathrm{mg} / \mathrm{kg}$ ) para amostras da base dos testemunhos, localizados no Canal de Bertioga, analisados a partir da digestão total do sedimento.

\begin{tabular}{|c|c|c|c|c|c|c|c|c|c|c|c|c|}
\hline & Profund. & Al & As & $\mathrm{Cr}$ & $\mathbf{C u}$ & $\mathrm{Fe}$ & Mn & $\mathrm{Ni}$ & $\mathbf{P b}$ & Sc & V & $\mathbf{Z n}$ \\
\hline \multirow{9}{*}{ B1 } & 198 & 50786,4 & 11,22 & 45,14 & 10,81 & 22042,9 & 407,2 & 16,83 & 16,84 & 8,50 & 58,72 & 65,22 \\
\hline & 200 & 39040,1 & 7,77 & 29,92 & 6,72 & 16352,7 & 303,2 & 11,05 & 13,57 & 5,39 & 39,04 & 45,67 \\
\hline & 202 & 43698,3 & 9,95 & 38,33 & 8,37 & 19747,4 & 365,3 & 14,28 & 15,68 & 6,78 & 51,87 & 56,41 \\
\hline & 204 & 46151,9 & 9,97 & 42,07 & 9,12 & 20938,8 & 394,4 & 16,18 & 15,71 & 7,44 & 54,60 & 60,72 \\
\hline & 206 & 41298,1 & 8,76 & 38,38 & 9,96 & 18410,2 & 335,1 & 15,56 & 18,44 & 6,28 & 48,45 & 108,41 \\
\hline & Máximo & 50786,4 & 11,22 & 45,14 & 10,81 & 22042,9 & 407,2 & 16,83 & 18,44 & 8,50 & 58,72 & 108,41 \\
\hline & Mínimo & 39040,1 & 7,77 & 29,92 & 6,72 & 16352,7 & 303,2 & 11,05 & 13,57 & 5,39 & 39,04 & 45,67 \\
\hline & Média & 43698,3 & 9,95 & 38,38 & 9,12 & 19747,4 & 365,3 & 15,56 & 15,71 & 6,78 & 51,87 & 60,72 \\
\hline & Desv. Pad & 4541,1 & 1,31 & 5,71 & 1,57 & 2218,7 & 42,7 & 2,29 & 1,78 & 1,18 & 7,45 & 24,11 \\
\hline
\end{tabular}

\begin{tabular}{|c|c|c|c|c|c|c|c|c|c|c|c|c|}
\hline \multirow{9}{*}{ B2 } & 190 & 28525,5 & 9,13 & 21,42 & 4,56 & 12269,8 & 159,2 & 7,71 & 11,75 & 3,65 & 26,71 & 30,58 \\
\hline & 192 & 26231,6 & 4,77 & 16,52 & 4,19 & 9760,1 & 127,5 & 6,04 & 9,92 & 2,90 & 21,03 & 23,99 \\
\hline & 194 & 27833,7 & 6,21 & 20,38 & 4,23 & 11274,8 & 159,8 & 6,93 & 10,81 & 3,45 & 24,73 & 28,54 \\
\hline & 196 & 26750,0 & 8,09 & 17,23 & 3,92 & 10189,3 & 149,4 & 6,17 & 9,07 & 3,31 & 21,49 & 27,63 \\
\hline & 198 & 29146,5 & 5,92 & 20,46 & 6,98 & 11632,0 & 150,0 & 7,32 & 12,86 & 3,59 & 25,04 & 33,92 \\
\hline & Máximo & 29146,5 & 9,13 & 21,42 & 6,98 & 12269,8 & 159,8 & 7,71 & 12,86 & 3,65 & 26,71 & 33,92 \\
\hline & Mínimo & 26231,6 & 4,77 & 16,52 & 3,92 & 9760,1 & 127,5 & 6,04 & 9,07 & 2,90 & 21,03 & 23,99 \\
\hline & Média & 27833,7 & 6,21 & 20,38 & 4,23 & 11274,8 & 150,0 & 6,93 & 10,81 & 3,45 & 24,73 & 28,54 \\
\hline & Desv. Pad & 1209,4 & 1,75 & 2,18 & 1,25 & 1034,3 & 13,1 & 0,72 & 1,49 & 0,30 & 2,44 & 3,67 \\
\hline
\end{tabular}

\begin{tabular}{|lccc|ccccccccc}
$\mathbf{1 4 6}$ & 62438,6 & 14,41 & 60,38 & 11,33 & 24076,8 & 686,3 & 21,11 & 18,71 & 10,90 & 78,56 & 67,11 \\
$\mathbf{1 4 8}$ & 79102,1 & 25,16 & 100,05 & 19,74 & 32972,0 & 1146,9 & 33,94 & 30,81 & 14,09 & 134,80 & 117,33 \\
$\mathbf{1 5 3}$ & 60621,8 & 16,34 & 66,66 & 14,34 & 25055,8 & 839,5 & 23,08 & 21,89 & 10,74 & 88,52 & 78,22 \\
$\mathbf{1 5 3}$ & $\mathbf{1 5 2}$ & 55067,4 & 15,08 & 59,43 & 10,99 & 23610,9 & 791,5 & 20,70 & 19,11 & 9,49 & 78,42 & 65,87 \\
& $\mathbf{1 5 4}$ & 61074,3 & 16,80 & 60,62 & 11,04 & 24702,0 & 769,6 & 21,25 & 18,70 & 10,33 & 78,64 & 67,95 \\
\hline & Máximo & 79102,1 & 25,16 & 100,05 & 19,74 & 32972,0 & 1146,9 & 33,94 & 30,81 & 14,09 & 134,80 & 117,33 \\
Mínimo & 55067,4 & 14,41 & 59,43 & 10,99 & 23610,9 & 686,3 & 20,70 & 18,70 & 9,49 & 78,42 & 65,87 \\
Média & 61074,3 & 16,34 & 60,62 & 11,33 & 24702,0 & 791,5 & 21,25 & 19,11 & 10,74 & 78,64 & 67,95 \\
Desv. Pad & 9078,8 & 4,36 & 17,36 & 3,76 & 3890,9 & 176,7 & 5,62 & 5,19 & 1,75 & 24,43 & 21,83
\end{tabular}

\begin{tabular}{|lccc|ccccccccc}
$\mathbf{1 4 8}$ & 57779,3 & 15,73 & 63,46 & 11,55 & 24527,4 & 719,0 & 23,04 & 20,24 & 9,70 & 83,36 & 72,16 \\
$\mathbf{1 5 0}$ & 56080,0 & 16,77 & 64,46 & 12,53 & 24760,0 & 746,3 & 24,06 & 20,93 & 8,89 & 87,72 & 77,84 \\
$\mathbf{1 5 2}$ & 68494,4 & 14,50 & 69,03 & 12,20 & 26437,9 & 729,0 & 24,65 & 20,81 & 12,40 & 89,17 & 76,83 \\
$\mathbf{B 4}$ & $\mathbf{1 5 4}$ & 54778,7 & 13,93 & 61,13 & 11,51 & 24002,4 & 878,1 & 23,44 & 21,04 & 8,94 & 82,23 & 75,28 \\
& $\mathbf{1 5 6}$ & 65692,4 & 13,83 & 64,15 & 11,57 & 25038,5 & 872,8 & 22,84 & 21,80 & 11,61 & 81,97 & 83,32 \\
& Máximo & 68494,4 & 16,77 & 69,03 & 12,53 & 26437,9 & 878,1 & 24,65 & 21,80 & 12,40 & 89,17 & 83,32 \\
Mínimo & 54778,7 & 13,83 & 61,13 & 11,51 & 24002,4 & 719,0 & 22,84 & 20,24 & 8,89 & 81,97 & 72,16 \\
Média & 57779,3 & 14,50 & 64,15 & 11,57 & 24760,0 & 746,3 & 23,44 & 20,93 & 9,70 & 83,36 & 76,83 \\
& Desv. Pad & 6134,4 & 1,27 & 2,88 & 0,46 & 913,0 & 79,5 & 0,75 & 0,56 & 1,61 & 3,33 & 4,09
\end{tabular}

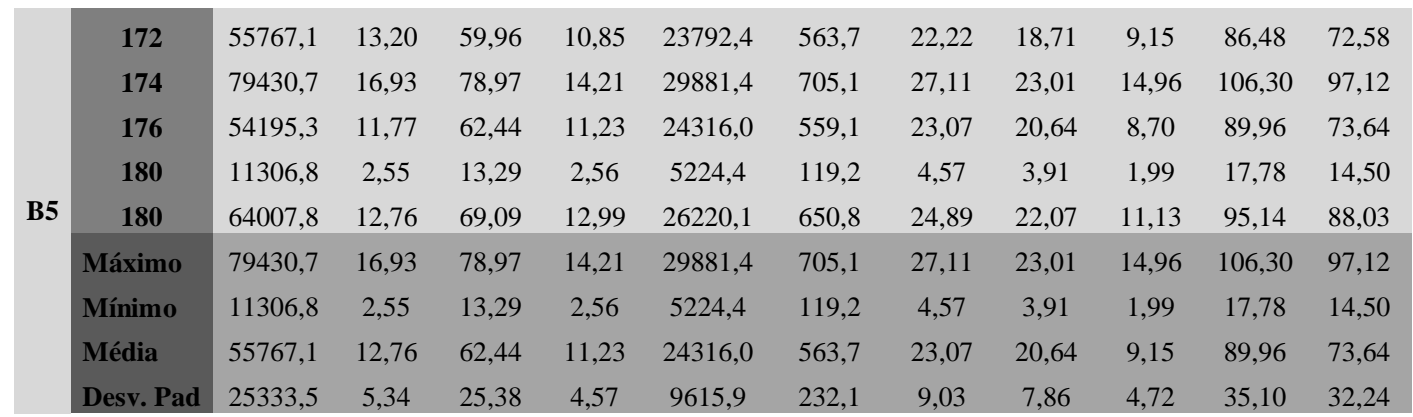


Tabela 8. Valores de concentração (em $\mathrm{mg} / \mathrm{kg}$ ) para amostras da base dos testemunhos, localizados em Santos, analisados a partir da digestão total do sedimento.

\begin{tabular}{|c|c|c|c|c|c|c|c|c|c|c|c|c|}
\hline & Profund. & Al & As & $\mathrm{Cr}$ & $\mathrm{Cu}$ & Fe & Mn & $\mathbf{N i}$ & $\mathbf{P b}$ & Sc & V & Zn \\
\hline \multirow{9}{*}{ S1 } & 142 & 22838,1 & 10,76 & 62,33 & 13,73 & 17593,1 & 359,8 & 21,01 & 17,55 & 5,21 & 81,63 & 66,35 \\
\hline & 144 & 36690,5 & 10,79 & 52,33 & 17,84 & 16701,1 & 341,1 & 20,12 & 16,95 & 9,86 & 74,23 & 84,09 \\
\hline & 146 & 28637,3 & 11,94 & 58,54 & 14,94 & 17188,3 & 351,0 & 21,38 & 18,50 & 7,54 & 84,01 & 73,42 \\
\hline & 148 & 25890,2 & 10,82 & 59,59 & 14,79 & 17216,0 & 360,2 & 21,89 & 18,07 & 8,11 & 87,23 & 69,64 \\
\hline & 150 & 23514,4 & 11,89 & 58,39 & 14,74 & 16712,8 & 359,6 & 21,49 & 18,18 & 6,42 & 86,69 & 69,40 \\
\hline & Máximo & 36690,5 & 11,94 & 62,33 & 17,84 & 17593,1 & 360,2 & 21,89 & 18,50 & 9,86 & 87,23 & 84,09 \\
\hline & Mínimo & 22838,1 & 10,76 & 52,33 & 13,73 & 16701,1 & 341,1 & 20,12 & 16,95 & 5,21 & 74,23 & 66,35 \\
\hline & Média & 27514,1 & 11,24 & 58,23 & 15,21 & 17082,3 & 354,3 & 21,18 & 17,85 & 7,43 & 82,76 & 72,58 \\
\hline & Desv. Pad & 5611,8 & 0,62 & 3,66 & 1,55 & 378,1 & 8,4 & 0,67 & 0,61 & 1,75 & 5,27 & 6,91 \\
\hline
\end{tabular}

\begin{tabular}{|c|c|c|c|c|c|c|c|c|c|c|c|}
\hline 166 & 17428,5 & 15,09 & 54,77 & 15,20 & 16252,7 & 198,5 & 20,10 & 19,96 & 4,09 & 66,72 & 70,17 \\
\hline 168 & 23322,9 & 17,65 & 58,04 & 15,27 & 18220,2 & 236,2 & 20,99 & 20,00 & 5,20 & 69,80 & 80,60 \\
\hline 170 & 20239,8 & 18,54 & 58,22 & 15,25 & 18225,6 & 226,1 & 21,35 & 19,82 & 4,19 & 70,23 & 75,04 \\
\hline 172 & 24808,2 & 14,71 & 56,37 & 14,35 & 16944,4 & 213,0 & 20,67 & 18,04 & 6,26 & 66,94 & 72,93 \\
\hline 174 & 34122,4 & 15,59 & 61,49 & 16,01 & 18196,5 & 226,1 & 22,60 & 19,26 & 9,31 & 72,12 & 80,70 \\
\hline Máximo & 34122,4 & 18,54 & 61,49 & 16,01 & 18225,6 & 236,2 & 22,60 & 20,00 & 9,31 & 72,12 & 80,70 \\
\hline Mínimo & 17428,5 & 14,71 & 54,77 & 14,35 & 16252,7 & 198,5 & 20,10 & 18,04 & 4,09 & 66,72 & 70,17 \\
\hline Média & 23984,4 & 16,32 & 57,78 & 15,22 & 17567,9 & 220,0 & 21,14 & 19,42 & 5,81 & 69,16 & 75,89 \\
\hline Desv. Pad & 6342,3 & 1,68 & 2,51 & 0,59 & 918,1 & 14,6 & 0,94 & 0,82 & 2,14 & 2,30 & 4,68 \\
\hline
\end{tabular}

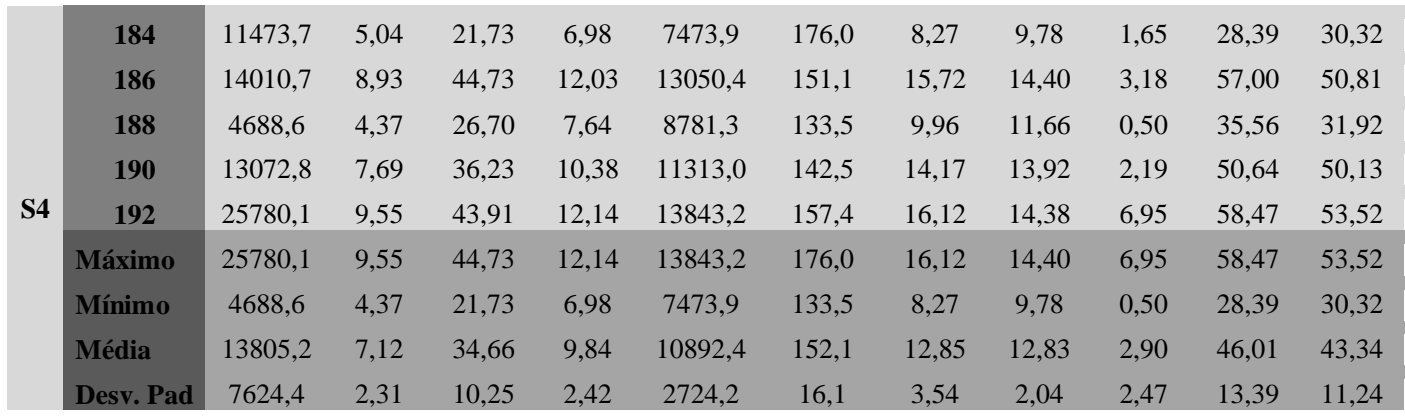

\begin{tabular}{|c|c|c|c|c|c|c|c|c|c|c|c|}
\hline 168 & 25461,9 & 14,19 & 44,46 & 15,51 & 17336,3 & 139,2 & 17,87 & 17,85 & 6,12 & 61,53 & 71,23 \\
\hline 170 & 22131,5 & 14,29 & 51,24 & 15,83 & 18695,7 & 157,5 & 20,05 & 21,69 & 4,65 & 69,89 & 76,80 \\
\hline 172 & 20072,5 & 12,96 & 53,76 & 17,27 & 18547,7 & 194,2 & 20,73 & 20,99 & 4,09 & 73,40 & 72,83 \\
\hline 174 & 24378,2 & 14,24 & 51,38 & 16,04 & 17981,5 & 177,7 & 19,69 & 20,49 & 5,58 & 70,38 & 72,53 \\
\hline 176 & 15756,6 & 11,91 & 40,47 & 12,93 & 14913,3 & 184,9 & 16,61 & 19,59 & 3,36 & 60,51 & 71,37 \\
\hline Máximo & 25461,9 & 14,29 & 53,76 & 17,27 & 18695,7 & 194,2 & 20,73 & 21,69 & 6,12 & 73,40 & 76,80 \\
\hline Mínimo & 15756,6 & 11,91 & 40,47 & 12,93 & 14913,3 & 139,2 & 16,61 & 17,85 & 3,36 & 60,51 & 71,23 \\
\hline Média & 21560,1 & 13,52 & 48,26 & 15,52 & 17494,9 & 170,7 & 18,99 & 20,12 & 4,76 & 67,14 & 72,95 \\
\hline Desv. Pad & 3853,1 & 1,06 & 5,57 & 1,59 & 1539,2 & 22,2 & 1,70 & 1,48 & 1,11 & 5,76 & 2,26 \\
\hline
\end{tabular}

\subsection{Estudos anteriores no Brasil}

De forma a avaliar as concentrações de metais encontradas no presente trabalho, é apresentado na Tabela 9 um comparativo entre a área de estudo e diferentes regiões do Brasil. 
Para uma melhor discussão, a abordagem foi dividida entre Canal de Bertioga e Estuário de Santos, uma vez que suas concentrações são bastante distintas.

Com relação ao Canal de Bertioga, observou-se que as concentrações apresentadas são semelhantes àquelas encontradas por Quináglia (2006), estando As, Cr, Cu, Hg, Ni e Zn na mesma ordem de grandeza. Distingue-se apenas os valores de $\mathrm{Pb}$, que apresentaram concentrações superiores às encontradas por este autor. Notou-se que, de maneira geral, os valores obtidos no Canal de Bertioga foram inferiores aos encontrados nas outras regiões do Brasil apresentadas, consideradas pela literatura como regiões impactadas.

Para os valores constatados no Estuário de Santos, observou-se uma grande semelhança com os teores apresentados por Torres (2007). Todos os elementos analisados estiveram na mesma ordem de grandeza deste último. Com relação às demais regiões estudadas, notou-se que o Estuário Santista apresentou concentrações de metais superiores às encontradas na Baía de Todos os Santos (BA) por Celino et al. (2008) e para alguns elementos, superiores aos encontrados no Estuário de Paranaguá (PR) por Choueri et al. (2009). No entanto, são inferiores aos encontrados na Baía de Guanabara (RJ) por Neto et al. (2006). 
Tabela 9. Valores máximos e mínimos de As e metais $(\mathrm{mg} / \mathrm{kg})$ em diferentes estudos e regiões do Brasil.

\begin{tabular}{|c|c|c|c|c|c|c|c|c|c|c|}
\hline Região estudada & As & $\mathrm{Cr}$ & $\mathbf{C u}$ & Hg & $\mathbf{N i}$ & $\mathbf{P b}$ & $\mathbf{Z n}$ & $\begin{array}{c}\text { Tipo de } \\
\text { amostragem }\end{array}$ & Método de análise & Referência \\
\hline & Min. Máx. & Min. Máx. & Min. Máx. & Min. Máx. & Min. Máx. & Min. Máx. & Min. Máx. & & & \\
\hline Baía de Todos os Santos - BA & - & $8,0-22,0$ & $16,7-25,9$ & - & $7,0-19,0$ & $8,0-22,0$ & $28,0-48,0$ & Superficial & Digestão parcial & Celino et al. (2008) \\
\hline Baía de Guanabara - RJ & - & $2,0-413,6$ & $2,0-88,4$ & - & $1,0-35,1$ & $2,0-193,4$ & $5,0-755,1$ & Superficial & Digestão total & Neto et al. (2006) \\
\hline Paranaguá - PR & $3,4-8,3$ & $14,5-58,0$ & $<0,04-16,2$ & $0,01-0,09$ & $6,6-21,9$ & $<0,30-29,7$ & $26,9-80,5$ & Superficial & Digestão parcial & Choueri et al. (2009) \\
\hline Canal de Bertioga- SP & $8,7-10,9$ & $26,1-29,5$ & $9,2-12,9$ & $<0,02$ & $10,1-12,3$ & $<0,26$ & $57,4-70,2$ & Testemunho & Digestão parcial & Quináguia (2006) \\
\hline Estuário de Santos - SP & $2,3-15,1$ & $8,6-41,9$ & $<1,0-21,1$ & $0,08-1,10$ & $<2,5-15,8$ & $<5,0-61,4$ & $16,8-135,9$ & Superficial & Digestão parcial & Torres (2007) \\
\hline Canal de Bertioga- SP & $4,3-23,6$ & $5,7-55,9$ & $1,4-26,7$ & $<0,02-0,08$ & $2,4-24,4$ & $2,7-27,8$ & $13,1-74,3$ & Testemunho & Digestão parcial & Presente trabalho \\
\hline Estuário de Santos - SP & $0,8-18,8$ & $10,8-41,1$ & $1,6-24,5$ & $<0,02-2,18$ & $1,5-18,7$ & $3,7-27,8$ & $15,2-131,2$ & Testemunho & Digestão parcial & Presente trabalho \\
\hline
\end{tabular}




\section{Discussão: reconstrução histórica a partir de testemunhos}

\subsection{Canal de Bertioga}

Os testemunhos localizados no Canal de Bertioga demonstraram características de um ambiente com baixa contaminação. Poucos elementos demonstraram valores que, segundo a legislação ambiental, representariam uma situação de alto risco ambiental.

Para a reconstrução da contaminação na região ao longo dos anos, será discutida a contribuição de cada elemento contaminante no sistema, e a situação de risco ambiental do sedimento como um todo. Levando em consideração os metais estudados e seus respectivos pesos tóxicos.

\subsubsection{Arsênio e metais contaminantes no Canal de Bertioga}

Sabendo-se que a concentração de metais nos sedimentos pode ser influenciada por fatores petrogenéticos, tais como mudanças na granulometria e composição mineral (UNEP, 1995), algumas normalizações foram realizadas a fim de verificar o real aumento no aporte antrópico nos elementos estudados. $\mathrm{O}$ fator de enriquecimento é uma normalização bastante utilizada para a análise de contaminação do sedimento, podendo avaliar separadamente cada elemento desejado, permitindo ainda corrigir as flutuações naturais a partir de um elemento conservativo.

O estudo do fator de enriquecimento permitiu avaliar aumentos na acumulação de alguns elementos nos últimos anos deposicionais. Destacou-se nesse ambiente o semimetal As. Os valores apresentados indicam, majoritariamente, ausência de contaminação. Em poucos pontos da porção mais superficial dos testemunhos Bertioga 2, Bertioga 3 e Bertioga 5 notou-se sedimentos caracterizados por contaminação significativa de As.

Embora não tenham apresentado valores de fator de enriquecimento característicos de regiões contaminadas por As, os testemunhos localizados no Canal de Bertioga refletiram a influência antrópica no ecossistema local. Notou-se na Figura 26, um significativo enriquecimento de As a partir da década de 1950, possível reflexo da influência industrial na região. Observou-se crescimentos efetivos nos valores de FE para As a partir da década de 
1970 nos testemunhos Bertioga 2, Bertioga 3 e Bertioga 5. Esse enriquecimento pôde indicar uma possível influência da modernização do Porto de Santos.
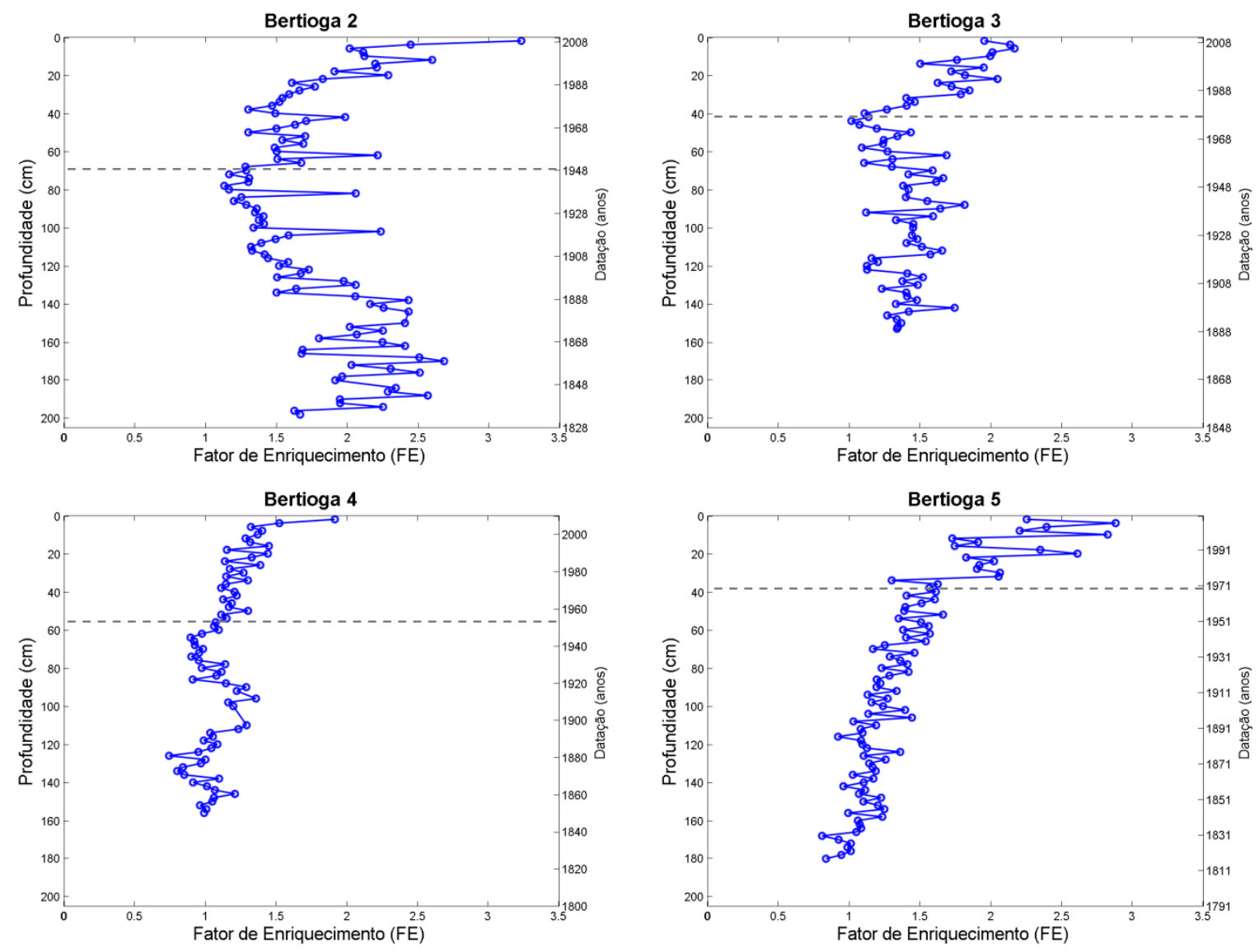

Figura 26. Perfis de fator de enriquecimento para As nos testemunhos Bertioga 2, 3, 4 e 5.

Os metais $\mathrm{Cu}, \mathrm{Pb}$ e $\mathrm{Zn}$ são elementos bastante utilizados em atividades industriais. A Figura 27, Figura 28 e Figura 29 apresentam os perfis de FE para alguns dos testemunhos estudados. Os comportamentos observados nos testemunhos estudados no Canal de Bertioga refletiram a possível influência antrópica nesse ambiente. Os valores de FE indicaram um significativo enriquecimento desses elementos nos testemunhos Bertioga 2, Bertioga 3 e Bertioga 5 que possivelmente foram oriundos de fontes não naturais. De maneira geral, o início do enriquecimento (marcado pela linha pontilhada), se deu nas décadas de 70 e 80, com exceção de $\mathrm{Pb}$, que em Bertioga 2 teve início na década de 50. 

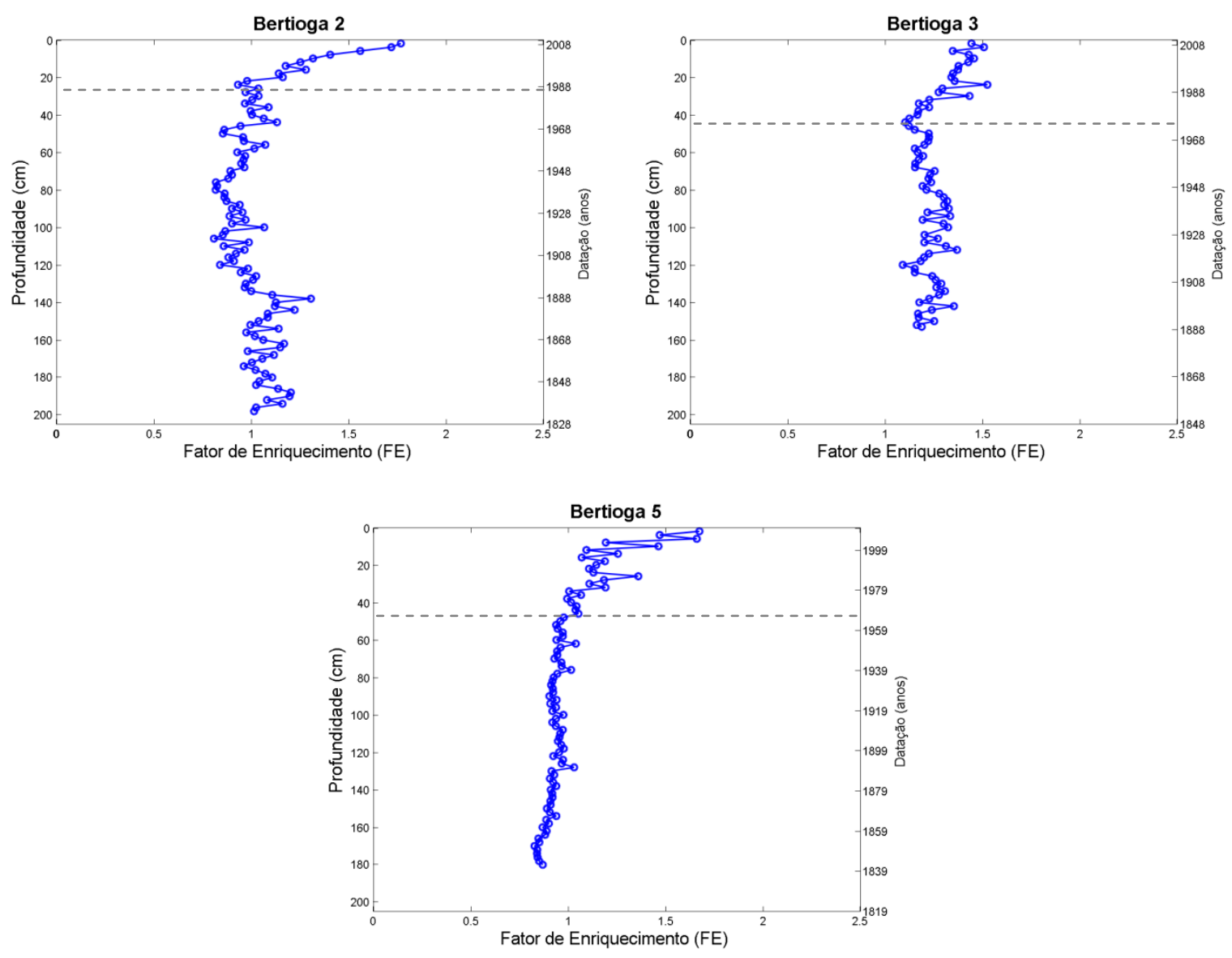

Figura 27. Perfis de fator de enriquecimento para Cu nos testemunhos Bertioga 2, 3 e 5.

$\mathrm{O}$ elemento $\mathrm{Cu}$, demonstrado na Figura 27, apresentou um aumento significativo no fator de enriquecimento a partir da década de 1970. Esse comportamento pôde ser reflexo do grande aumento das atividades industriais na Baixada Santista. A tabela presente no Anexo 3 destaca as principais atividades históricas da região durante o período estudado. Nela, observou-se que a partir da década de 1970 houve um grande aumento populacional e industrial na região, que acarretaram em grandes mudanças ambientais.

Para o metal $\mathrm{Pb}$, observou-se na Figura 28 aumentos abruptos nos valores de fator de enriquecimento ao longo da coluna sedimentar. Embora tenham iniciado e períodos distintos, Bertioga 2 a partir da década de 1950, Bertioga 3 e Bertioga 5 na década de 1970, notou-se que possivelmente são reflexos de mudanças históricas que afetaram diretamente o meio ambiente. 

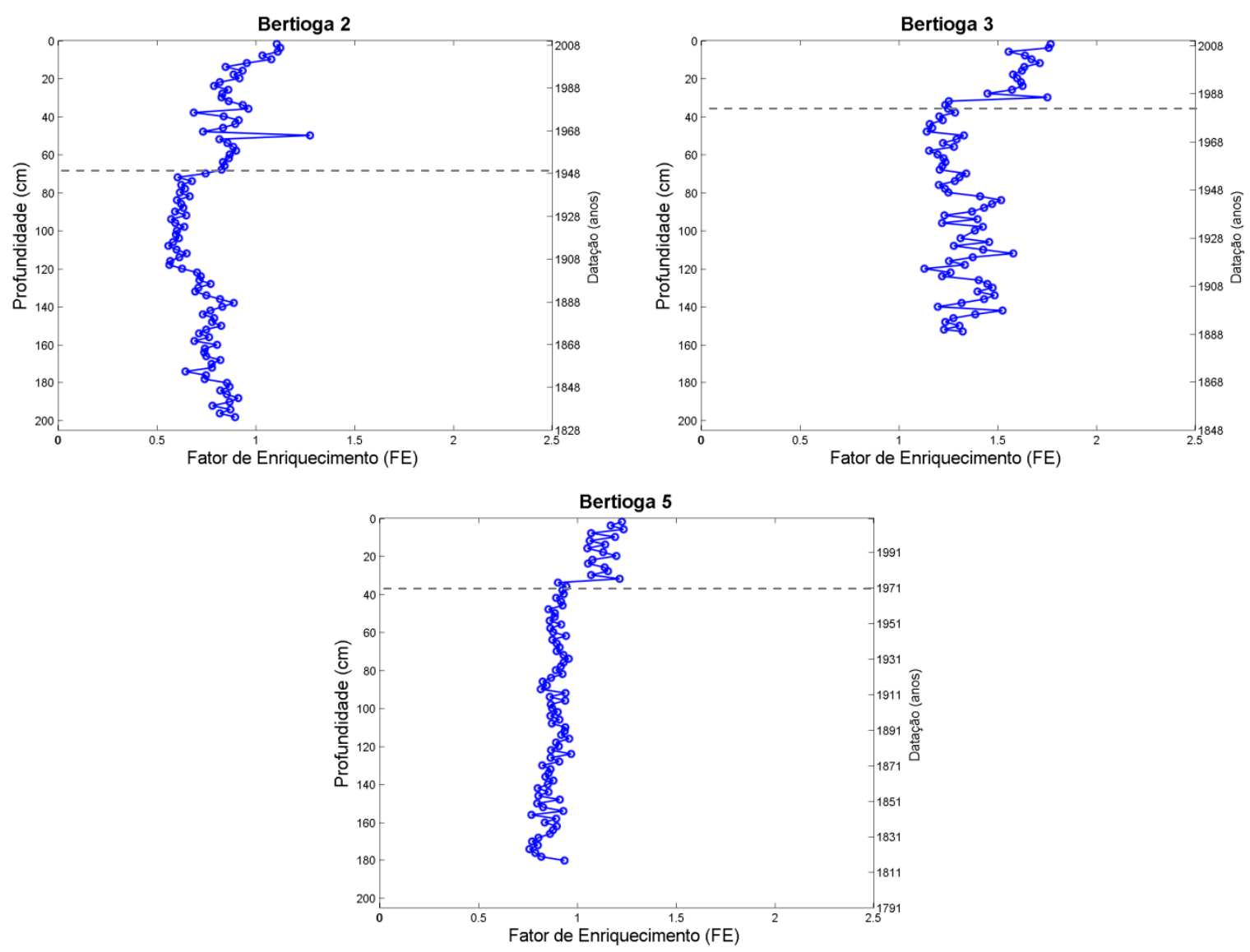

Figura 28. Perfis de fator de enriquecimento para Pb nos testemunhos Bertioga 2, 3 e 5.

Analisando os valores de $\mathrm{Zn}$ para os testemunhos localizados no Canal de Bertioga, expressos na Figura 29, pôde-se notar que este elemento apresentou comportamento distinto dos demais descritos anteriormente. Todos os testemunhos apresentaram um enriquecimento iniciado em meados da década de 1980. Esse aumento pôde indicar uma fonte antrópica desse metal no Canal de Bertioga. Alguns fatores históricos puderam justificar esse aporte. Observando os dados apresentados na tabela do Anexo 3, notou-se que em 1984 ocorreu um grande desastre ambiental na Vila de Socó, em Cubatão. Um vazamento em uma das tubulações da Refinaria Presidente Bernardes, que passava pela região gerou um incêndio com grandes reflexos ambientais. Uma segunda hipótese para esse aumento foi um acidente ambiental ocorrido em 1983, quando um oleoduto se rompeu, gerando um grande vazamento de óleo que acabou por atingir o Canal de Bertioga. 

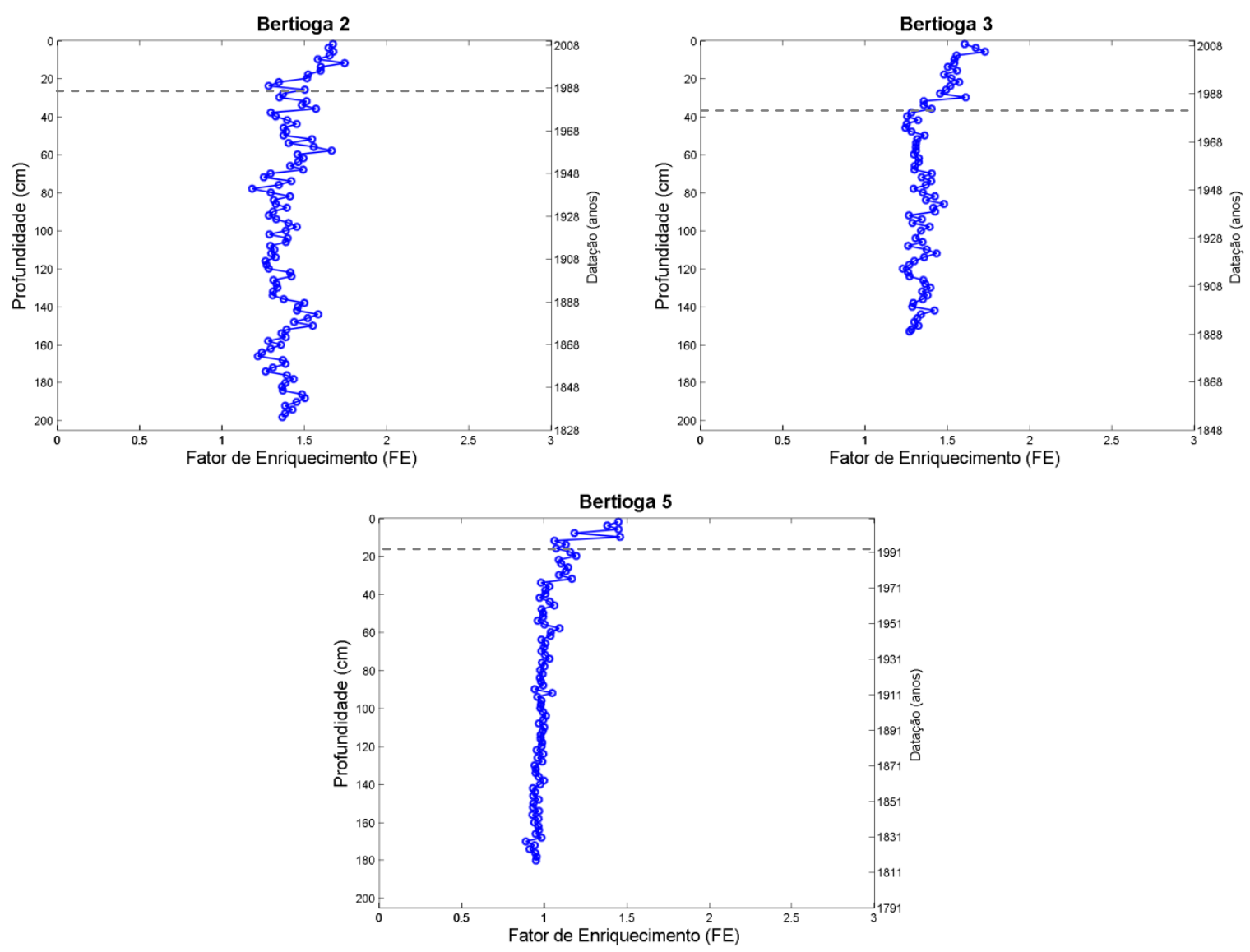

Figura 29. Perfis de fator de enriquecimento para Zn nos testemunhos Bertioga 2, 3 e 5.

Os valores de FE para $\mathrm{Hg}$, expressos na Figura 30, apresentaram enriquecimentos muito superiores aos apresentados para os demais elementos, denotando uma situação de preocupação ambiental. O grande aumento na deposição de $\mathrm{Hg}$, diferente dos metais e semimetal citados anteriormente, teve origem recente, datando da década de 1990. Os valores de FE correspondentes das camadas mais recentes indicaram uma contaminação significativa desse elemento. 

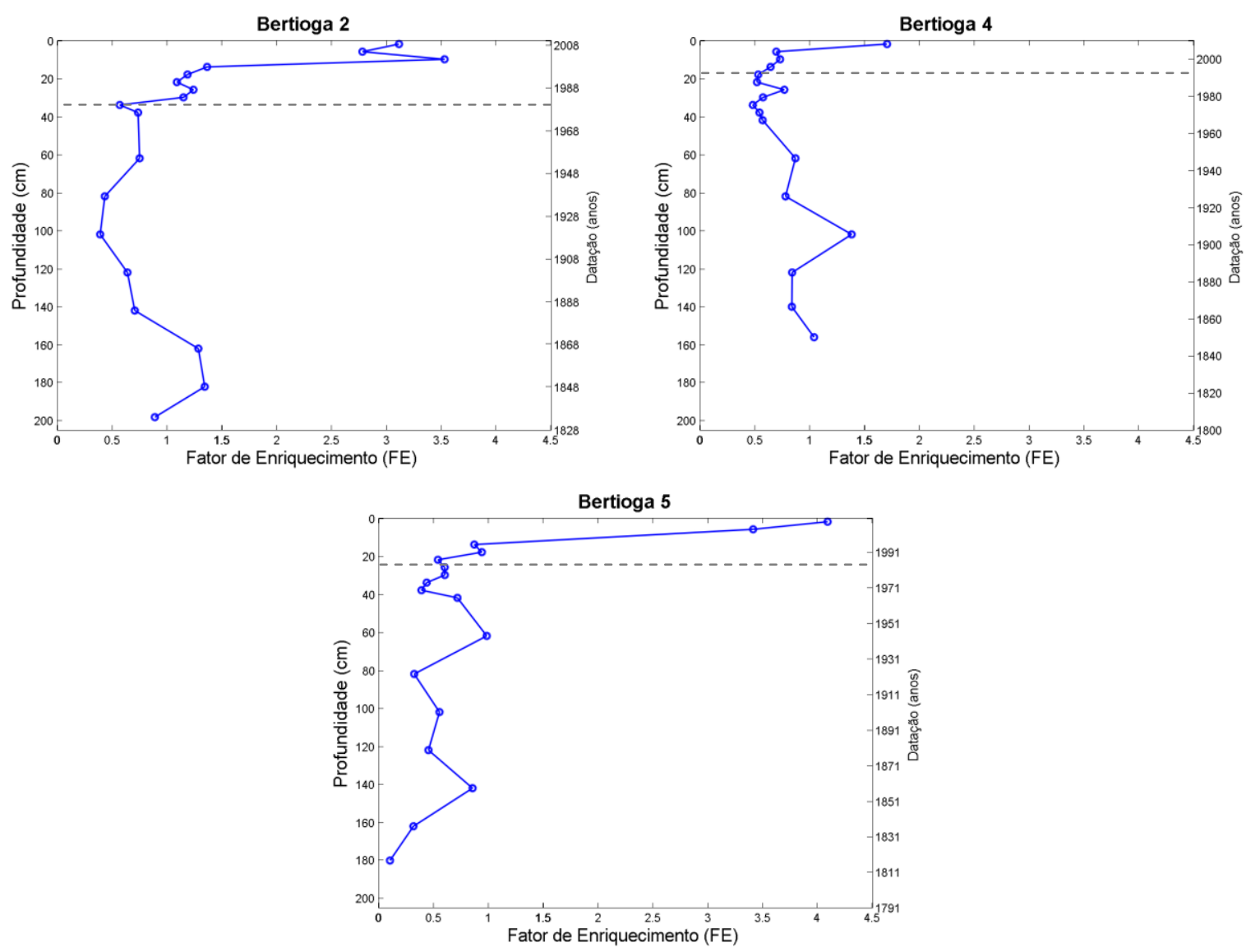

Figura 30 Perfis de fator de enriquecimento para $\mathrm{Hg}$ nos testemunhos Bertioga 2, 3 e 5.

Os perfis de valores de fator de enriquecimento para os demais elementos contaminantes podem ser encontrados no Anexo 2.

\subsubsection{A análise de contaminação dos sedimentos como reflexo do histórico ambiental no Canal de Bertioga}

A utilização dos parâmetros de poluição: Pollution Load Index (PLI) e Ecological Risk Index (RI) permitiram avaliar a qualidade dos sedimentos no que se diz respeito à contaminação por metais. Possibilitaram analisar também, o aumento da deposição dos metais ao longo dos anos e o possível reflexo no meio ambiente.

Com relação à contaminação ambiental, fica claro que a região do Canal de Bertioga apresentou baixos níveis de contaminação, não representando riscos ambientais. No entanto, ao longo dos últimos anos, observou-se um aumento significativo na deposição de metais nos sedimentos. Os valores de PLI e RI são apresentados na Figura 31 e Figura 32. Notou-se nas figuras um aumento significativo de metais nos sedimentos das porções superficiais dos 
sedimentos. O início desse aumento é sinalizado pela linha tracejada e tem data estimada, em todos os testemunhos, próxima da década de 1980.

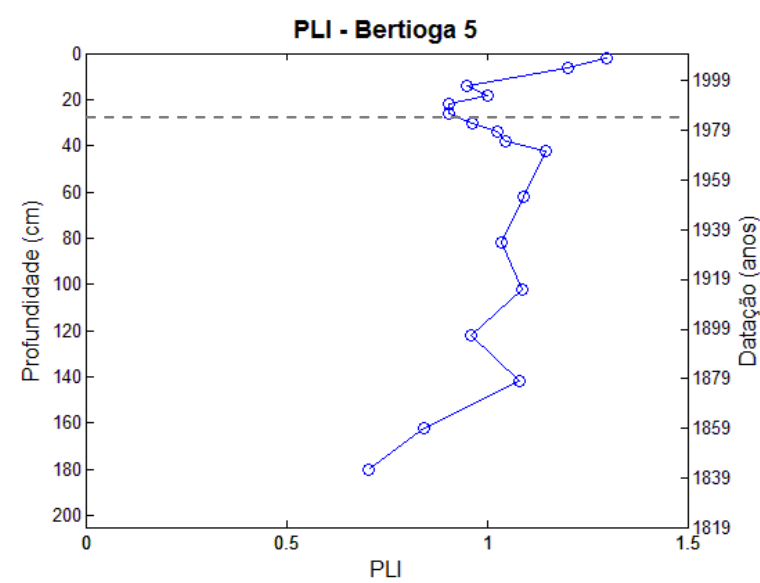

Figura 31. Valores de PLI para o testemunho Bertioga 5.

Merece destaque o testemunho Bertioga 5. Ele apresentou os maiores aumentos na deposição recente de metais. Esse acréscimo nos teores de metais pôde ser explicado pela dinâmica da região à qual a coluna sedimentar está inserida, o Largo do Candinho. Nessa porção do canal, ocorre a confluência de correntes de maré de sentido de deslocamento opostos (tombo das águas), local onde a influência da maré é praticamente nula e há grande movimento deposicional (Miranda e Castro, 1991).

Embora a origem dos metais no sedimento não possa ser claramente definida, uma das possíveis fontes destes para o sistema foi o estuário santista. Uma segunda hipótese, já citada anteriormente, foi do aumento de metais a partir dessa data, ser decorrência de um acidente que ocorreu na região.

Em 14 de outubro de 1983, por ocasião da abertura da Rodovia Rio-Santos (SP-55), uma rocha com cerca de 20 toneladas caiu sobre o oleoduto da Petrobrás, responsável pela ligação entre o TEBAR (Terminal Marítimo Almirante Barroso), em São Sebastião e a Refinaria Presidente Bernardes em Cubatão. Com o rompimento do oleoduto houve vazamento de 3,5 milhões de litros de óleo cru. Praticamente todo petróleo derramado foi drenado para o Rio Iriri, alcançou o Canal de Bertioga e atingiu extensas áreas de manguezal. (Ponte et al., 1987).

Estudos anteriores apresentaram casos de aumento na concentração de metais em sedimentos de regiões que sofreram episódios de derramamento de óleo. Ribeiro et al. (2009) 
observaram aumentos nos valores de alguns metais na região antártica que foram correlacionados com acidentes envolvendo derramamento de petróleo.
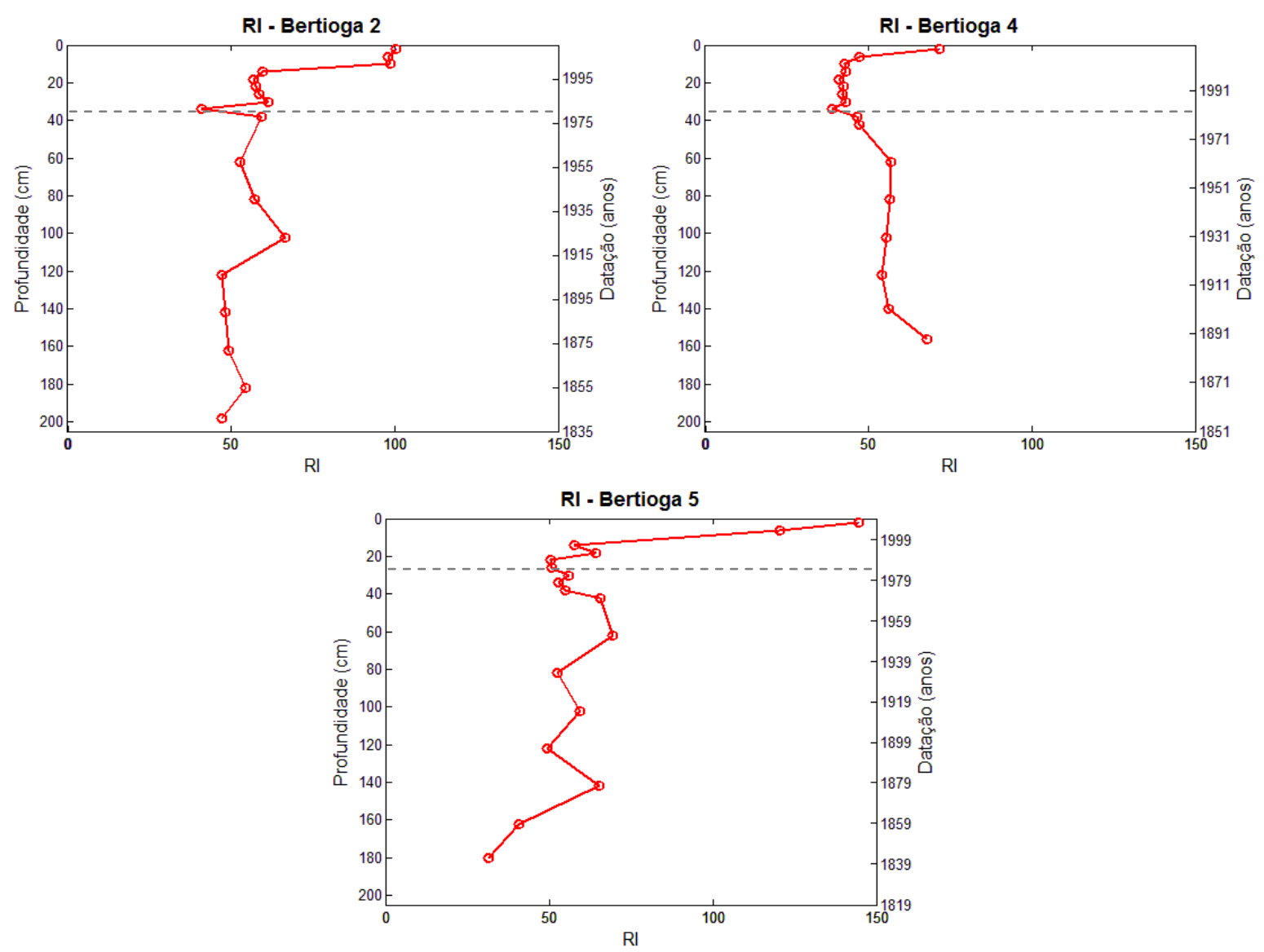

Figura 32. Valores de RI para os testemunhos Bertioga 2, 4 e 5.

Uma terceira hipótese que pôde justificar o aumento nas concentrações de metais na década de 1980 foi a Tragédia da Vila de Socó. Em 24 de fevereiro de 1984 moradores da Vila Socó (atual Vila São José), Cubatão/SP, perceberam o vazamento de gasolina em um dos oleodutos da Petrobrás que ligava a Refinaria Presidente Bernardes ao Terminal de Alemoa.

A tubulação passava em região alagadiça, em frente à vila constituída por palafitas. Devido a falhas operacionais, uma tubulação se rompeu, espalhando cerca de 700 mil litros de gasolina pelo mangue. Muitos moradores, visando conseguir algum dinheiro com a venda de combustível, coletaram e armazenaram parte do produto vazado em suas residências. Com a movimentação das marés o produto inflamável espalhou-se pela região alagada e cerca de 2 horas após o vazamento, aconteceu um incêndio. O fogo se alastrou por toda a área alagadiça superficialmente coberta pela gasolina, incendiando as palafitas. 


\subsection{Alto estuário santista}

O alto estuário santista apresentou características distintas daquelas encontradas no Canal de Bertioga. A análise dos metais e As no sistema refletiram o impacto da industrialização e urbanização desenfreada da região.

\subsubsection{Metais contaminantes no alto estuário santista}

A análise do fator de enriquecimento nos testemunhos localizados no alto estuário santista permitiu corrigir os valores de concentração a partir do elemento normalizador Sc. De maneira geral, os elementos que apresentaram perfis significativos de $\mathrm{FE}$ foram: $\mathrm{Cu}, \mathrm{Pb}, \mathrm{Hg}$ e Zn. Os quatro elementos são produtos de diversas atividades industriais.

A Figura 33 e Figura 34 apresentam os valores de FE para $\mathrm{Cu}$ e $\mathrm{Pb}$ em três dos testemunhos do alto estuário santista. Os dois elementos apresentam características coincidentes. Notou-se que houve semelhança entre os perfis das colunas sedimentares Santos 2 e Santos 8, indicando possível similaridade na fonte desses elementos para o sistema. Como sinalizado pela linha pontilhada, o início do enriquecimento de $\mathrm{Cu}$ e $\mathrm{Pb}$ datou do século 1950. Já para Santos 1, esse enriquecimento foi mais recente, com data estimada de 1995. 

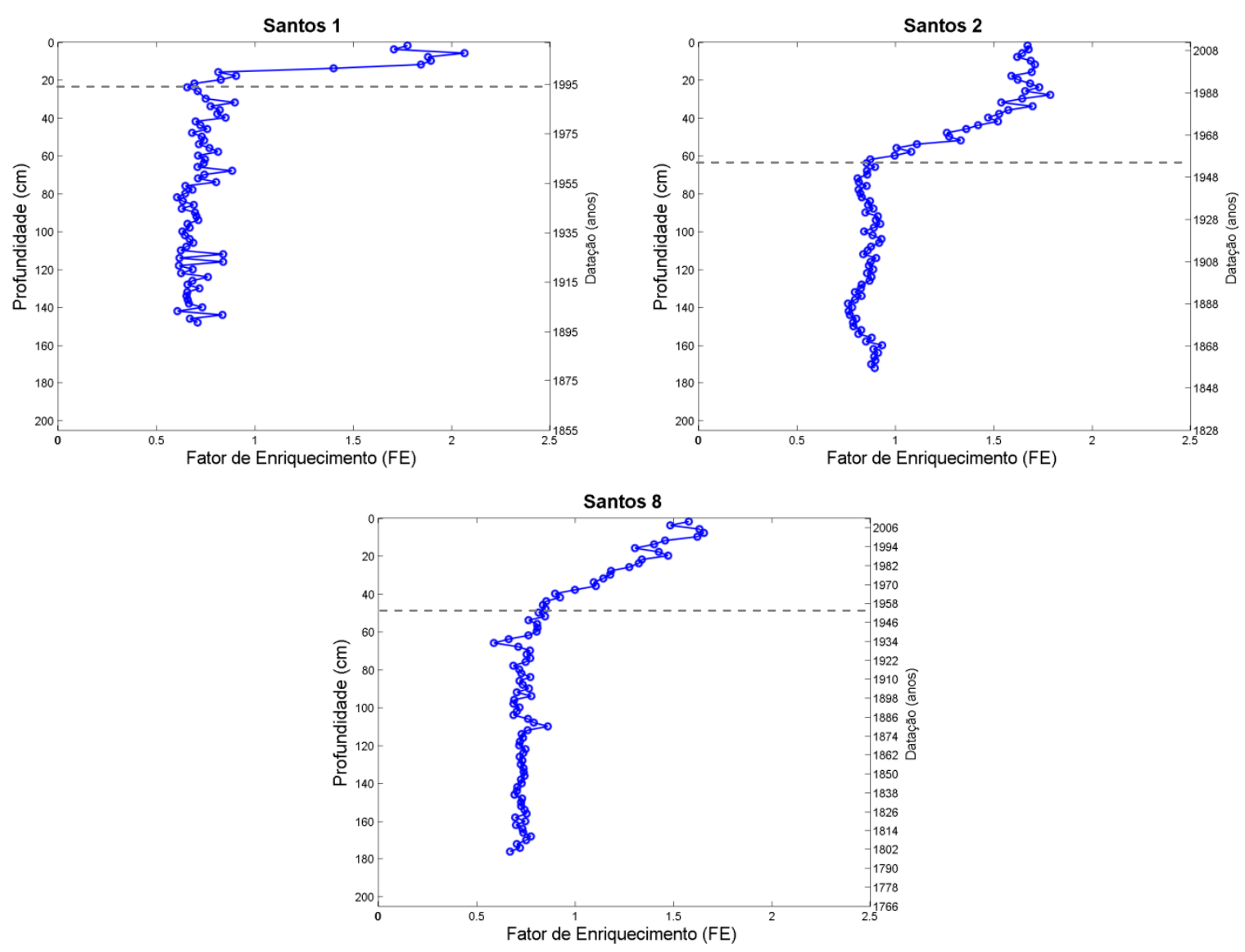

Figura 33. Perfis de fator de enriquecimento para Cu nos testemunhos Santos 1, 2 e 8.

Embora os valores de $\mathrm{FE}$ para $\mathrm{Cu}$ e $\mathrm{Pb}$ não tenham indicado contaminação por esse elemento no sistema, ficou nítida às influências antrópicas nesse ambiente. Houve um enriquecimento acentuado nas porções mais superficiais dos testemunhos, que no caso dos testemunhos Santos 2 e Santos 8 coincidiram com o período de crescimento industrial e urbano da região. Destacou-se entre os perfis apresentados, os valores superficiais do testemunho Santos 1, característicos de uma região com contaminação moderada.

Observando os valores de $\mathrm{Cu}$ e $\mathrm{Pb}$ e comparando com os dados históricos nota-se que o testemunhos Santos 2 e Santos 8 sofreram influência direta do crescimento e atividade industrial da região. Segundo tabela do Anexo 3, notou-se a partir da década de 1950 uma grande expansão industrial, que atinge seu auge por volta dos anos 1970. A partir da década de 1990 houve uma maior preocupação ambiental, que por consequência levou a uma leve melhora ambiental. Essa melhora é observada nos gráficos descritos na Figura 33 e Figura 34. 

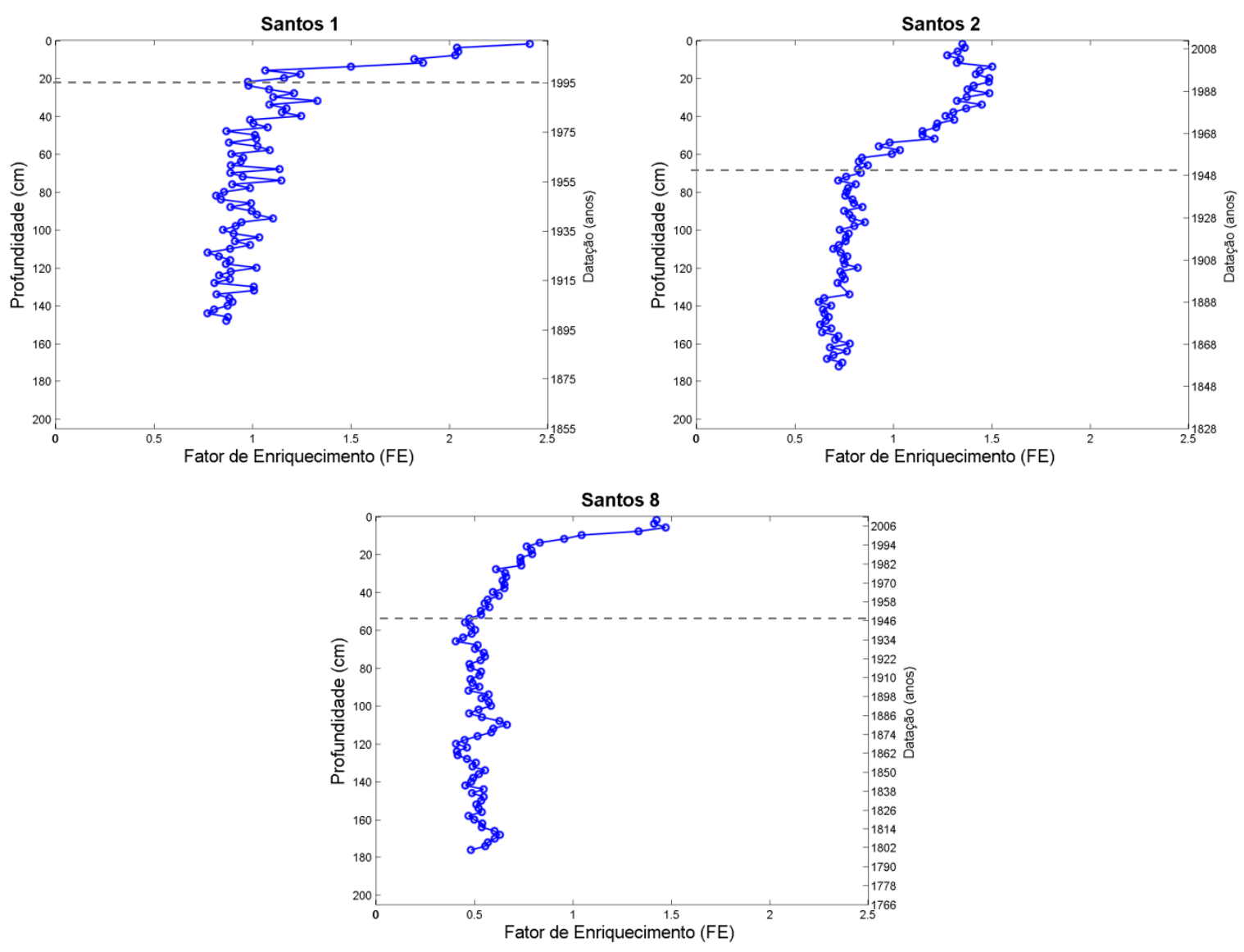

Figura 34. Perfis de fator de enriquecimento para Pb nos testemunhos Santos 1, 2 e 8.

Analisando os valores de FE para $\mathrm{Hg}$, apresentados na Figura 35, observou-se que o elemento foi o principal contaminante da região da Baixada Santista no que se diz respeito a elementos metálicos. Analisando os testemunhos individualmente, podemos notar que Santos 1 apresentou a partir da década de 1950 enriquecimento desse elemento no testemunhos, com valores de FE representativos de uma contaminação moderada. Em meados da década de 1980, passou-se a observar valores mais elevados, qualificando-se uma região de poluição significativa.

O testemunho Santos 8 está localizado próximo ao polo industrial de Cubatão. Os valores de FE para $\mathrm{Hg}$ refletiram claramente o histórico da região, sendo a contaminação reflexo do crescimento industrial. A partir do início da década de 1950, observou-se um enriquecimento de $\mathrm{Hg}$, passando a indicar um ambiente com contaminação moderada. Essa situação se manteve até o inicio da década de 1990, quando cresceu de maneira exponencial, chegando a valores indicativos de poluição significativa. 
Analisando o histórico da região de Cubatão, observou-se que algumas indústrias marcaram épocas e esse fato foi claramente notado nos perfis de FE de $\mathrm{Hg}$. Resumidamente, as primeiras fábricas, embora pequenas, começam a surgir em 1915. As primeiras grandes indústrias da região começaram a surgir na década de 1950, com a implantação da Refinaria Presidente Bernardes e início às obras de instalação da COSIPA, afetando drasticamente não só de Cubatão, mas de toda a Baixada Santista. A década de 1960 foi marcada pela inauguração de potenciais indústrias, como a COSIPA (em 1963) Carbocloro (em 1964) e Ultrafértil (em 1969). Aproveitando as vantagens locacionais, diversas pequenas e médias indústrias se instalaram e Cubatão na década de 1960 e 1970. Os anos de 1980 foram marcados por grandes problemas de poluição ambiental. No início dos anos 1990 notou-se um maior controle ambiental.

O testemunho Santos 2 apresentou os mais críticos valores de FE para $\mathrm{Hg}$, nos demonstrando nitidamente o reflexo da industrialização da Baixada Santista no meio ambiente. Os valores indicaram uma região não contaminada até o início da década de 1950, quando passaram a sofrer o reflexo de toda a atividade industrial, que nessa época se instalava na região. Até o início da década de 1980 os teores foram característicos de uma poluição significativa. A década de 1980 foi marcada por um período de enriquecimento exponencial, atingindo valores característicos de uma região extremamente poluída ainda no final dos anos 80. A partir do final da década de 1990 e início dos anos 2000 notou-se uma diminuição de FE, quando os programas de controle ambiental criados pela Cetesb na década anterior, passam a surtir efeitos no meio ambiente. Os valores mais recentes de FE foram próximos a 30, ainda indicando uma região com alta poluição de $\mathrm{Hg}$. 

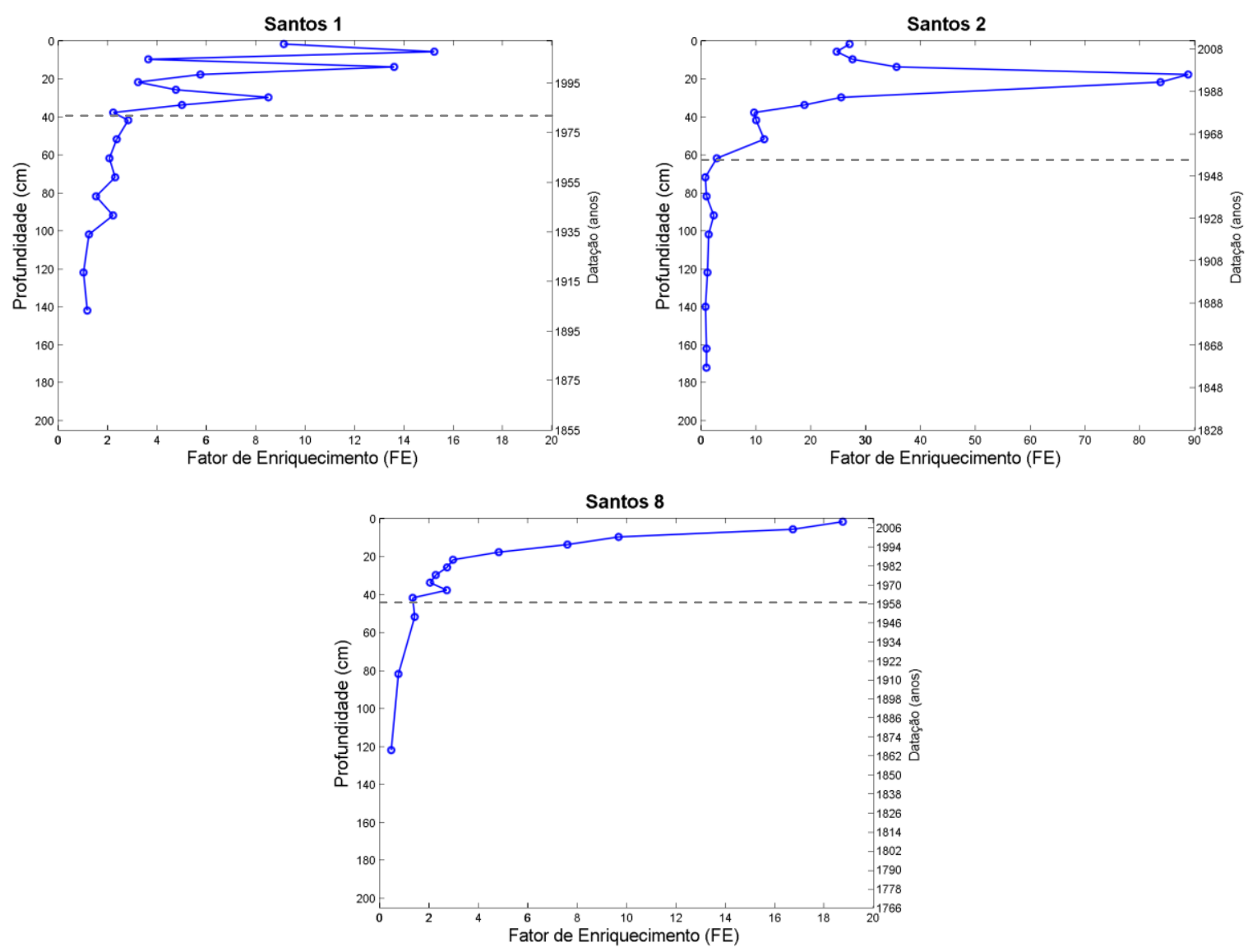

Figura 35. Perfis de fator de enriquecimento para Hg nos testemunhos Santos 1, 2 e 8.

Os perfis de FE para Zn nos testemunhos Santos 1, Santos 2 e Santos 8 foram apresentados na Figura 36 e expressaram características semelhantes àquelas apresentadas para $\mathrm{Cu}$ e $\mathrm{Pb}$. Esse elemento diferenciou-se dos demais pela data a partir da qual se dá o enriquecimento. No testemunho Santos 1, observou-se um aumento nos valores a partir do início da década de 1980, assim como Santos 8. Já em Santos 2 foi notado valores superiores a partir da década de 1950.

Atentou-se na Figura 36, um enriquecimento abrupto nos testemunhos Santos 1 e Santos 8, indicando níveis característicos de uma contaminação moderada. Já para Santos 2, embora houvesse um crescente enriquecimento desde o início das atividades industriais na região, os valores foram representativos de uma região não contaminada por $\mathrm{Zn}$. 

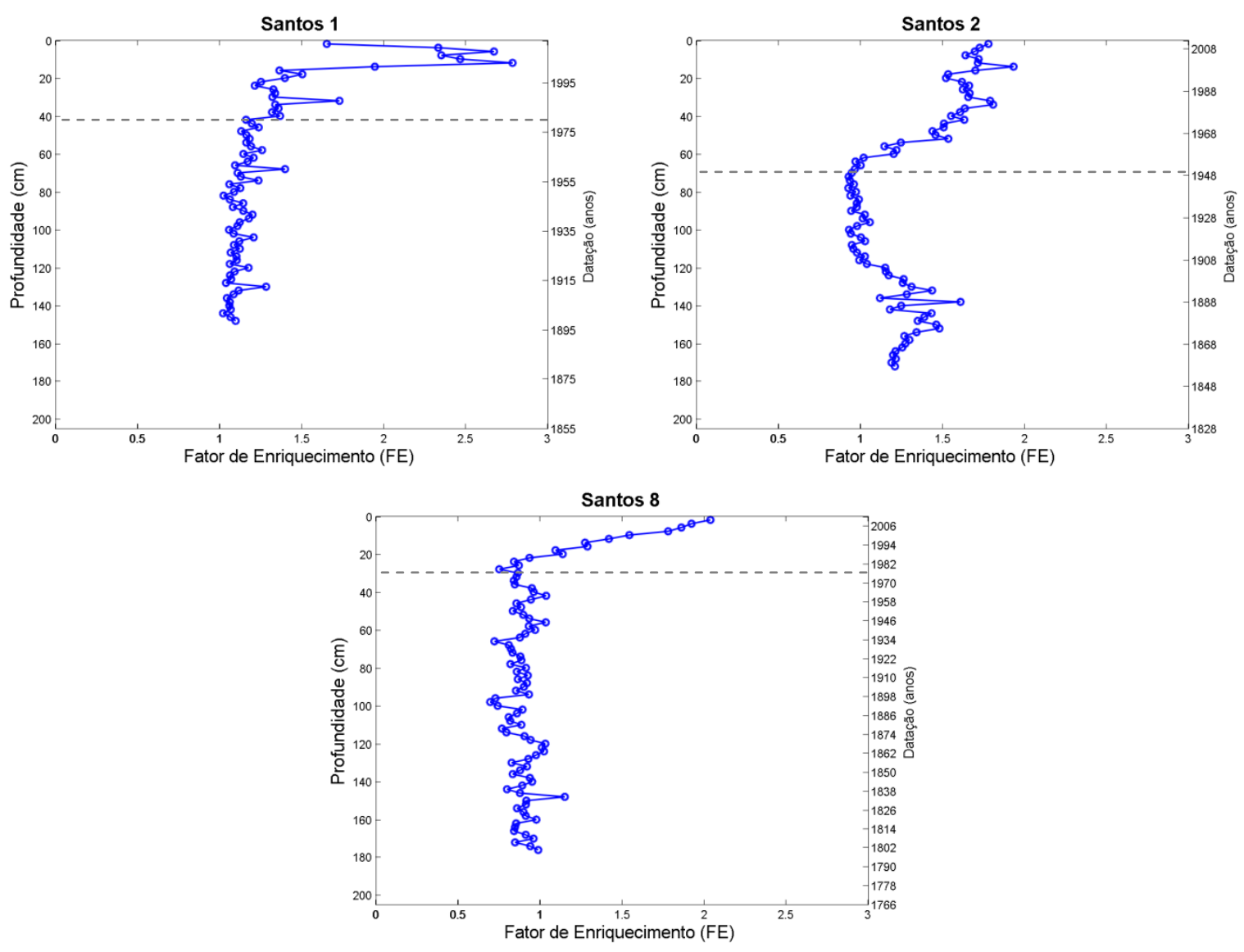

Figura 36. Perfis de fator de enriquecimento para Zn nos testemunhos Santos 1, 2 e 8.

\subsubsection{A análise de contaminação dos sedimentos como reflexo do histórico ambiental no alto estuário santista}

O parâmetro de poluição Pollution Load Index (PLI) foi apresentado na Figura 37, apontando em geral níveis preocupantes de riscos ambientais no alto estuário santista. A partir do parâmetro PLI foi possível se observar uma tendência de aumento no acúmulo de metais desde a década de 1960 no caso de Santos 2 e a partir da década de 1950 para Santos 8. Por não levar em consideração às diferenças granulométricas, Santos 2 não apresentou um padrão de contínuo aumento, assim como Santos 8. Os valores de PLI nos dois testemunhos apresentados indicam um aporte não natural.

Os valores de RI indicaram características bastante interessantes, refletindo muito do histórico de ocupação antrópica no alto estuário santista e indicando o funcionamento desse sistema deposicional. 

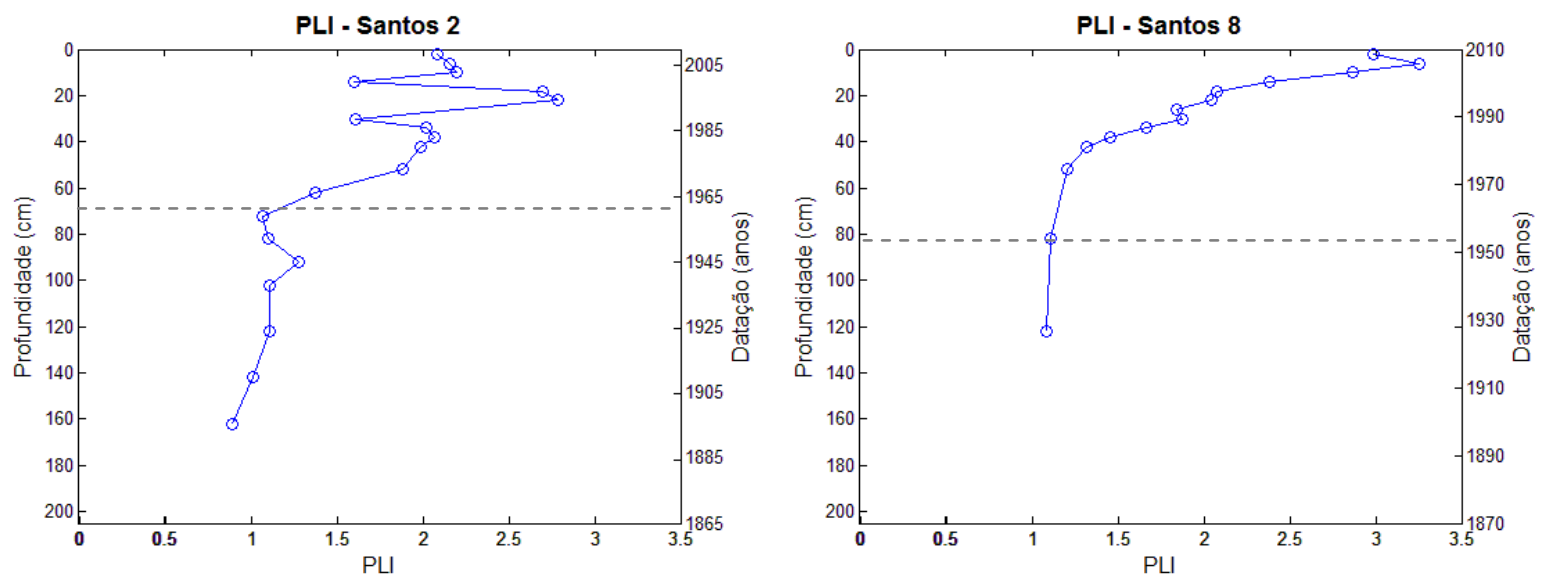

Figura 37. Valores de PLI para os testemunhos Santos 2 e Santos 8.

Santos 1 apresentou valores de RI, descritos na Figura 38, característicos de uma região com baixo risco ambiental. No entanto, observou-se um leve aumento no aporte de metais desde a década de 1980. Observando a Figura 39, que apresenta imagens históricas, notou-se que a região a qual se encontra o testemunho vem sofrendo constantes mudanças no que se diz respeito ao uso e ocupação de solo nos últimos anos.

A principal modificação observada na Figura 39 foi a implantação de um terminal portuário e ampliação de uma filial da empresa Vale. Esse terminal pôde ser observado apenas na imagem mais recente, indicando uma possível fonte de metais entre os anos de 2003 e 2012. Embora Santos 1 esteja bastante próxima ao porto de Santos, notou-se uma grande área ainda preservada com vegetação ao redor do ponto amostrado.

Os valores mais baixos de RI encontrados no testemunho Santos 1 puderam ser justificados pela dinâmica da região à qual o ponto está inserido. Observando a Figura 4, que apresenta o padrão de circulação da região, notou-se que a seção em questão pouco sofre influência das correntes provenientes do alto estuário santista. A circulação em Santos 1 é dominada por correntes provenientes do Canal de Bertioga. 


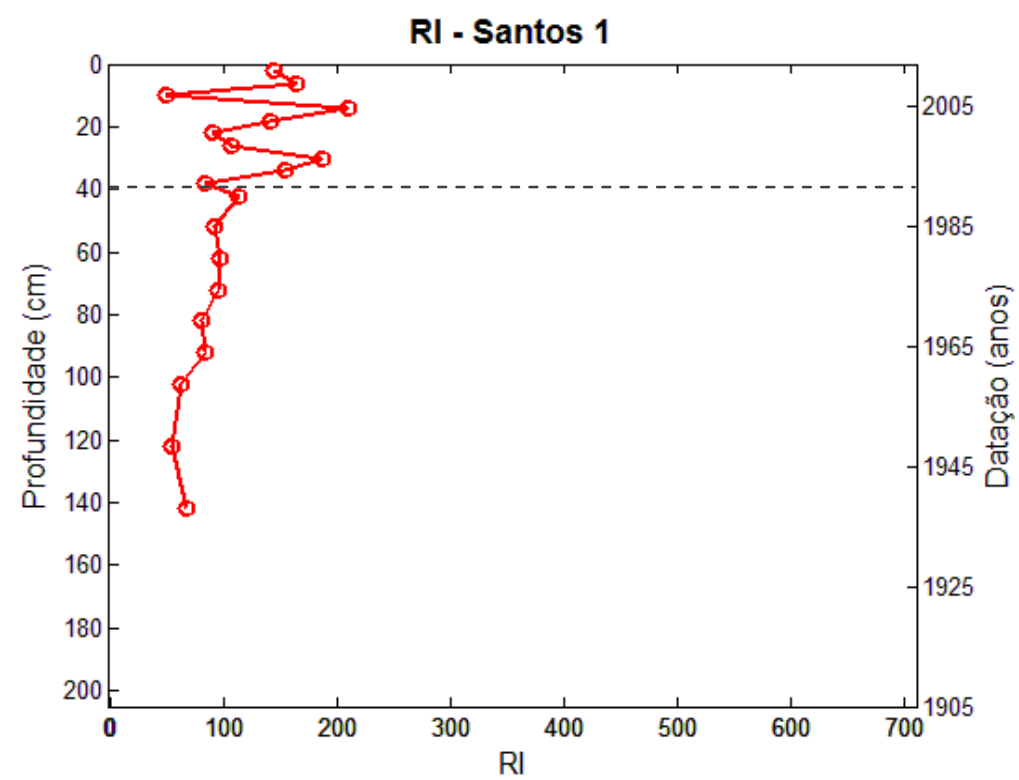

Figura 38. Valores de RI para o testemunhos Santos 1.

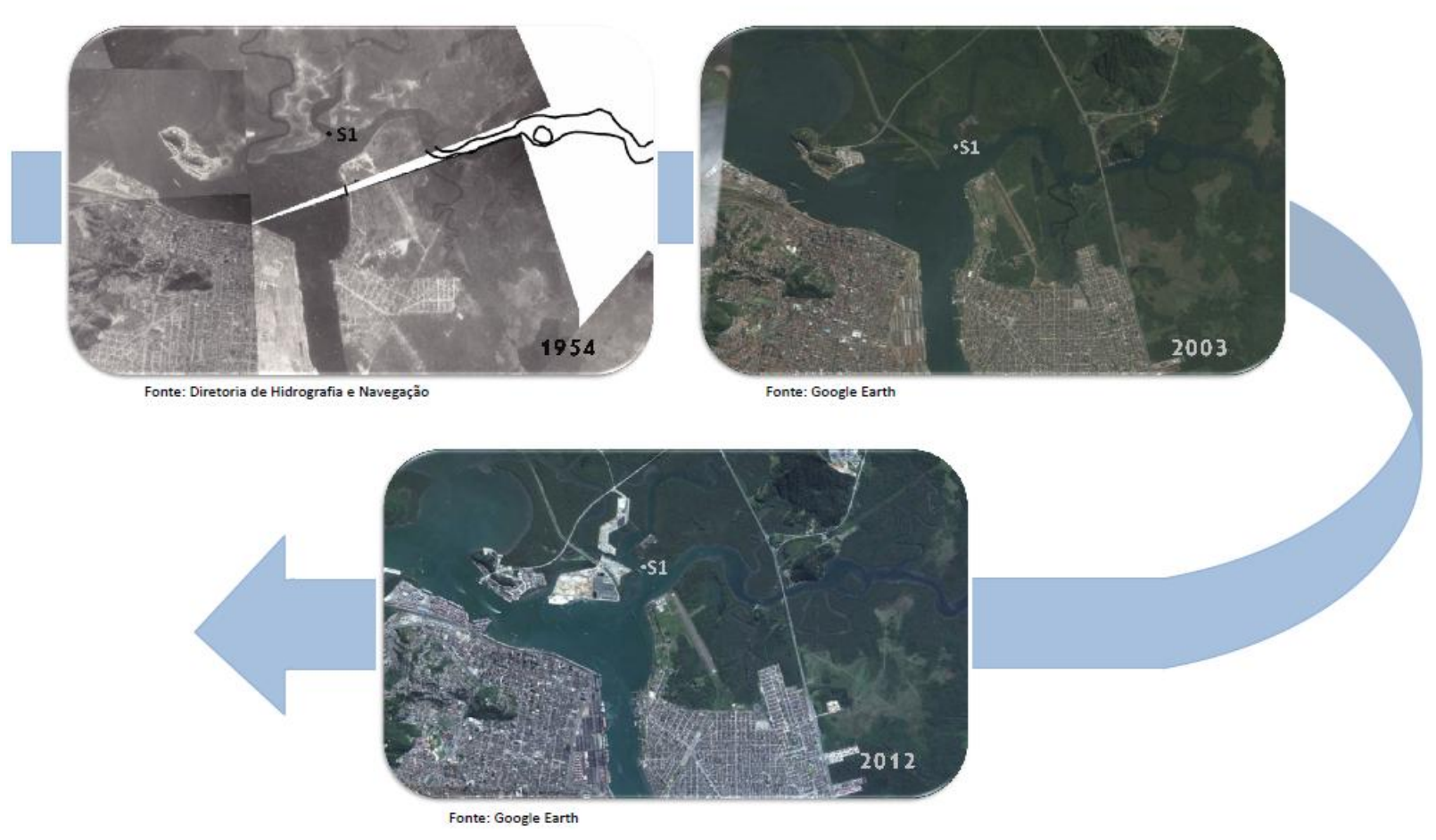

Figura 39. Imagens históricas da região a qual está inserida o testemunho Santos 1.

Santos 2 apresentou os níveis de concentrações mais preocupantes entre todos os testemunhos estudados. O perfil de RI refletiu nitidamente a influência antrópica na região, com valores que seguem o histórico da industrialização na região. Observando a Figura 40, notou-se um aumento nos valores a partir da década de 1950, quando começaram a surgir as 
mudanças mais abruptas na ocupação da região, como é o caso do início das operações do oleoduto Santos-São Paulo, a inauguração do Terminal de Carga e Descarga de Petróleo do Alemos, a inauguração da refinaria Presidente Bernardes, a criação do polo industrial de Cubatão e a criação do Complexo Siderúrgico.

A década de 1970 foi marcada pelo crescente aumento no número de empresas da Baixada Santista, o auge da expansão do polo industrial de Cubatão, a implantação do Lixão do Alemoa, a inauguração da Rodovia dos Imigrantes, a instalação de industrial de fertilizantes, a expansão imobiliária e o início da dragagem do Canal de Piaçanguera, o que refletiu na qualidade do ambiente.

Na década de 1980 ocorreram episódios de grandes problemas ambientais e de saúde pública, devido ao crescimento industrial desenfreado e pouco planejado da região e a falta de preocupação ambiental. Além de problemas com acidentes ambientais, como o ocorrido na Vila de Socó. No perfil de RI esse período foi bastante evidente, apresentando valores característicos de um alto risco ambiental. Com a criação da Cetesb, na década de 1980, diversas medidas de cuidados ambientais foram implantadas, e a partir da década seguinte, pôde se observar uma melhoria na qualidade do sedimentos. No entanto, vale ressaltar, que as porções mais superficiais do testemunho Santos 2 ainda indicam uma região de alto risco ambiental.

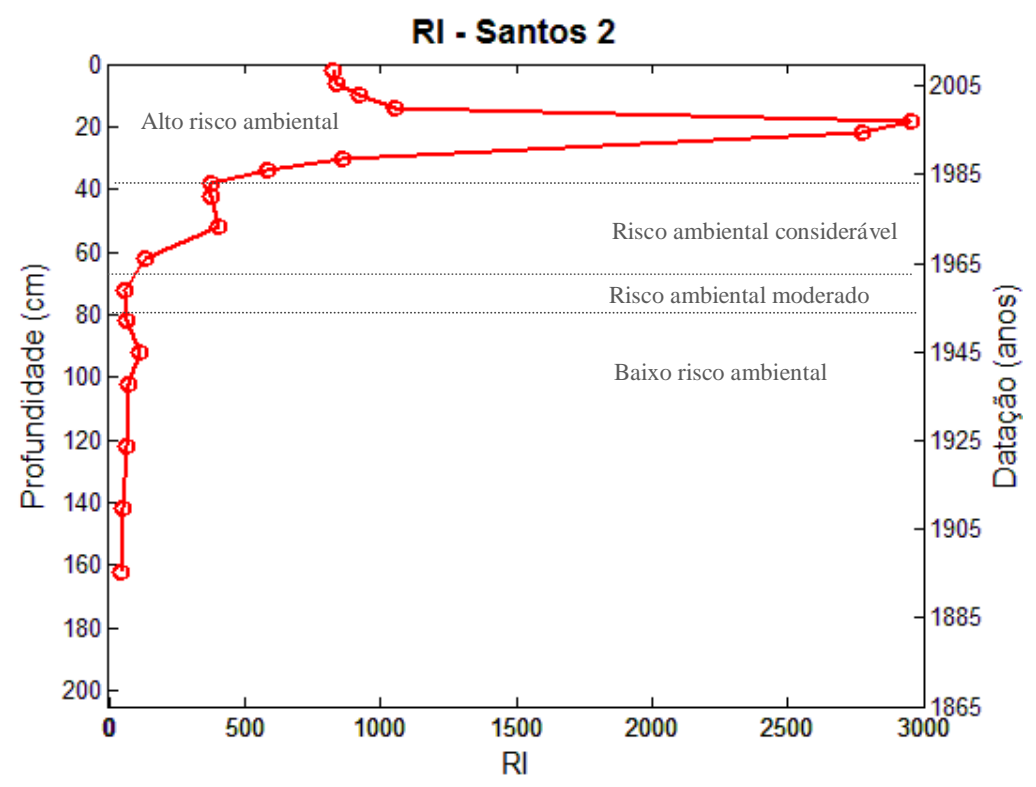

Figura 40. Valores de RI para o testemunhos Santos 2. 
Analisando as imagens históricas da região, apresentadas na Figura 41, foi possível observar, assim como na Figura 39, um aumento na ocupação de solos por indústrias locais. Grandes mudanças afetaram a região entre os anos de 2003 e 2012. Na porção direita da fotografia do ano de 2012 observou-se o mesmo terminal portuário citado anteriormente, assim como a ocupação do solo por indústrias locais. Na porção inferior esquerda verificou-se a ampliação do porto de Santos.

O fato de Santos 2 ter apresentado as maiores concentrações pôde ser explicado, assim como no caso anterior, pela dinâmica da região. Como obervado na Figura 4, Santos 2 localiza-se em uma porção do estuário abrigada e com correntes de baixa intensidade, propiciando a deposição de sedimentos finos (como observado na seção 5.1), assim como de metais e As.

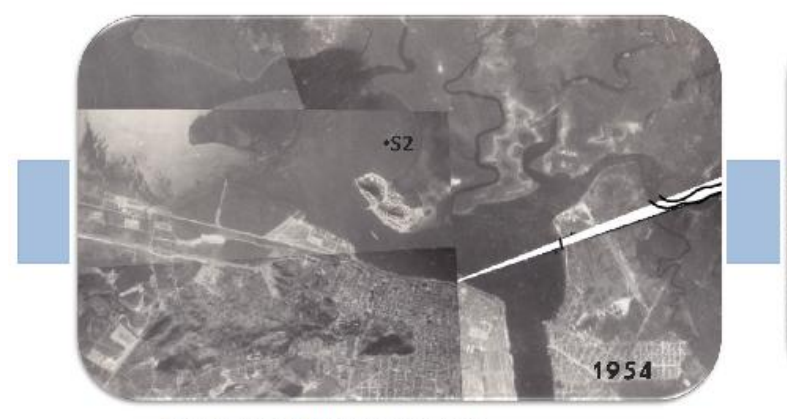

Fonte: Diretoria de Hidrografia e Navegação

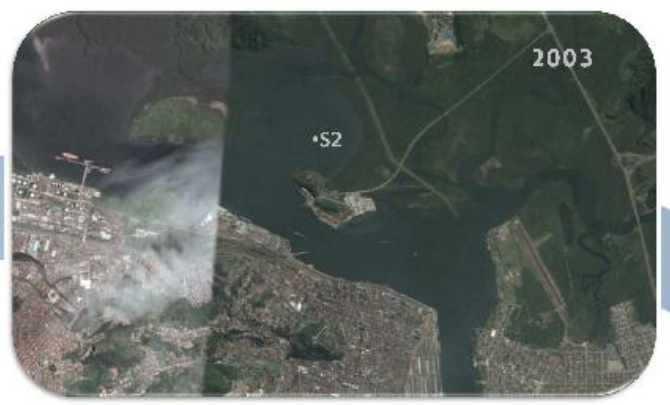

Fonte: Google Earth

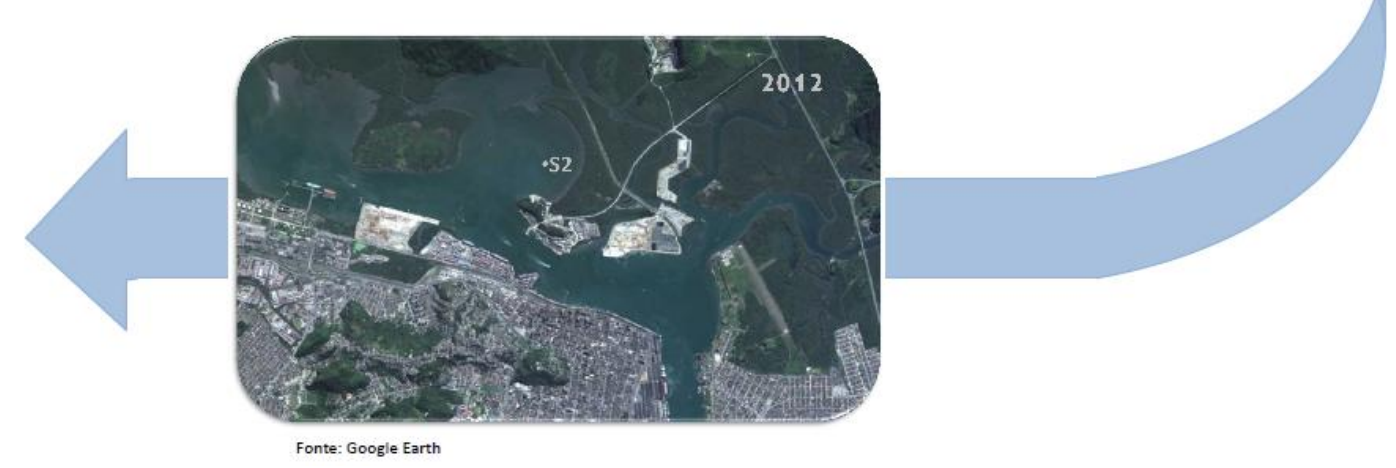

Figura 41. Imagens históricas da região a qual está inserida o testemunho Santos 2.

Observando os valores de RI para o testemunho Santos 8, expressos na Figura 42, notou-se que, assim como Santos 8, houve um crescente aporte de metais de região, iniciado na década de 1950. A partir da década de 1970, os valores de RI indicam sedimentos com um risco ambiental moderado. Houve um crescimento exponencial nos valores a partir da década de 1990, com índices atuais indicativos de um alto risco ecológico. 
Embora Santos 8 esteja mais próximo de Cubatão, os valores observados não foram os mais altos dentre os testemunhos estudados. Esse fato pôde ser explicado pela dinâmica do local, os teores de grãos finos foram os mais baixos dentre os testemunhos de Santos aqui apresentados. A taxa de sedimentação corroborou com essa informação. Santos 8 apresentou a mais baixa taxa de sedimentação dentre as colunas sedimentares estudadas em Santos. Esses dois fatores indicaram uma ambiente com correntes que dificultam a deposição e acumulação de metais no sedimento.

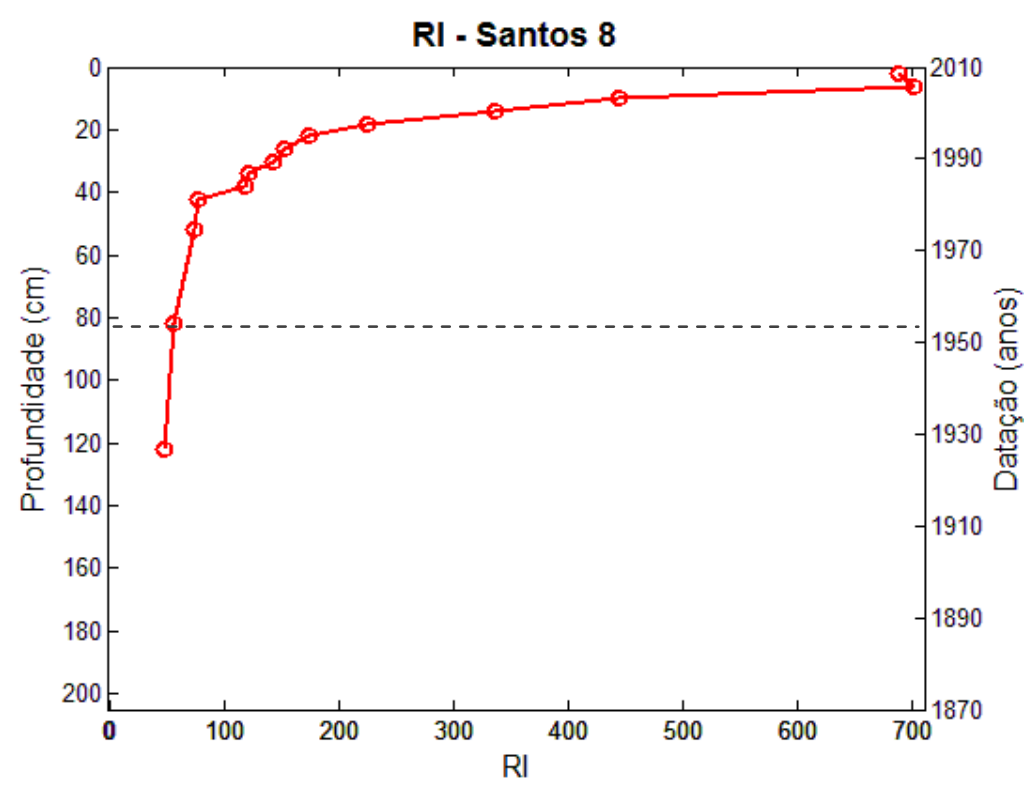

Figura 42. Valores de RI para o testemunhos Santos 8.

A ausência de imagens da região no ano de 1954 não permitiu notar a ocupação nessa região na data. Observando os anos de 2003 e 2012 não foram notadas mudanças significativas na urbanização da área. A proximidade de Santos 8 com o polo industrial de Cubatão pôde ser notada na Figura 43. Na porção superior da imagem pudemos observar a antiga COSIPA, hoje denominada USIMINAS, grande indústria da região e potencial fonte de metais para o ambiente. 


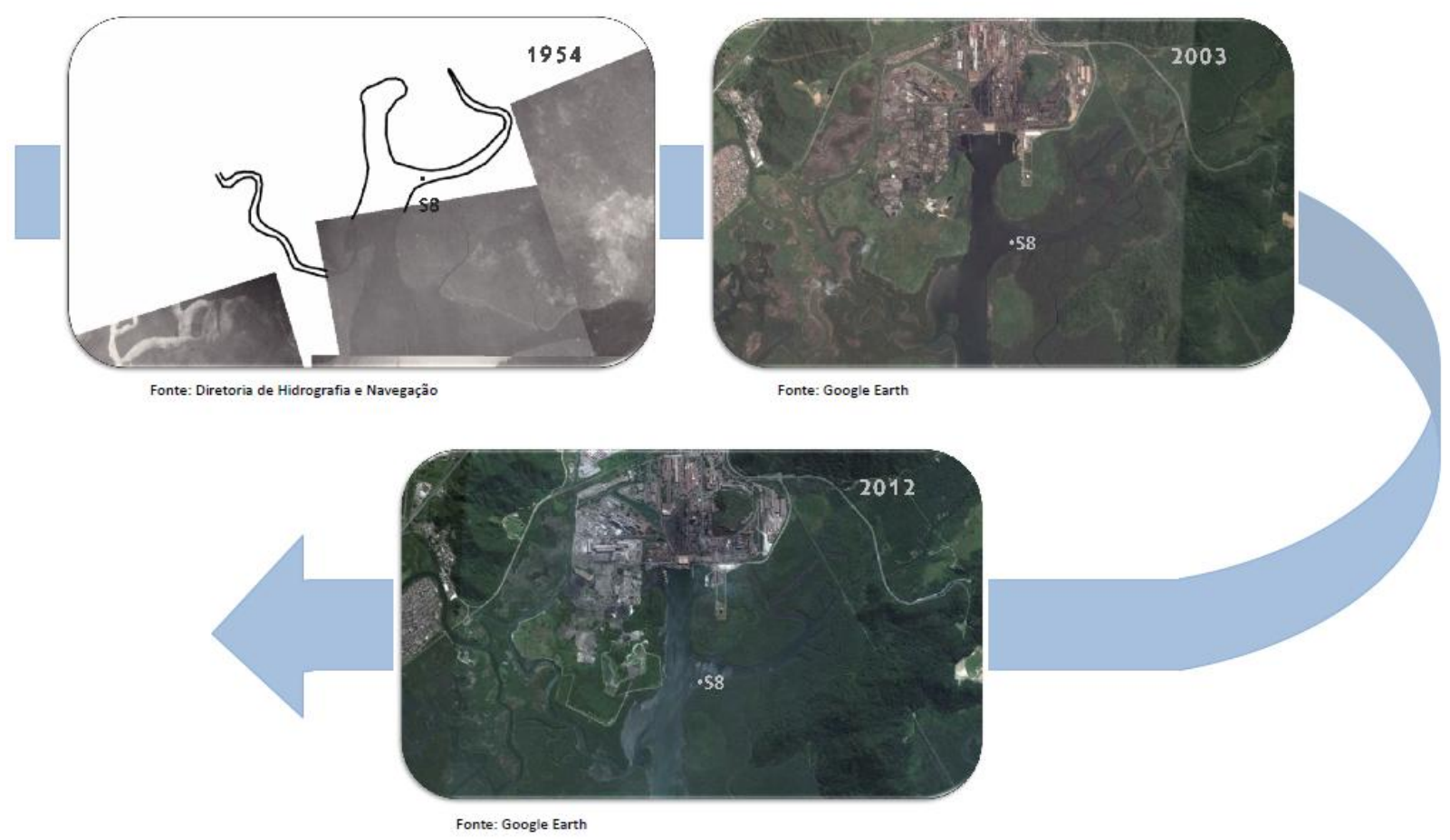

Figura 43. Imagens históricas da região a qual está inserida o testemunho Santos 8. 


\section{Considerações Finais e Conclusão}

O presente trabalho teve como objetivo o levantamento histórico da região do Estuário de Santos e São Vicente a partir da analise de metais e As no sedimento. Para atingir tal objetivo foram analisados os teores obtidos a partir da digestão parcial de sedimentos de nove testemunhos. Valores de background da região foram calculados a partir da digestão total das amostras de base dos testemunhos e foram utilizados para o cálculo de parâmetros de poluição.

Inicialmente, observou-se uma distinção entre as concentrações obtidas para os testemunhos localizados no Alto Estuário Santista em relação ao Canal de Bertioga. Para o Canal de Bertioga, os valores encontrados estiveram em sua maioria abaixo dos níveis de TEL e Nível 1 da Resolução Conama 454 (2012). Apenas o elemento As apresentou valores acima de PEL, o que pode ser explicado pelos altos níveis naturais desse elemento nas rochas brasileiras.

No caso dos testemunhos localizados em Santos, observaram-se valores acima de TEL em alguns pontos para Ni e Zn. Um grande aumento superficial foi notado também para os elementos $\mathrm{Cu}$ e $\mathrm{Pb}$, caracterizando uma fonte antrópica desses elementos para o sistema, embora ainda não sejam considerados contaminantes.

Destacou-se no Estuário Santista os valores de Hg. As concentrações desse metal no sistema sofreram um acréscimo exponencial nos últimos anos, atingindo valores superiores a TEL na porção superficial de todos os testemunhos e, em alguns pontos, valores superiores a PEL.

Observando o histórico das regiões contrapondo com os valores de metais, observouse que, no Canal de Bertioga, há um recente acréscimo no teor dos elementos estudados, com destaque para $\mathrm{Cu}, \mathrm{Hg}, \mathrm{Pb}$ e $\mathrm{Zn}$, a partir da década de 80. Embora os valores de metais nessa região não indiquem uma contaminação no sedimento, o aumento no topo dos testemunhos é característico de uma influência antrópica na região. As possíveis fontes para esses metais são: o alto estuário santista e um derramamento de óleo ocorrido na década de 1980.

Os maiores teores de metais no Canal de Bertioga foram observados em Bertioga 5. O fato pôde ser justificado pela localização do testemunho. A coluna sedimentar localiza-se no Largo do Candinho, região onde acontece o encontro das correntes de maré provenientes de Bertioga e do Estuário Santista, propiciando a deposição de sedimentos finos. 
Para o Estuário de Santos, observou-se uma influência da industrialização e urbanização da região anterior à apresentada em Bertioga. Desde a década de 50 notou-se um aumento nos teores de metais, com um acentuado acréscimo a partir da década de 1970, reflexo da grande atividade industrial de região. O auge da poluição por metais ocorre na década de 1990, quando se nota o reflexo dos programas ambientais iniciados na década anterior no ecossistema. Os elementos mais preocupantes no Estuário Santista são: $\mathrm{Cu}, \mathrm{Hg}, \mathrm{Pb}$ e $\mathrm{Zn}$. Com destaque para $\mathrm{Hg}$, que apresentou níveis altíssimos de contaminação a partir dos parâmetros de poluição calculados.

Os testemunhos que apresentaram níveis mais altos dentro do Estuário de Santos foram Santos 2 e Santos 8. Santos 2 apresentou os mais altos valores, que possivelmente são justificados pela dinâmica do local ao qual está inserido, com baixas circulações e grande deposição de sedimentos finos. Santos 8 igualmente apresentou valores preocupantes, sendo esses justificados pela proximidade do polo industrial de Cubatão. 


\section{Referências Bibliográficas}

ABESSA, D. M. 2002. Avaliação da qualidade de sedimentos do Sistema Estuarino de Santos. Tese de Doutorado. Universidade de São Paulo, Instituto Oceanográfico, 209 p.

AGUIAR, V. M. C. 2005. Variação espacial e temporal das características biogeoquímicas do fósforo e do chumbo e transporte de propriedades no sistema estuarino de Santos / São Vicente e na porção Sul do complexo estuarino-lagunar de Cananéia-Iguape (São Paulo). Tese de Doutorado. Universidade de São Paulo, Instituto Oceanográfico, 243p.

ALMEIDA, F. F. M.; CARNEIRO, C. D. R. 1998. Origem e Evolução da Serra do Mar. Rev. Bras. Geociências, v. 28, n.2, p.135-150.

ANDREWS, S.; SUTHERLAND, R. A. 2004. Cu, Pb and $\mathrm{Zn}$ contamination in Nuuanu watershed, Oahu, Hawaii. The Science of the Total Environment, v. 324, p. 173-182.

APPLEBY, P. G.; OLDFIELD, F., 1992. Application of Lead-210 to sedimentation studies. In: IVANOVICH, M.; HARMON, R. S. (Eds.), Uranium-Series disequilibrium. New York: Oxford Science, p. 731-778, 1992.

BORGES, A. C. ; DIAS, J.C. ; MACHADO,W. ; PATCHINEELAM, S.R. 2007. Distribuição espacial de ferro, cobre e chumbo em sedimentos de manguezal em um gradiente de degradação da Baía de Guanabara (estado do Rio de Janeiro). Química Nova, v. 30 n. 1, p. 66-69.

BRYAN, G. W. 1971. The effects of heavy metals (other than Mercury) on marine and estuarine organisms. Proc. Roy. Soc. Lond. B., v. 177, p. $389-410$.

BURUAEM, L. M. ; CASTRO, I. B. ; HORTELlANI, M. A. ; TANIGUCHI, S ; FILLMANN, G. ; SASAKI, S. T. ; PETTI, M. A. V. ; SARKIS, J, E. S. ; BÍCEGO, M. C. ; MARANHO, L. A.; DEVANSO, M. B. ; NONATO, E. F. ; CESAR, A. ; 
COSTA-LOTUFO L. V. ; ABESSA, D. M. S. 2013. Integrated quality assessment of sediments from harbour areas in Santos- São Vicente Estuarine Sytem, Southern Brazil. Costal and Shelf Science, v. 130. p 179-189.

CAEIRO, S.; COSTA, M. H.; RAMOS, T. B.; FERNANDES, F.; SILVEIRA, N.; COIMBRA, A.; MEDEIROS, G.; PAINHO, M. 2005. Assessing heavy metal contamination in Sado Estuary sediment: An index analysis approach. Ecological Indicators, v. 5, p. 151-169.

CARDOSO, A. G. ; BOAVENTURA, G. R. ; SILVA FILHO, E. V. ; BROAD, J. 2001. Metal distribution in sediments from the Ribeira Bay, Rio de Janeiro. Brazil. Journal of the Brazilian Chemical Society, v.12, p. 767-774.

CARMO, C. A.; ABESSA, D. M. S. ; NETO, J. G. M. 2011. Metais em águas, sedimentos e peixes coletados no estuário de São Vicente-SP, Brasil. O Mundo da Saúde, v. 35, n. 1, p. 64-70.

CARVALHO GOMES, F. C.; GODOY, J. M.; GODOY, M. L. D. P.; CARVALHO,Z. L .; LOPES, R. T.; SANCHEZ-CABEZA, J. A.; LACERDA,L. D. WASSERMAN, J. C. 2009. Heavy metals in sediments profiles from Sepetiba and Ribeira Bays: A comparative study. Radioprotection, v. 44, n 5 . p. 243-250.

CELINO, J. J.; OLIVEIRA, M. C.; HADLICH. G. M.; QUEIROZ, A. F. S.; GARCIA, K. S. 2008 Assentment of contamination by trace metals and petroleum hydrocarbons in sediments from the tropical estuary of Todos os Santos Bay, Brazil. Revista Brasileira de Geociências, v.38, n.4, p.753-760.

CEQG - Canadian Environmental Quality Guidelines. 2001. Canadian Sediment Quality Guidelines for the Protection of Aquatic Life. Disponível em <ceqgrcqe.ccme.ca.download/en/239/>.

CETESB, COMPANHIA DE TECNOLOGIA DE SANEAMENTO AMBIENTAL. 2001. Sistema Estuarino de Santos e São Vicente. Relatório Técnico, 178 p. 
CETESB, COMPANHIA DE TECNOLOGIA DE SANEAENTO AMBIENTAL. 2013. Relatório de monitoramento de águas superficiais no Estado de São Paulo. Relatório técnico. 443p.

CHOUERI, R. B.; CESAR, A.; TORRES, R. J.; ABESSA, D. M. S.; MORAIS, R. D.; PEREIRA, C. D. S.; NASCIMENTO, M. R. L.; MOZETO,, A. A.; RIBA, I.; DELVALLS, T. A. 2009. Integrated sediment quality assessment in Paranaguá Estuarine System, Southern Brazil. Ecotoxicology and Environmental Safety. v. 72, p. $1824-1831$.

CLARK, M. W.; DAVIES-MCCONCHIE, F.; MCCONCHIE, D.; BIRCH, G. F. 2000. Selective chemical extraction and grainsize normalization for environmental assessment of anoxic sediments: validation of in integrated procedure. Science Total Environment, p.258-149.

CONSELHO NACIONAL DO MEIO AMBIENTE (CONAMA). 2012. Resolução 454, de 01 de novembro de 2012. http://www.mma.gov.br.

CORREIA, P. B. 1994. Paleomagnetismo e anisotropia de susceptibilidade magnética do complexo intrusivo Itaqui, Estado de São Paulo. Tese de Doutorado. Universidade de São Paulo, Instituto Astronômico e Geofísico. 115p.

DEKKERS, M. J. 1997. Environmental magnetism: an introduction. Geol. Mijnbouw, v. 76, p.163-182.

DHN. 1997. Tábua de marés. Rio de Janeiro - RJ. Diretoria de Hidrografia e Navegação. $194 \mathrm{p}$.

EICHLER, P. P. B. 2001. Avaliação e diagnóstico do Canal de Bertioga (São Paulo, Brasil) através da utilização de foraminíferos como indicadores ambientais. Tese de Doutorado. Universidade de São Paulo, Instituto Oceanográfico, 256p. 
FERREIRA, P. A. L. Aplicação do modelo de migração vertical de ${ }^{137}$ Cs para o cálculo de taxas de sedimentação recentes em ambientes costeiros. 2014. Dissertação de Mestrado. Universidade de São Paulo, Instituto Oceanográfico, 104 p.

FERRER, L. M; R. HYPOLITO. 2001. Mobilidade de mercúrio no manguezal de Cubatão/SP. In: Anais do VIII Congresso Brasileiro de Geoquímica \& I Simpósio de Geoquímica do Mercosul, Curitiba/Paraná.

FIGUEIRA, R. C. L.; SILVA, L. R. N.; FIGUEIREDO, A. M. G.; CUNHA, I. I. L. 1998. Instrumental analysis by gamma spectrometry of low level Cs-137 in marine samples. In: Goiânia, ten years later, Vienna.

FÖRSTNER, U.; SALOMONS, W. 1980. Trace metals analysis on polluted sediments. Part I: Assessments of sources and intensities. Environ. Technol. Lett., v.1, p. 495-505.

FUKUMOTO, M. M. 2007. Determinação da história deposicional recente do Alto Estuário Santista, com base nos teores de metais e na susceptibilidade magnética dos sedimentos. Tese de Doutorado. Universidade de São Paulo, Instituto Oceanográfico, $123 \mathrm{p}$.

FÚLFARO, V. J.; PONÇANO, W. L. 1976. Sedimentação atual estuário e baía de Santos: um modelo geológico aplicado a projetos de expansão da zona portuária. In: Congresso Brasileiro de Geologia e Engenharia, 1. Anais. Rio de Janeiro, ABGE, p. 67-90.

GEORGEAUD, V; Y. NOACK; P. ROCHETTE \& D. WILLIAMSON. 1994. Magnetic parameters versus heavy metals in present day particles from the Etang de Berre. Annales Geophysicae. Part I. Solid Earth Geophysics \& Natural Hazards, v.12, n.1, C.164.

GESAMP. 1995. Joint Group of Experts on the Scientific Aspects of Marine Environment Protection Biological Indicators and their use in the Measurement of the Condition of the Marine Environment. Reports and Studies, 56 p. 
HAKANSON, L., 1980. An ecological risk index for aquatic pollution control. A sedimentological approach. Water Res., v.14, p. 975-1001.

HANESCH, M. \& R. SCHOLGER. 2002. Mapping of heavy metal loadings in soil by means of magnetic susceptibility measurements. Environ. Geol., v.42, p.857-870.

HARIKUMAR, P. S.; NASIR, U. P.; MAJEEBU, R. 2009. Distribution of heavy metals in the core sediments of a tropical wetland system. Int. J. Env. Sci. Tech., v. 6, n. 2, p. 225-232.

HARARI, J.; MESQUITA, A. R.; MARONE, E.; FRANÇA, C. A. S.; CAMARGO, R.; PEREIRA, J. E. R.; ADÃO, C. J. G. P.; SÁ JUNIOR, I. L. 1990. Tehnical report of the Project Flow measurement in the Bay of Santos. FUNDESPA. São Paulo. 56 p.

HORTELLANI, M. A.; SARKIS, J. E. S.; BONETTI, J.; BONETTI, C. 2005. Evaluation of Mercury Contamination in Sediments from Santos- São Vicente Estuarice System, São Paulo State, Brazil. Journal of the Brazilian Chemical Society, v.16. n.6a. p.1140-1149.

HORTELlANI, M.A.; SARKIS, J.E. S.; ABESSA, D. M. S.; SOUSA, E. C. P. M. 2008. Avaliação da contaminação por elementos metálicos dos sedimentos do estuário de Santos, São Vicente. Química Nova, v.31, p.10-19.

IPT - INSTITUTO DE PESQUISAS TECNOLÓGICAS. 1981. Mapa Geológico do Estado de São Paulo. 2 volumes. Governo do Estado de São Paulo. Secretaria da Indústria, Comércio, Ciência e Tecnologia, v. 1, 126p.

KERSTEN, M.; FÖRSTNER, U. 1995. Speciation of Trace Metals in Sediments and Combustion Waste. Chemical Speciation in the Environment, Blackie Academic \& Professional, Glascow.

KNOPPERS, B.; EKAU, W. E FIGUEIREDO, A.G. 1999. The coast and shelf of east and northeast Brazil and material transport. Geo-Marine Letters, v.19, n.3, p. 171-178. 
KUMAR, S. P.; EDWARD, J. K. P. 2009. Assessment of metal concentration in the sediment cores of Manakudy estuary south west coast of India. Indian Journal of Marine Sciences, v. 38, n.2, p.235-248.

KUTNER. A. S. 1976. Levantamentos sedimentológicos de apoio na pesquisa e reconhecimento de áreas poruárias. In: Congresso Brasileiro de Geologia de Engenharia, Rio de Janeiro, 1976. Anais.Rio de Janeiro, Associação Brasileira de Geologia de Engenharia, v. 2, p.47-65.

LACERDA, L. D.; BIDONE, E. D.; GUIMARÃES, A.F.; PFEIFFER, W.C. 1994. Mercury Concentration in Fish from the Itacaiunas-Paraopebas River System, Carajás region, Amazon. Anais da Academia Brasileira de Ciências, v.3, p.66-72.

LACERDA, L. D.; MARINS, R. V. 2006. Geoquímica de sedimentos e o monitoramento de metais na plataforma continental nordeste oriental do Brasil. Geoch. Bras., v.20, n.1, p. 123-135.

LIU, W. X.; LI, X. D.; SHEN, Z. G.; WANG, D. C.; WAI, O. W. H.; LI,Y. S. 2003. Multivariate statistical study of heavy metal enrichment in sediments of the Pearl River Estuary. Environmental Pollution., v. 121, p.377-388.

MAHIQUES, M. M.; FIGUEIRA, R. C. L.; SALAROLI, A. B.; ALVES, D. P. V.; GONÇALVES, C. 2013. 150 years of anthropogenic metal input in a Biosphere Reserve: the case study of the Cananéia-Iguape coastal system, Southearstern Brazil. Environ Earth Sci, v. 68, n.4, p. 1073-1087.

MARTINS, C. C. 2005. Marcadores Orgânicos Geoquímicos em testemunhos de sedimento do Sistema Estuarino de Santos e São Vicente, SP: um registro histórico da introdução de hidrocarbonetos no ambiente marinho. Tese de Doutorado. Universidade de São Paulo, Instituto Oceanográfico, 237 p. 
MIRANDA, L. B.; CASTRO, B. M. 1991. Condições oceanográficas no Canal de Bertioga. Relatório Técnico. Fundação de Estudos e Pesquisas Aquáticas (FUNDESPA), p. 197.

NETO, J, A. B.; GINGELE, F. X.; LEIPE, T.; BREHME, I. 2006. Spatial distribution of heavy metals in surficial sediments from Guanabara Bay: Rio de Janeiro, Brazil. Environmenal Geology, v. 49, p 1051-1063.

NULMAN, A. A. \& P. V. MESHCHERYAKOV. 1994. Magnetic susceptibility of soils in zone of EURT as characterisation of ecological conditions of pedosoils. Annales Geophysicae. Part I. Solid Earth Geophysics \& Natural Hazards, v. 12, n.1, C165.

OLDFIELD, F. 1991. Environmental magnetism - a personal perspective. Quat. Sci. Rev., v.10, p.73-85.

OLIVEIRA, R.C. 2009. Ambiente costeiro - fragilidades e impactos relacionados a ação antrópica: o cenário da baixada santista no estado de São Paulo/ Brasil. In: Encontro latino americano de geógrafos, 12., 2009. Montevideo, Uruguai. Anais do Encontro Latino Americano de Geógrafos, São Paulo, 2009.

PEREIRA, M. E.; DUARTE, A. C.; MILLWARD, G. E.; ABREU, S. N.; VALE, C. 1998. An estimation of industrial mercury stored in sediments of a confined area of the Lagoon of Aveiro (Portugal). Water. Sci. Techol, v.37, n.6, p.125-130.

PONTE, A.C.E.; FONSECA, I.A.Z.; CLARO, S.M.C.A. 1987. Impacto por petróleo no manguezal do Canal da Bertioga - Estrutura da vegetação. In: Simpósio sobre ecossistemas da costa sul e sudeste brasileira, 1., Cananéia, 1987. Síntese dos conhecimentos. São Paulo, Academia de Ciências do Estado de São Paulo, Publicação ACIESP 54, v.2, p.138-147.

QUINÁGLIA, G. A. 2006. Caracterização dos níveis basais de concentração de metais nos sedimentos do sistema estuarino da Baixada Santista. Tese de Doutorado. Universidade de São Paulo, Instituto de Química, 239 p. 
RAVICHANDRAN, M.; BASKARAN, M.; SANTSCHI, P. H.; BIANCHI, T. S. 1995. History of trace-metal pollution in Sabine - Neches estuary, Beaumount, Texas Environ Sci Technol, v.29, n.6, p.1495-1503.

RIBEIRO, A, P.; FIGUEIRA, R. C. L.; MARTINS, C. C.; SILVA, C. R. A.; FRANÇA, E. J.; BÍCEGO, M. C.; MAHIQUES, M. M.; MONTONE, R. C. 2011. Arsenic and trace metal contents in sediment profiles from the Admiralty Bay, King George Island, Antarctica. Marine Pollution Bulletin., v. 62, p. 192-196.

SALOMONS, W.; FÖRSTNER, U. 1984. Metals in the Hidrocycle. Berlin: SpringerVerlag.

SAITO, R. T. ; FIGUEIRA, R. C. L.; TESSlER, M. G.; CUNHA, I. I. L. 2001. Geochronology of sediments in the Cananeia-Iguape Estuary and in southern continental shelf of São Paulo State, Brazil. J. Radioanal. Nucl. Chem., v. 250, n. 1, p. 109-15.

SCHAEFFER-NOVELLI, Y. 1986. Rompimento de Oleoduto. Avaliação de impacto ambiental. Canal de Bertioga, SP. Vistoria ad Perpetuam Rei Memoriam. Relatório Técnico. (peritagem judicial. Medida cautelar antecipatória de prova). Comarca de Santos, SP, $1^{\text {a }}$ Vara Cível.

SILVA, W. L.; MACHADO, W.; MATOS, R. H. R. 2008. Multi-Elemental Contamination and Historic Record in Sediments from the Santos- Cubatão Estuarine System, Brazil. Journal of the Brazilian Chemical Society, v. 19, n.8, p. 1490-1500.

SIQUEIRA, G. W.; G. M. F. DUCATTI \& E. S. BRAGA. 2001. Avaliação de metais pesados $(\mathrm{Pb}, \mathrm{Cr}, \mathrm{Cu}, \mathrm{Fe}$ ) no sistema estuarino de Santos/São Vicente e Baía de Santos (São Paulo/Brasil). Anais do IX Congresso Latino Americano sobre Ciência del Mar. Colômbia, p:305 Cd-Ron.

SIQUEIRA, G. W \& E. S. BRAGA. 2002. Distribuição sazonal e biodisponibilidade de metais pesados $(\mathrm{Cu}, \mathrm{Pb}$ e $\mathrm{Zn})$ nos sedimentos do sistema estuarino de Santos/São 
Vicente e Baía de Santos-São Paulo/Brasil. Simpósio Brasileiro de Oceanografia/IOUSP Cd- Ron.

SIQUEIRA, G. W. 2003. Estudo dos teores de metais pesados e outros elementos em sedimentos superficiais do Sistema Estuarino de Santos (Baixada Santista - São Paulo) e da Plataforma Continental do Amazonas (margem continental norte). Tese de Doutorado. Universidade de São Paulo, Instituto Oceanográfico. 329p.

SIQUEIRA, G. W.; MENDES, A. S.; LIMA, W. N.; APRILE, F. M.; MAHIQUES, M. M.; BRAGA, E. S. 2003. Evolução do impacto ambiental causado por matéria orgânica, mercúrio e arsênio nos sedimentos de fundo do Sistema Estuarino de Santos (São Paulo). Anais do IX Congresso Brasileiro de Geoquímica. Belém/PA.

SIQUEIRA, G. W.; LIMA, W. N.; MENDES, A. S.; APRILE, F. M.; BRAGA, E. S.; MAHIQUES, M. M. 2004. Evolução do impacto ambiental causado por matéria orgânica, mercúrio e arsênio nos sedimentos de fundo do sistema estuarino de Santos. Revista Geochimistry Brasil, v.18, n.1, p. 54-63.

SOARES, M. L. G. 1997. Estudo da massa aérea de manguezais do sudeste do Brasil Análise de Modelos.. Tese de Doutorado. Universidade de São Paulo, Instituto Oceanográfico, 294p.

SOARES, H. M. V. M.; BOAVENTURA, R. A. R.; MACHADO, A. A. S. C.; ESTEVES DA SILVA, J. C. G. 1999. Sediments as monitors of heavy metal contamination in the Ave river basin (Portugal): multivariate analysis of data. Environmental Pollution, v.105, p. 311-323.

SUGUIO, K. 1973. Introdução a Sedimentologia. Edgar Blücher / EDUSP, São Paulo, 317 p.

SUGUIO, K.; MARTIN, L. 1978. Quaternary marine formation of the states of São Paulo and Southern Rio de Janeiro. In: INTERNATIONAL SYMPOSIUM ON COASTAL EVOLUTION IN THE QUATERNARY, São Paulo. Brasilian National Working Group for the IGCP SP, 55p. 
SZEFER, P.; KUSAK, A.; SZEFER, K.; GLASBY, G. P.; JANKOWSKA, H.; WOLOWICZ, M. \& ALI, A. A. 1998. Evaluation of the anthropogenic influx of metallic pollutants into Puck Bay, southern Baltic. Appl. Geochem., v. 13, p. 293-304.

TANNER, P. A.; LEONG, L. S.; PAN, S. M. 2000. Contamination of Heavy Metals in Marine Sediment Cores from Victoria Harbour, Hong Kong. Marine Pollution Bulletin, v.40, n.9, p 769-779.

TEMPLETON, D. M.; ARIESE, F.; CORNELIS, R.; DANIELSSON, L. G.; MUNTAU, H.; LEEUWEN, H. P. V.; LOBINSKI, R. 2000. Guidelines for Terms Related to Chemical Seciation and Fractionation of Elements. Definitions, Structural Aspects, and Methodological Approaches (IUPAC Recommendations 200). Pure Appl. Chem., v. 72, n.8, p. 1453-1470.

TOGNELLA, M. M. P. 1995. Valoração econômica: estudo de caso para o ecossistema manguezal- Bertioga e Cananéia, São Paulo. Dissertação de Mestrado. Universidade de São Paulo, Instituto Oceanográfico, 160p.

TOMLINSON, D. C.; WILSON, J, G.; HARRIS, C. R.; JEFFERY, D. W. 1980. Problems in the assessment of heavy metals levels in estuaries and the formation of a pollution index. Helgol. Wiss. Meeresunters, v. 33, n. 1-4, p. 566-575.

TOMMASI, L. R. 1979. Considerações ecológicas sobre o Sistema Estuarino de Santos, São Paulo. Tese de Livre Docência. Universidade de São Paulo, São Paulo, 2 vols. 489p.

TORRES, R.J. 2007. Efeitos da dragagem sobre a qualidade de sedimentos contaminados do canal de Porto de Santos: Biodisponibilidade e toxicidade de metais e compostos orgânicos persistentes. Tese de Doutorado. Universidade de São Paulo, Centro de Ciências exatas e de Técnologia, 177p. 
UNEP. 1995. Manual for the Geochemical Analyses of Marine Sediments and Suspended Particulate Matter. Reference Methods for Marine. Pollution Studies, United Nations Environment Program (UNEP),n. 63.

USEPA (United States Environmental Protection Agency). 1994. Method 7471A. Mercury in solid or semisolid waste (manual cold-vapor technique). Revision 1.

USEPA (United States Environmental Protection Agency). 1996. Method 3050B. Acid digestion of sediments, sludges and soil. Revision 2.

USEPA (United States Environmental Protection Agency). 1996. Method 3052. Microwave assisted acid digestion of siliceous and organically based matrices. Revision 0 .

VEROSUB, K. I.; A. P. ROBERTS. 1995. Environmental magnetism: past, present and future. J. Geophys. Res., v.100, p.2175-2192.

WADE, T. L.; CANTILLO, Y. A. 1994. Use of standards and reference material in the measurement of chlorinated hydrocarbon residues. Chemestry Workbook. NOAA. Technical Memorandus NOS ORCA 77, Silver Spring, Marylan, 59 p. 
ANEXO 1

PERFIS DE CONCENTRAÇÃO 
Alumínio (Al)
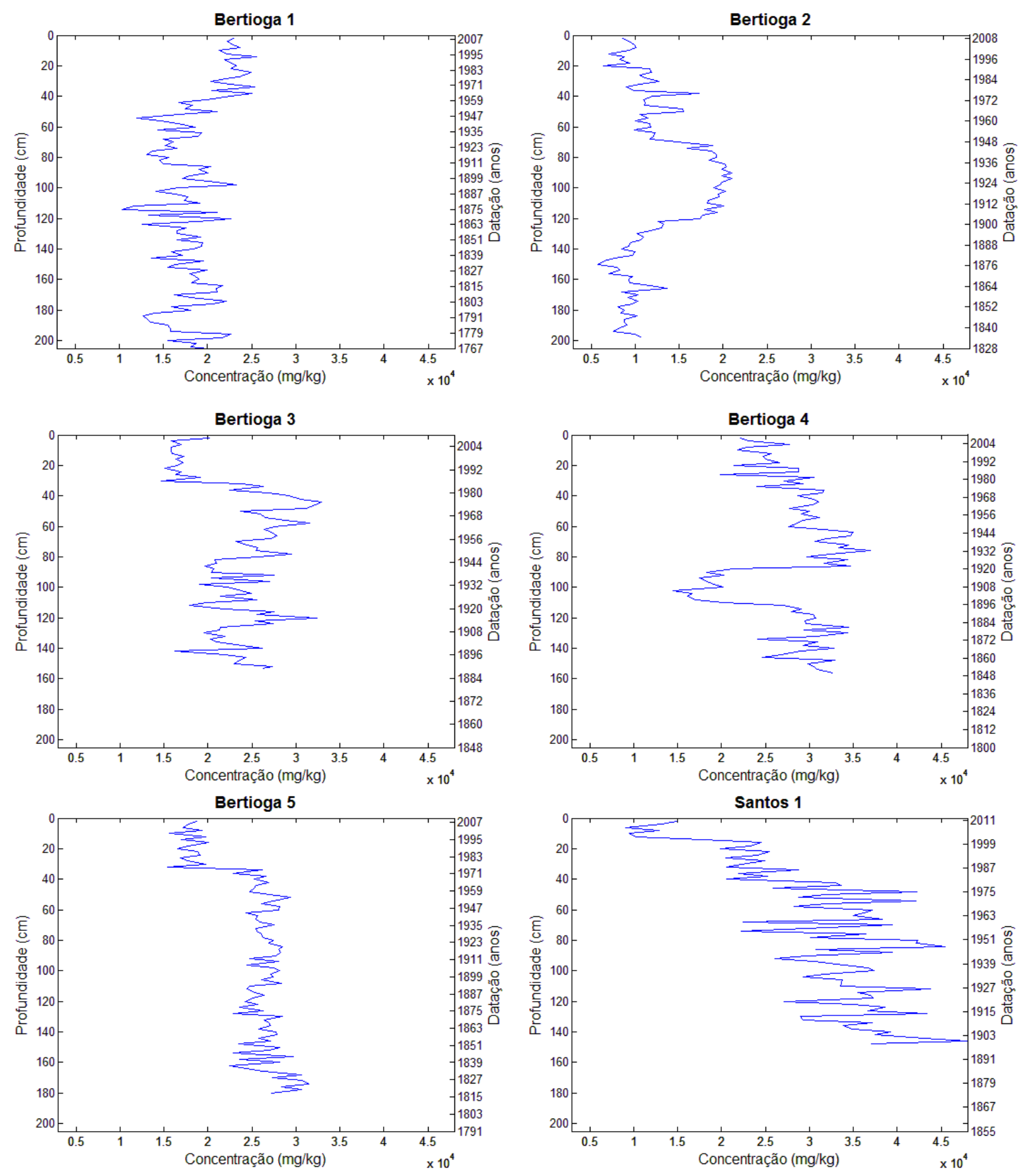

Valores de concentração de Al ( $\mathrm{mg} / \mathrm{kg})$ para os testemunhos estudados 

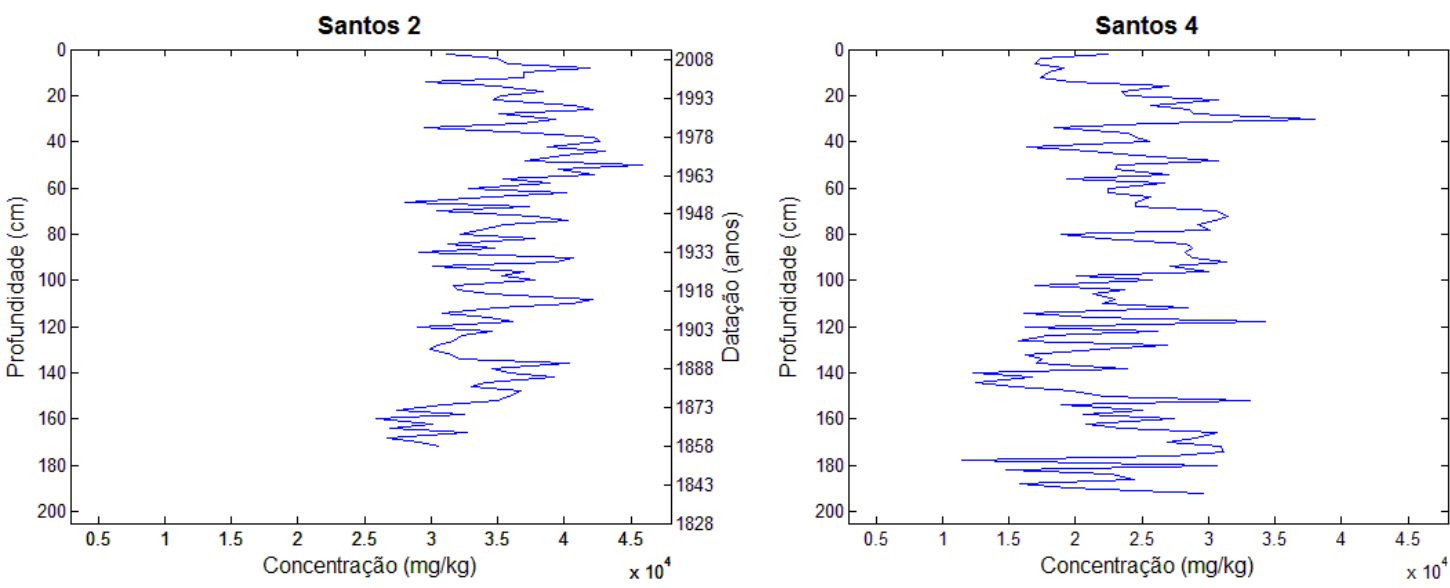

Santos 8

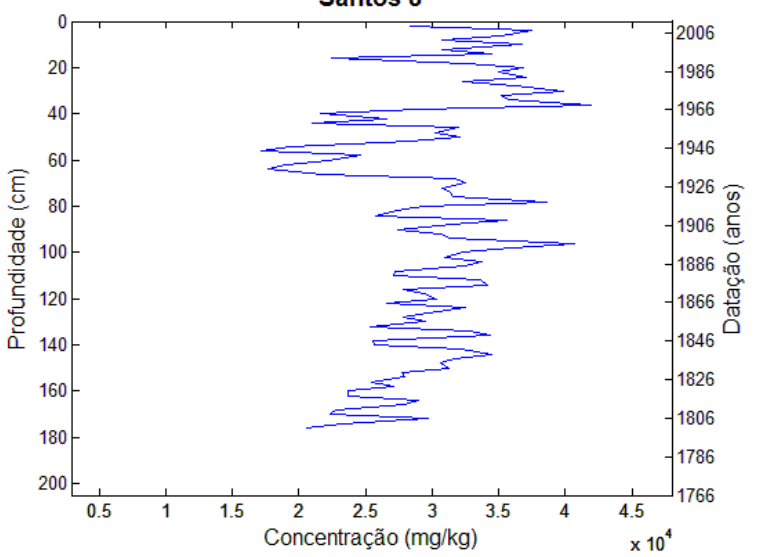

Valores de concentração de $\mathrm{Al}$ ( $\mathrm{mg} / \mathrm{kg}$ ) para os testemunhos estudados.(Continuação) 


\section{Ferro (Fe)}
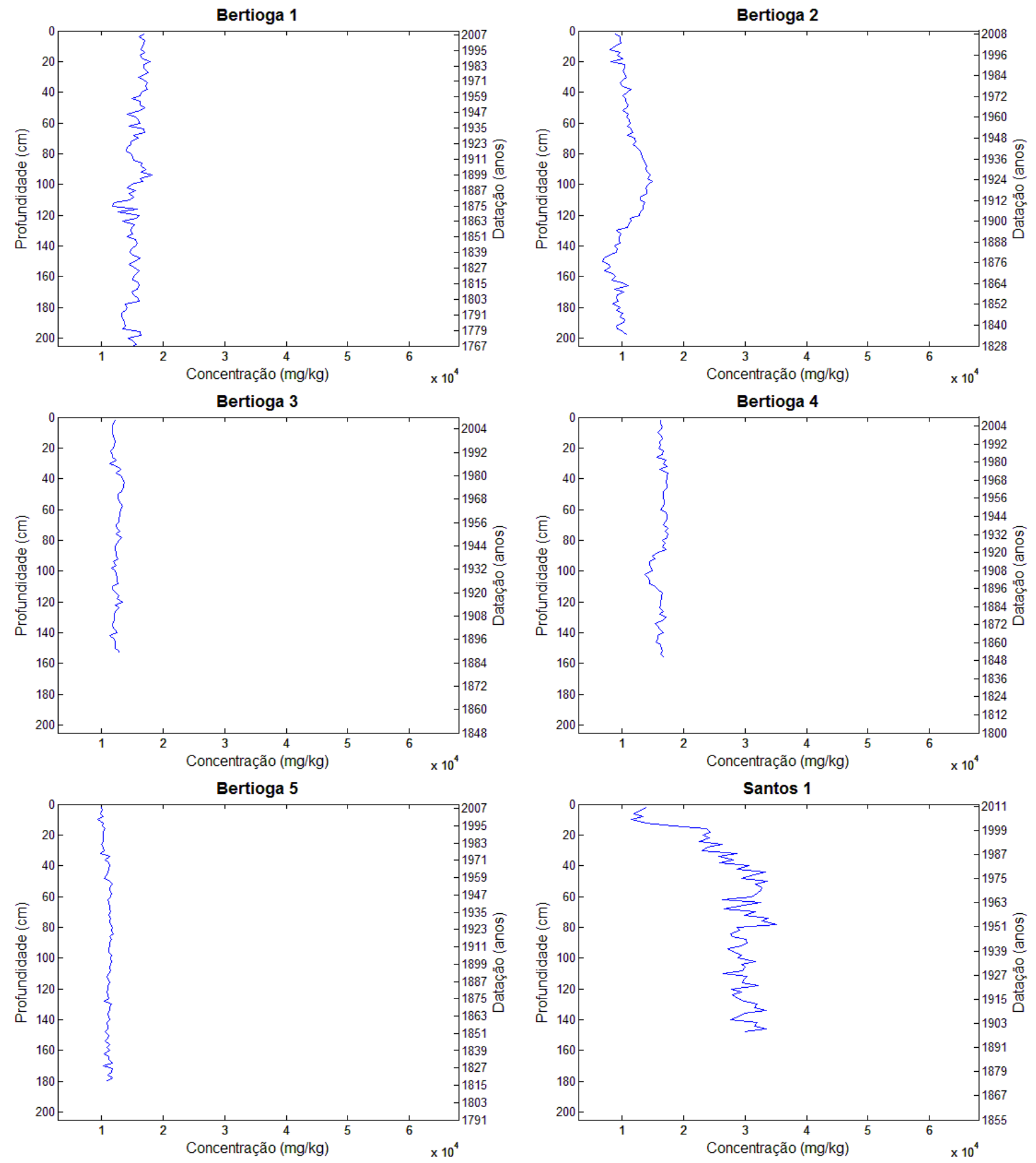

Valores de concentração de Fe ( $\mathrm{mg} / \mathrm{kg}$ ) para os testemunhos estudados. 

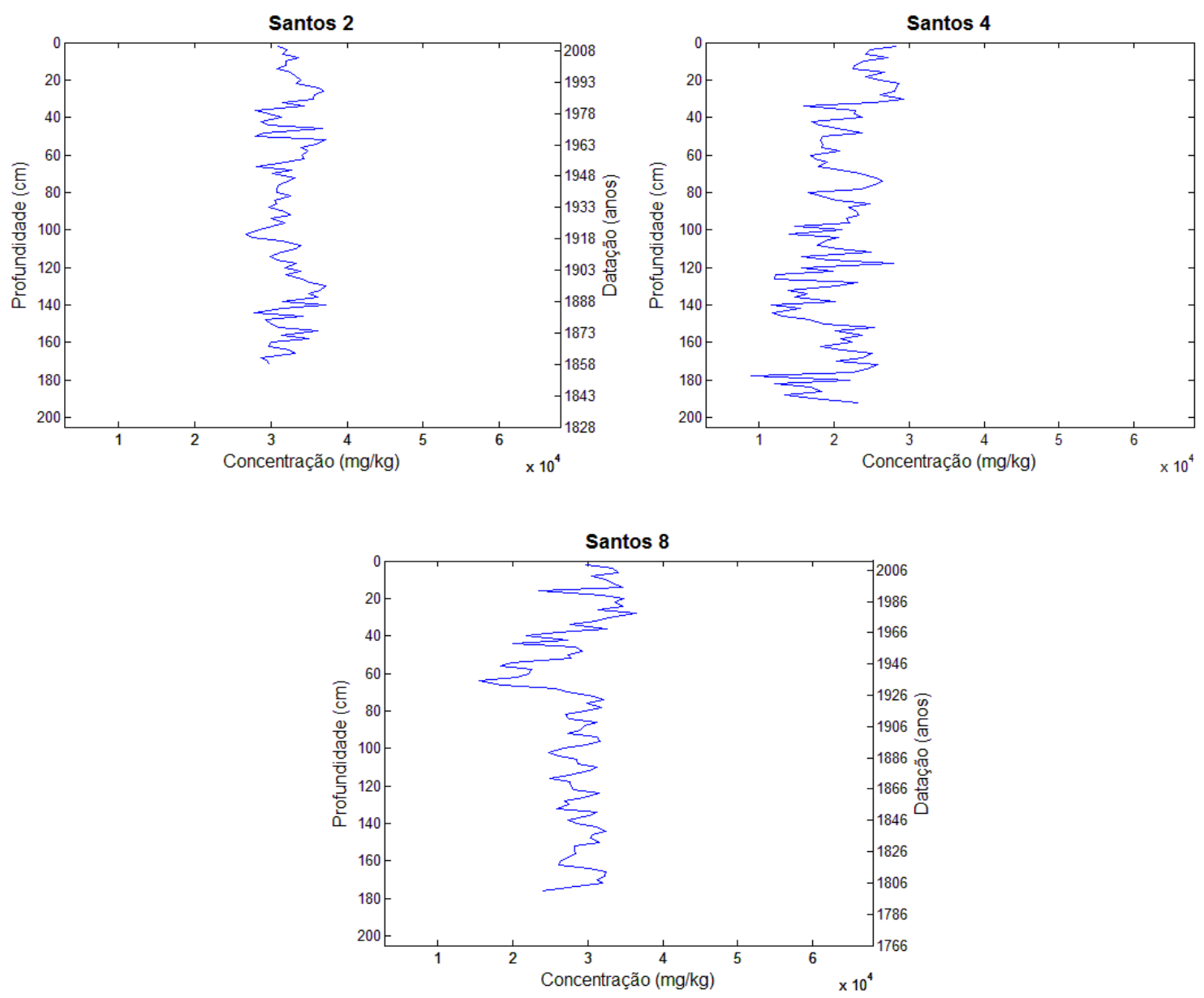

Valores de concentração de $\mathrm{Fe}$ ( $\mathrm{mg} / \mathrm{kg}$ ) para os testemunhos estudados.(Continuação) 


\section{Manganês (Mn)}
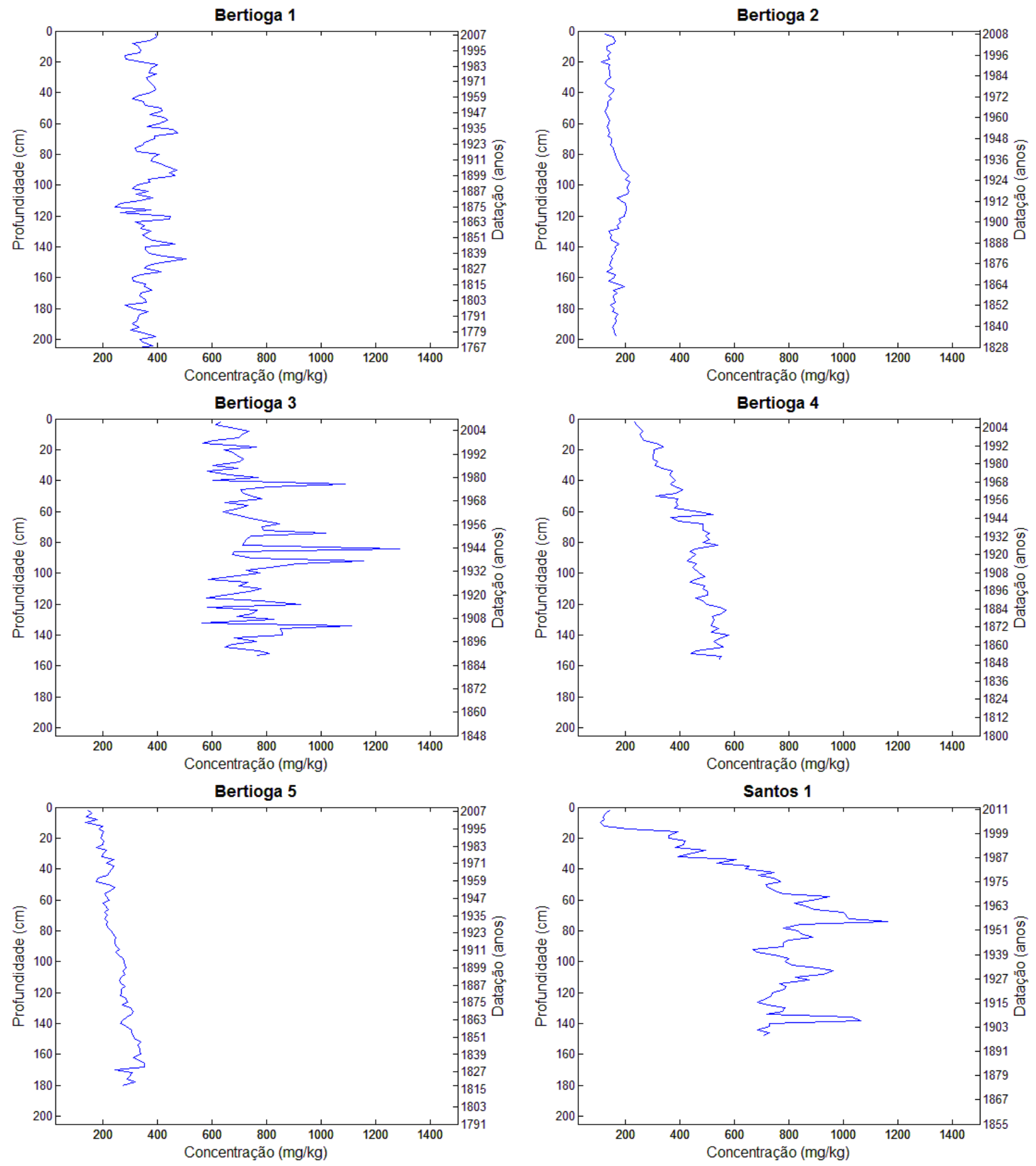

Valores de concentração de Mn (mg/kg) para os testemunhos estudados. 

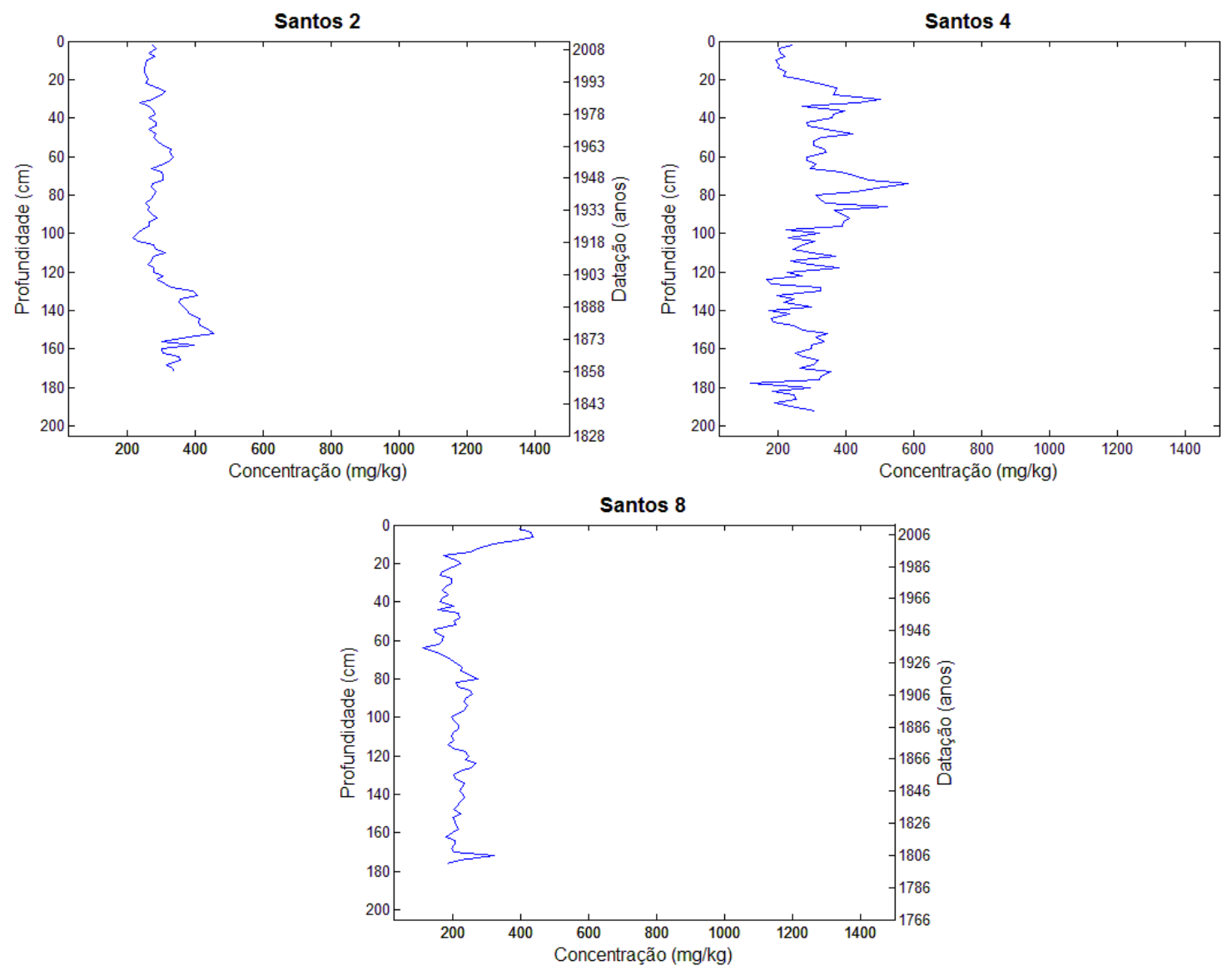

Valores de concentração de Mn ( $\mathrm{mg} / \mathrm{kg}$ ) para os testemunhos estudados.(Continuação) 


\section{Escândio (Sc)}
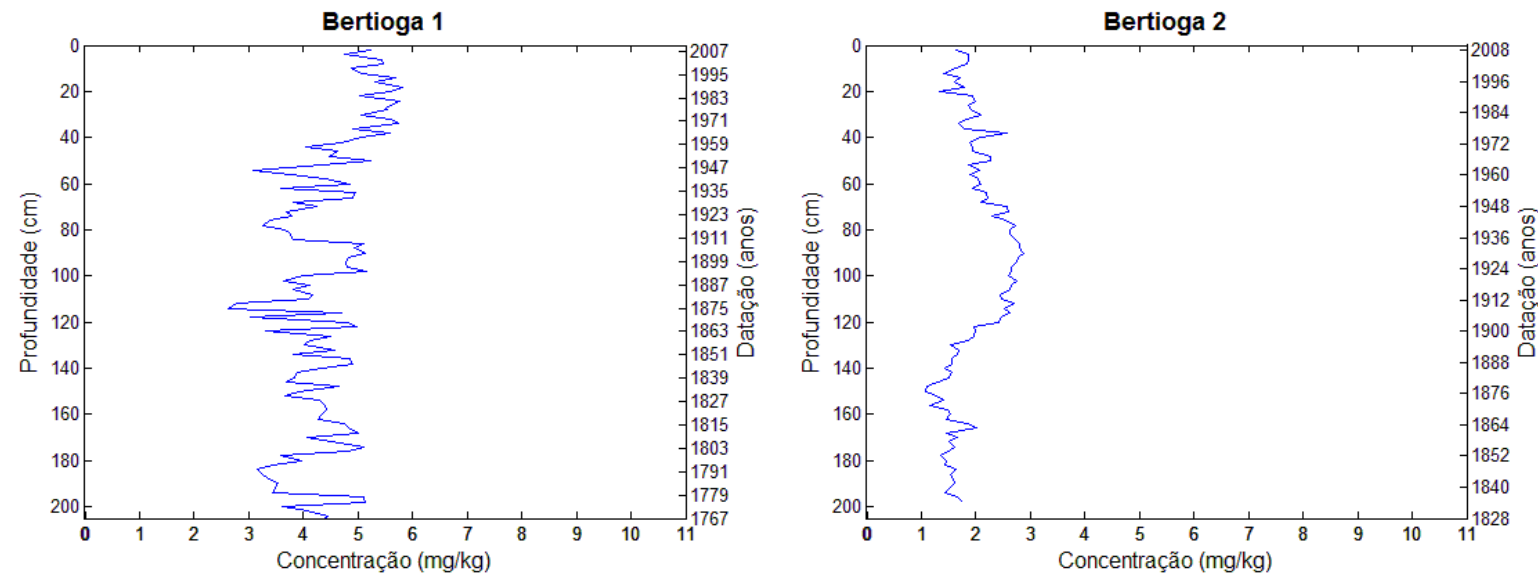

Bertioga 3
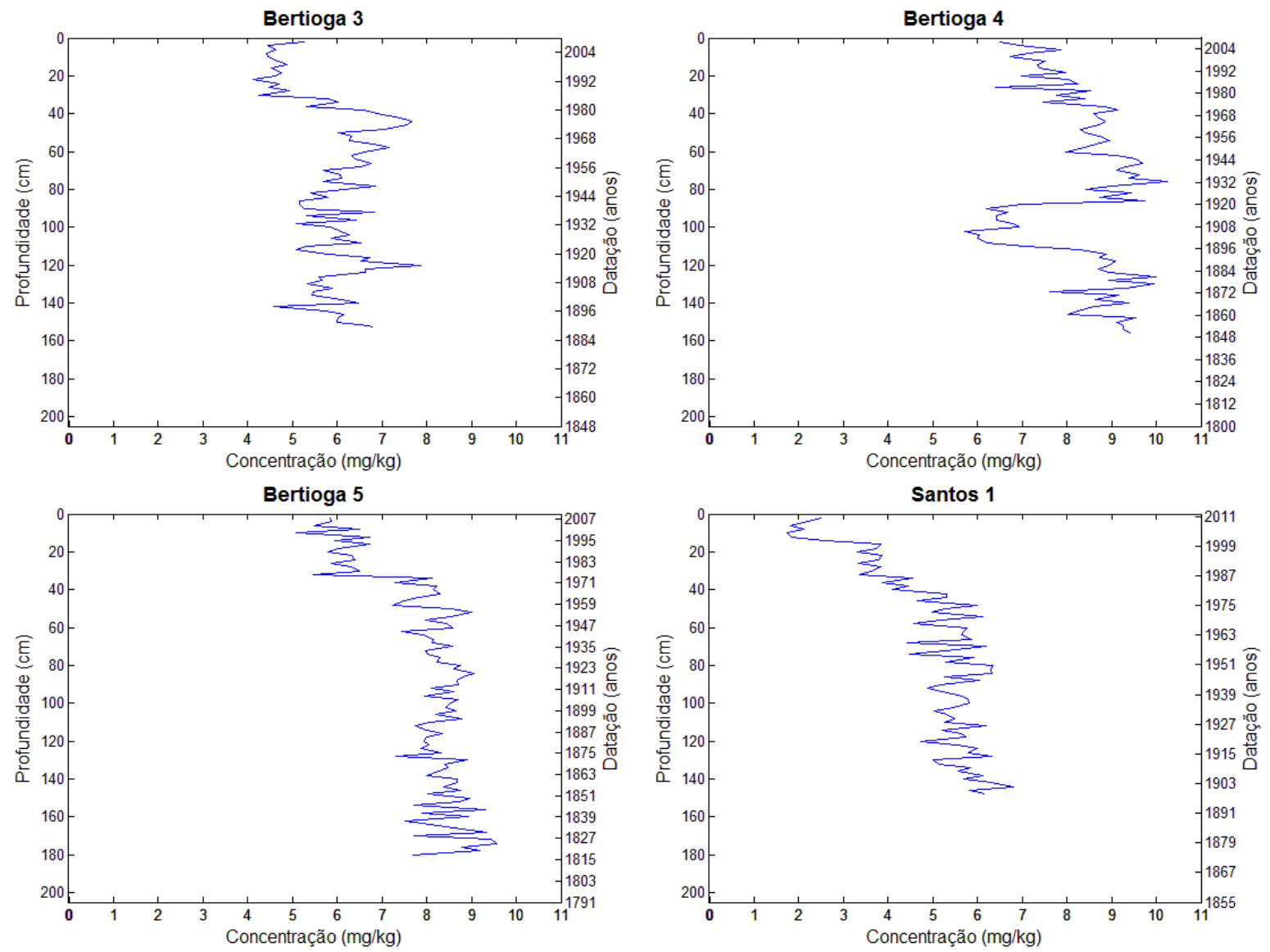

Valores de concentração de $S c(\mathrm{mg} / \mathrm{kg})$ para os testemunhos estudados. 

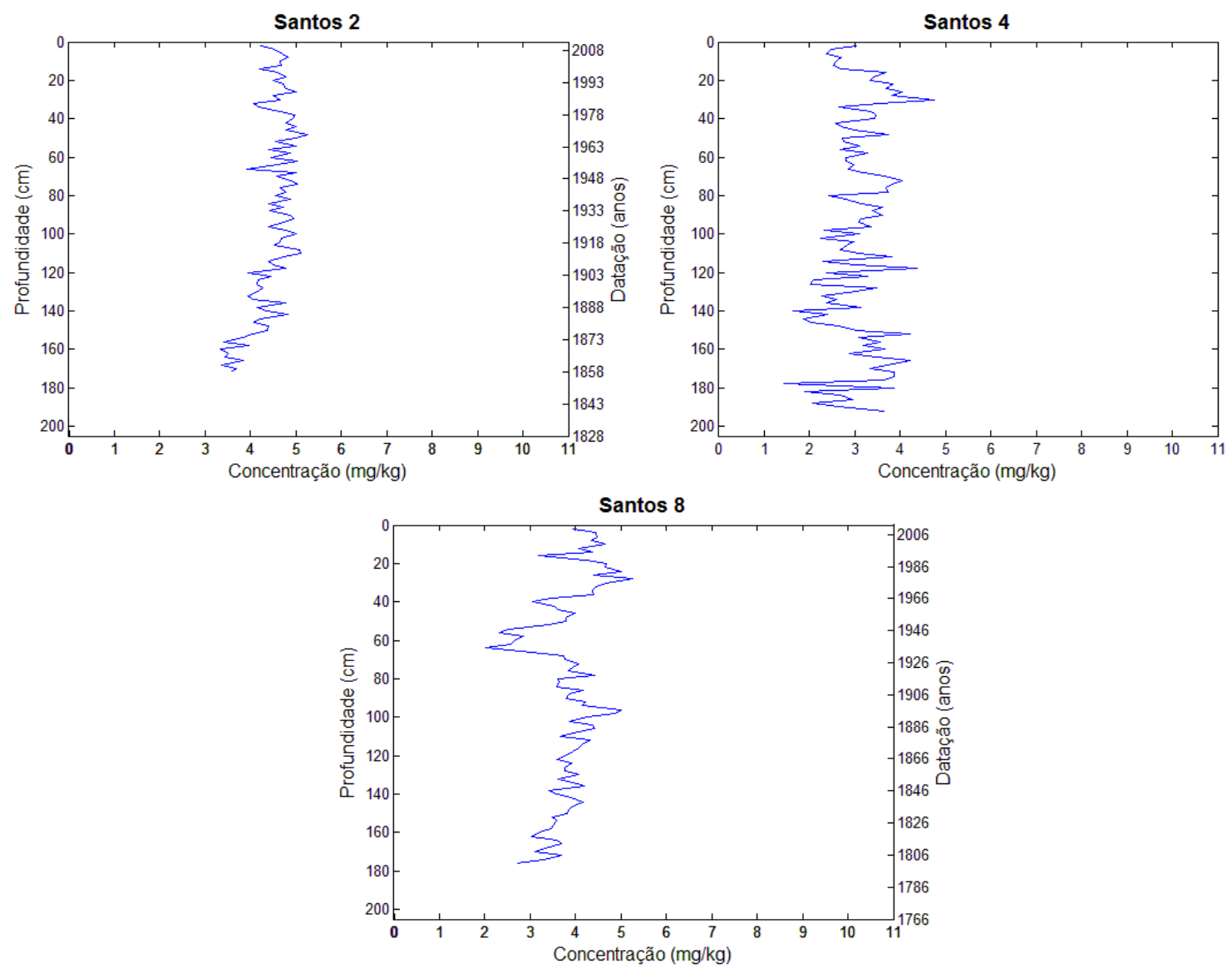

Valores de concentração de Sc ( $\mathrm{mg} / \mathrm{kg}$ ) para os testemunhos estudados. (Continuação) 
Vanádio (V)
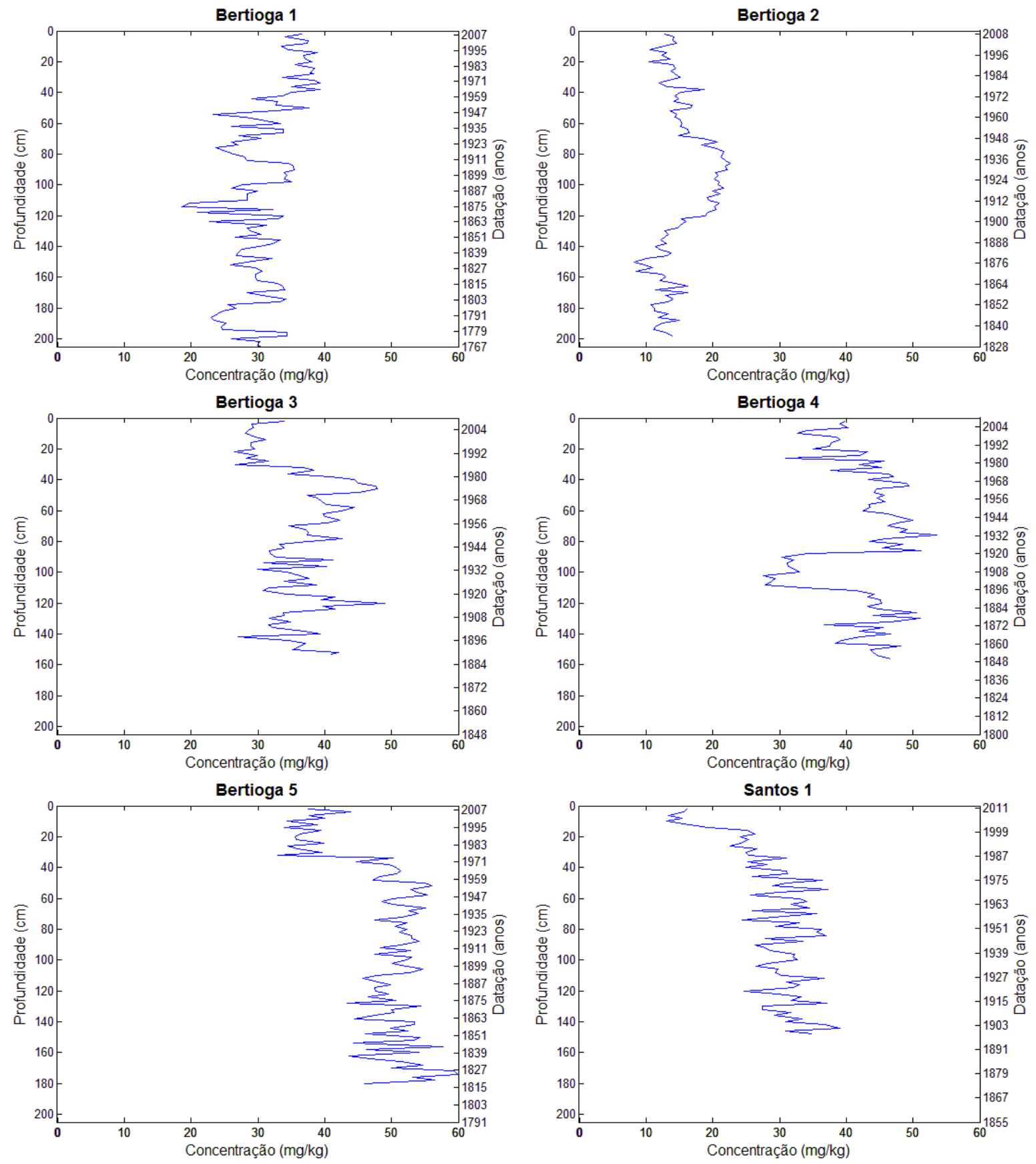

Valores de concentração de $V(\mathrm{mg} / \mathrm{kg})$ para os testemunhos estudados. 

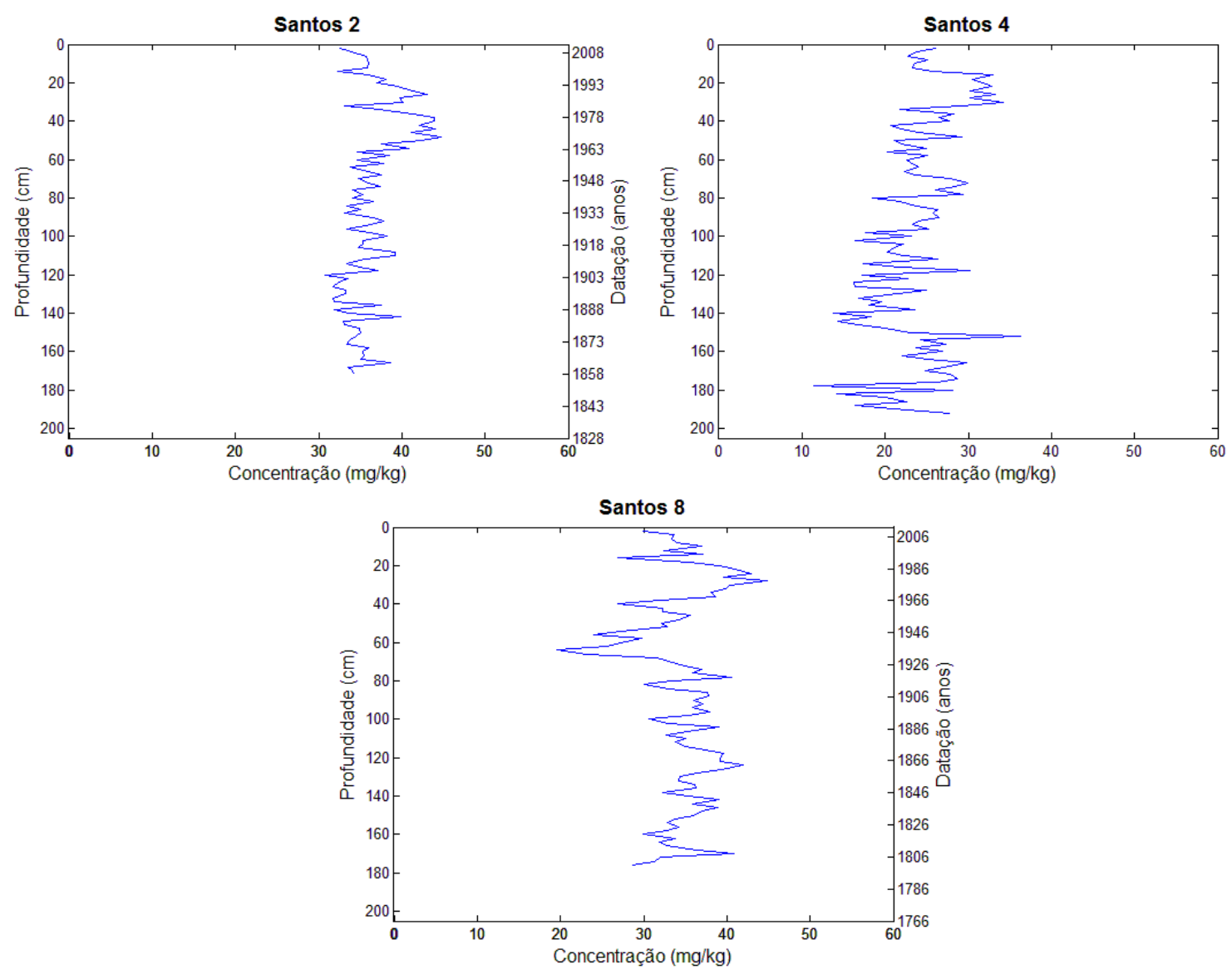

Valores de concentração de $V(\mathrm{mg} / \mathrm{kg})$ para os testemunhos estudados. 


\section{ANEXO 2}

PERFIS DE FATOR DE ENRIQUECIMENTO 


\section{Alumínio (Al)}
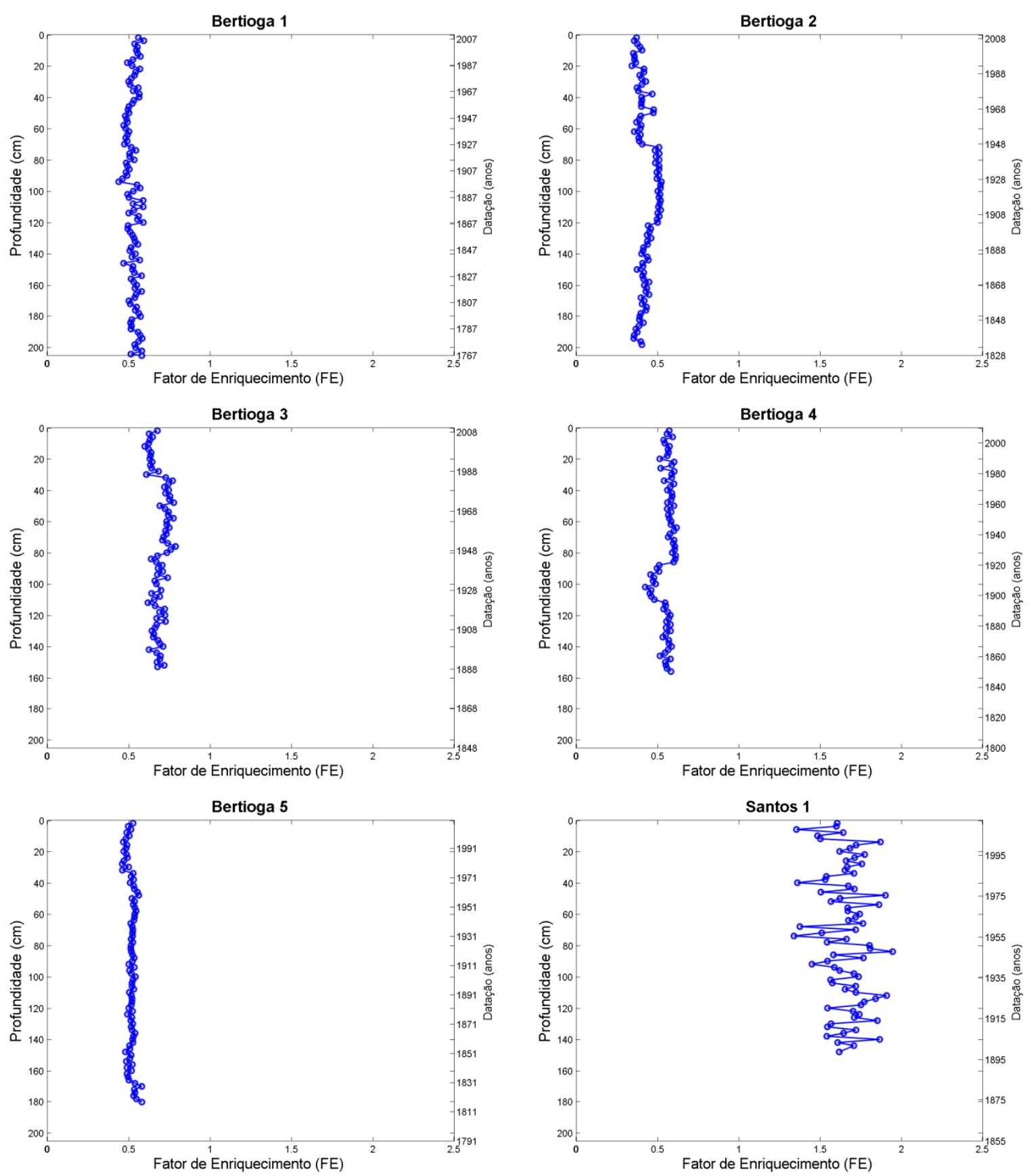

Valores de fator de enriquecimento para Al nos testemunhos estudados. 

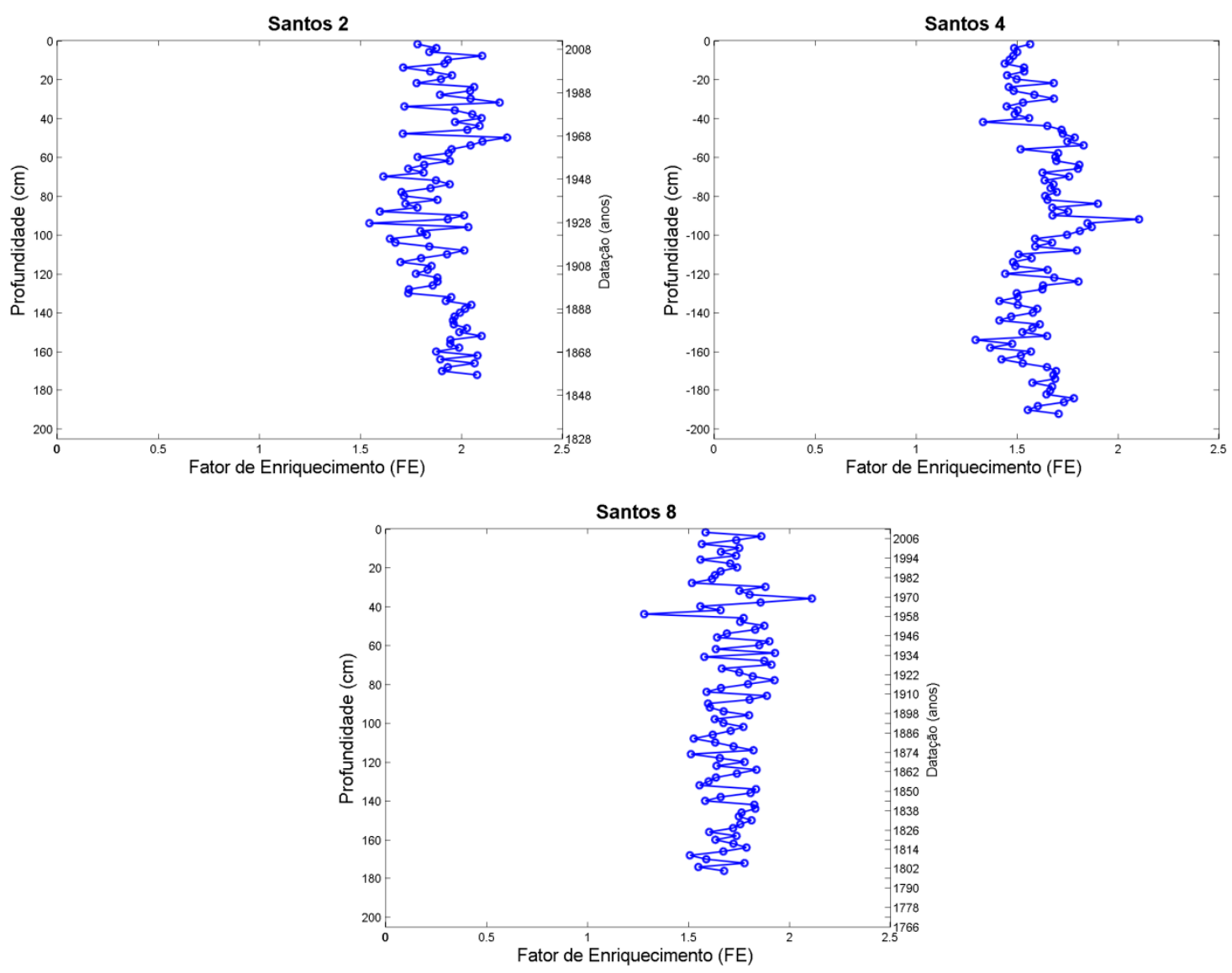

Valores de fator de enriquecimento para Al nos testemunhos estudados. (Continuação) 


\section{Arsênio (As)}
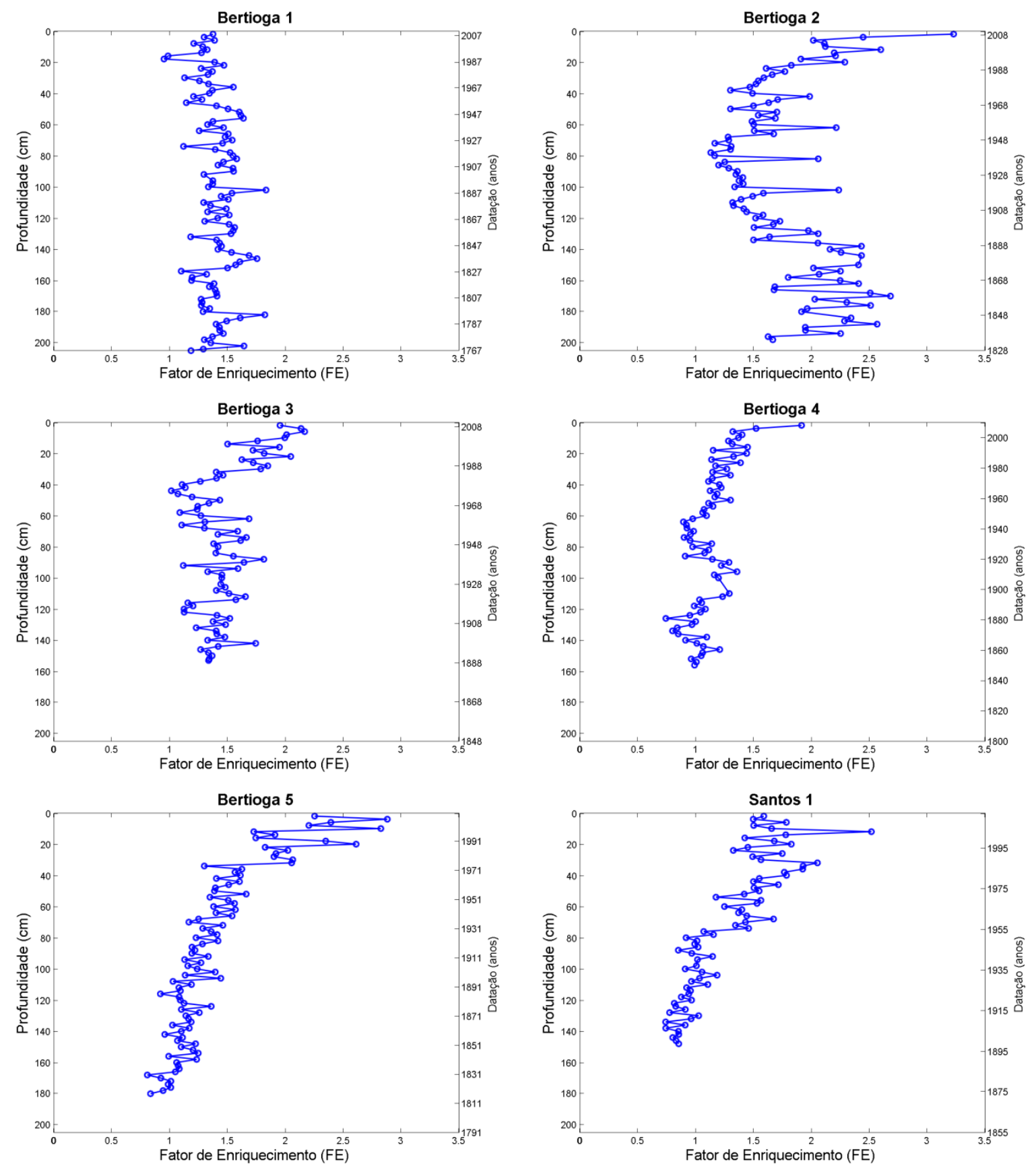

Valores de fator de enriquecimento para As nos testemunhos estudados. 

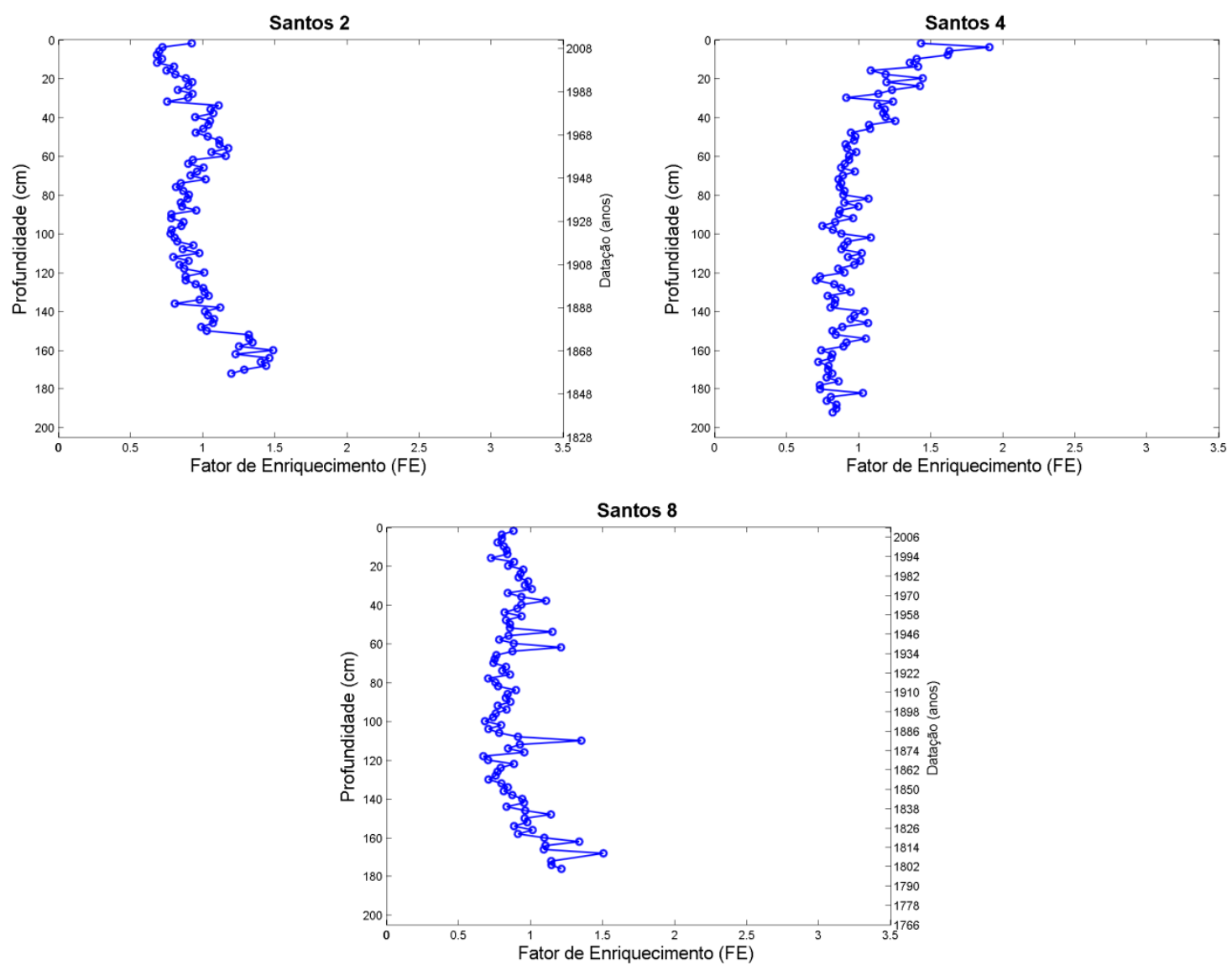

Valores de fator de enriquecimento para As nos testemunhos estudados. (Continuação) 


\section{Cromo (Cr)}
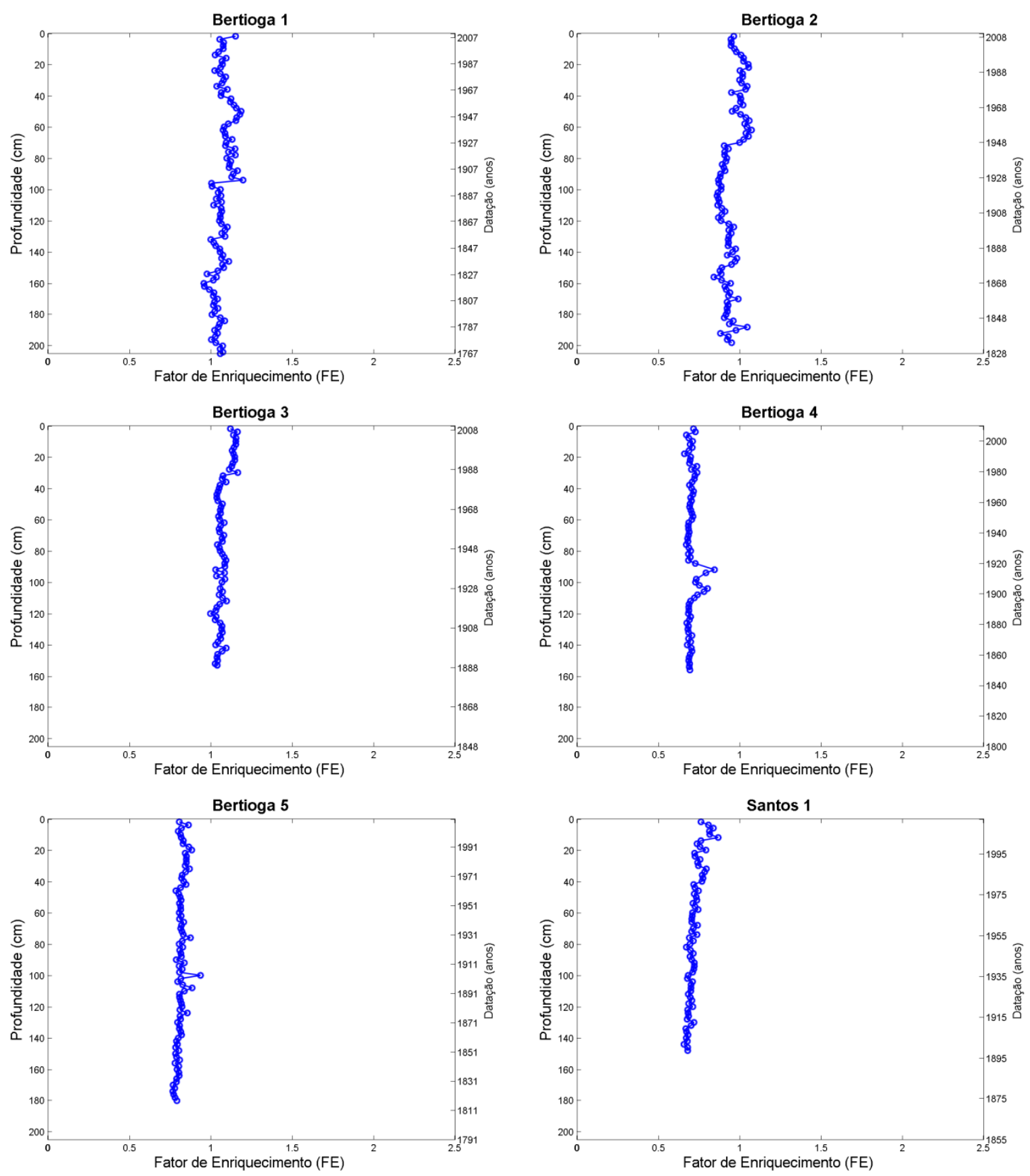

Valores de fator de enriquecimento para Cr nos testemunhos estudados. 

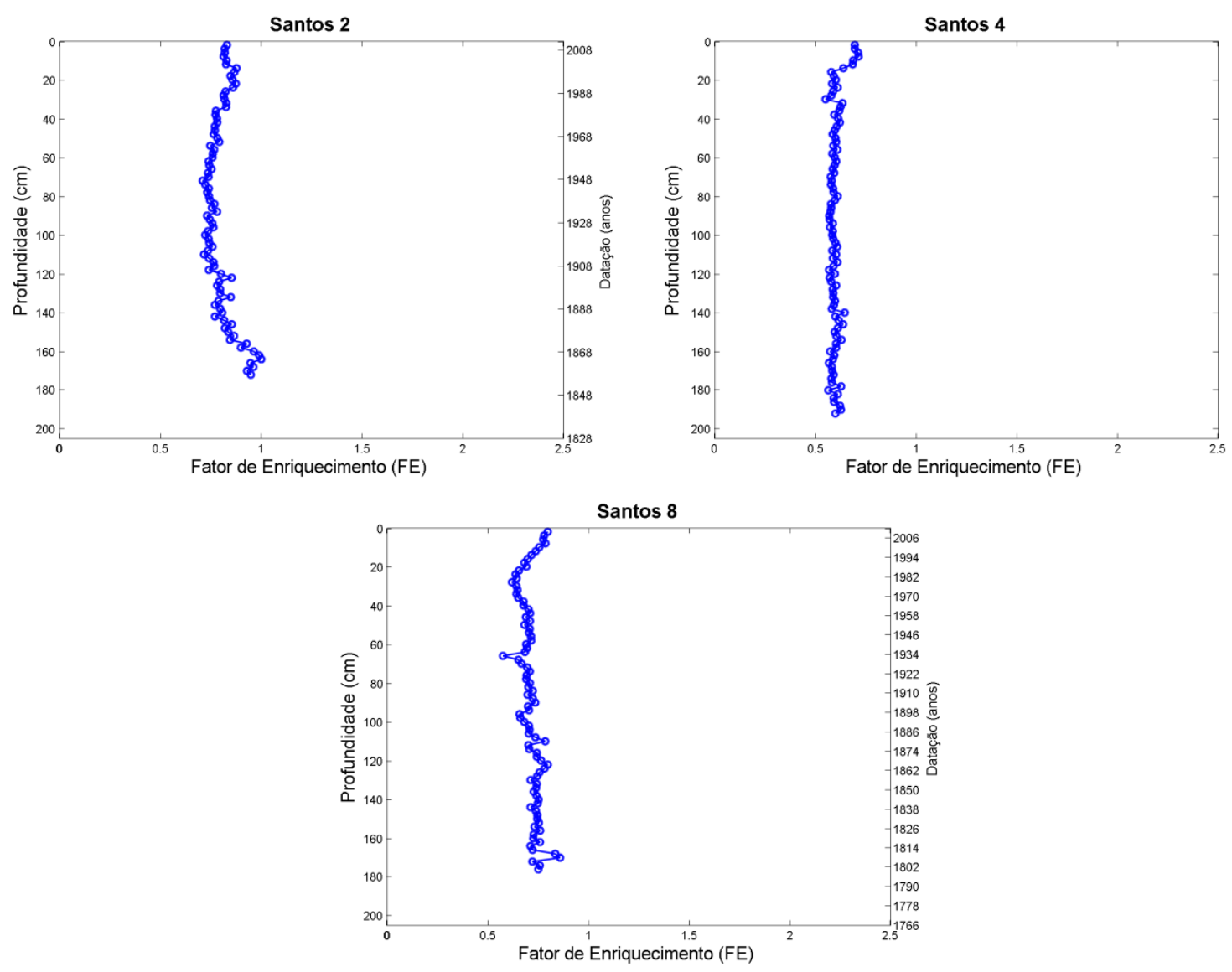

Valores de fator de enriquecimento para Cr nos testemunhos estudados.(Continuação) 


\section{Cobre (Cu)}
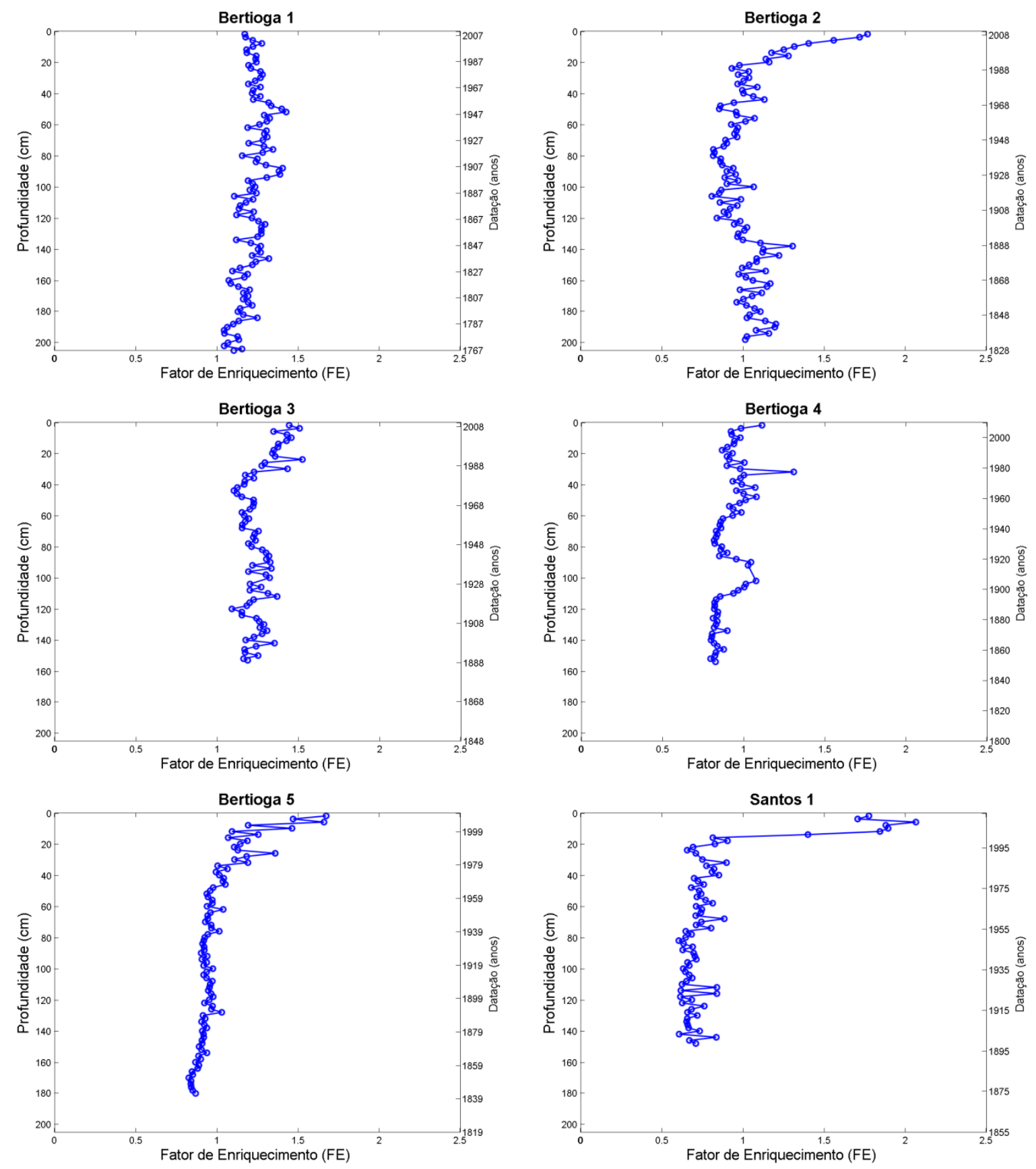

Valores de fator de enriquecimento para Cu nos testemunhos estudados. 

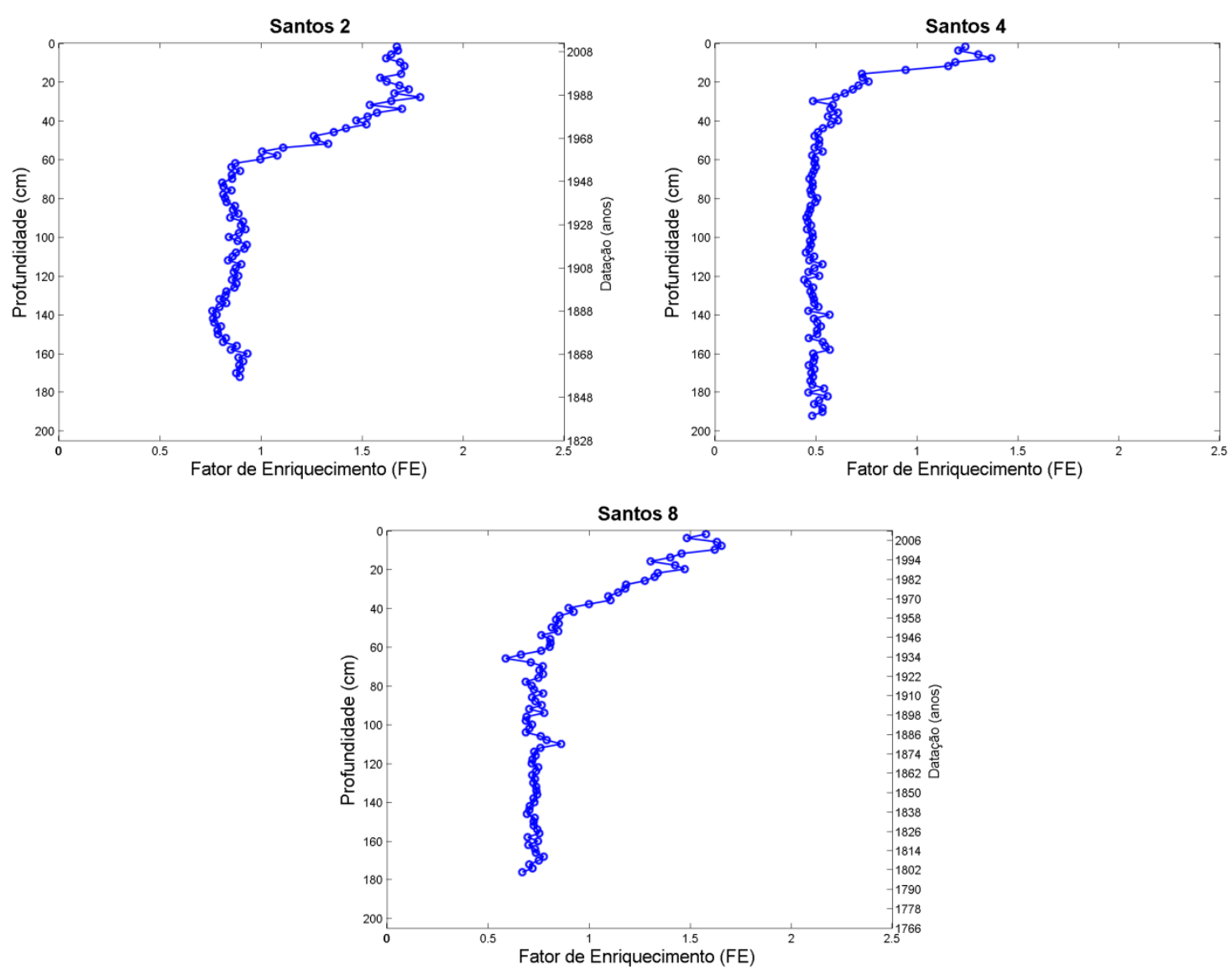

Valores de fator de enriquecimento para Cu nos testemunhos estudados. (Continuação) 


\section{Mercúrio (Hg)}
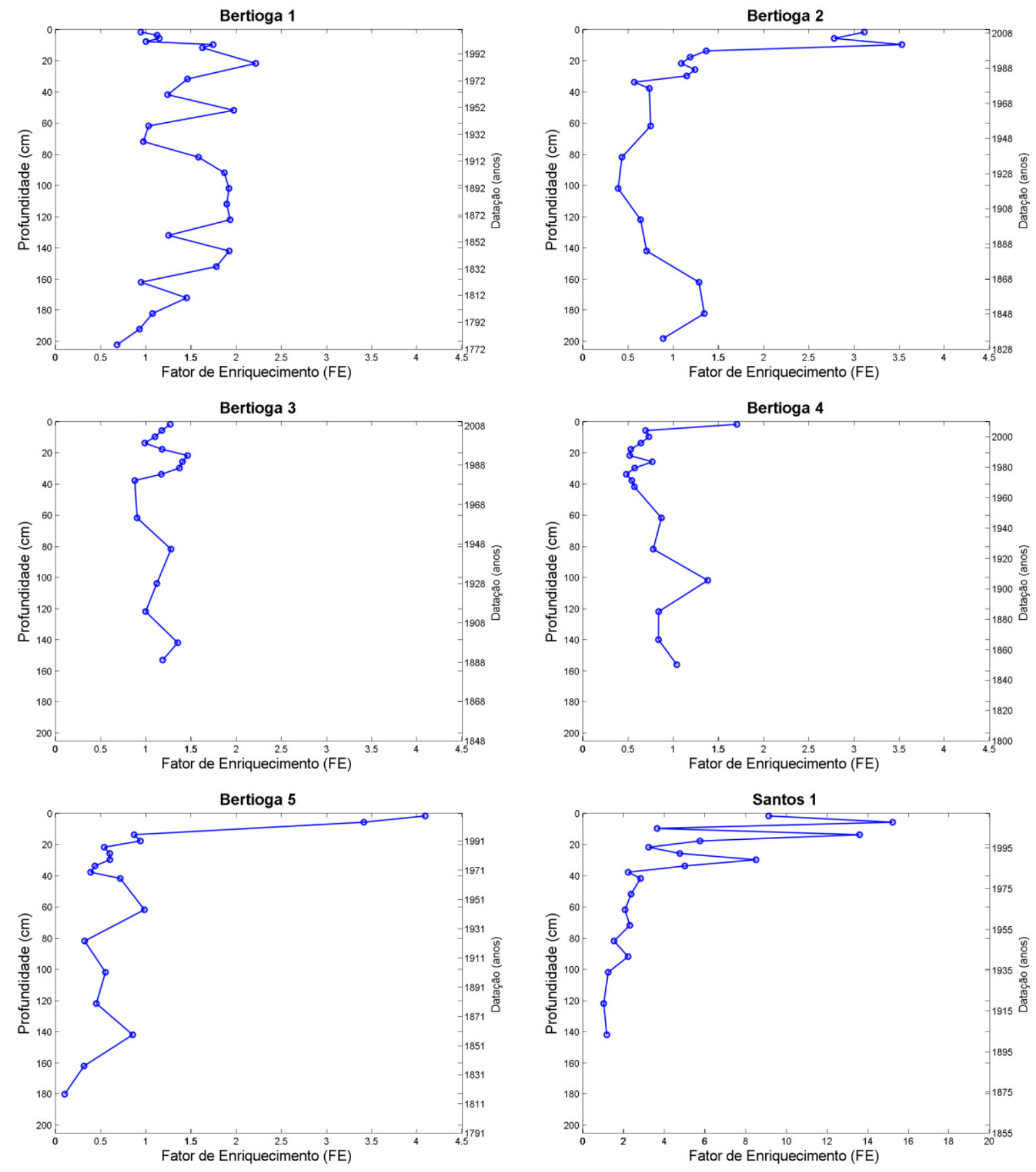

Valores de fator de enriquecimento para Hg nos testemunhos estudados. 

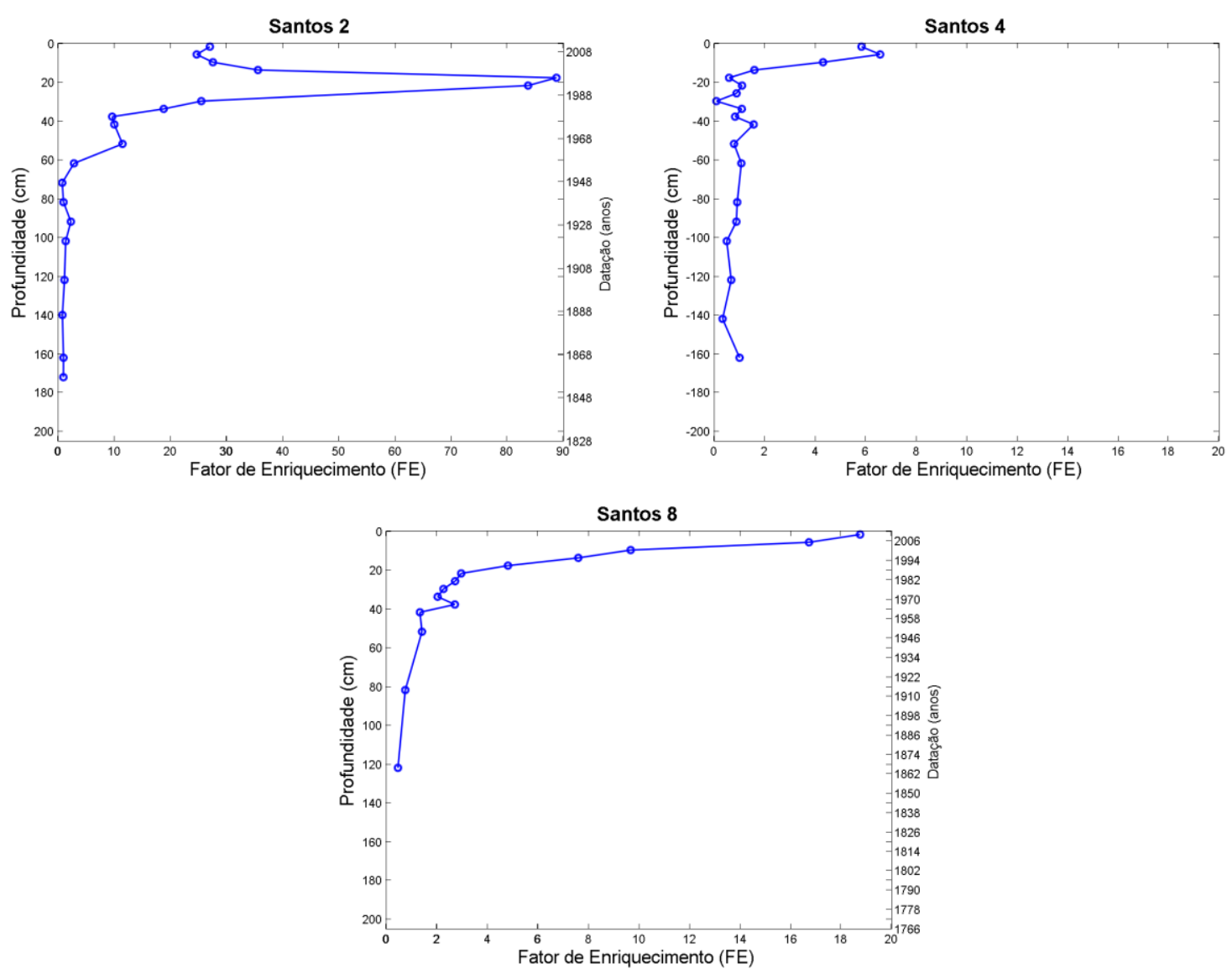

Valores de fator de enriquecimento para $\mathrm{Hg}$ nos testemunhos estudados. (Continuação) 


\section{Níquel (Ni)}
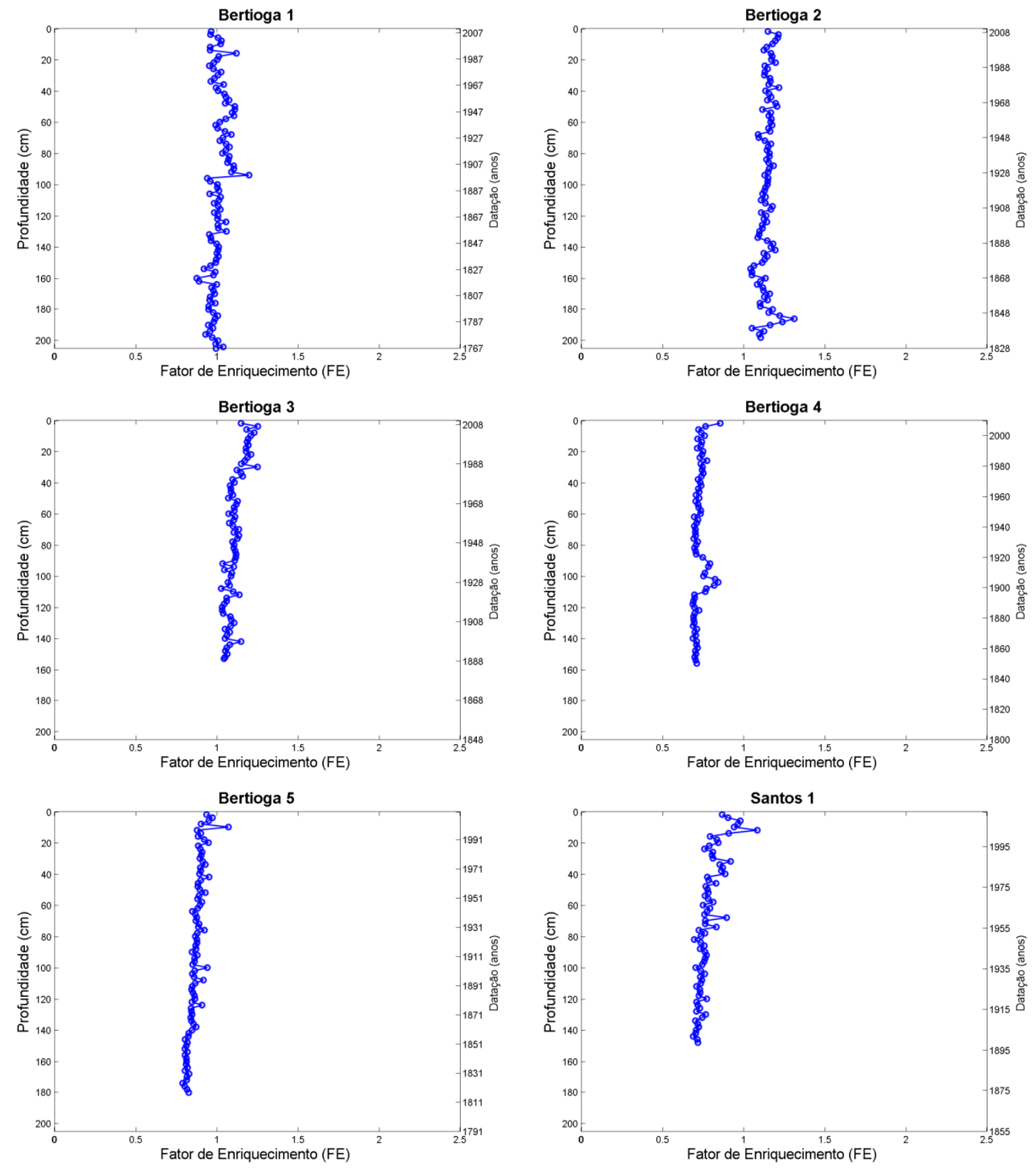

Valores de fator de enriquecimento para Ni nos testemunhos estudados. 

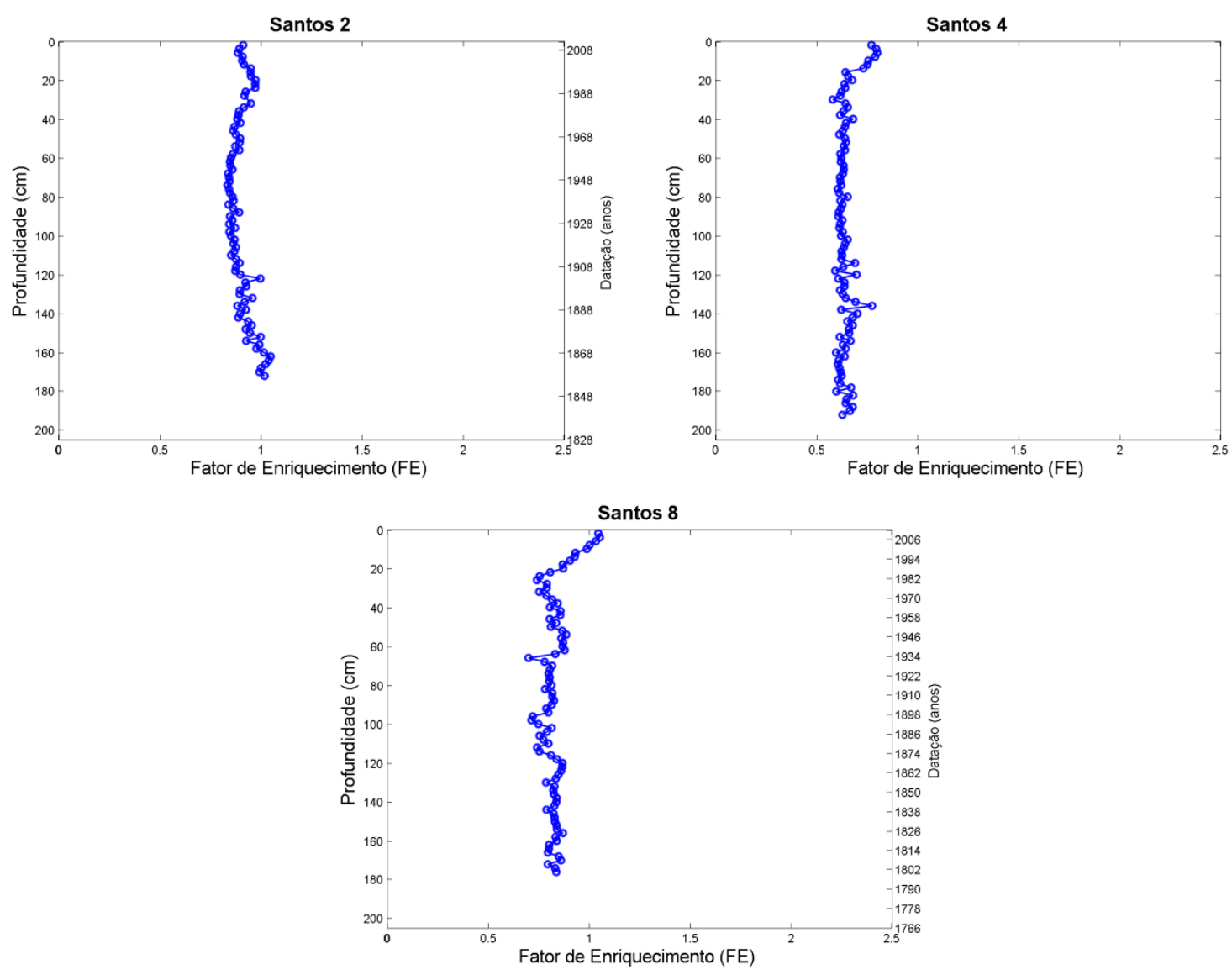

Valores de fator de enriquecimento para Ni nos testemunhos estudados. (Continuação) 


\section{Chumbo (Pb)}
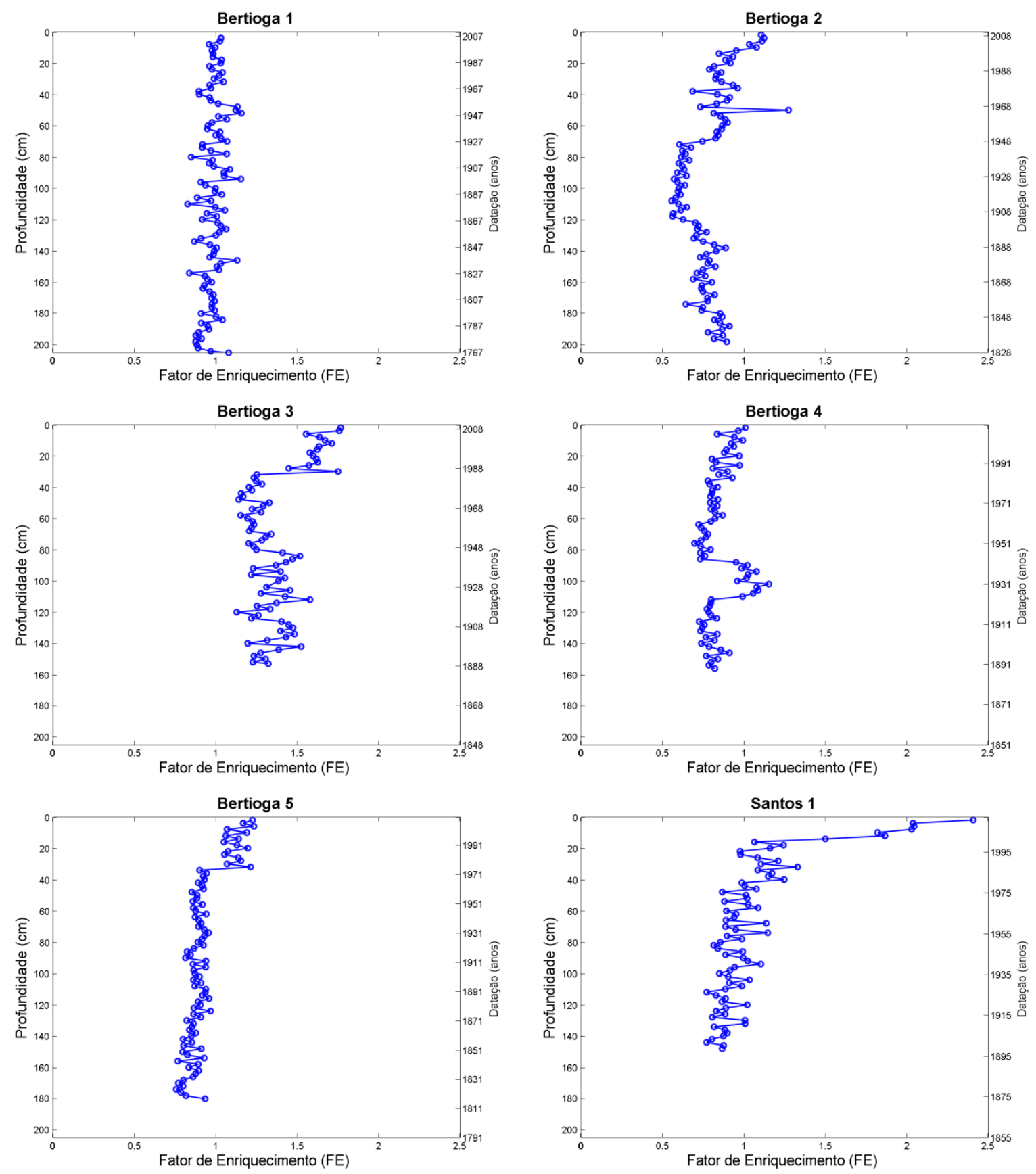

Valores de fator de enriquecimento para Pb nos testemunhos estudados. 

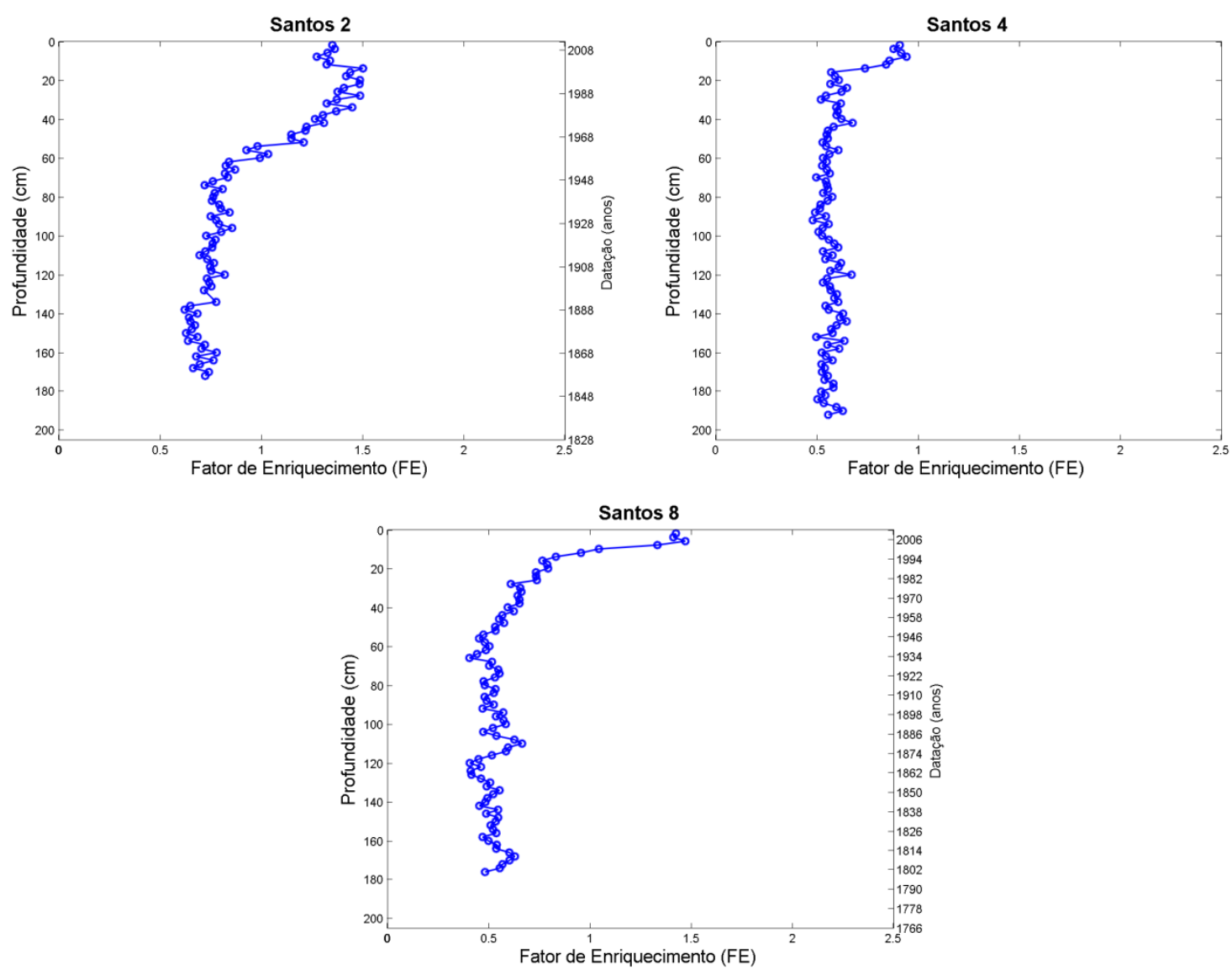

Valores de fator de enriquecimento para Pb nos testemunhos estudados. (Continuação) 


\section{$\operatorname{Zinco}(\mathbf{Z n})$}
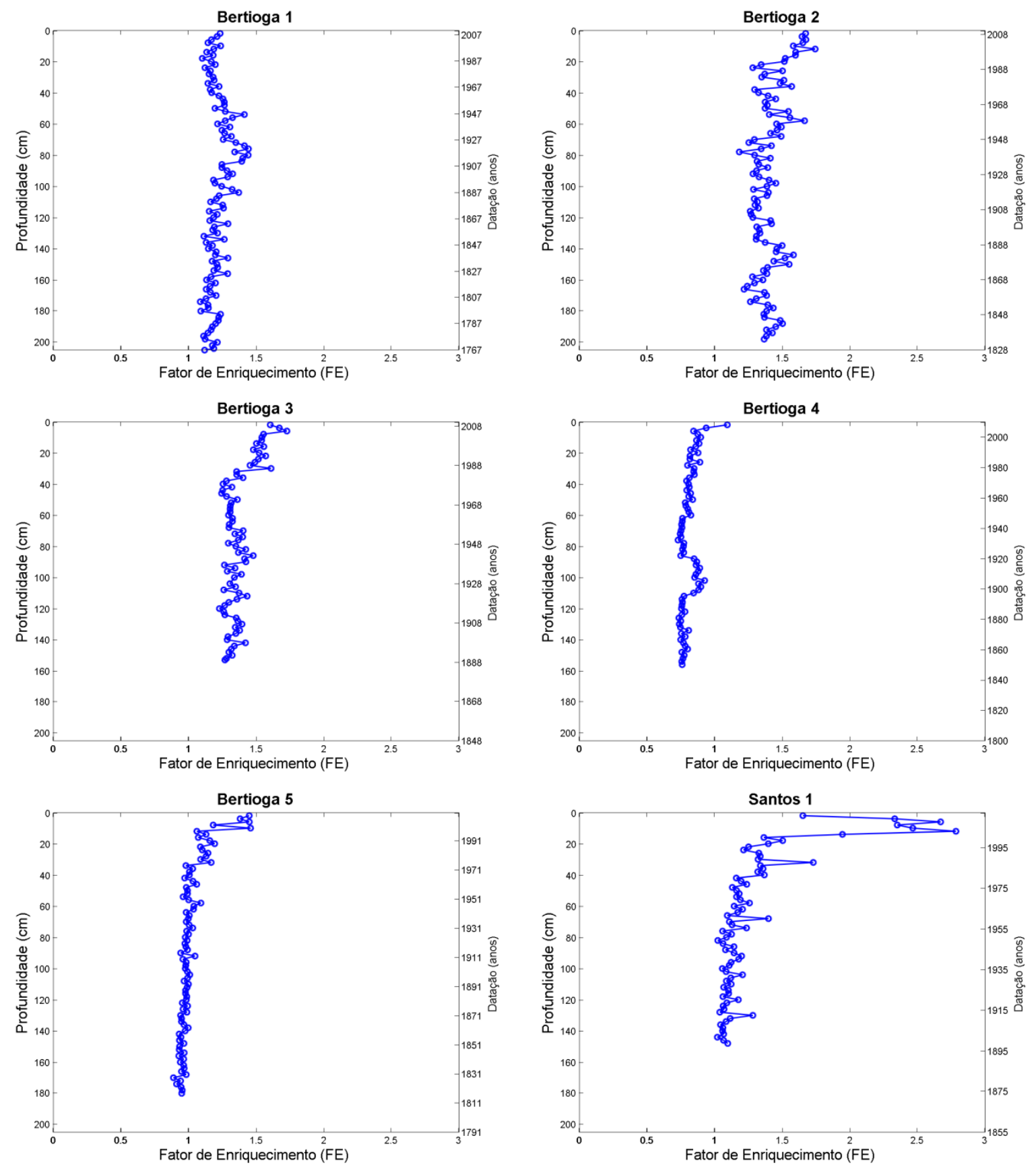

Valores de fator de enriquecimento para Zn nos testemunhos estudados. 

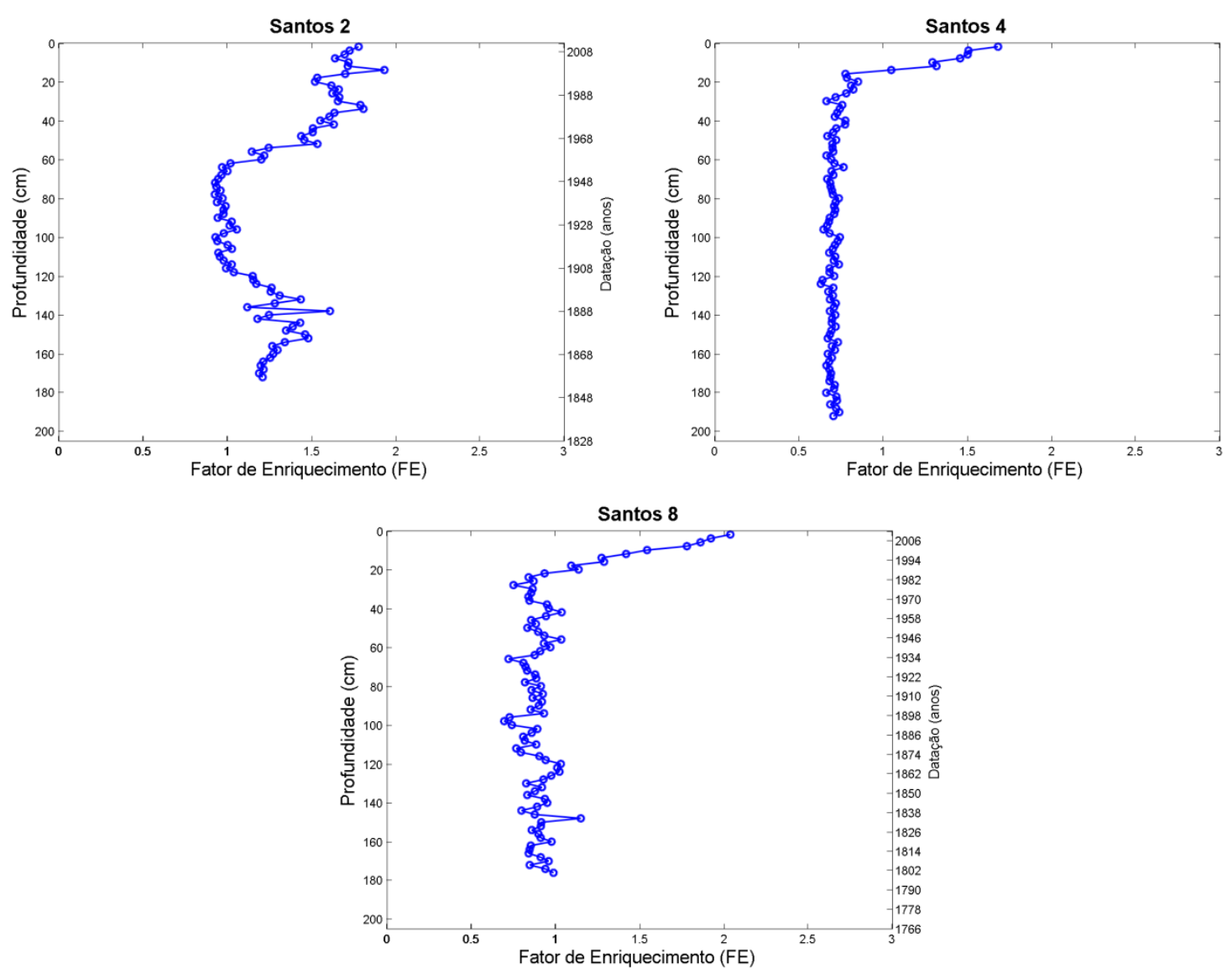

Valores de fator de enriquecimento para Zn nos testemunhos estudados. (Continuação) 


\section{ANEXO 3}

\section{TABELA DE EVENTOS HISTÓRICOS}


Principais eventos históricos relacionados ao desenvolvimento urbano-industrial da Baixada Santista e seu reflexo no teor de testemunhos (Adaptado de Fukumoto, 2007).

\begin{tabular}{|c|c|c|c|c|c|c|c|}
\hline \multirow[b]{2}{*}{ Ano } & \multirow[b]{2}{*}{ Evento histórico } & \multicolumn{3}{|c|}{ Fukumoto (2007) } & \multicolumn{3}{|c|}{ Presente trabalho } \\
\hline & & $\begin{array}{c}\text { Largo de Santa } \\
\text { Rita }\end{array}$ & Rio Casqueiro & Largo do Canéu & Santos 1 & Santos 2 & Santos 8 \\
\hline $\begin{array}{l}1991 \\
a \\
2000\end{array}$ & $\begin{array}{l}\text { - Melhoria da qualidade das } \\
\text { águas e recuperação dos } \\
\text { manguezais }\end{array}$ & $\begin{array}{l}\text { Aumento dos } \\
\text { teores de } \mathrm{Cu}, \\
\mathrm{Cr} \text { e } \mathrm{Pb} \text { até } \\
\text { 1996, seguido } \\
\text { do declínio } \\
\text { dos valores. }\end{array}$ & $\begin{array}{l}\text { Aumento dos } \\
\text { teores de } \\
\text { metais até } \\
\text { 1995, quando } \\
\text { se inicia a } \\
\text { diminuição } \\
\text { dos teores. }\end{array}$ & $\begin{array}{l}\text { Aumento dos } \\
\text { teores de } \\
\text { metais até } \\
\text { 1995, quando } \\
\text { se inicia a } \\
\text { diminuição } \\
\text { dos teores. }\end{array}$ & $\begin{array}{l}\text { Enriquecimento } \\
\text { de } \mathrm{Cu}, \mathrm{Hg} \text { e } \mathrm{Zn} \\
\text { até } 2009 \text {, quando } \\
\text { começam a } \\
\text { diminuir. } \\
\text { Aumento de } \mathrm{FE} \\
\text { para } \mathrm{Pb} \text {. }\end{array}$ & $\begin{array}{c}\text { Enriquecimento } \\
\text { de } \mathrm{Hg} \text { até } 1998, \\
\text { e de } \mathrm{Pb} \text { até } 2001, \\
\text { quando passam a } \\
\text { diminuir. } \\
\text { Aumento de FE } \\
\text { para } \mathrm{Zn} .\end{array}$ & $\begin{array}{l}\text { Enriquecimento } \\
\text { de todos os } \\
\text { metais }\end{array}$ \\
\hline $\begin{array}{c}1981 \\
a \\
1990\end{array}$ & $\begin{array}{l}\text { - Desvalorização imobiliária e } \\
\text { declínio do turismo } \\
\text { - Tragédia de Vila Socó } \\
\text { - Implantação de medidas de } \\
\text { preservação do Estuário } \\
\text { Santista }\end{array}$ & $\begin{array}{l}\text { Diminuição dos } \\
\text { teores de } \mathrm{Cr}, \mathrm{Cu} \\
\text { e } \mathrm{Pb} \text { até } 1993, \\
\text { seguido de } \\
\text { aumento dos } \\
\text { teores. Aumento } \\
\text { do teor de } \mathrm{Zn} \text {. }\end{array}$ & $\begin{array}{l}\text { Aumento dos } \\
\text { teores de } \mathrm{Cu} \text {, } \\
\mathrm{Cr}, \mathrm{Pb} \text { e } \mathrm{Zn} \text {. }\end{array}$ & $\begin{array}{l}\text { Aumento } \\
\text { acentuado do } \\
\text { teor de } \mathrm{Zn} \text {. } \\
\text { Aumento dos } \\
\text { teores de } \\
\mathrm{Cu}, \mathrm{Pb} \text { e } \mathrm{Fe} \text {. }\end{array}$ & $\begin{array}{l}\text { Enquecimento de } \\
\mathrm{As}, \mathrm{Hg}, \mathrm{Pb} \text { e } \mathrm{Zn}\end{array}$ & $\begin{array}{l}\text { Enriquecimento } \\
\text { de } \mathrm{Cu}, \mathrm{Hg}, \mathrm{Pb} \text { e } \\
\text { Zn. }\end{array}$ & $\begin{array}{l}\text { Enriquecimento } \\
\text { de todos os } \\
\text { metais }\end{array}$ \\
\hline $\begin{array}{c}1971 \\
a \\
1980\end{array}$ & $\begin{array}{l}\text { - Auge da Expansão do Polo } \\
\text { Industrial de Cubatão } \\
\text { - Intensificação da ocupação } \\
\text { populacional do Rio Casqueiro } \\
\text { - Implantação do Lixão do } \\
\text { Alemoa } \\
\text { - Inauguração da Rodovia dos } \\
\text { Imigrantes } \\
\text { - Instalação de indústrias de } \\
\text { fertilizantes (Manah, } \\
\text { Ultrafértil, IAP) } \\
\text {-Expansão imobiliária e ocupa- } \\
\text { cional da Baixada Santista } \\
\text { - Início da dragagem do Canal } \\
\text { de Piaçanguera }\end{array}$ & $\begin{array}{l}\text { Diminuição } \\
\text { dos teores de } \\
\mathrm{Cr}, \mathrm{Cu} \text { e } \mathrm{Pb} \text {. } \\
\text { Aumento do } \\
\text { teor de } \mathrm{Zn} \text {. }\end{array}$ & $\begin{array}{l}\text { Aumento dos } \\
\text { teores de } \mathrm{Cu} \text {, } \\
\mathrm{Cr}, \mathrm{Pb} \text { e } \mathrm{Zn} \text {. }\end{array}$ & $\begin{array}{l}\text { Teores de metais } \\
\text { próximos aos } \\
\text { valores de } \\
\text { background. }\end{array}$ & $\begin{array}{l}\text { Enriquecimento } \\
\text { de As e Hg. } \\
\text { Teores dos } \\
\text { demais metais } \\
\text { próximos aos } \\
\text { valores de } \\
\text { background. }\end{array}$ & $\begin{array}{l}\text { Enriquecimento } \\
\text { de } \mathrm{Cu}, \mathrm{Hg}, \mathrm{Pb} \text { e } \\
\text { Zn. }\end{array}$ & $\begin{array}{c}\text { Enriquecimento } \\
\text { de } \mathrm{Cu}, \mathrm{Hg}, \mathrm{Pb} \text { e } \\
\mathrm{Zn} .\end{array}$ \\
\hline
\end{tabular}


Principais eventos históricos relacionados ao desenvolvimento urbano-industrial da Baixada Santista e seu reflexo no teor de testemunhos (Adaptado de Fukumoto, 2007). (Continuação)

\begin{tabular}{|c|c|c|c|c|c|c|c|}
\hline \multirow[b]{2}{*}{ Ano } & \multirow[b]{2}{*}{ Evento histórico } & \multicolumn{3}{|c|}{ Fukumoto, 2007} & \multicolumn{3}{|c|}{ Presente trabalho } \\
\hline & & $\begin{array}{c}\text { Largo de Santa } \\
\text { Rita }\end{array}$ & Rio Casqueiro & Largo do Canéu & Santos 1 & Santos 2 & Santos 8 \\
\hline $\begin{array}{c}1961 \\
\mathrm{a} \\
1970\end{array}$ & $\begin{array}{l}\text { - Início da ocupação } \\
\text { populacional do Rio Casqueiro } \\
\text { (Vila dos Pescadores) } \\
\text { - Inauguração da Cosipa } \\
\text { - Abertura do Canal de } \\
\text { Piaçagüera }\end{array}$ & $\begin{array}{l}\text { Aumento dos } \\
\text { teores de } \mathrm{Cu}, \mathrm{Cr} \text {, } \\
\mathrm{Pb} \text { e } \mathrm{Zn} \text {. }\end{array}$ & $\begin{array}{l}\text { Pequeno } \\
\text { aumento dos } \\
\text { teores de } \mathrm{Cu}, \mathrm{Pb} \\
\text { e } \mathrm{Zn}\end{array}$ & $\begin{array}{l}\text { Declínio dos } \\
\text { teores de } \mathrm{Cu}, \mathrm{Cr} \text {, } \\
\mathrm{Fe}, \mathrm{Pb} \text { e } \mathrm{Zn}\end{array}$ & $\begin{array}{l}\text { Enriquecimento } \\
\text { de As e Hg. } \\
\text { Teores dos } \\
\text { demais metais } \\
\text { próximos aos } \\
\text { valores de } \\
\text { background. }\end{array}$ & $\begin{array}{l}\text { Enriquecimento } \\
\text { de } \mathrm{Cu}, \mathrm{Hg}, \mathrm{Pb} \text { e } \\
\mathrm{Zn} .\end{array}$ & $\begin{array}{l}\text { Enriquecimento } \\
\text { de } \mathrm{Cu}, \mathrm{Hg} \text { e } \mathrm{Pb} \text {. }\end{array}$ \\
\hline $\begin{array}{c}1951 \\
\mathrm{a} \\
1960\end{array}$ & $\begin{array}{l}\text { - Início das operações do } \\
\text { oleoduto Santos-São Paulo } \\
\text { - Inauguração do Terminal de } \\
\text { Carga e Descarga de Petróleo } \\
\text { do Alemoa } \\
\text { - Inauguração da Refinaria } \\
\text { Presidente Bernardes } \\
\text { - Criação do Polo Industrial de } \\
\text { Cubatão } \\
\text { - Construção de Usina } \\
\text { hidrelétrica subterrânea } \\
\text { - Criação do Complexo } \\
\text { Siderúrgico }\end{array}$ & $\begin{array}{l}\text { Aumento dos } \\
\text { teores de } \mathrm{Cu}, \mathrm{Cr} \text {, } \\
\quad \mathrm{Pb} \text { e } \mathrm{Zn} \text {. }\end{array}$ & $\begin{array}{l}\text { Aumento dos } \\
\text { teores de Fe } \\
\quad \text { e Al. }\end{array}$ & $\begin{array}{l}\text { Pico dos } \\
\text { valores de } \mathrm{Cr} \text {, } \\
\mathrm{Cu}, \mathrm{Fe}, \mathrm{Pb} \text { e } \\
\mathrm{Zn} .\end{array}$ & $\begin{array}{l}\text { Enriquecimento } \\
\text { de As e Hg. } \\
\text { Teores dos } \\
\text { demais metais } \\
\text { próximos aos } \\
\text { valores de } \\
\text { background. }\end{array}$ & $\begin{array}{c}\text { Pequeno } \\
\text { aumento nos } \\
\text { valores de } \mathrm{FE} \\
\text { para } \mathrm{Cu}, \mathrm{Hg}, \mathrm{Pb} \\
\text { e } \mathrm{Zn}\end{array}$ & $\begin{array}{l}\text { Teores de metais } \\
\text { próximos aos } \\
\text { valores de } \\
\text { background. }\end{array}$ \\
\hline $\begin{array}{l}1941 \\
\mathrm{a} \\
1950\end{array}$ & $\begin{array}{l}\text { - Inauguração da Via Anchieta } \\
\text { - Ampliação do Porto de Santos } \\
\text { - Aumento do fluxo turístico e } \\
\text { de serviços }\end{array}$ & $\begin{array}{l}\text { Teores de metais } \\
\text { próximos aos } \\
\text { valores de } \\
\text { background. }\end{array}$ & $\begin{array}{l}\text { Aumento dos } \\
\text { teores de } \mathrm{Al} \\
\text { Fe. }\end{array}$ & $\begin{array}{l}\text { Aumento dos } \\
\text { teores de } \mathrm{Cu} \text {, } \\
\mathrm{Cr}, \mathrm{Pb}, \mathrm{Zn} \text { e } \\
\mathrm{Fe} .\end{array}$ & $\begin{array}{l}\text { Enriquecimento } \\
\text { de As e Hg. } \\
\text { Teores dos } \\
\text { demais metais } \\
\text { próximos aos } \\
\text { valores de } \\
\text { background. }\end{array}$ & $\begin{array}{l}\text { Teores de metais } \\
\text { proximos aos } \\
\text { valores de } \\
\text { background. }\end{array}$ & $\begin{array}{l}\text { Teores de metais } \\
\text { próximos aos } \\
\text { valores de } \\
\text { background. }\end{array}$ \\
\hline
\end{tabular}


Principais eventos históricos relacionados ao desenvolvimento urbano-industrial da Baixada Santista e seu reflexo no teor de testemunhos (Adaptado de Fukumoto, 2007). (Continuação)

\begin{tabular}{|c|c|c|c|c|c|c|c|}
\hline \multirow[b]{2}{*}{ Ano } & \multirow[b]{2}{*}{ Evento histórico } & \multicolumn{3}{|c|}{ Fukumoto, 2007} & \multicolumn{3}{|c|}{ Presente trabalho } \\
\hline & & $\begin{array}{l}\text { Largo de Santa } \\
\text { Rita }\end{array}$ & Rio Casqueiro & Largo do Canéu & Santos 1 & Santos 2 & Santos 8 \\
\hline 1920 & $\begin{array}{l}\text { - Inauguração da Usina Henry } \\
\text { Borden }\end{array}$ & $\begin{array}{l}\text { Valores de } \\
\text { background. }\end{array}$ & $\begin{array}{l}\text { Valores de } \\
\text { background. }\end{array}$ & $\begin{array}{c}\mathrm{O} \mathrm{Pb} \text { é o } \\
\text { único metal a } \\
\text { apresentar } \\
\text { teores } \\
\text { superiores } \\
\text { aos do } \\
\text { background. }\end{array}$ & $\begin{array}{l}\text { Valores de } \\
\text { background. }\end{array}$ & $\begin{array}{l}\text { Teores de metais } \\
\text { próximos aos } \\
\text { valores de } \\
\text { background. }\end{array}$ & $\begin{array}{l}\text { Valores de } \\
\text { background. }\end{array}$ \\
\hline 1896 & $\begin{array}{l}\text { - Inauguração do Porto de } \\
\text { Santos } \\
\text { - Atividades industriais restritas } \\
\text { a um curtume (1895) }\end{array}$ & $\begin{array}{l}\text { Valores de } \\
\text { background. }\end{array}$ & $\begin{array}{l}\text { Valores de } \\
\text { background. }\end{array}$ & $\begin{array}{l}\text { Aumento dos } \\
\text { teores de } \mathrm{Cu} \\
\quad \text { e } \mathrm{Pb} \text {. }\end{array}$ & - & $\begin{array}{l}\text { Valores de } \\
\text { background. }\end{array}$ & $\begin{array}{l}\text { Valores de } \\
\text { background. }\end{array}$ \\
\hline 1532 & $\begin{array}{l}\text { - Fundação da Vila de São } \\
\text { Vicente } \\
\text { - Período de ocupação } \\
\text { populacional incipiente }\end{array}$ & - & - & - & - & - & - \\
\hline
\end{tabular}

